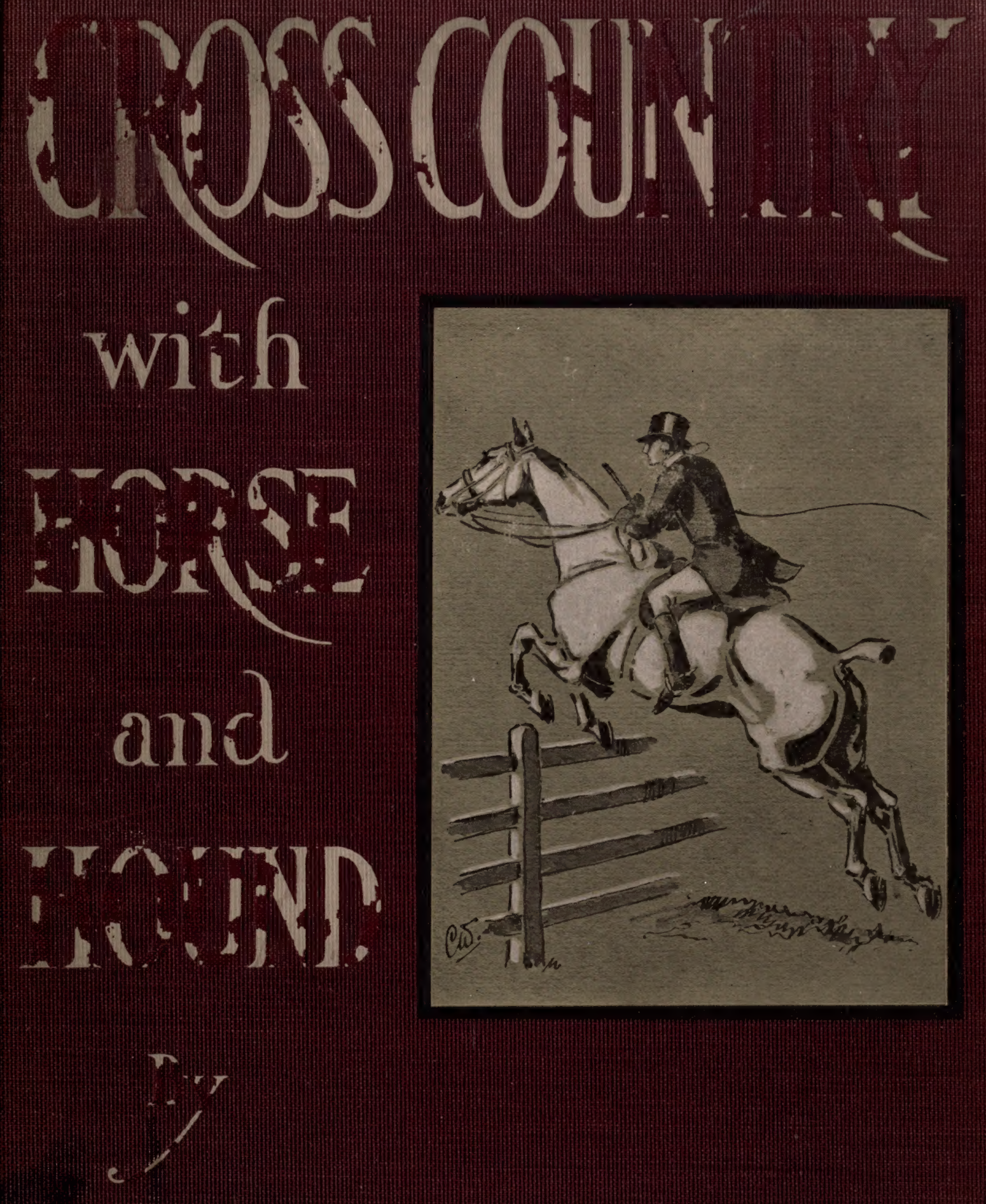

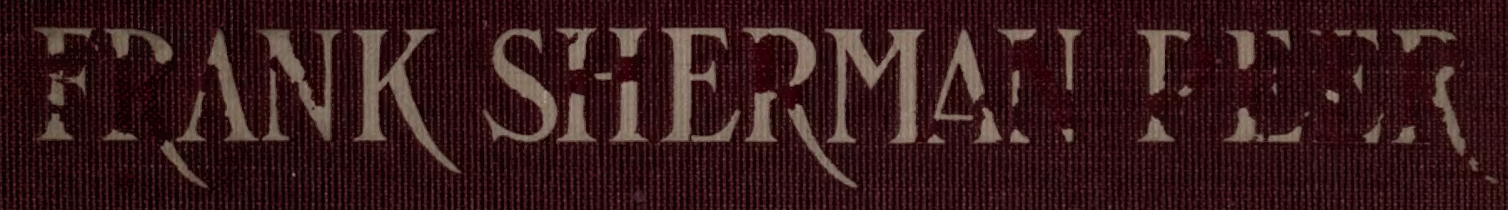





$$
a \times \frac{b}{3} 7^{5}
$$




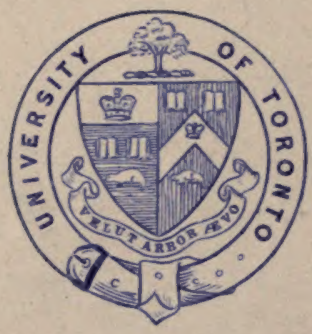

Dresentes to

The Tibrary

of the

University of Toronto

by

Dxecutors of Mrs. Hume Blake 


\section{CROSS COUNTRY}

\section{WITH HORSE AND HOUND}

BY

FRANK SHERMAN PEER

Author of "Soiling, Ensilage, and Stable Construction"

WITH ILLUSTRATIONS BY

J. CRAWFORD WOOD

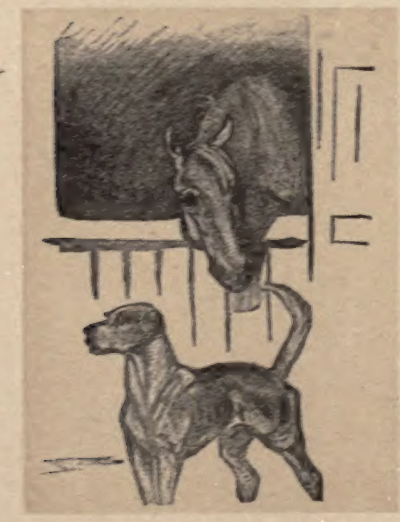

488801

31.3 .49

NEW YORK

CHARLES SCRIBNER'S SONS

1902 


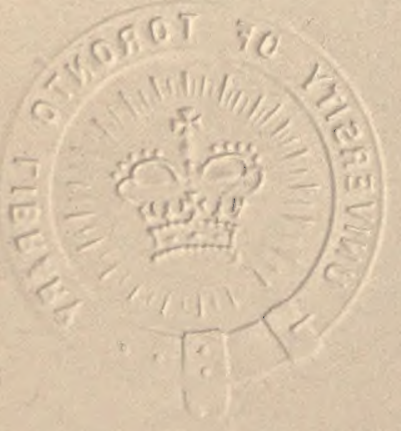

Copyright, 1902, by

Charles Scribner's Sons

Publisbed October, 1902 
TO

THOMAS HITCHCOCK, JR., ESQ.

EX-MASTER OF THE MEADOWBROOK HOUNDS

MASTER OF THE AIKEN (N. C.) HOUNDS

A VERY CLEVER HUNTSMAN

A FINISHED RIDER

A RARE HORSEMAN

A GENUINE SPORTSMAN

THIS WORK IS RESPECTFULLY DEDICATED BY THE AUTHOR 
Digitized by the Internet Archive in 2007 with funding from Microsoft Corporation

http://www.archive.org/details/crosscountrywith00peeruoft 


CROSS COUNTRY

\section{WITH HORSE AND HOUND}






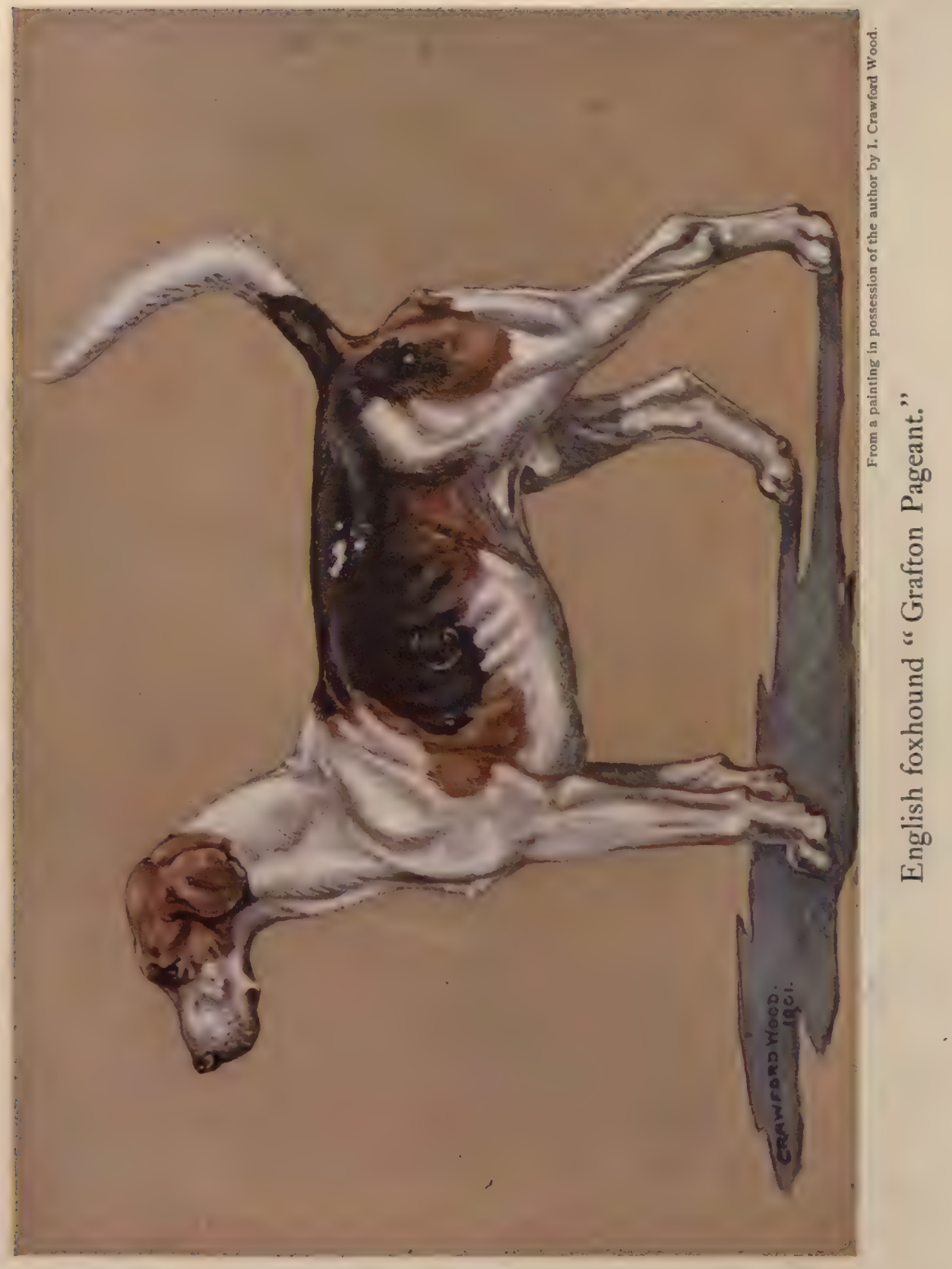




\section{PREFACE}

“ Perhaps, after all, it's a gain in the end

To be tied to the subject you love."

RHYMES IN RED

CTRANGE as it may seem, there never has been a book $\checkmark$ published in America on the subject of cross-country riding to hounds. Let this be the author's apology - if any is required - for presenting this work.

Having moved into a hunting country without previous knowledge of the sport, the author undertook to follow the hounds after witnessing a run from a friend's carriage, and, needless to say, made about as many mistakes as it was possible for a "green un" to accomplish. It was greatly to his mortification and chagrin to discover how much of a sinner he had been against the unwritten laws of the hunting-field - so much so that years later he determined, if an opportunity should present itself, to place in the hands of similar uninitiated ones something in the nature of a guide. Curiously enough, the rules are misunderstood even by a large number of those who follow the hounds. Especially is this true of the men who simply "hunt to ride." Although a gallop across country is a most invigorating pastime, the most interesting and lasting enjoyment, the real sport, comes from a more thorough knowledge 


\section{viii}

\section{Preface}

of the hunt, of the workings of the hounds, the plots laid by the artful Reynard to fool them, and the counter-plots of the clever huntsman. The men who follow hunting year in and year out, through fair weather and foul, through youth, manhood, and age, are invariably the inen who possess this knowledge, and who, instead of simply hunting to ride, are classed with the men who ride to hunt. This work is therefore intended to give the novice an insight into the game from the point of view both of hunting and of riding, so that he may obtain from the sport a full measure of the delights it has to offer.

The author makes no attempt to set up a code for officers of the hunt. He states the conditions and moves of the game from a member's and not from an official's standpoint. He has never occupied any position in the hunt except that of a modest riding member who dearly loved the sport, especially the hunting part of it. His ambition has been to keep in sight of the hounds, and he is quite contented to let the racing men and jealous riders share all the honours they can extract from the satisfaction of being called "first flight men." A more important claim is that he has had considerable experience in breeding, rearing, and schooling hunters that have been for the most part a credit to the system adopted in their training, and has been fortunate in bringing to this work quite extensive observations of many different packs of hounds in European countries, as well as in the United States and Canada. His chief aim is to encourage this most noble sport for sport's sake, to contrast the genuine sportsman with the artificial, and to pay to that noblest of animals, the horse, 
and especially the "hunter," a debt of gratitude for many a glorious hour in his company.

The author is indebted to the artist Mr. J. Crawford Wood for the very lifelike illustrations accompanying these pages. Mr. Wood is one of the keenest hunting men in the famous grass countries of England. He hunts five days a week throughout the season, with such noted packs as the Pytchley, Grafton, and North Warwickshire hounds. Thanks are due also to Mr. Phillpotts Williams, master and huntsman of the Melton harriers, near Salisbury, England, for kind permission to select from his "Rhymes in Red" and his "Poems in Pink" the verses which precede the several chapters of this work. They are so full of the spirit and the true gospel of hunting that they must be heartily welcomed. No author up to the present day has been more generally quoted on all questions concerning the science and art of fox-hunting. No less is the indebtedness to the immortal Somerville, of whose lines the author has made liberal use, although they were written in 1735 and have long been out of print. The odour of the woods and the spirit of the chase live in them still, with the vigour of youth, the colour of autumn, and the freshness of spring.

In a work of this nature it has been found impossible to avoid considerable repetition of thought. Besides, the book has been a long time in pickle. Chapters or portions of chapters have been added at long intervals, and the whole has been compiled during "overtime" from other business - on steam-cars, or at uncomfortable hotels, or on steamships pitched about by winter seas. If it is well received 
it will be in spite of its style. The reins, the gun, and the tiller are probably better suited to the writer's hands than the pen. His chief hope is that the reader may have some of the pleasure in reading the book that the author had in writing it. He is well aware that many of his views are not altogether orthodox, but he has attempted to be honest with himself and present his own ideas and views regardless of some well-grounded notions current among hunting men. We are all apt to get into a rut in our ways of thinking. It may be preferable to have a rut of our own rather than follow a blind ditch simply because the crowd seems to be going that way. The writer is also aware that he now rejects many theories that a few years ago were considered true gospel, which leads him to suspect that a few years hence he may repudiate some things that he now asserts with much assurance. He will consider his reward very ample if in the hour of ultimate success the novice reader has a kindly thought for "Cross Country with Horse and Hound."

\footnotetext{
The Elms

Cornell Heights

Ithaca, N. Y.
} 


\section{CONTENTS}

I True Sport and Sportsmanship • . . . . . I

The word sportsman defined - English and American sportsmen compared - American school and college sports

II Hunting Terms • . . . . . . . . . . . II

A learner's programme - Terms ancient and modern

iII The Hunter: His Conformation

Head - Neck - Shoulders - Back - Loin quarters - Body -

Legs - Disposition

Iv Breeding Hunters . . . . . . . . . .

The best breed - General principles in breeding - Selection of sire and dam - Summary of principles - Treatment of mare and foal

v Schooling Hunters .

The best age to begin - Mouthing and learning to drive -

Schooling for saddle work - Learning to jump, right way Learning to jump, wrong way

vi Buying a Hunter

The horse-dealer and the jockey - Two ways of buying a horse

- How some buyers go about it - The marriage ceremony

vil SeAT

Riding by grip and balance - Bad and good form-How to sit a horse properly - Riding over jumps by balance

vIII Hands

Pullers : how they are made - Proper position of hands - How to hold the reins - Hands when jumping 
ix Jumping Fences, Ditches, and Water . . . II 5 The rider-His management of his horse - Speed at timber and water

$x$ SPurs

Their use and abuse-Relics of barbarism

XI Dress .

The etiquette of the hunting-field - The over-dressed - The under-dressed-The swell

XII Falis

The art of falling - Learning to fall - Barometer of fear-

Falls not the horse's fault

xill Courage vs. Funk

True and false nerve - Cataleptic riders - Preparation - A case of funk that reached collapse

\section{xiv The Hound}

Standard of excellence - Drafting for faults - American and English hounds compared

xv Hound Breeding .

Origin of the breed - Difficulties in the way - The skill of English breeders - Mating and birth

xvi The Hound Puppy at Walk . . . . . . . 177 An important event - Mischievous propensities - Kennel discipline - Cub-hunting

xviI The Fox

The fox compared with other game-Hunting the wild red deer-A pathetic -end - Renard's crafty nature

Xvili The Fox and his Ways

Breeding season - First lessons in craft cunning - What the earth-stopper says - What the farmer and his wife say

\section{Xix Scent .}

Some theories compared - Fondness of hounds for the trail -

Hound music and a novice 


\section{Contents}

xx Farmers and City Men

PAGE

Obligations of hunting men to farmers - Farmers' compensation

and damages - City men in the country - Snobs

xxi The Lady Rider.

Her position in the field - Her horsemanship - Her courage

and resolution - $\mathbf{A}$ famous rider

xxiI Mind-power Horsemanship.

"An indefinable something" - Personal magnetism - Consent

to be governed - Cultivation of mind-power control

XXiII Driving to Hounds. . . . . . . . . . $25 \mathrm{I}$

An interesting pastime - The Doctor and the little mare - A

remarkable spill

Xxiv Officers and Hunt Assistants. . . . . . . $26 \mathrm{I}$

The M.F.H. - The huntsman - The whippers-in - The ken-

nel huntsman - The earth-stopper

xxv Horse Companionship - . . . . . . . 275

Love of animals - Advice to beginners - A long list of "don'ts"

xxvi The Consultation of War . . . . . . . 293

Arranging for a day's hunting - An elaborate preparation -

Old Simpson at work

xxviI The Meet . . . . . . . . . . . 30I

The M.F.H. as host-In discharge of his social duties - Introducing a few friends

xxvini Riding to Covert . . . . . . . . . . 3i I

Mounting for the start - A rider in a fight with his horse -

Mrs. So-and-So and our huntsman - Position

xxix The Game Itself. . . . . . . . . 325

Breaking covert - Full cry - The check - The riders - The death

xxx The Hunt Dinner . . . . . . . . . 339

The huntsman's toast - "To fox-hunting in general" - The

Doctor tells a story 



\section{LIST OF ILLUSTRATIONS}

Facing page

English foxhound "Grafton Pageant" . . . Frontispiece

High-class grade thoroughbred Blue Rock-hunter type

Heavy-weight hunter - ideal Irish type . . . . .

The harness type . . . . . . . . . . . . $\} 28$

The hack type . . . . . . . . . . . . 328

Thoroughbred stallion Barrett, by Bonnie Scotland . . . 30

Rider's centre of gravity, withers, shoulder-blade, true arm, elbow-joint, and girths . . . . . . . . 32

"A rap on the shins that knocks the feeling out of his legs" 66

Rider in correct position - front and back . . . . . . 92

The right and the wrong way of jumping timber . . . 94

The right and the wrong way of landing over timber . $\quad 98$

Hands - correct and incorrect positions . . . . . . I04

Hands in riding . . . . . . . . . . . II4

$\left.\begin{array}{l}\text { Fast at timber, too extended } \\ \text { Slow at timber, hocks well under . } \\ \text {. . . . . . . . . . . . . . . . }\end{array}\right\}$ II 8

"The sharp rowels of a spur ploughing across the loins of a horse". . . . . . . . . . . . . . 126

"There is a knack about falling, as there is about swimming" ${ }^{3} 8$ " "Catch my horse! Here, somebody! I say, there, catch my horse !'”. . . . . . . . . . . 152 
Bloodhound and greyhound, ancestors of the English foxhound . . . . . . . . . . . . I68

The Master's "priceless beauties" . . . . . . . I72

"Delivers them into the aprons of kindly disposed farmers" wives". . . . . . . . . . . . . I74

"Again you may find her sleeping before the boiler-room fire" . . . . . . . . . . . . I82

"But the whipper-in takes after him. "Ware rabbit! Ware rabbit!"”. . . . . . . . . . . I86

"'There he goes, damn him!' cries the deacon of the First Baptist Church" . . . . . . . . . . . . I94

"'The way in which they will afterward fool some silly old goose" ". . . . . . . . . . . . 206

"Hark to Bluebells, hark to Bluebells," cries the huntsman 2 I 6 Canadian seven-eighths thoroughbred lady's hunter . . . 232 "We saw three or four riders go to grass" . . . . . 256 "It is an old move and has worked beautifully on many occasions" . . . . . . . . . . . . . . 264

"Their heads go up, their music ceases. Again they are at a check". . . . . . . . . . 268

"She is turned out on the lawn in front of the house, where the grasses are tenderest and sweetest" . . . . 278 "Not a man on the place knows enough to do my work" . 298 The colt out of old Jane by Devil-to-Pay . . . . . 304 "There were eight of us at it, and seven got in" . . . 318 From scent to view — " Hie, hie, hie, hie!" . . . . . 328 "scBreak him, my beauties, break him!" . . . . . . . 336 
TRUE SPORT AND SPORTSMANSHIP 
" The note of a hound, ever sweet to the ear, Will leave you no feeling of pain;

It drives away sorrow and drives away fear. Just hark at them now as they fly to the cheer

With a crash on the velvety plain."

POEMS IN PINK 


\section{TRUE SPORT AND SPORTSMANSHIP}

THE WORD SPORTSMAN DEFINED - ENGLISH AND AMERICAN SPORTSMEN COMPARED - AMERICAN SCHOOL AND COLLEGE SPORTS

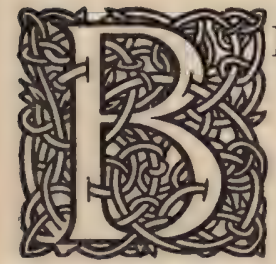

EFORE we consider hunting as a sport, let us come to an understanding as to the meaning of the words sportsman, sporting man, and "sport." In England a sporting man is one who bets on horse-races, follows the " circuit," keeps gamebirds or bulldogs for fighting, or runs a gambling-saloon, and is reckoned in good society as altogether beyond the pale of respectability. On the other hand, to speak of a man as a "sportsman" is to speak of one who is fond of fishing, yachting, shooting, or hunting - hunting in England always meaning riding to hounds, while going for game with a gun is spoken of as shooting. To say of a man in England that he is a good or genuine sportsman means that in all such games of sport he plays fair and is gentlemanly, honourable, and open-handed. He asks no favours and grants none, winning or losing on his personal merits. In short, a genuine sportsman and a genuine gentleman are synonymous terms. We are bound to use the words sport and sportsman very often in the following pages, and in every 


\section{Cross Country with Horse and Hound}

case according to the English usage. In America the term sporting man has much the same significance as it has in England, with an additional suggestion of the cheap "sport" in it, while sportsman is loosely used to mean any one fond of out-of-door sport.

Whatever we say of England as a nation, we must admit that the inhabitants of that country know how to play, and it is for this reason, also, that they know how to live. They have discovered the elixir of youth as has no other nation. We must also admit that they know how to play fair, and that they are the best and most genuine sportsmen anywhere to be found. It is not too much to say that the universal love of field-sports in England is one of the principal causes of her greatness as a nation. Fair play is a cardinal virtue among her people. The lessons the youths of England absorb from cricket, football, rowing, and other outdoor sports of skill and chance have done as much to establish and maintain the supremacy of that little country among the nations of the world as have all her schools, colleges, and churches combined. I recognise that this is a sweeping assertion, and perhaps a difficult one to prove; but I make it with the greatest confidence, after considerable study and observation of the English people. In the first place, their universal love of field-sports has done more than all else to grow healthy men and women. The ambition of an English father is to grow his sons and daughters as he would grow his farm stock - fine, healthy, upstanding animals. "Go out and play," he says. "I want you to grow up to be big stout men and women. Money is no good to a man without a stomach." 


\section{True Sport and Sportsmanship}

Every English boy while at school is obliged to go out and play. It is a part of his education. He carries the love of outdoor sports taught him at the primary schools on to college, and from there into the hunting-field. There are three thousand students at the colleges in Oxford, and I am informed on most reliable authority that over two thousand of that number are daily engaged in some form of field-sport. I have myself seen thirty crews of eight men each rowing in a single race at Oxford. These were the freshmen only, the pick of at least twice that number of freshmen who were in daily practice. In an English college at least ninety per cent. of the men go in for field-sports. The percentage in an American college must be considerably less. In England these field-sports give place to cross-country riding to hounds when the boy becomes a man. The transition is easy, for many of the colleges and some of the large grammar-schools have packs of foot beagles that once or twice a week hunt the hare. It is a fine sight to see a hundred sturdy lads in the chase of "puss" to a pack of twenty or thirty couples of beagles. There is not a university in England, I believe, but has its hunt club, and a goodly number of students keep hunters or polo ponies that do double duty one or two days a week, at polo, fox, or drag. Even if the English boy has missed this training while at school or college, his healthy, sporthardened nerves never undergo a shock when he essays to ride to hounds.

There are in England and Scotland, in a territory little larger than the State of New York, one hundred and thirtyeight packs of hounds. Hunting is the national sport. It 


\section{Cross Country with Horse and Hound}

is a man's game. Thousands of men over fifty years of age are hunting to-day in England; hundreds over sixty years of age, men and women, too, with grey hair, are riding to hounds over some of the roughest country; and scores of them seventy or even eighty years old are at their favourite pastime, the chase of the wild fox or deer. In America, men are too apt to be old at fifty, too likely not to have any time for play, or no time for anything but money-making. It is greatly to be hoped that hunting may become more general, for there are yet too few games and distractions out of doors for men. Athletics is the reigning fad in America. Let one hope American children will develope a permanent love of all manly sport for sport's sake, that they may transmit to their descendants not only cleverness and ability, but robust and healthy bodies.

Next to health, the most desirable quality to cultivate in a boy is courage and strength of nerve, and for this there is no schooling he can possibly have like rough-and-tumble field-sports. Health, courage, nerve, energy, come not from learning how to parse or figure, but from learning how to play; and next to health, strength, courage, energy, nerve, the most desirable quality to be developed in a child is fair dealing. Where or in what form is it possible to imagine a system of schooling that will develope this most estimable trait of character like field-sports? Do I place too high an estimate on the value of play? I hardly think so. What has all this to do with hunting? It is the very foundation of it. The field-sports of the boys at school and college are but the primary tutoring to cross-country riding for the man. 


\section{True Sport and Sportsmanship}

The attainment of health is the most priceless of all things earthly to be attained. Courage and nerve are the outgrowth of health, of the power to govern and to be governed, and of the practical, every-day training in that most Christian-like virtue of the Golden Rule. There is still another characteristic of men who never forget how to play, and that is longevity. Who can estimate the value a man would place, in certain circumstances, upon an extension of time? Ask the millionaire who finds his race run, his bolt shot, at fifty. All the time that is spent in outdoor sports is, I believe, in the numbering of our days, so much clear gain. And when at last age may rob the true sportsman of active participation in the chase, the sight of a horse under saddle, a hound puppy at walk, will send a glow through his veins as the touch of a blacksmith's bellows quickens a smouldering fire. $\mathrm{He}$ is helped on by a cheer that gladdens his declining days as nothing else can. To what do old men most lovingly look back as they near the "mellow"? Not to the greatest sermon, the ablest plea, the most skilful operation, the stroke in business that made a million in a single day: all these things have long since ceased to charm. It is the games and sports of youth and manhood that live to the end. These glow with fervent heat. The blood once thoroughly inculcated by true sport and sportsmanship will gambol healthfully to the end. No man, be he king or peasant, can carry to his grave more agreeable recollections than those of the chase, the gun, or the yacht. These live within him, a well-spring of joy to cheer when all that is earthly fails. Speak to any man of his favourite game of sport or skill, and how pleased he is 


\section{Cross Country with Horse and Hound}

to recall it! How youth comes back in his gestures, his voice, his face, his whole frame, crippled and infirm it may be, but made to play again as he tells the oft-repeated story to his grandchildren of how he finished and won the great hunter point-to-point steeplechase when he was a boy, seventy years ago, by a neck! He will tell you with minutest detail of the great fishing excursions to Canada, the shooting trip to the Adirondacks, his horses, his dogs, his yacht, the run of the hounds. These experiences he retains with ever-increasing clearness until the golden bowl is finally broken. You may go still further back to college days, and note what it is that delights him most - to recall the fact that he won a scholarship or graduated with honours, or the race of his college crew in which he took part. If he is a very old man you may go still further back to the games of his school-days. Ask him how the boys in his day played "two all cat," "pom-pom-pull-away," "yard the sheep," "I spy," or "fox and geese," and you will have a most vivid picture of every move in the game. Speak of music. Is he fond of the opera? Oh, yes! but the sweetest music, the melody that still fills his heart, is the music of the hound in full cry, the lament of the blocks when the mainsail is set, the report of the gun, or the clatter of horses' feet.

Men do not yet know enough how to play in America, and I make this plea to every father and mother - to give their attention to growing well-developed animals. Let them turn squarely about, and teach how to play, and how to play fair. Curtail the child in nothing that will tend to develope him physically. Let book-learning take care 


\section{True Sport and Sportsmanship}

of itself. One cannot develope or cultivate in one's children a safer passion than that for clean outdoor sports. They carry with them no stain that will not easily come off. Though health and strength are much more to be desired than riches, yet one delves and saves and denies himself everything to leave to his children money, and lets the more important question of robust constitutions be taken up by chance and the family physician. May every teacher and college professor become builders of bodies as well as minds, educators of the whole instead of a part. May every school-boy and school-girl, before it is too late, learn how to play, how to take defeat in a true sportsmanlike way, to love all manly and womanly games of sport for sport's sake, and live on to enjoy the fulness of mature years with the happy reflection of a well-spent life in the pursuit of health-giving pleasure and happiness. 

II

HUNTING TERMS 
6s Taught to speak

The proper dialect, with horn and voice

To cheer the busy hound."

SOMERVILLE 


\section{II}

\section{HUNTING TERMS}

A LEARNER'S PROGRAMME - TERMS ANCIENT AND MODERN

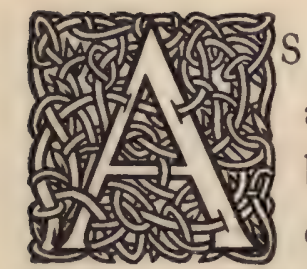

there are many terms used in hunting that are as Greek to the uninitiated, it may not be out of place to devote a few pages to the explanation of them before we proceed further. We shall then feel that our decks have been cleared for action, that our house is in order; or, as my hunting friends might prefer to say, "We are all ready with an early start to follow the line"; we propose to hunt in the following pages.

First, however, let us find a comfortable seat, and spend the evening talking horse and hound and hunting in general. To-morrow morning we will visit the kennels, and then call on "old Simpson," the earth-stopper, and get him to tell us what he knows about foxes. After that we will take a horseback ride, and jump a few fences for practice. In the afternoon we can drive out to see our first fox chase from a carriage. In the evening we will pay our respects to the master and huntsman, and the next morning go early to the "meet," and then " hack to covert." We shall have a sure "find," and no doubt we 


\section{4 Cross Country with Horse and Hound}

shall have a "kill," in which case I hope the reader will be in at the "death," and be rewarded with the "brush," the "mask," or at least a "pad," and be "blooded to hounds" "in due and ancient form." I warn him against cutting corners or being seen at too much road or lane riding. This is a demoralising practice, bad for both horse and rider. Take my advice and stay with the hounds. There was never a run but taught the man of observation something to his advantage. Even a "blank day to hounds" is better than no day at all. Now, then, let us on with it.

Most of these terms are as given by Thomas Smith, Esq., of England in his charming book "Extracts from the Diary of a Huntsman." The volume was published in $183^{8}$, and has long since been out of print. The greater part of his expressions are still in general use all over England and America, with slight modifications and a few corruptions. It is with great pleasure that the author adds to the present work a valuable chapter for those who wish to use and preserve the time-honoured vocabulary of the chase.

Cover hoick - throwing hounds into cover.

Eloo-in - into covert.

Yoi-over - over fence.

*Edawick, Edawick, Edawick - to make hounds draw in cover.

Yoi wind him - encourage hounds to draw.

* Language or sayings marked $*$ have been supplied by the author as additional to the list given by Mr. Smith. 


\section{Hunting Terms}

Yoi rouse him, my boy, or, Rouse him, my beauties - encourage hounds to draw.

Hackles - when the hair on a hound's back stands upright, his hackles are up.

Hoick Rector - cheer to Rector or whichever hound first challenges. (For modern "Hark to Rector.")

Hoick together - when hounds are scattered, to get them together.

Tally-O, or, Tally-O away - when a fox is viewed away. Tally-O back - when fox has returned to covert.

Yo-hote, Yo-hote - when " check" to make hounds hunt. Eloo at him, or, Tally-O at him — when hounds near the fox.

Ware - huntsman's or whipper-in's cry to a hound that is running or doing wrong. "Ware rabbit," "Ware riot," etc.

*Hi! Hil Hi! - cheer to hounds when overtaking their fox. (Fox in view of riders.)

* Babbler - a noisy hound, giving tongue too freely.

*Blank - empty. Covert is drawn blank; i.e., nothing found.

Billet - excrement of the fox.

Burst - of speed. (First dash of speed.)

Burst him - when fox is killed. (Cheer to hounds.)

*Break him - when fox is thrown to hounds.

Burning scent - good.

Breast-high - when scent is so good hounds can carry their heads up.

Carry a good head - good scent and wide enough for the whole pack. 


\section{6 Cross Country with Horse and Hound}

* Cast - the spreading of hounds when in search of the line.

* Challenge - first hound to give tongue.

Counter-when hounds are running opposite to the way the fox is travelling.

Check - hounds stopped.

Chopped a fox - said when fox is killed in covert.

* Cropper - fall from a horse.

Crash, a good crash - when hounds are running in covert and every one is throwing tongue.

Cub - young fox.

Cold hunting - when hounds can hardly " feel scent."

Cover or covert - a wood or any place likely to conceal a fox.

*Crop - hunting-whip.

Down wind - with the wind.

Up wind - against the wind.

*Double - said when a fox runs short back on the line.

Drawing - when hounds are working over a covert.

Drag - scent left by the footsteps of a fox on his way to kennel that morning.

Dwelling — feeling a stale scent.

Drafted - called out.

Earths are drawn - when vixen fox has drawn fresh earth; - proof she intends to lay her cub there.

Flighty - used of a hound that is not steady.

Feeling a scent — said when hounds can hardly distinguish a scent.

*Feather — when hound is waving his "stern" (tail) he is said to be "feathering." 
Foil - used when a fox runs the ground over which he has been hunted before.

Full cry - when whole pack "throw tongue."

Gone to ground - said of a fox when he goes to earth.

Handles a pack - used of a huntsman's management of his pack.

Heel—when hounds run a trail backward. (Running heel.) Hitting it off - finding the line after a check.

Hold hard - warning to a rider to stop or go slower.

Holding scent - when hounds can follow, but not fast.

* Jumping-powder — stimulant taken from a flask.

*Kennel - where a fox sleeps above-ground; his bed; where he was kenneled.

Lifting - when hounds are unable to find and the huntsman takes them on to where he thinks the line is.

* Line hunter - a very methodical and painstaking hound.

Main earths - large breeding burrows or earths.

* Mask - head of a fox.

Mobbing a fox - taking him at a disadvantage.

Mute - hounds run mute when at great speed. (Not giving tongue.)

Opens to the scent, or, Owning a scent — said of hound when he "throws tongue."

Pad - foot of fox.

Riot - when hounds run hare or rabbit. (Compare "Ware riot.")

*Skirter - hound that runs wide of the pack.

Sinking - said when fox shows signs of being overtaken. * Stern - tail of a hound.

Stained - Ground passed over by sheep, etc. 


\section{8 Cross Country with Horse and Hound}

Streaming - hounds running like flock of pigeons. Speaks - when hound owns scent, speaks to it, or gives tongue.

*'Thong - lash of a hunting-crop.

Thrown up - check.

Ticklish scent - one that varies or is uncertain. $*$ Vixen - female fox. 


\section{III}

\section{THE HUNTER: HIS CONFORMATION}


"Be to his faults a little blind, Be to his virtues ever kind."

JOROCKS 


\section{III}

\section{THE HUNTER: HIS CONFORMATION}
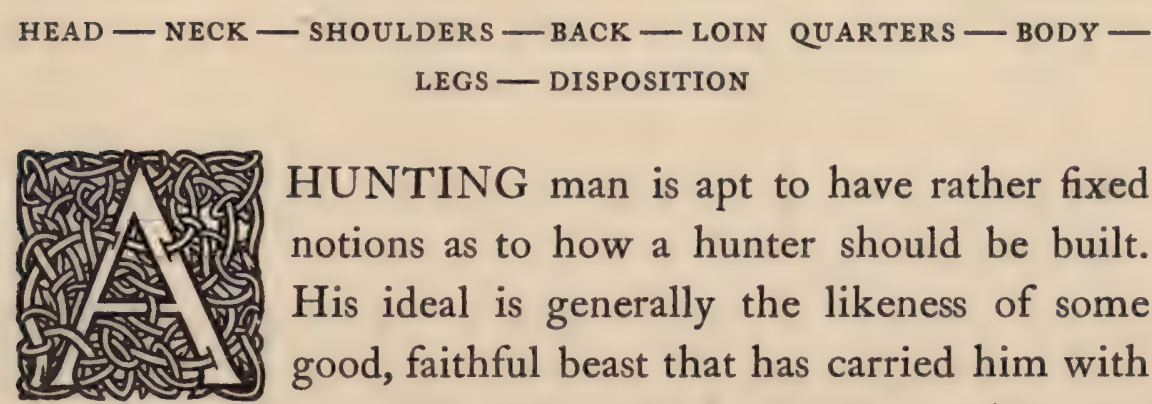

HUNTING man is apt to have rather fixed notions as to how a hunter should be built. His ideal is generally the likeness of some good, faithful beast that has carried him with the greatest ease and safety; which is only another way of saying that a good hunter, whatever he is like, however he is formed, however he is bred, whatever his colour, if he suits and fits us, is not a bad horse.

The one horse among the multitude that have passed through my hands, by which all horses are compared and come short, was one Brunett, a three-quarter-bred Canadian thoroughbred. In conformation she was a collection of minor faults. She was a little over on her knees, slightly sickle-hocked, rather long in the back, had ragged hips, a large plain head, and the longest ears I have ever seen on anything but a mule; nevertheless she was such an animal as one meets with but once in a lifetime. She had courage, spirit, light-heartedness, a happy disposition, rare intelligence, and the most charming manner in harness. 


\section{Cross Country with Horse and Hound}

She was also the most delightful hack that ever carried a saddle. There were bolder-going cross-country horses and faster, but none ever enjoyed the game better; and although she was only fifteen and one half hands, and apparently not up to my weight, I never fathomed her staying qualities. I did not know as much about horses then as I do now, or I never should have parted with her. Take my advice: if you ever come across a horse that thoroughly suits you, let neither love nor money take him from you. The chances are one in a thousand you will ever find another.

But what suits one person will not always suit another. The man to whom I sold Brunett sold her back to me two years later without expressing very deep regret. She went to the Azore Islands for a gentleman's hack, and I have been looking for another Brunett ever since.

The pick of the stable, good, honest, and sound, How eager she was at the note of a hound!

Again, the next best horse I ever owned was, without doubt, the homeliest mare that ever graced the Genesee Valley. She came so near to Brunett in disposition and characteristics that I would have her. She is such a homely horse that no one has ever asked the price of her. She is now twenty-two or twenty-three years old, and has for the last fifteen years been one of the family. Yet, old as she is, none can outshine her, either on a short run or in the lead tandem, where, to this day, she is very proud of herself. A Kentucky negro, seeing her driven into town one day, described her: "She ain't nothin' to look 


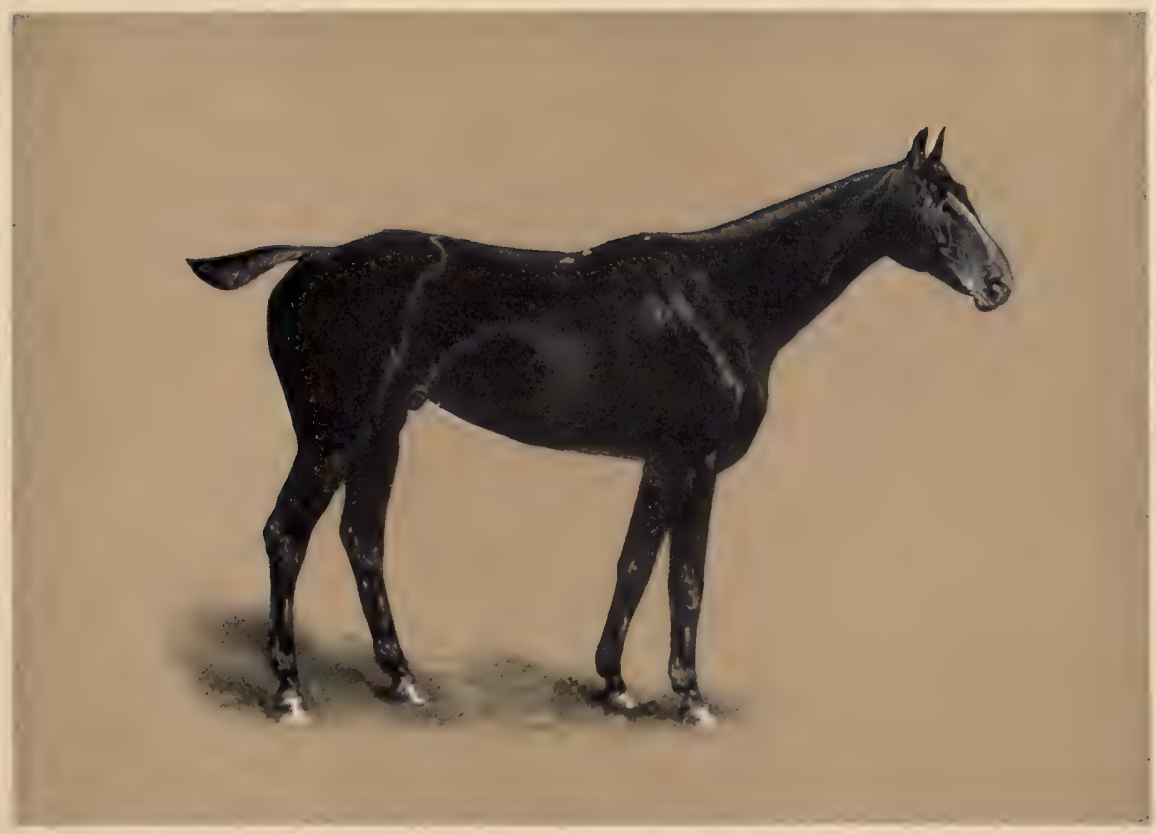

High-class grade thoroughbred Blue Rock-hunter type.

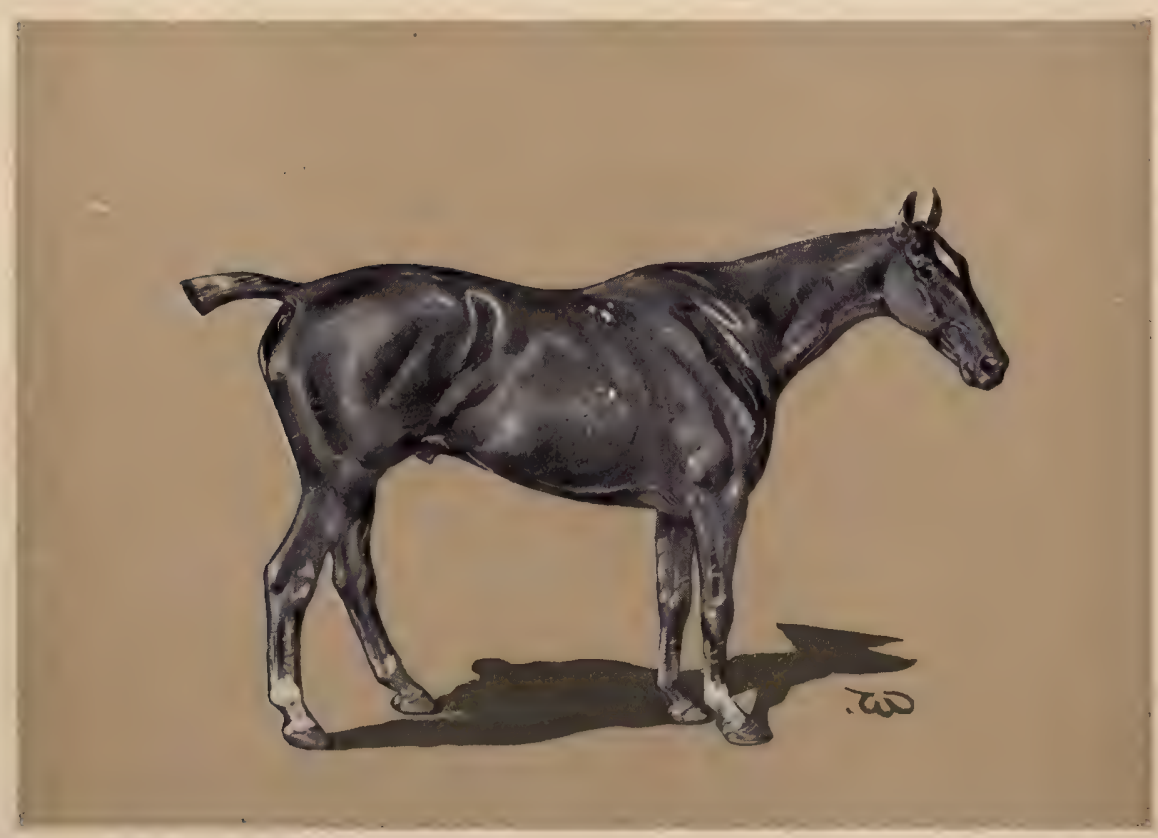

Heavy-weight hunter-ideal Irish type. 

at when she 's a-standin', but she 's a sho-nuff cake-walk mare when she am a-goin'!" Dear old mare! Every one laughs at her, but we love her just the same.

Pardon my digression! The above had to come out somewhere in this book, and it may just as well be first as last. Besides, it illustrates my point: "Handsome is that handsome does." I do not mean to say, of course, that only homely and unshapely horses make the best hunters. Neither of the horses I have just mentioned was an ideal except in manners and way of going, which in a hunter or saddle-horse more than in any other are nearly the sum total of excellence. I mean to say, never discard a horse that displeases you only by his looks. Nevertheless there are some points in the conformation of a hunter that can hardly be ignored. Some general rules, mostly with numerous exceptions, it will be well to keep in mind when passing judgment on a horse for cross-country work.

A large brainy head, with broad forehead and mild outstanding eyes, is, as far as my experience goes, one of the points to insist upon. Some horses with a thimbleful of brains are made to hunt, but without sufficient intelligence to go with judgment as well as courage. One who possesses mere valour can never attain more than a moderate degree of proficiency.

Some fools of horses may be driven through a run, but they do not enjoy it; they are simply slaves. Deliver me from keeping company with such an one in the huntingfield! Hunting is, or should be, a partnership game, in which you and your friend the horse go out for a day's sport. The more intelligent the horse, the more level- 


\section{Cross Country with Horse and Hound}

headed, the more capable he is of entering into the spirit of the game, and of enjoying the day's run as well as his master. It must be remembered, however, that, besides size of brain, quality also is to be looked for. There are big basswood-headed horses, and there are small hickory-headed horses. Quantity must not be confounded with quality. Some brainy horses have from past bad management had their nerves shattered, so to speak, and what brains they have are a damage to them. On this point a study of physiognomy is a help.

There are many rattle-headed, nervous, high-strung horses that make good jumpers, but not every good fencer is, by that same token, a good hunter. Almost anything in the shape of a horse can pull a harrow or go in harness, but for cross-country work a horse must possess the very highest qualities and the sum total of all the virtues of the equine race. He should possess courage that stops just short of recklessness, great nervous force with coolness, great energy with judgment, light-heartedness without foolishness, staying qualities of the best, good breeding, perfect manners. These are the qualifications of a high-class cross-country horse. These are also the qualifications of a high-class cross-country rider. If they are to be omitted from either, the horse should not be the one to suffer, for he has to look out for himself and the rider as well. Besides all this, the horse must have suitable conformation for the work, be a good feeder, and sound.

One can hardly hope to find so many qualifications in a single animal, but if a horse that approaches this standard is found, forgive his shortcomings and be consoled with 
the reflection that if he is not as good as he should be, he might have been worse. Remember this, too, that it is the part of horsemanship to fit the rider to the horse rather than to try to make the horse fit the rider. The greatest and best thing of all is to find in a horse an agreeable companion. A man will get on better with an old farmhorse that fits him than with a two-thousand-dollar qualified hunter that does not.

I have heard some men declare that no horse likes hunting. I am positive this is a mistake. No horse would like hunting with some men, but most horses with the proper conformation for saddle work do enjoy hunting when they are properly ridden. I have seen and schooled many green horses that from weanlings took readily to jumping, and several that when turned into a runway would jump back and forth over the hurdles of their own accord. I have had several green horses that, as soon as mounted, would of their own accord start away to the schoolingground. Of some of these it has been hard to say whether they enjoyed the sport or not until they met hounds, and then they were as ambitious to get on with them as the rider, and not from excitement or fear, as one could tell by the collected way in which they jumped, but from sheer love of the sport. At a check other horses could come and go, but directly hounds moved they were off. I am speaking now of green horses. To some horses hunting is an irksome task that never becomes anything but work or drudgery; yet I believe that a large number of well-bred horses, providing, mind you, they are not punished at their jumps by severe hands or spurs, really enjoy 


\section{Cross Country with Horse and Hound}

the sport. It also goes without saying that there must be a great difference between a horse that has his heart in the sport and goes at it like a school-boy from his books, and one that has only a poor gizzard for the work. I have dwelt on this point because it demonstrates what I wish to bring out farther on in the chapter on "Schooling Hunters."

Horses with short, thick necks do not make good hunters. I do not know of any exception to this rule. They are not easily brought to hand; they invariably rein badly, and are apt to have hard, unyielding mouths. Avoid also a horse that carries a high head. This is another rule without an exception. The head of a hunter is quite high enough when his eyes are on a line with the height of his withers, as in the picture at page 22. This low carriage of a hunter's head is very important, and for several reasons: (I) It enables the rider to lean well forward as his mount begins to spring at a jump (see page 96), and still have room for the horse to throw up his head with freedom in the natural act of jumping, without hitting the rider in the face. This point will be noticed more fully later on. (2) High-headed horses must be ridden with a shorter rein than horses with their necks straight. This is an objectionable feature, because, the longer the reins, the better and easier the control. This will be referred to again in the chapters on "Hands" and "Pulling." (3) When a high-headed horse is ridden at a jump, especially if he pulls and his head comes higher than its natural carriage, the animal is in a most awkward position to take his fence. He does so at the expense of an unnecessary amount of exertion, while 
the rider's control of his mount is gone. (See page 28.) If there is one sight more annoying than another, it is a highheaded horse charging at fences and gazing at the stars. No one likes to put martingales on hunters, and very properly not, for they need absolute freedom of their heads at their jumps.

The position of the horse's head (page 92), when properly held, gives to the hands the greatest length of rein and the best possible control of the mount. Control begins to lessen as the head is raised above this point. That a rather high-headed horse may, by being ridden with a curbbit properly handled, have his head held in its proper place, there is no doubt. What I wish to point out is simply the most natural and best conformation or carriage of a hunter's head and neck, not the method of driving a highheaded harness type of a horse so that he may carry his head as it should be when he is under saddle. Riders who have had their glasses smashed, their hats knocked off, their teeth loosened, trying to make into a hunter a horse good except that he carried his head too high, will be shy in the future of high-headed horses for hunting. This point will be found illustrated at page 28 . While a hunter should be long in the neck, the neck should not be drawn too fine. Horses with very slim necks generally bend them too easily. Nothing is more annoying than a horse that turns only his head in answer to a pull on the reins, while his body goes straight on. One of the worst falls $I$ ever saw in the hunting-field was with just such a horse. Slim Neck wanted to follow the horse in front of him. The rider, seeing that the ground was too 


\section{Cross Country with Horse and Hound}

soft on the landing side, attempted to pull his horse away; but the horse, instead of answering to his hand with a turn of his body, brought his head round until it nearly touched his rider's leg. On went the mount, striking the rail fence breast-high, horse, rider, and fence coming down in a crash. The rider was caught by the fence, and pinned to earth between it and his horse - a sickening sight. Fortunately for the rider, the ground was soft. Beside having an awful shaking up, and the flesh of his legs horribly scraped and bruised, he was left unconscious for several hours. The same thing occurred to a friend of mine, whose horse went slam-bang against a barbed-wire fence because his neck was too weak or too limber to answer to the pull of the rider. The poor beast was horribly mangled and nearly ruined for life.

I have dwelt upon this point because it is one seldom, if ever, mentioned by writers, and because we hear so much nowadays about having "plenty of horse in front of you." So there should be; but look well to the substance of a hunter's neck. "There is ain thing aboot a hunter a canna forgie," said a keen hunting friend of mine in Scotland, "and that is a neck with na starch in it!" The neck can hardly be too long unless too thin; it can hardly be too low unless too short and thick, and of two evils better a horse that bores than a horse that soars. You sometimes see in a dealer's stables these up-headed horses. They are generally clean trotting-bred animals that have had their manes pulled and their tails chopped off, and these are their principal qualifications as hunters. Some of them can jump, and we have seen this sort win at Madison Square 


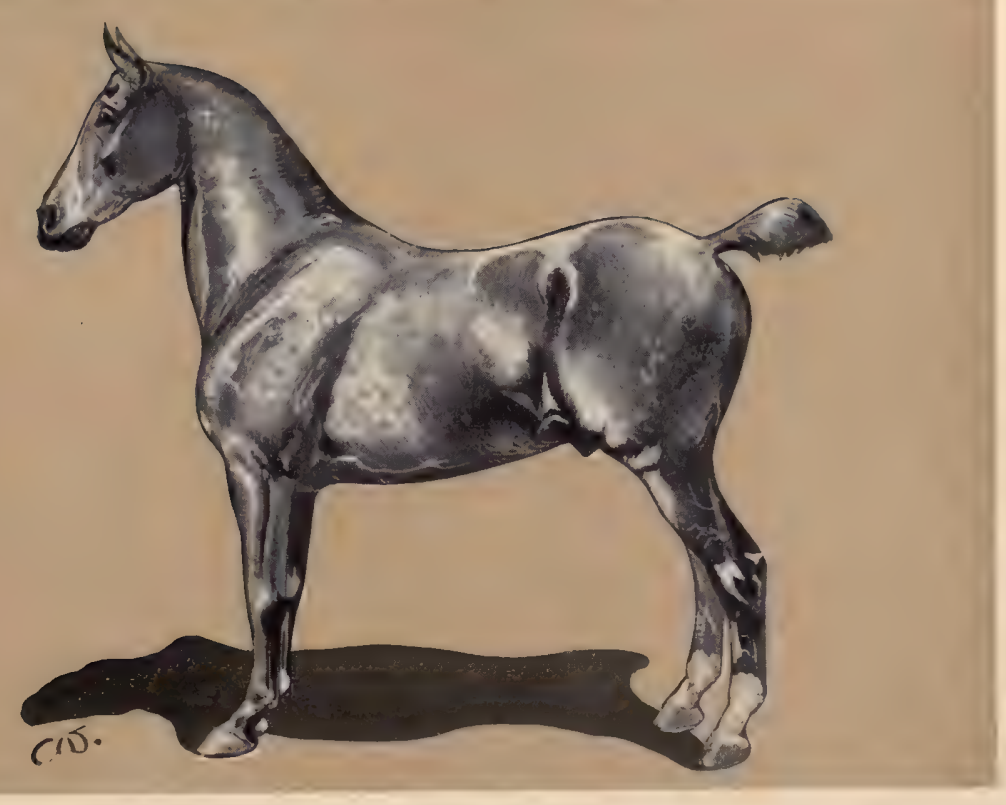

The harness type.

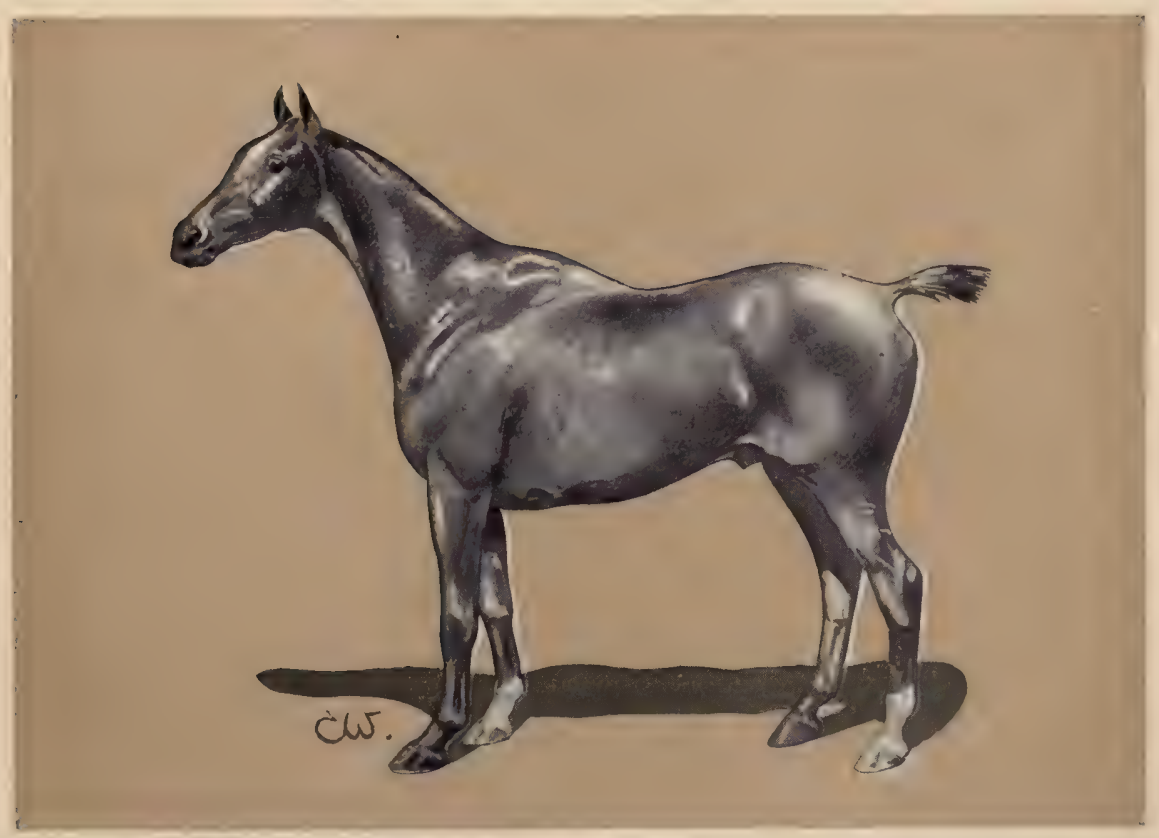

The hack type. 



\section{The Hunter: His Conformation}

when conformation counted fifty or sixty per cent. To an experienced cross-country rider, however, they look sadly out of form.

"Slanting shoulders" is everywhere the cry. Every author I have read, and nearly every man that rides to hounds, if he hardly knows the fetlock from the forelock, will tell you a horse is no good for a hunter without slanting shoulders. So universal has this cry become that it suggests the parrot. "Slanting shoulders! Look at his slanting shoulders!" But when you ask a man why he is so fond of slanting shoulders, the usual answer is: "Well, because a hunter should have slanting shoulders!" Occasionally a man will venture to say a horse with slanting shoulders can gallop faster. This is manifestly incorrect. Some of the fastest horses that have ever turned a track have had rather upright and sometimes even loaded shoulders.

There was the celebrated thoroughbred stallion Barrett, by Bonnie Scotland, that held the three-quarter-mile record (I.I4) for years. He was sent to England by Mr. Pierre Lorillard, with Iroquois, at the time that horse won the Derby, being the owner's favourite for that event, but scratched for uncertain starting at the post. This horse Barrett had not only rather upright but decidedly loaded shoulders. This, indeed, was the characteristic of many of the Bonnie Scotlands, and as a family they were the most celebrated record-breaking runners of their generation. So much for galloping. Through the kindness of $\mathrm{Mr}$. Thomas Hitchcock, Jr., Barrett was sent to Genesee Valley, and for eleven years was at the head of the Squawkie 


\section{Cross Country with Horse and Hound}

Hill Stud for getting hunters. It is safe to say that although most of his descendants were similar in conformation in this respect, no other thoroughbred stallion in America has produced so many high-class cross-country horses as this same stallion Barrett. So much for the jumping. We must look further than simply the slant of a hunter's shoulder. I am sorry to antagonise this most common belief in slanting shoulders; one dislikes to sow seeds of discord among pet theories. But this slantingshoulder craze has gone beyond all reason.

Let us see if we cannot find a better reason than because, or speed, or jumping qualities. Let us see if we cannot set up a hypothesis that will stand more of an assault than the present theories for slanting shoulders. A little reflection will prove that the proper position of a saddle on a horse for cross-country work, where there is jumping to be done, is one that places the rider well back, so that his weight comes as near the centre of gravity as possible. Flat-racing and cross-country riding are things of entirely different colour. The forward seat, over the horse's shoulders, - a seat, in fact, where the position of a jockey lying along the neck of his mount brings the rider's centre of gravity well over, if not forward of, the fore legs of his mount,- - has been demonstrated beyond question to be the very best position under which a horse on the flat can extend himself. Doubtless a horse with the weight on the shoulders makes the lift of the weight with the spring of the fore legs, which leaves the hind legs and quarters to do the propelling with the least possible hindrance. On the other hand, while a horse may be ridden with the centre of grav- 


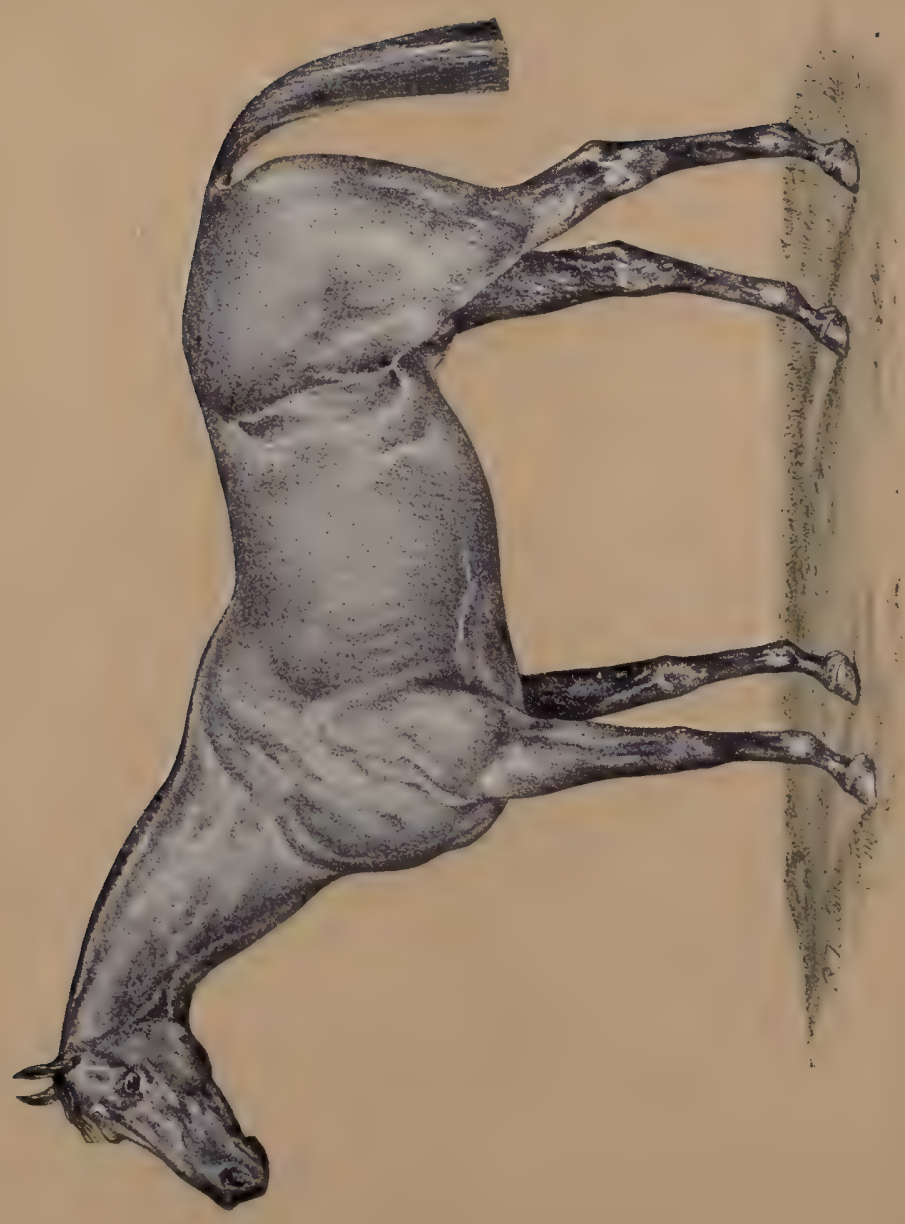

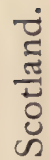

를

ลิ

芯

范 


\section{The Hunter: His Conformation}

ity over his fore legs across a field, it is obvious that in taking a fence the best, the easiest, the most secure position of the rider must be well back. The position of a boy on a rocking-horse, or a person in a rocking-chair, best illustrates my meaning. When the centre of gravity on either the wooden rocking-horse or rocking-chair is forward of the centre, the motion is laboured and all in one direction. If a person sits too far forward in a rocking-chair, the forward rock corresponds to the landing side of a jump, and assists greatly in producing a spill. Seated too far back, one cannot make the rocker go forward without an undue exertion. This illustrates the taking-off position of a jump : the horse, like the person in the rocker, must make an unusual effort to carry the rider forward. This is so plain and simple a condition that it seems almost absurd to mention it. However, it best illustrates the point under discussion. The theory of slanting shoulders is that they usually (but not always) have the effect of keeping the saddle well back, so that the rider does sit nearly at the centre of gravity of his mount. This he is able to maintain, when the horse is jumping, by simply leaning well forward as the animal rises to the obstacle, sitting upright when over the centre, and leaning well back as the animal descends, as illustrated at page 98. So far, I venture to say, the majority of my readers will agree. But, I ask, what is the value of slanting shoulders when, as sometimes happens, a horse is low in the withers, letting the saddle well forward? It is evident that, for keeping the rider back near the centre of gravity, high, sloping withers have quite as much virtue as slanting shoulders, for a horse may have the latter without 


\section{Cross Country with Horse and Hound}

the former. Personally, I prefer a rather straight shoulderblade, with high, full, sloping withers, to the most slanting shoulder-blade with low withers that lets the saddle forward on the shoulders. It is not enough to go strong on slanting shoulders, when it is quite as much a question of the conformation of the withers, and more a question of the setting on of the fore legs. That many men confound withers and shoulders, there can be little doubt; this point is fully illustrated at page 32 . Nor is this all: if a horse, as is quite often the case, has slanting shoulders, and also a long oblique true arm that brings the setting on of the fore legs well back, you have lost at this point all you have gained by the slanting shoulder. In other words, when you have a slanting shoulder with a long oblique true arm, it may bring the fore leg so far back that the centre of gravity has practically been moved ahead. So far, therefore, as gravity is concerned, you might just as well have either a straight shoulder with high, full withers, or a straight shoulder with a short upright and true arm. Or, again, if you have a slanting shoulder with a long oblique true arm, or a slanting shoulder with low withers, the end in view has been defeated. I have dwelt on this at length because slanting shoulders are everywhere so much in favour, as if they were the alpha and omega of a hunter's conformation. At page 32 will be found an illustration (Fig. 3) showing the conformation of an ideal hunter with full, sloping withers that bring the rider well back over the centre of gravity on the upper line; it will be observed, too, from the position where the girth would come, that the fore legs also are properly placed; that is, well forward. 


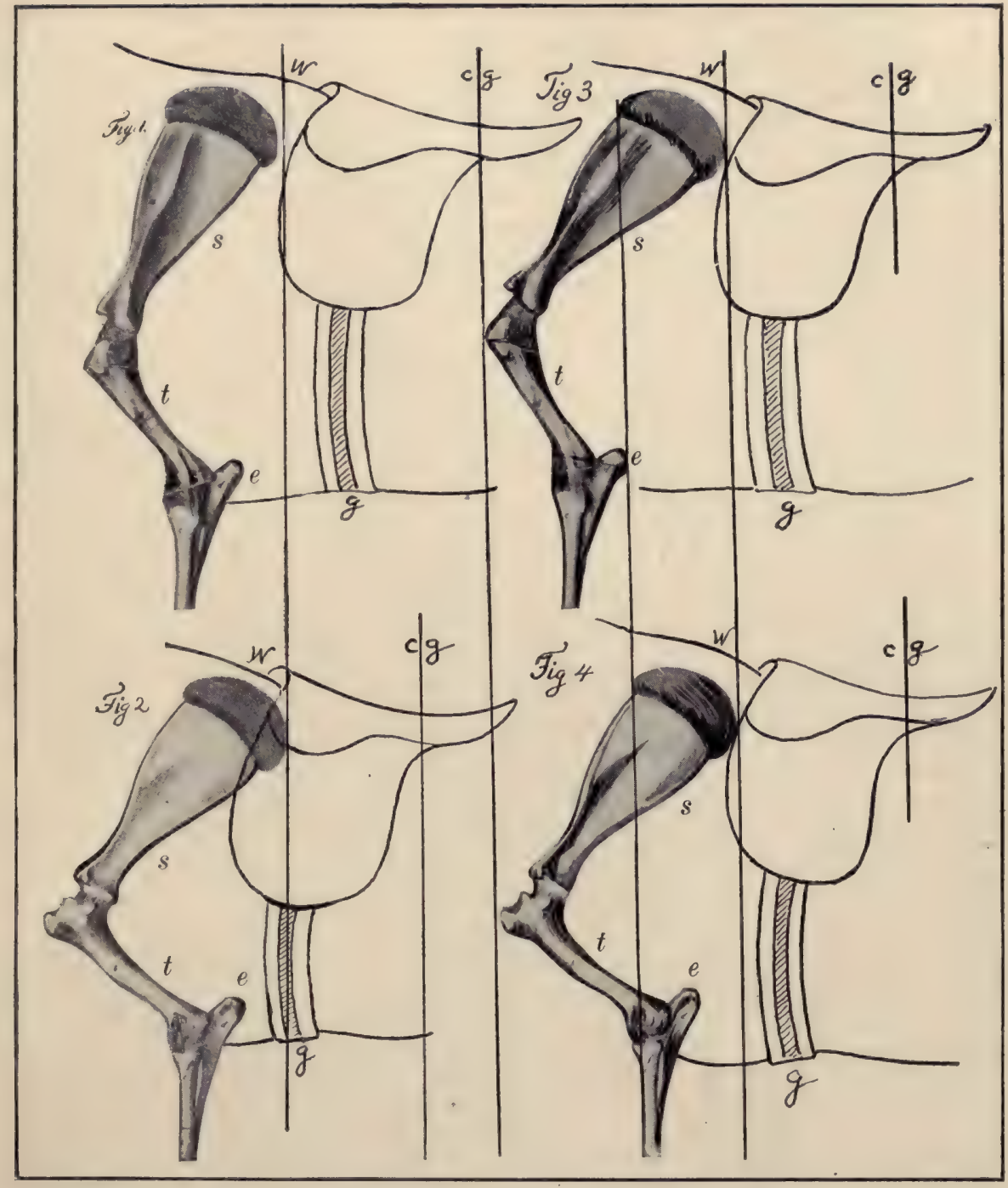

$\epsilon g$, Rider's centre of gravity; $w$, withers; $s$, shoulder-blade; $t$, true arm; $e$, elbow-joint; $g$, girths.

Fig. $I$. Upright shoulder with full sloping withers, keeping saddle and rider well back over horse's centre; $g$, gravity. Fig. 2. Slanting shoulder with low withers, letting rider four or five inches farther forward than in Fig. I.

Fig. 3. Slanting shoulder, full sloping withers with upright true arm, bringing horse's fore leg well forward of girths; best possible conformation for cross-country work.

Fig. 4. Slanting shoulder and full withers, same as Fig. 3, but along oblique true arm, placing the fore legs farther back than in Fig. 3, practically moves rider's centre of gravity forward in spite of slanting shoulder and full withers. 

The reason why ladies in riding cross country to hounds are so uniformly successful in negotiating fences without falls is owing undoubtedly to their sitting sideways on the horse; that is to say, the centre of gravity of the rider is more generally brought over the centre of gravity of the horse than in the case of men, who, riding astride, sit more forward, especially if they ride with long stirrups.

We shall have occasion to refer to this matter again when speaking of "Seat" and "Jumping Fences." The whole thing is summed up: Select a horse with withers running well back and fore legs well forward of the girth; these points secured, the shoulders may be left to take care of themselves. It is doubtful if the mere slant of the shoulder-blades plays any great part in the conformation of a hunter. It must be said, however, that the right sort of withers are more often found in company with slanting shoulders than otherwise.

As for hips, do not turn your back on a horse with rather ragged hips and a sloping rump. They are not pretty or symmetrical, but if they carry the muscle well down to the hocks, you generally find that such a horse can gather his legs well under him for a spring, as shown at page I 8 . This is one of the chief characteristics of the Irish hunter, and for fencing he has no equal.

It is hardly necessary to mention legs, those necessary auxiliaries to a horse. Plenty of bone and especially large knee and hock joints are most desirable. Pasterns on the long side for choice, and plenty of room between elbow-joint and body, are desirable. Do not be over-particular about splints or even curbs. The former are found on three- and 


\section{Cross Country with Horse and Hound}

four-year-olds more often than in horses of six and seven years. They usually disappear by absorption. That a young horse has them is as much to his credit as it is for a child to have the measles or chicken-pox.

Splints, and curbs too, lame a horse sometimes when they first appear. Do not condemn a horse with sickle hocks if there is plenty of bone. They are very often found on the most powerful jumpers.

Do not require a hunter to be too short-coupled. This is another threadbare sign that is always quoted as desirable. If a horse is to gallop he must have length somewhere. If he has a short top line or coupling, he must have length underneath or he cannot stride away. There must be room to get the stifles forward, or you will have a short choppygaited horse, and a most uncomfortable one. The short back is well enough theoretically, but not in practice. Three and even four inches between the last rib and hip are not too much, unless the horse has a weak loin. A light, slack loin is to be avoided in a horse, whether his back be long or short.

A horse is usually as long in the body as he is high from the ground to the top of the withers. In many standard bred trotters and in some thoroughbreds length exceeds height. This proportion is also desirable in a hunter.

A well-formed horse usually measures as far from the top of the withers to the under side of the body just back of the fore legs as he does from that point to the ground. If there is any difference in this measurement, let it be added to the body, not to the legs. A sixteen-and-one: 
body, both in height and length, on fifteen-three legs is far preferable to the reverse.

A hunter, to be comfortable, should not unduly spread the legs of his rider by being too wide through the heart. However, the other extreme is equally bad, for there must be lung capacity; and whatever a horse lacks in breadth through the heart he should make up in depth; the deeper the better. The round-backed and thick-hearted horses so desirable in harness are not to be considered for a moment for saddle work, especially if they have, as is usually the case, low withers. When you have had a saddle turn with you once or twice, you will, like the writer, have learned this lesson by heart. Broad-chested horses are very apt to roll in their gait.

For size, the question depends somewhat on the country to be hunted. A rough country requires a smaller or shorter-legged horse than a country which is flat. My own experience is that a horse from fifteen-two-and-a-half to fifteen-three is invariably the best in jumping and staying qualities. To a man on a horse of sixteen hands the fences do not look so high, but this is of slight advantage when other aspects of the problem are considered. The truth is, there seems to be just about so much force or endurance in a horse, and this lessens as you spread it out over more than the natural size of the family to which the horse belongs. Increased size invariably brings coarseness, putting the animal, so to speak, out of balance with himself.

As to disposition, the best in the world is none too good. A man may have ridden all sorts of horses and first-class 


\section{Cross Country with Horse and Hound}

jumpers, but if he has never found a partner with intelligence enough to enjoy the sport as well as he himself does, he has yet to enjoy one of the principal delights of a day with hounds. Such horses are not plentiful. When a man finds one, he will probably regret it as long as he lives if he parts with him. Out of a hundred hunters you can probably count the genuine sportsmen, the genuine hunters, on the fingers of one hand. In this respect the Irish hunters outclass all others. They are like the people who breed them, always ready for a lark, yet having the keenest instinct for self-preservation. They are light-hearted to a degree, and nothing suits them better than to have a hurlyburly rough-and-tumble scurry across country. They are just reckless and bold enough for such a game, and when mouthed and educated as only Irish hunters are, they will give you a day's hunting to be remembered as long as you live. I have seen them so joyous at the sight of hounds as fairly to squeal with delight, jumping and playing from sheer effervescence of light-heartedness. Such an one is the horse for a companion, the horse for a partner in a day's sport. A genuine sportsman himself, he will pull you through. His heart as well as yours is in the game.

There remains the final test of what may be called "the personal equation." If he fails to pass this, reject him on the spot. You may be surprised to find your supposed ideal hunter not at all to your liking. He does not fit you, and you cannot seem to make yourself fit him. You feel uncomfortable on him, just as you would on a rocking-horse or a rocking-chair that pitched you too freely forward or backward. Seated on a horse that feels comfortable under 


\section{The Hunter: His Conformation}

you in all his paces, you have found the horse for you. Look no further, let size, colour, markings, or conformation be what they may. You will be surprised, in trying twenty fine-looking horses, to find, perhaps, that only four or five seem to fit you. A personal trial is the supreme test of excellence in a hunter. 



\section{IV}

\section{BREEDING HUNTERS}


"The grass in the paddock grows up to her chest, Her tail has grown down to the ground.

There under the oak she is taking her rest; Her beautiful foal, who is one of the best, Flies by with a leap and a bound."

POEMS IN PINK 


\section{BREEDING HUNTERS}

THE BEST BREED - GENERAL PRINCIPLES IN BREEDING - SELECTION OF SIRE AND DAM - SUMMARY OF PRINCIPLES -

TREATMENT OF MARE AND FOAL

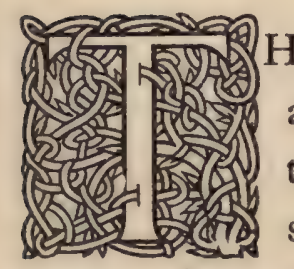

HOROUGHBREDS or thoroughbred grades are the only horses whose general conformation makes them particularly suitable for saddle work. First of all, they are to the manner born, and their gaits, low in action, long in stride, elastic in motion, place them so far above all other breeds of horses for riding purposes that they have no competitors whatever. Long neck and low carriage of head, short upright true arm, great courage, endurance, and superior intelligence qualify them as the breed of all breeds best adapted for cross-country work. Unnumbered generations of careful breeding distinguish them as the aristocracy of the equine race. They have spirit and mettle, and indeed are of such a highly strung nervous temperament that it often requires a bit of horsemanship to get on with them; yet, when a rider once learns to fit himself to their ways and humour their eccentricities, he is spoiled forever afterward for any other breed of horses. Thoroughbreds are not the horses for the uninitiated; they are, as Mr. Thomas 


\section{Cross Country with Horse and Hound}

Hitchcock aptly expresses it, "horsemen's horses." Most men who attempt cross-country riding begin with halfbreeds, and generally end by riding nothing less than seveneighths or clean-bred thoroughbreds.

It is generally believed that in producing half- and threequarter-bred horses the thoroughbred blood should come from the sire's side. Some of the highest class hunters I have ever known, however, have been bred the other way, the sire's side supplying the cold blood.

Blue Rock, a famous hunter and steeplechaser, owned by Mr. William Littauer of the Genesee Valley Hunt,* is out of a clean-bred thoroughbred mare by a trotting-bred stallion. Blue Rock is a plain-looking horse, but his disposition is faultless, and his fencing and speed between the flags and his most perfect performances in jumping contests have won any number of cups and prizes for his owner, who believes he is the best all-round horse that ever lived. The Duke of Beaufort, editor of the Badminton books on sport, says: "I prefer both sire and dam to be well-bred, but a well-bred mare and an underbred horse will produce a faster animal than a thoroughbred horse and an underbred mare."

In a work of this kind there is room for only a few thoughts on the subject of breeding, and we will content ourselves with noting a few fundamentals not found in the usual works on horse-breeding. After fifteen years of experience with a stud consisting of thoroughbreds, hackneys, English and French coach-horses, and thirty years in breeding cattle and sheep, the author may state his belief in a few general rules of breeding. 


\section{Breeding Hunters}

Prepotent sires may generally be relied upon to transmit their conformation or external form, while the dams more generally transmit internal qualities, such as courage, speed, endurance, and vices. The characteristics of prepotent sires, however, are usually more noticeable in their daughters, the sons in this respect generally resembling their dams. Again, prepotent sires are generally found to transmit their own qualities to the second generation through their daughters, while the characteristics of the dams are handed down to the second generation through their sons, as in this simple diagram:

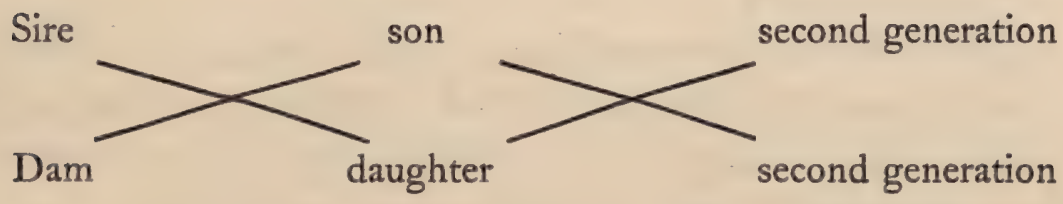

This seems to be nature's way of preserving the balance of power between the sexes. It will be observed that the above refers particularly to prepotent sires. There is little use in attempting to formulate any rules concerning any others. Most rules or theories in regard to breeding are beset with so many exceptions that it is very difficult to establish them.

Of one thing, however, I am thoroughly convinced: that variations or abnormal characteristics are received principally from the dam and are acquired during the period of gestation.

We are always repeating that old maxim, "Like produces like "; yet this cannot be strictly true, else there would never have been variations. All the different families of horses 


\section{Cross Country with Horse and Hound}

are undoubtedly descendants of one common stock. From the Shetland pony of three hundredweight to the mammoth Shire that tips the beam at thirty hundredweight, the pony of Wales, the Clyde of Scotland, the thoroughbred of England, and the trotter of America - all have one common ancestry. It is manifestly inaccurate, therefore, to say like produces like. The saying may be true in a certain degree of animals in a state of nature, but certainly not of animals under domestication. And so far as man is responsible for these variations, we should like to know when and under what circumstances he must act, or does act, to develope them.

These artificial characteristics start in variations which, by careful selecting, breeding, and intelligent feeding, may in time become dominant. When acquired or artificial characteristics become dominant, then they may, under favourable circumstances, be transmittable.

If a colt is better suited for cross-country work than either its sire or its dam or any of its more remote ancestors, a variation or artificial characteristic has been produced. I firmly believe that, whatever degree of excellence an animal ultimately arrives at above that of its ancestors, it receives the impetus from its parents. Subsequent care, feeding, and climatic influences may develope it, but cannot produce it. The time when it is within man's power to assist in the moulding and fashioning of the colt must be prior to its birth.

Confucius taught that the age of a child should begin to be recorded from a year before it was born. It is on this principle, whether it has been recognised or not, that all 
great improvements have been made in domestic animals. Blackwell, Boothe, Bales, the noted short-horn breeders, on this principle developed the great short-horn families of cattle. The dairy breeds of cattle have been evolved by a similar schooling of the unborn calves for the greater production of milk and butter, until they have become as proficient in their way as have the great beef-producing families in the attainment of early maturity and easy fattening qualities.

The standard bred trotter is an offshoot of the thoroughbred. The trotting gait has developed in the offspring a conformation quite different from that of the thoroughbred, one that is better adapted to the purpose. Training may have developed the latent force the animal possessed, but as a spring cannot rise above its source, neither can an animal, after its birth, rise above its inherent character. The treatment of the sire before conception, and especially the treatment of the dam afterward, may elevate it.

Anything you can do toward the education of the colt through his dam, the better. The dam should be turned out as soon as possible after conception, and treated and fed in a way to relax her muscles; yet nothing better can happen to the unborn colt than to have its dam occasionally used in schooling green hunters, say once a week or so. The best and most natural hunters that I ever raised came from mares that had this identical training. The best driving-horse I ever bred came from a mare that was occasionally driven while carrying her foal. While carrying her next colt by the same horse, the mare was never in harness, and the difference in the two colts as they grew 


\section{Cross Country with Horse and Hound}

up was so pronounced as to call my attention particularly to this subject. The first colt was a decided improvement on either sire or dam as to harness or road work, while the second one was barely up to and certainly not beyond them. The third colt by the same horse was a better roadster, but smaller than either the first or second, and I attributed this to my overdoing the matter in my desire to educate the third colt. The mare's muscles were not relaxed enough to give the colt proper room for development, and it never attained the size I believe it would otherwise have reached.

What makes a colt a better roadster than any of its ancestors? What power elevates a foal to a greater degree of proficiency and usefulness in cross-country work than its original stock? I believe it is clearly within the bounds of reason, and to be demonstrated by any one with an opportunity to test it, that it is owing to the imprint of a desire. If the sins of the fathers may be transmitted to the second and third generation, why not the virtues of the mothers? Many mothers have children that are reproductions, not of what they themselves are, but of what they temporarily were in thoughts, moods, and actions. The occasional use of a brood mare for a short cross-country ride during the period of gestation does the mare no harm, and can hardly fail to imprint upon the future generation an influence for good.

My personal observation of this has been so striking that I do not hesitate to say a little schooling of this sort may help the future colt more in the part he is to play in the " noble science" than months of schooling after he is old 
enough to break. He may be expected to know some things intuitively that his mother had to be taught, and to go the right way about them from the first. A variation will have been produced, slight although it may be. In Ireland, in-foal-mares are more often hunted than in any other country, and where in the wide world can one find such natural-born hunters as in the Emerald Isle? I shall have occasion to refer to some practical illustrations of this under the chapter on "Schooling."

To my readers who have never given thought to this particular point in the science of breeding I beg to offer encouragement in it. If they are wanting in faith, let me ask what proofs they have that animals as well as men are not affected for good or ill in embryo? I should advise all such to begin their research by reading the experiments of Jacob and his receipt for producing spotted cattle, and follow this up with the volumes of scientific matter touching heredity. So firmly am I convinced of the great importance of this question that I believe the day will come when the best breeders will recognise it as a fundamental principle in the art of breeding for improvement.

The object most desired in the breeding of hunters is the production of quality plus size. It is no trick at all to turn out small horses with quality. Horses of from fifteen to fifteen and a half hands often have quality to spare. The problem is to be able to obtain sixteen-hand horses and over which have body and bone and substance throughout in proportion to their increased size, and still retain in them the quality of the finer and smaller animals. The general method of selecting as sire the largest stallion that 


\section{Cross Country with Horse and Hound}

can be found, though theoretically sound, in practice seldom results satisfactorily. Size, with coarseness or lack of symmetry, which is still more objectionable, invariably follows the mating of a large stallion with a small or mediumsized mare. Strange as it may seem, size with quality is invariably attained by mating a medium-sized stallion with a large or at least a roomy mare. The reason of this is obvious when we recall the fact that conformation follows the sire. Mere size in colts is more a question of room in the mare, of abundance of nutritious food during the period of gestation, and of a plentiful supply of milk from the dam after the colt is born. Of the two conditions necessary to grow a colt with size,- a roomy mare and feed,the former is perhaps the more important. The disappointment that invariably results for hunting men who breed their best hunting mare to the best stallion they can find comes from not understanding this simple fact.

A mare that is kept constantly at work during the period of gestation is physically incapacitated to produce a sizable foal, owing to having hard, contracted, or unyielding muscles. It is on this account that the first foals of mares accustomed to work are usually inferior in size to the subsequent foals. This should teach us that the mare should be taken from work soon after mating, and treated in every way possible to relax her muscles. At the same time she should be fed liberally on all the succulent food she can eat, with bran and crushed oats added during the latter half of the period. With a medium-sized stallion of the highest quality, and a mare made as roomy as possible, you may rely on feed to produce the necessary variation in size. 
With such a selection for the sire, with such a treatment of the dam, with such liberal feeding of the colt through the dam, it will not be the breeder's fault, to say the least, if the colt is lacking in either size or quality.

The next thing of importance is - after the colt is born - to feed the mare with the one idea of producing a bountiful supply of milk. Although the colt at birth may have latent the qualities one desires, one must remember it still remains for the breeder to see that it has the food necessary to develope that inheritance.

There is one other point I must not fail to mention concerning the selection of a stallion. No sire, no matter what his breeding may be, is worthy of serious consideration unless he is thoroughly and throughout masculine. I have little or no faith in these effeminate stallions which, especially among our standard breds, are so much seen. I should look with suspicion on any stallion " as quiet as a mare," though this, in the estimation of some men, seems to be the sum total of excellence. A stallion, to my mind, should be of such a disposition and strength and courage as would naturally place him at the head of a herd or drove of wild horses. In the breeding of all domestic animals, we should strive to seek such sires as would come to the front by natural selection, that we may work in harmony with nature's law, i.e., "the survival of the fittest."

We shall not attempt now to follow this most interesting question of breeding further. We have only attempted to touch upon such points as practical experience and observation have found running contrary to generally accepted theories, or which are omitted by other writers. 


\section{Cross Country with Horse and Hound}

For the sake of brevity these points may be summarised as follows :

Breed from a clean-bred thoroughbred either on the sire's or dam's side.

Prepotent sires transmit their conformation, or external form and quality.

The dam transmits the internal qualities, such as endurance and the vices and virtues.

All families of horses have a common ancestry.

What an animal is above its original parents, that much it is artificial.

Like does not always produce like.

Variation in domestic animals is principally due to man.

Acquired or artificial characteristics, by selection and breeding and feeding become dominant.

Dominant characteristics become transmittable.

No animal can raise itself above its inherent level.

Variation or improvement in characteristics takes place before birth.

Variations are transmitted principally from the dam, and are acquired during the period of gestation.

The best time to begin the schooling of a hunter is before it is born.

Man's opportunity to breed for improvement ceases at birth. At that moment the die is cast.

A sire of medium size, thoroughly masculine, and of the highest quality throughout, should be chosen; also a dam roomy, or made as much so as possible.

Feed is more potent than breed in producing size.

The best way to feed a colt is through its dam. 


\section{Breeding Hunters}

Our solicitude for the foal before it is born is to produce a variation that will place it above the level of its parents, the better to fit it for the one special purpose in life for which it is intended. We have left to the sire the task of supplying the colt with the quality we desire. It only remains for us to produce size, which, as we have shown, is the result of food and feeding principally.

When the owner can provide succulent food and stables of sufficient warmth, January is the best time for the young hopeful to arrive. If these conditions cannot be fulfilled the colt had better postpone his coming until there is a good bite of grass. In either case, during the season before, if ensilage is not at hand, a patch of roots-carrots or beets - should be provided as a succulent food. During the autumn before, a patch of rye should be sown for a soiling-crop, to be followed by sowings of vetches and pease or oats and pease, so that by fly-time mare and foal may be put in a box during the daytime with a liberal feeding of green forage. Mare and colt should be turned out to pasture during the night only; otherwise one not only feeds the colt through the mare, but myriads of flies through the colt. Mother and offspring will thus be provided with plenty of exercise, and if the stable is properly ventilated, and darkened to exclude the flies, as it should be, you will have surrounded both matron and foal with the very best conditions for the comfort and happiness of the one and the growth of the other.

A feeding of bran with a few crushed oats once a day in the stall will be found the best possible investment. The feed should be in a trough long and low enough to enable 


\section{Cross Country with Horse and Hound}

the foal to join the mother, which it will very soon learn to do. This is also an excellent time to accustom the colt to be handled and later to be introduced to the halter. But this, as Kipling says, "is another story." Young mothers make much better milkers, as a rule, than mares who do not begin breeding until later in life. Whatever the breeder can do he should to assist the mother in producing a plentiful supply of milk. It is from the rich, succulent pastures of Great Britain that the horses and cattle of great size have come. The scanty feed on the Welsh hills and mountains has produced ponies. Whatever you do, provide soiling-crops for your mare and foal.

Feed is the making of breed, but it is the making of breed so far only as to produce variation in size. Variation of characteristics comes, not from food, but from the imprint of a desire.

Flies have robbed more owners of animals that would otherwise have been a credit to them as breeders than any other one thing that can be mentioned. On this account it is better to have the colt come in January or in the autumn, so as to have attained the size and strength necessary to fight for his life, as he is almost required to do during the fly season. What would many of us not give to have a colt out of our favourite hunting mare that should be a credit to the mare? How many thousands have tried and failed? Let the writer's anxiety to point out what he believes to be the cause of such failures, and his kindly interest in hunting men in general and every high-class hunting mare in particular, be his excuse for this overgrown chapter. 
SCHOOLING HUNTERS 
"Nor will it less delight th' attentive sage

'T' observe that instinct which unerring guides

The brutal race, which mimics reason's lore

And oft transcends."

SOMER VILLE 


\section{SCHOOLING HUNTERS}

THE BEST AGE TO BEGIN - MOUTHING AND LEARNING TO DRIVE - SCHOOLING FOR SADDLE WORK - LEARNING TO JUMP, RIGHT WAY - LEARNING TO JUMP, WRONG WAY

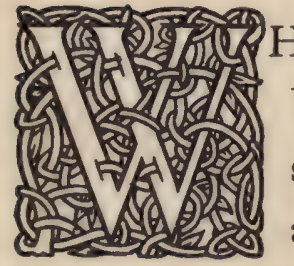

HEN in 1880 I moved into the Genesee Valley and began the breeding, rearing, and schooling of hunters, I was thoroughly green at the business, and had quite as much to learn of the colts and green hunters as they had of me. Twenty-odd years of experience and observation before and after this have produced some very decided notions as to the best methods of schooling as well as breeding hunters. Others, of course, may have succeeded as well as I on entirely different lines, and as to the value of my system must judge for themselves.

We have shown in the previous chapter that a hunter's education should begin before he is born. If the in-foalmare happen to have a foal-at-foot, a most excellent opportunity is offered to give both colts a kindergarten lesson in cross-country work. The foal-at-foot will readily follow its mother over a $\log$ or across a small ditch. Even if at first it goes around the $\log$ and steps carefully down into 


\section{Cross Country with Horse and Hound}

the ditch and out again, it will discover presently that it can more easily jump the log or the ditch than go around. Colts learn with astonishing quickness when they have the example of their mothers before them. The dam going over the obstacle first seems to give the colt the best possible incentive to follow, and an incentive in a colt's head is worth half a dozen stable-boys with half a dozen whips at his heels.

And look at the foal ever close in her wake.

The young one is true to the breed;

He judges his distance and knows how to take

Off, just in the right place, and he lands with a shake

Of his head that shows courage and speed.

It was purely an accident that led me to the adoption of this system. A young horse who was being broken to jump not taking kindly to his fences, an old mare in the field was bridled and saddled to give the novice a lead. The foal-at-foot was put out of sight in the barn-yard, but broke out and joined her mother on the schooling-ground, and, rather than separate them again, was allowed to remain. We thought the foal would run around the wings of the jumps; but she would take no chances of being separated a second time from her dam, and took all the jumps by the mother's side. To make a long story short, the two colts thus educated were the most natural cross-country horses I ever saw. The younger one especially would, as a weanling, jump back and forth over the bars in a runway of her own accord for the sheer love of the sport. This was the chance beginning of a system of training that has been most successful in producing natural jumpers, as well as 


\section{Schooling Hunters}

prize-winners at Madison Square and fairs in western New York.

Whyte-Melville, in his work "Riding Recollections," has something of the same import to say about Irish brood mares. In some counties of Ireland, he relates, the brood mare, with foal-at-foot, is allowed to run wild over extensive districts and leaps in leisurely fashion over stone hedges or mounds of turned-up sod from pasture to pasture, never asking for a gate. Wherever the mother goes the little one dutifully follows, acquiring instinctive courage and sagacity that are afterward to be the admiration of crowded hunting-fields.

Certain general principles of horse-lore the trainer should always bear in mind :

(I) The horse is intellectually the most highly developed and temperamentally the most nervous of domestic animals.

(2) $\mathrm{He}$ is capable of being trained to a very high degree of proficiency in any direction consistent with his environment.

(3) His one great weakness is fear; yet he may come to have such confidence in man that he will perform feats of daring and face danger which under ordinary circumstances he would never attempt.

(4) The secret of successful horse education is the development of confidence, and anything, therefore, that can be done to strengthen or promote confidence may be accounted an aid to his education. Similarly, anything conducive to fear is a hindrance to his schooling.

On these simple fundamental principles "hangs all the 


\section{$5^{8}$ Cross Country with Horse and Hound}

law." It is one thing to break a horse, and another to educate him. Keep in mind the animal's natural timidity, and seek always to overcome this by winning his confidence.

One of the most important things in the training of a horse is mouthing. The universal fault with nearly all American- and Canadian-bred horses is that they have "no mouths," the causes being severe bits, bad hands, and driving begun without a course of " mouthing."

When we consider that all our commands or wishes are communicated to a horse through the lines and the bit in his mouth, the importance of having a horse with a sensitive mouth is apparent; and if this is true of horses in general, what shall be said of the necessity of having sensitive mouths in horses that are to carry us through a run to hounds, where the excitement is little short of a cavalry charge on the field of battle? A person is supposed to ride to hounds for the pleasure it affords. What pleasure can a man derive from sitting on a puller that makes him work his passage from start to finish?

Of all horses, the most objectionable on a hunting-field is first the puller and second the rusher at his fences-generally they are one and the same animal. No horse is quite fit to be ridden to hounds until he can be safely ridden with a common ring-snaffle bit. Most horses' mouths have become so calloused and deadened to feeling by severe usage in breaking them, and by bad, heavy hands afterward, that nothing short of a very severe bit or curb can control them. The first bit put into a colt's mouth had better be a smooth wooden one attached to the halter without reins, or a straight iron one covered with leather. 
One hour is quite long enough for the first lessons. After a week of this preliminary bitting, the "dumm jockey" and slack reins may be added. After this may come the guiding lessons with long driving-reins run through the side-rings of the dumm jockey.

During the first driving lessons the colt should be handled on the barn floor or some other small enclosure. Besides the wooden or smooth iron bit, place in his mouth the loop of a cord, the cord being carried over the head or neck, behind the ears, down through the loops, and on the back through a ring in the dumm jockey. When he is taken outside he will be sure to attempt to run. Now, instead of attempting to restrain him vigorously by the reins, bring him to hand by the use of the cord, which does not affect the part of the mouth you wish to keep sensitive to the bit.

If a colt can be thoroughly broken to drive and ride without impairment of the sensitiveness of his mouth, we have accomplished one of the most important feats connected with horse education. Of course this takes time, and is contrary to the so-called "breaking" system, which invariably ruins the mouth and many times breaks the spirit and heart of a colt before it has accomplished anything toward the animal's education. This question of mouthing a colt is much better understood in England, and especially in Ireland, than in America. We shall notice this subject again in the chapter on "Hands."

After the colt has learned to rein right and left and to back, a sack of bran fastened on behind the dumm jockey for an hour a day is a good thing to accustom him to weight. 


\section{Cross Country with Horse and Hound}

The bran may be substituted by oats, or still heavier grain, for a week or more, before a boy is put up. The colt could no doubt be mounted much sooner; but the slower way is best.

Nine colts out of ten can be thoroughly broken without ever striking them a blow with the whip. If one takes time, it is only in very rare cases that the whip is necessary. When colts or horses set up a fight, throw them carefully. There is nothing that takes the conceit out of a horse like being thrown. Be sure he knows it is you that do it, and that it is by your hand he is liberated. If a colt or horse absolutely refuses to jump a fence, it is usually because of fear, and you should return to lower jumps to restore his confidence in himself. If the fight is one of viciousness and a trial for mastery, take him to the stable and throw him. There is nothing like it. But, whatever you do, never jerk or maul him about.

Always bring a colt on slowly in his lessons, and let the lessons be easy. Never in one lesson ask him to do quite all you know he can, and you will give him the idea that he can do anything you ask him to. You may break a colt by fear, but confidence is the means by which he is educated.

A horse does not reason, but he has a very highly developed instinct. He learns by absorption, which is the result of association. By association, companionship with man, his wonderful instinct is developed to a degree little less effective than reason. He should be convinced that whatever you do is right; that you are his best friend. Never deceive or disappoint him, and you will soon find 
him looking to you, believing in you, and having faith and confidence in all you do and say. Wherein lies our supremacy over these powerful animals? Entirely in their imagination. As long as you can keep their confidence, a silken cord will lead them. Make them mind through fear, and your only safety is in an iron chain.

What if it does take a little time? Think of the time it takes to teach us men some of the simplest things! We do not ask a boy to do fractions until he has had a lot of schooling at easier work. We know that it would discourage him and cause him to lose interest. The same thing happens when we rush a colt on in his lessons. $\mathrm{He}$ is confused and rattled, makes some big mistake, hurts himself, becomes frightened, hates the work, loses confidence, thinks his trainer a fool, falls back on his own judgment, gets a thrashing, fights back, gets another, gives up exhausted, and finally drops to the level of a slave. With no heart, no interest, he shirks all he can, and is sold or dies without regret, all because we were in a hurry. And there is no horse that more requires the slow, methodical training than the colt destined to be a high-class hunter, because, as I have already shown, he must possess so many highclass qualifications.

For jumping, if you are to begin with a weanling, let him find a bar eighteen inches high obstructing his wayone he can with effort step over - when he goes to and from water, or a ditch to jump across when going or returning from pasture - one he can step down into at first. He will soon take to jumping these obstacles as the easiest way of getting over. Do not make any of these jumps anything 


\section{Cross Country with Horse and Hound}

like as high as you know the colt could take. Keep them low at first, so that he will not be flurried.

After a month your weanling will have such perfect confidence that he will begin to acquire knowledge of other things, viz.: how best to gather his hind legs under him before making the spring, and also how to judge the distances. Next winter the same jumps can go a few inches higher. He could jump four feet if you asked him, but do not ask him. Whatever you do, keep the fences low. The thing you wish now to teach is not high jumping, but confidence to gather and take off. After this winter it is quite as well not to ask the colt to jump any more until you begin to ride him, for he may contract bad habits.

I have little faith in the "larking" system. The worst refusers I have ever seen in the hunting-field were horses daily larked as colts until they jumped over six feet. It is one thing for a colt to get himself over a jump, and quite another thing to carry weight over.

During the winter in which he reaches three years old the colt should be bitted or mouthed as described on page 59, taught to rein and back, and be broken to harness. Toward spring he is mounted. The following summer, when three past, his jumping lesson with a rider up begins.

A light snaffle-bit is put on, and he is taken out, in company with an old hunter, over a ditch say two feet deep and a $\log$ two feet high on the way to his exercise, and a little higher across the log and at a deeper place in the ditch coming home. The incentive of returning home gives you this liberty. The colt himself says all this is too easy, but give him two months of it, nevertheless. Make 


\section{Schooling Hunters}

him walk or trot up to all the jumps and drop to a walk immediately after. One desires anything but a rusher in the hunting-field. Horses without confidence in themselves invariably rush their fences. With some horses jumping never becomes more than a sort of neck-or-nothing adventure, and half-schooled horses, nervous horses, and frightened horses rush. Sometimes, too, it is because these conditions, one or all of them, are present in the rider.

Your colt so far has never refused. There comes a trial of your judgment and horsemanship when a friend or a customer rides up just as you are jogging out with slack rein and snaffle-bit for the daily baby jumping exercise, and the temptation assails you to show off your colt. But let your visitor go home thinking you are afraid to put him at anything over three feet. Bide your time.

Next fall, when he is four past, take him up. Early in July have him shod and begin again at the easy jumps, sometimes alone, sometimes in company, with now and then a bit of a canter, slowing down to and after your fences. If you can occasionally take him out with hounds when they are going for exercise, do so. Of course you will always ride him at his fences in a way that puts resolution into the action. You settle down firmly in the saddle, giving him to understand by the pressure of your legs that you are ready. Of course you could go over such a jump without all this, but you must keep in mind his future.

When you settle into the pigskins with a grip of your legs, it says to your colt that you see the obstacle and are prepared to take it with him. You never have deceived 


\section{Cross Country with Horse and Hound}

him. He believes in you thoroughly, and takes a threefoot jump in his stride with as much confidence as he did the eighteen-inch jump when he was a weanling. Up to this time he has never been asked to jump over three feet; but now you take him out, and on the way home you have some new things, say three-feet-six. Nothing like that stops him now. You have jumped him a thousand times, and it always turned out all right. At this point you could take that colt through half a run with hounds, and the chances are he would give many an old qualified hunter a lead over four or even five feet of timber. $\mathrm{He}$ has a nice mouth, and nothing rattles him. He does not worry or pull, knows no such thing as refusing, has absolute confidence in his rider, and can jump, and does jump, anything. The writer has had many falls, but after adopting this method of schooling he never had a horse go down with him but once. An equally good report comes from hunting men in various parts of the country who have had experience with hunters similarly trained.

Whatever a trainer feels obliged to do by way of correcting a youngster or a greenhorn, my advice is, never punish him when he is taking a lesson, especially not when he is in the act of jumping. A colt, if he is whipped or spurred or injured or even made uncomfortable every time he jumps, associates the act of jumping with something that is going to hurt him, and refuses or rushes it, not from fear of the jump, but of the pain he expects to accompany it.

The necessity of having a stable-boy or special rider that has perfect hands and seat and the best of tempers should be noted. It is not too much to say that most faults in 
hunters spring from the bad bringing up, bad hands, bad seat, or bad temper of the trainer.

Such is the right way to school hunters. The method usually adopted - the wrong way - is about as follows:

A promising half- or three-quarter-bred horse four or five years old is bought in Canada. $\mathrm{He}$ has been broken to saddle, but knows nothing about jumping. He arrives at the owner's stable after a day and a night in the train. The same day, or the next at latest, he is turned loose in a runway with the bar at three feet, refuses it, gets a whipping, is chased at it again and again, and finally jumps it. Then he is sent at it again. Over he goes; over again. "Good!" The bar is now put up to three feet six. Over he goes, with a rap on the shins that knocks the feeling out of his legs. "That 's all right. He 'll jump high next time." And so he does. At it again. "Good!" He clears the bar with a foot to spare. "He will make a hunter; no mistake." Up goes the bar to four feet. This last jump rattles the novice. He jumped so high before that he was frightened by the height he found himself at. He begins to tremble, now it is over, at the mere recollection of it. "Send him at it again." After him they go, whip in hand, shouting and yelling enough to frighten an Indian. In this next effort the poor horse loses heart at the last moment, braces his feet, slips, and slides against the bars shoulder-high. The bars fall with a terrible rattle and crash at his feet.

"Put them up again! Don't let him go back to the stable without making him accomplish what you set out to do." At the bars goes Novice again, with a stinging cut 


\section{Cross Country with Horse and Hound}

of the crop. The poor beast is frightened nearly out of his wits. "Now chase after him with your whip. Oh, horror! The fool has no sense." He was going to jump, but lost his head; his heart failed him; took off too soon; struck the top of the bar with such force as to send it flying, while the frightened horse came down on the remaining bars, his fore legs on one side of the jump, his hind legs on the other.

Up go the bars again. A neighbour who has been invited to see "the best horse that ever came out of Canada" is looking on. The owner grows angry. "He has got to jump it now, anyway." Meanwhile the poor horse, with wild eyes and shaking flanks, is nearly paralysed with fear. Thus the punishment, and so-called schooling, goes on. The next day, a boy being put up, with a man to help on, the poor horse jumps simply to escape the punishment. He hates the sight of a runway, and of his master as well.

See him in the hunting-field a month or two later, with wild eyes and restless air. When hounds go away he is as if crazy: rushes his fences; goes on; gets a thrashing for refusing; jumps this fence; expects a thrashing and spurs at the next as a part of the programme, but smashes into it. For this he gets a whack as he lands. He grows worse and worse. His owner can hardly hold him by the curb. At the next fence he takes off too soon, landing on his head on the opposite side, while his rider "goes to grass."

In how likely a condition will this poor brute be to become a good hunter! It is a shame that man has the power so to abuse and ruin the happiness of a dumb brute. 


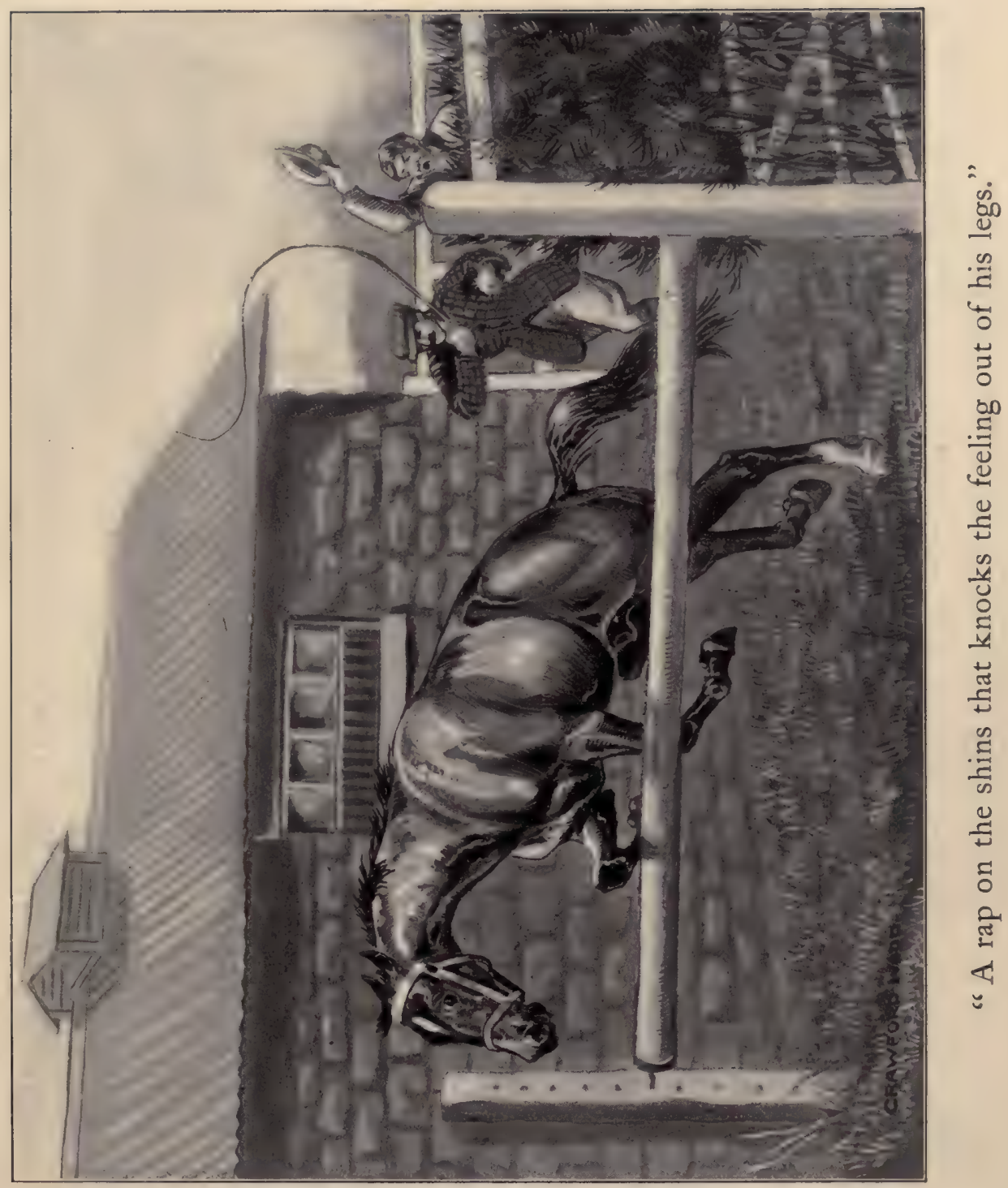





\section{Schooling Hunters}

Does reason say we can ever make a hunter of such a horse? We may make a jumper of him, but between such a horse and the one I previously described there is an impassable gulf. They are not to be mentioned in the same class at all. Look at the two horses going home after a run to hounds - one sad, melancholy, unhappy; the other cheerfully tired, bright, and contented.

Will a horse schooled by the system herein recommended never make a mistake? Certainly he will; but he will not blame his rider for it. $\mathrm{He}$ is as eager to follow the game as the rider is. The other horse would stop at the first fence and go home if he could. In one you have a boon companion, in the other a poor dumb slave. In hunting there is, or should exist, a partnership between rider and horse. The rider should make himself so agreeable to the horse that the horse will never object to the relationship.

A good hunter is one that answers to the hand readily, has a good mouth, does not rush or bolt his fences, and is not flustered at other horses passing or by the sight of hounds. 

VI

BUYING A HUNTER 
"And when you have taken the horse as a friend

Through trouble and care, you 're prepared to defend

Him, as something sent down from above."

RHYMES IN RED

"The very sight of him makes you feel all over like 'unting."

JOROCKS 


\section{BUYING A HUNTER}

THE HORSE-DEALER AND THE JOCKEY - TWO WAYS OF BUYING A HORSE - HOW SOME BUYERS GO ABOUT IT - THE

MARRIAGE CEREMONY

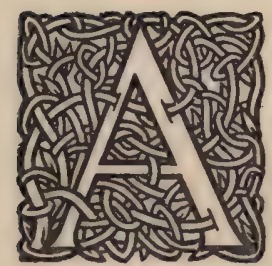

HORSE-DEALER is generally looked upon as a rogue - as if the notion prevailed that a man can be honest and square in every business but that of dealing in horses. When America was new there were what is known as horse-jockeys or horse-traders, a profession nowadays confined mostly to gypsies. It has come about, however, that horse-dealers are, unfortunately, too often confounded with horse-jockeys. I think it is not too much to say that dissatisfaction over horse-dealing is due to the buyer, or his coachman, or a friend, more often than to the dealer. As a matter of fact, the deception is rarely all on the side of the dealer.

Most men go about a horse deal too craftily. They drive up to a dealer's stables with a groom, or a friend, or both.

"Just passing, and thought we would come in and have a look at your horses," they say. (Deception number one: they came on purpose.) "Don't want to buy ; just looking round." (Deception number two.) 


\section{Cross Country with Horse and Hound}

"Perhaps if you saw something to suit, you might buy," says the dealer.

"Oh, no! More horses than I know what to do with. Horses to sell !" (Deception number three : they came on purpose to buy.)

It is amusing to see how many men go about buying a horse in this deceptive way, imagining themselves very bright and clever. They seem to think they have hit upon a new idea of getting the best of the dealer and taking him off his guard. They will buy a horse for two hundred and fifty dollars which, if the dealer knew they wanted it, would cost three hundred dollars or more.

Is the dealer sharp? It is the foolish buyers who make him so. By the time the would-be customer has looked over two or three horses the mask drops and the dealer can read him like a primer.

"What 's the price of this one?" the gentleman asks, with what is intended to be great unconcern. No answer;the dealer wants to confirm himself in his belief that his visitor really intends to buy. The customer repeats the question. The dealer pays no heed, but says: "Come on, gentlemen; I have a promising youngster in this box." The horse the customer has been inquiring the price of is the horse he came to buy; the dealer sees that he has no interest whatever in looking at the promising youngster. $\mathrm{He}$ calls attention to still another horse,- his own hunter, for instance,- one he would not sell. "There, gentlemen, is one of the best horses I own, but I would not recommend any one to buy him." 
The dealer is having a bit of fun. His visitors intended to be smart, and he has to match them.

"Should not advise any one to buy that horse? Why not?" they ask. And he whispers in his customer's ear of this or that trifling fault or defect, until finally he brings his customer round to saying what he ought to have said in the first place:

"What do you ask for the bay?"

"Which bay do you refer to?" asks the dealer, still determined to bring his customer to business. He has dealt with all sorts of horses and colts, - green ones, mild ones, crafty ones, and vicious, - and has never failed to outgeneral and bring them to his own way of thinking without their suspecting how. $\mathrm{He}$ is working the customer in the same fashion.

"The bay in the box."

"Oh!"

Then the dealer turns squarely to the buyer and says: "See here; do you want to buy?"

"Well, that depends upon the price."

"We shall not disagree about that." The truth is, he does not know what to ask, since the groom, up to this time, has not had a chance to tell the dealer how much he wants for himself. "Better see him out first," he adds. "I should like you to mount him."

The horse is taken out and tried, the groom meanwhile making his wants known. "What do you want for that horse?" he asks, sotto voce. "I want four hundred and twenty-five dollars net," is the reply. "Ask five hundred and come down to four seventy-five; see?" 


\section{Gross Country with Horse and Hound}

This is what takes place nearly every day in a dealer's yard. A customer tries to be clever with the dealer, and meets more than his match. The groom has made more out of his employer than the dealer has.

Presently up rides customer number two, the right sort.

"Good morning, dealer. Look here; I am looking for a well-mannered hunter - something you can recommend. I want him for a gentleman."

Out comes the bay again.

"Well, what about this one, dealer?"

And the dealer proceeds to answer without exaggeration. The bay is bred so-and-so; has had three months' schooling; has been ridden several times to hounds; pulls a bit more than the dealer likes, but seems to be coming to his hands nicely. With another month or so of schooling he should make a very good hunter.

" How much?" asks customer number two.

"Four hundred and twenty-five."

The horse is tried, liked, and bought.

When would-be buyer number one learns from buyer number two that he bought his horse for four hundred and twenty-five, he protests. "Oh, confound that dealer! $\mathrm{He}$ tried to sell me that horse this morning for five hundred dollars. I shall never patronise him again. Every horsedealer I ever had anything to do with always tried to get the best of me."

This is one example of the average buyer, the average dealer in horses, and the wrong and the right way to buy a horse. Don't ask a dealer if his horse is sound and then feel for unsoundness. Look him over carefully, if you like, 
and then, if you wish, ask the question. Do not ask the age of a horse and then look into his mouth. Go the other way about it, or keep away from any man whom you would suspect of deceiving you. Go to a dealer who has his reputation to make or keep, and go as straight about the bargain as you would in buying a yard of cloth.

An honest dealer, because his point of view is impersonal, knows better than one's friends what one wants, provided, that is, one tells him just how much of a horseman one is. It may be humiliating, but it is the best and only way. There is hardly a man in the business that will not fit you out in this way with as much care as if you were his own son. If, for any reason, he fails the first time, go back and tell him the difficulty. Most dealers will take an endless amount of pains with such a customer, changing horses until he is suited. Go preferably, if you are a huntsman, to some dealer in a hunting county. Let him give you a mount and ride with you to learn the degree of your horsemanship. If you are not sufficiently advanced in horsemanship to adapt yourself to all sorts and conditions of horses, be sure to try the horse yourself. You may find a thousand-dollar horse so uncomfortable for you that he would give you no pleasure, while another one at half the money would fit you perfectly.

If you must take some one with you, take some professional dealer who knows just what kind of horse you require, agreeing beforehand to pay him a certain commission if you buy. If you are buying of a farmer, beware lest he is ignorant in regard to soundness. He may tell you his unsound horse is sound simply because he does not 


\section{Cross Country with Horse and Hound}

know any better. A dealer, on the other hand, is not likely to buy an unsound horse. The horse you buy from him is, generally speaking, worth all the difference between the farmer's and the dealer's price. There is hardly much advantage in buying of a farmer unless you can give your horse the necessary training yourself. This, indeed, is much the better plan if you can afford time and have skill and taste for the work. A man could hardly have a better training for himself, even, than the personal education of a hunter.

Here is another example of a bargain between a buyer with a confirmed notion that allowances must be made for whatever a dealer says - the buyer, strangely enough, who is always "getting stuck" - and the dealer who can talk horse, one of those fellows whose tongue is operated on ball bearings and has been plentifully lubricated with butter. If a fool is born every minute, these two drew their first breath at the same tick of the clock.

"Can he jump?" asks the buyer.

" Jump! Well, you see that seven-bar stake and rider fence? Well, he jumped that from a standstill when he was a weanling."

"Can he run?"

"Run! Well, I should say! My stable-boy had him down to the track the other day where there are a lot of thoroughbreds in training, and they coaxed him into having a turn. Well, sir, to make a long story short, he left the bunch as if they were standing."

"Has he courage?"

"Courage! Why, bless you, I do believe you can jump 


\section{Buying a Hunter}

him right over a locomotive engine. $\mathrm{He}$ would try a church if you sent him at it."

"Is he sound?"

"Well, now, I want to tell you I have been dealing in horses for the last forty years, and, really, I never owned a sounder horse in all my life."

The buyer here looks for splints and curbs, which is the extent of his ability to judge soundness.

"That 's right," says the seller; " look him all over carefully. Not a scratch or a pimple on him anywhere. If you find one I will give him to you," - etc., without end.

All I have to say is that if a buyer is foolish enough to patronise such men or to be caught by such chaff as this, it serves him right. Buy your own horse. Go alone and tell the truth. That the horse you buy to-day may go lame to-morrow, or take cold on the way home and die in a week, is n't anybody's fault. The buyer took the same chances with the same horse. Don't expect a green-silk umbrella for fifty cents. There are a hundred and one things likely to happen to a horse. Take your share of hard luck when it comes your way as a true sportsman should. In the buying of the best, the soundest, the most perfect-mannered horse in the world, you gamble on how he will turn out in your hands.

A little knowledge is a dangerous thing. Men who have learned a little about horses are invariably conceited. What they know has been picked up by talking horse at the club or reading some one's receipt for "How to Tell a Good Horse." These are among the men who are always getting stuck. Their bumps of conceit usually cost them 


\section{Cross Country with Horse and Hound}

a good bit of money before they develope into real horsesense or knowledge. They remind one of the boy who, when asked how he was getting on in arithmetic, replied: "Oh, I am almost through studying it. I have finished the 'add-ups'; I 'm now in the 'take-froms'; and when I learn to multiply I shall be all through with arithmetic."

Here is another example of a would-be clever buyer of a hunter. This kind writes a letter :

Mr. Horse-dealer,

New York City, April 7, I90I.

Dear Sir: It occurs to me that I should like to inquire if you have any good hunters on hand. I don't know that I want to buy, but if I should I should want a horse fifteen-three hands, bay with black legs and a star in the face. I do not object to one hind foot being white. I like plenty of action, especially knee and hock action; short back with a long stride; high head-carriage without check, and nice long pasterns. He must not be afraid of anything. If you have such a horse I might like to have him, if you would take in exchange one I bought last month of Blank. Please answer by return mail, and greatly oblige

\section{Yours truly,} Richardson Doe.

P.S. Please send photos of the horses you have for me to choose from.

It is amusing to see one of these conceited chaps in a dealer's stables, looking for a curb, picking up a foot,usually only one, on the nigh side, - glaring into the horse's eyes to see if he is blind, appearing very wise after the manner of doctors when they do not know what is the matter with their patient, and asking the dealer: "Is he sound?" Flattered by the dealer's "You can probably judge better than I; I can always tell by the way a man 


\section{Buying a Hunter}

goes about a horse if he is a good judge," - he buys the horse without further question. And how he squeals when he finds he has paid five hundred dollars for a hundreddollar screw. He is deceived again, and the dealer gets the credit for it.

I repeat, I have always noticed that when a man has the courage to tell a dealer he knows nothing about horses, and depends entirely upon what the dealer says, he seldom has much fault to find with what he buys. I remember once when a dealer lost the sale of a horse because a littleknowledge man said he was too straight in the shoulders. The same man bought the same horse a week after from the same dealer, who had done nothing in the meantime but dock the horse's tail and pull his mane!

Speaking of docking reminds me of a laughable horse trade that took place near Passaic, New Jersey. A dealer by the name of Mahoney came to town with a car-load of horses, of which he sold one to a sewing-machine agent. When the dealer arrived in Passaic with his next consignment, the sewing-machine man came back to him declaring that the horse was unsatisfactory, and received about half of the money he had originally paid for him. A few days later his partner bought a horse of the dealer. It was the same horse, only docked. If a dealer is sharp, it is the customer that makes him so.

I have had all things happen to my horses that horseflesh is heir to, but I have never felt that I was cheated purposely by the seller, except once. The idea that dealers go about the country buying unsound, worthless horses, to cobble them up, dope the crazy ones, and whisky the lazy 


\section{Cross Country with Horse and Hound}

ones, is the most absurd notion that ever entered the public mind. Yet people have heard so much of this that they really expect to be cheated, and, if a horse goes wrong in a month, will say they only looked for as much. It is strange what notions some people have. They buy a house that burns down, hire a coachman who developes rheumatism, a footman who gets a sore throat, a servant-girl who gets married, a butler who may die the week after he comes into the house. All this, they say, is providence. But if any of the thousand and one things that are likely to overtake a dumb beast happen within six weeks or two months after he comes into their possession, it is not providence, but the dealer. They are "stuck again."

Tell the dealer just what you want of a horse, and how much experience you have had in riding. Tell the truth, the whole truth, and nothing but the truth. Tell him, even, he may send ten or fifteen dollars to your groom and add the same to your bill. You may think your groom is too honest to accept the fee, but see that he has his tip, or your horse, however good, may never suit, and there will be no end of fault-finding, until you give up in despair and tell the groom to buy the next one himself-which is what he wanted you to do.

Neither should a man boast of his riding or driving to his dealer. He may mislead him into selling him a horseman's horse when he ought to have an amateur's horse. The buyer may find he cannot ride his new purchase: he is a refuser, he pulls, is irritable, will not feed after his run to hounds. Why? Because his rider has no hands; he balances himself by holding hard on his mouth when he jumps. The hunter gets to pulling: the rider gets his reins 
mixed, and pulls on the curb instead of the snaffle. His hunter returns after a run in a state of nervous prostration, breaking out in a cold sweat: his rider does not know that every time he landed he jabbed the spurs into him. From want of horsemanship he took more out of his mount in a single run than he should have done in four or five runs of proper riding. The trouble was, he was " overhorsed." The man who sold the horse, a thorough horseman, may have taken the same horse through a harder run on the best of terms, with sheep twine for reins.

The buyer says he has been deceived; on the contrary, he has deceived the dealer, who sold him what the buyer gave him to understand was wanted. A horse-dealer of any standing is just as eager to suit as the buyer is to be suited. No man in the world knows better than the dealer that confidence and square dealing are his principal stock in trade.-So the buyer goes to the dealer and says:

"You misrepresented that horse to me. You must take him back."

"No," replies the dealer,- or he ought to,-—“ I cannot furnish brains for the horse's mount. And since you put it on the ground that I deceived you knowingly, I will not take the horse back. It would be acknowledging that I had deceived you."

In other words, again the buyer has gone the wrong way about it. If he had gone about it in the right way, truthfully, ten to one the dealer would have fitted him out with a horse of his size - something he could pull and maul; in short, some old stager that would plod through a hunt as through a day's work at the plough.

On the other hand, a horse that will answer for one 


\section{Cross Country with Horse and Hound}

hunting country may be nearly worthless in another. In the Genesee Valley, for instance, where there is plenty of steep hill work with many ravines as steep as a mansard roof, a fifteen and a half to fifteen-three horse is quite tall enough. For the level Meadowbrook country, where they follow the drag, which is only another name for steeplechasing, the nearer the thoroughbred in size that can gallop and fly the fences, the better. Mr. Ellis, the Master there, says: "Take away speed from drag-hunting and there is little left worth going out for."

In selecting a hunter I should rate desirable characteristics in the following order: (I) suitability; (2) pedigree; (3) disposition; (4) manners; (5) education; (6) looks.

Some huntsmen may prefer to put more stress on looks. No one appreciates good looks in a hunter better than the writer, nor do I mean to say good looks are attained only at the expense of utility. Education and manners may be cultivated. Disposition may be improved. Pedigree and suitability are fixed. But the greatest of these is suitability.

From another way of looking at it, buying horses is a good deal like selecting a wife. To impress upon the buyer the responsibility he takes upon himself and the risk he runs in buying a horse, it might be well to have some sort of marriage ceremony. The ceremony might be performed by a Presbyterian, because, for one thing, the buyer ought to endorse the good old doctrine of foreordination.

The ceremony should at least contain the following form: "I, Richardson Gibson Doe, being a man free-born, of lawful age, and desirous of taking unto myself a partner 


\section{Buying a Hunter}

for the chase, do hereby select the bay mare Thistlewhipper for my partner in hunting the wild fox. I do most solemnly promise and swear to take the said bay mare Thistlewhipper for better or for worse, through thick and thin, through sickness, accident, death, or the pink-eye. I do hereby solemnly promise and swear that I will provide the said bay mare Thistlewhipper with a good home, feed, and care, and at all times and under all circumstances treat her as I should wish her to treat me if I were a horse and she were my owner. So help me John Rogers."

Here the buyer, in token of his sincerity, shall disengage his right hand from the mare's forelock and kiss the currycomb or the brush, as he may elect. Then shall the buyer face the seller and say: "Let me pay." And the seller may say: "Let me offer you a glass of cider."

Then shall the buyer hand to his stud-groom or coachman a gold ring, or the price of one, wherewith to ensure the mare from all accidents and disorders, barring blind staggers, until it is necessary that another should be bought. Here endeth the ceremony, and the buyer may now go forth and proclaim to all his friends what a great bargain he hath secured in the bay mare Thistlewhipper. 


\section{VII}

SEAT 
"A chosen few

Alone the sport enjoy, nor droop beneath Their pleasing toils."

SOMERVILLE 


\section{VII}

SEAT

RIDING BY GRIP AND BALANCE - GOOD AND BAD FORM - HOW TO SIT A HORSE PROPERLY — RIDING OVER

JUMPS BY BALANCE

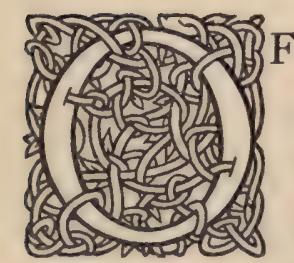

the qualifications that go to make a good rider, seat is of fundamental importance. Hands, ease, grace, correct position, safety, horsemanship - all depend upon seat. When the seat is perfect, and only then, can these things be perfect too. A rider need not expect to distinguish himself beyond his ability, good, bad, or indifferent, to sit his horse.

The perfect seat is the one which gives a rider the best hold in the saddle, with the least fatigue. There are two styles of riding. One depends upon balance, and the other upon grip of knees and thighs, or of calves, to maintain equilibrium.

Englishmen as a rule ride by grip, Americans by balance. The most graceful and finished riders are without question those who ride by balance. Some writers contend that the securest seat is a combination of grip and balance, but I fail to see the force of the argument. 


\section{Cross Country with Horse and Hound}

Riding-school masters - who in America are mostly Englishmen - teach the grip method, and it is owing to them that people are falling into English ways of riding in America,- especially in cities, - which is much to be deplored. Grip, however slight, robs the figure of that suppleness and elasticity of motion and grace of carriage that are characteristic of riding by balance. I regret to say that no one up to the present time has, to my knowledge, come forward outright to champion riding by balance. The tradition of riding by grip has probably been handed down to Englishmen from earliest history, and is only another of many customs that hang on long after they ought to be discarded.

If there is any one thing about riding horseback that I feel more positive about than another, it is that riding by balance is the only correct way, the safest, the most secure, and the most graceful way to sit a horse. This will shock many of my English and not a few of my American riding-school friends who look upon themselves as good riders. But so far as sticking on a horse is concerned, their ability is lessened, as I shall attempt to show, by the very means which they believe gives them security.

First let me call attention to the fact that there resides in every man a certain power or instinctive ability operating under what is sometimes called the first law of nature, or the law of self-preservation. It acts usually independently of the mind, and its processes are much keener and quicker than merely mental processes. When a man rises to walk, for instance, the act of rising is done with a more or less conscious mental effort. Once on his feet, he 
walks on without further thought. Something in him takes his body in hand and keeps it upright and balanced without mental exertion.

Now two thirds or rather more of the weight of a man's body is above the hips. He is really a more or less top-heavy animal. His base - that is, when he is walking or standing, his feet - is comparatively small; it is, too, smaller and farther below his centre of gravity when he is upright than when he is seated in a chair or in the saddle. When he walks his arms swing naturally at his side as an assistance to the maintenance of equilibrium. If he attempts to hold his hands against his sides - an action analogous to holding his legs against the saddle - it requires an effort of mind and destroys all ease and grace of body. I hold that it is no more essential to sit a horse by grip than it is to grip something with the hands when walking. One can as well learn to sit a horse by balance as to walk by balance.

The sooner in life this is learned, the better. All writers advise one to begin young by riding bareback on a pony, and this is quite right, but not because it teaches to hold on by grip. The result is the very reverse: it teaches one to ride by balance, and will, if it is not spoiled by ridingschool training later, produce a perfect seat. That Americans as a rule have most graceful seats is due to their riding by balance, in which they are mostly self-taught, beginning as farm-lads riding work-horses to and from pasture barebacked.

Only a short time ago I was discussing this question with a well-known rider of the Radnor Hunt, near Philadelphia. 


\section{Cross Country with Horse and Hound}

In answer to my advice to ride more by balance, he replied that his riding-school master had always told him what he most lacked was grip. His experience was only that of thousands who attempt to keep upright by grip, coming home after a ride to lie awake half the night with cramps and pains in their legs, the result of distinct and laboured effort throughout the ride.

Compare riding, for a moment, with fencing. When one accomplished swordsman meets another, this is what happens: his mind directs him to place himself on guard before his opponent; but from the instant foil-play begins, mind and reason are a blank. The law of self-preservation takes entire control of the body, directing every action. The man who tries to fence or control his foil by dictates of mind is altogether too slow in self-defence. Reason is useful and necessary to teach position and proper form, but useless in a bout for honours. No man can become an accomplished swordsman or boxer who does not give himself up to this law in self-defence. For the same reason, no one, I believe, can ever become a thoroughly accomplished rider who does not abandon all attempt to stick on by conscious and deliberate grip.

The argument for the security of the seat by grip is weakened by the fact that thousands of men all over the United States are daily riding by balance. The self-taught ranchmen and cow-boys on the Western plains, the American Indians, and hundreds of the best amateur riders all over the country ride by balance.

I remember once complimenting a most finished rider on his seat. "Why, certainly I ride by balance," he re- 
marked, as if no other way had ever occurred to him. "Would you have a person ride with one hand hanging on to the pommel of the saddle? Gripping with both legs against the flaps of the saddle amounts to the same thing."

Riding by however slight a grip has neither theory nor practical results to recommend it ; and it is passing strange that hardly a riding-school teacher and no writer that I have ever found sees the matter in this light. WhyteMelville, in his "Riding Recollections," advocates a combination of grip and balance. To depend upon balance, he says, " is to come home with a dirty coat ; to cling wholly to grip is to court as much fatigue in a day as should serve for a week." On another page, however, he spoils his argument by saying, apropos of grace, that "the loose and easy seat that serves to sway carelessly with every motion, yet can tighten itself by instinct to the compression of a vice, - the prettiest riders, as they say in Ireland, - are probably the ones whom a kicker or a bush-jumper would find most difficult to dislodge."

It is a pity to see the naturally secure and graceful seat of a self-taught American ruined by his going to ridingschool. A person may be longer learning to sit a horse by balance than to hold on by grip, but if he gives himself up to riding by balance, which is only another way of saying gives his body up to the care of the law of self-preservation, he has eventually every advantage in point of security or safety of seat over the man who is holding on by conscious grip. When a person rides by balance, this law of selfpreservation, many times quicker than thought, looks after him just as it does when he is on his feet and walking. 


\section{Cross Country with Horse and Hound}

The instant he is the least out of balance, a muscle contracts here or lengthens there, independently of mental effort, to put his body back on its centre. See two men riding at a fence, one by balance, one by grip. At the last instant the horse suddenly refuses. What happens? The law of self-preservation keeps the one man in his seat, while the other, riding by an effort of the mind, instantly his grip is loosened, goes to grass.

Should we never grip a horse with our legs? Yes, certainly - if the law of self-preservation dictates it. The trouble is, we are afraid in the beginning to trust ourselves to this law.

My advice to a beginner is, if he is a boy, to begin riding bareback on a pony. If a man, he had better have the aid of a pair of stirrups and begin practising by riding at a walk, with his feet as free of the irons as possible. Let him keep at this until he can trust himself bareback on a quiet horse, and then, still at bareback, work away until he can sit a horse at a trot, a canter, and at last jumping over low obstacles. If he does enough of this he will come out a finished rider. It may seem slow and laborious, but it is the shortest cut to the attainment of a perfect seat. If a person is a bit rusty at riding, nothing is better for him than riding bareback for an hour, or, if this is not convenient, riding to covert, say, with the feet out of, or independently of, the stirrup-irons.

While a self-taught rider then invariably rides by balance and is thus master of the one qualification that can make him perfect in all respects, he may yet have acquired bad form. For instance, he may ride with his elbows as high 


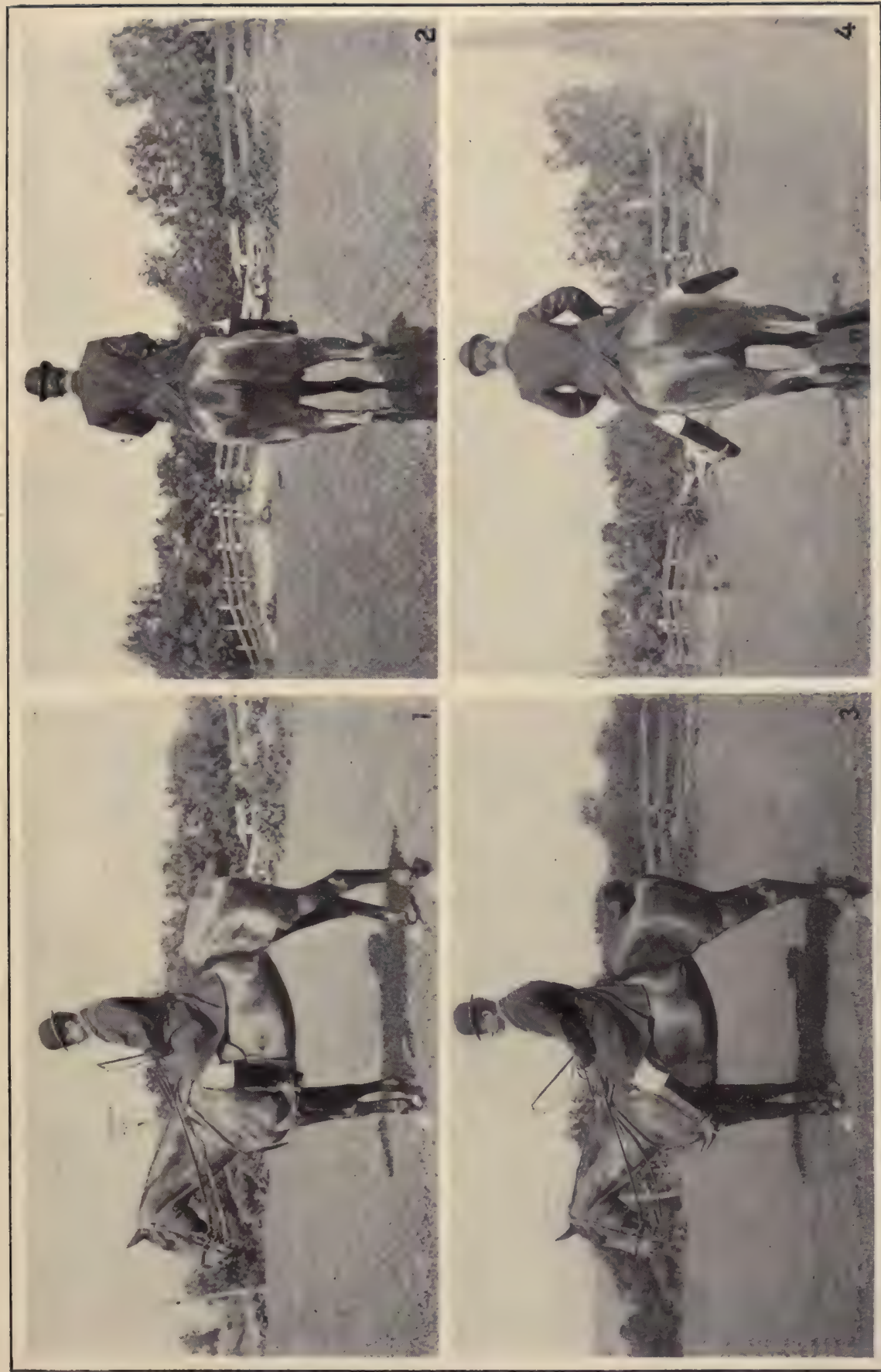

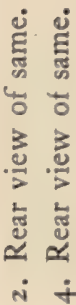

சु

लำ

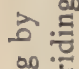

I

․․․

हึँ

岕

$\therefore \dot{m}$ 

as his shoulders and present the ridiculous appearance of working his arms as if he were a flying-machine or a pinioned duck going through the motions of flight. Again, he may thrust his foot too far forward, as if bracing himself against the rush of the wind, or too far back, as if he were trying vainly to get upon his knees. He may slouch in the body too far forward, as if he were weak in the back, or he may sit so straight and stiff as to suggest his being inspired with the idea that he is some great general about to be cast in bronze for a public park. By riding with too long stirrup-irons he may resemble a scarecrow in a corn-field, or by having them needlessly short suggest a monkey riding on a circus horse. Correct form is that which gives the figure the greatest ease and grace of carriage at the same time with the securest seat and least fatigue. Ease, graceful carriage, absence of fatigue, come from unconsciousness. The combination must be natural. Bad form with unconsciousness is better than a position which is forced or unnatural.*

The easiest and most graceful position for the arms is with the elbows hanging naturally against the sides, the upper arm and the forearm at right angles to each other. The hands should nearly meet in front of the body just above the lap, and just high enough to clear the pommel of the saddle, held naturally with thumbs uppermost, and far enough in front of the body to permit free action of the wrists in taking and giving to the natural backward and forward oscillation of the bit when the horse is in motion.

The length of stirrup-leathers is a question much discussed. The straight leg - the forked or military seat - 


\section{Cross Country with Horse and Hound}

may be and probably is best for the most efficient handling of a sabre, but no such position is necessary in riding across country. The requirements in the hunting-field are of another sort. For taking a fence the length of the stirrup-leathers should enable a rider standing in his stirrups just to clear the pommel easily with his crotch,- - which may be necessary when the horse is in the act of jumping, - and to sit well back in his saddle as the horse makes the descent. The shifting of the centre of-gravity of the rider's body, forward during the upward spring, and well back on the descent, cannot be accomplished with long stirrup-leathers. The military seat, with long stirrupleathers, has no place in the hunting-field, where there is jumping to be done. We shall notice this more fully when we speak of riding by balance over fences.

The best position of the legs, as of the arms, is that which is most natural and at the same time gives the stirrup-leathers length in which to alter a rider's position forward and backward in negotiating a jump. Shorter stirrup-leathers than this are useless, besides impairing the symmetry and ease of the rider. The best form for legs in cross-country riding is with the foot turned neither in nor out more than is perfectly natural, and the leg from the instep to the knee perpendicular to the ground. With the stirrup-leather of proper length, the hollow of the legs between knee and calf will then fit the horse's body at the fullest part. This position gives the rider's body the greatest amount of sitting surface, erect and well back on the saddle, which for hunting should be longer in the seat than for ordinary riding. (See illustration, page 92.) 


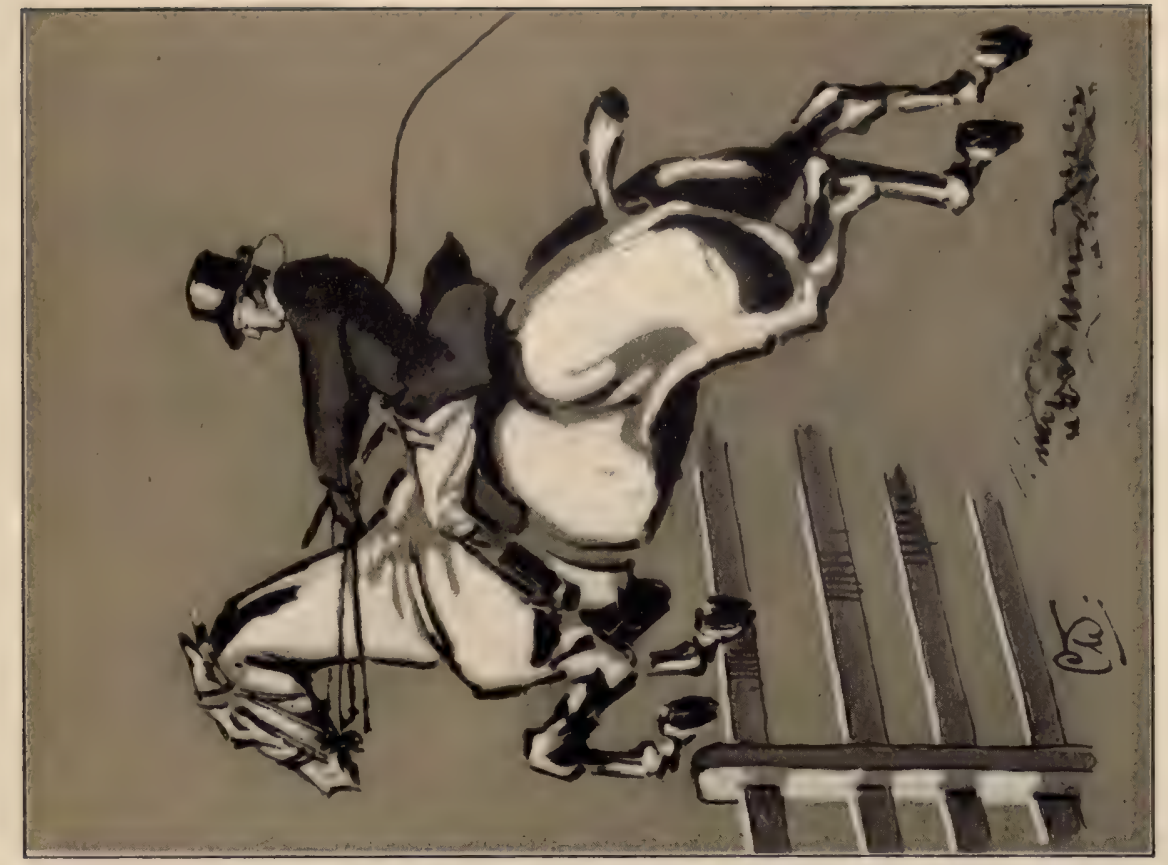

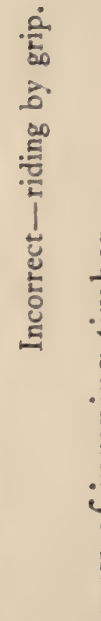
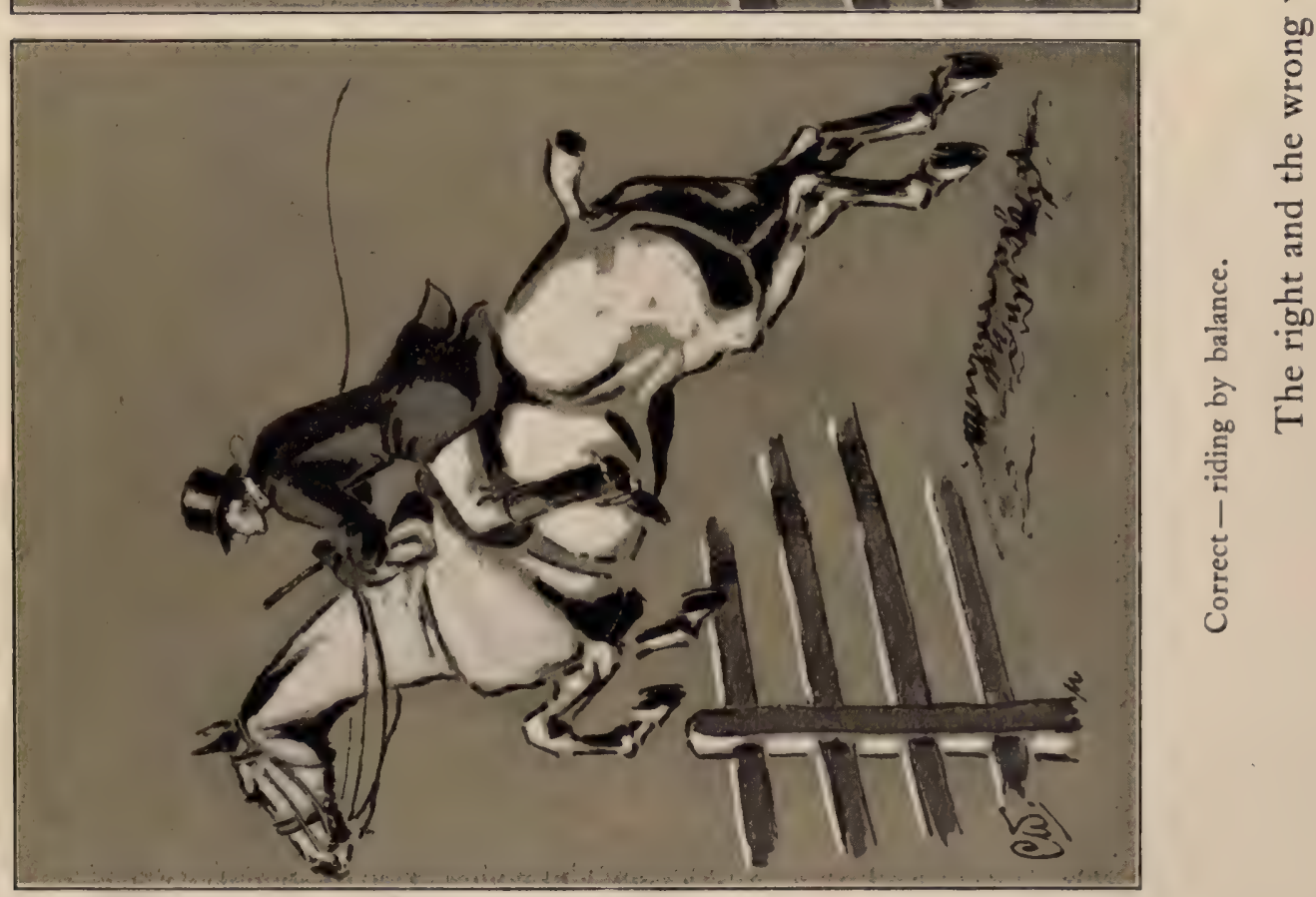
I am persuaded that such a position, such form for arms, legs, and seat, together with entire dependence on balance, constitutes a way of riding at once the most natural and graceful and the most secure. I never yet have seen the man who, riding at all by grip, could sit down well into his saddle when his horse was at a canter. In this respect English riders are something shocking. At every stride of the horse they go clear of their saddles with from one to four inches of daylight between their saddles and themselves. Except when a horse makes some extraordinary movement, a man who rides by balance never shows the least bit of daylight between himself and the leather. The grip man depends so much upon the pressure of his legs and puts so much of his weight upon his stirrups that the least jar elevates him - bump, burnp, bump.

There are doubtless many riders in England, many riding-school-taught riders in America and military-taught hunting men in other places, who are half or more than half converted to the idea of riding by balance, who often find themselves riding in this way despite all discipline to the contrary. As to sitting a horse by balance when jumping a fence, however, they shy at this or refuse to try it altogether.

In the chapter on the conformation of the hunter, on the subject of shoulders, we had our say about centres of gravity and the necessity that the horse should be so built that in taking a fence the rider's centre of gravity should come as nearly as possible over that of the horse. With a horse so built and a rider so placed, riding by balance over a jump is not only a possible but, in my opinion, the only 


\section{Cross Country with Horse and Hound}

proper way to ride. It is the only natural way for both horse and rider. For the horse, the difference in taking over a fence a rider who keeps his equilibrium by balance and one who holds on by grip is so much in favour of balance that the grip theory is completely demolished.

At page 96 we have an illustration of a rider who, riding by balance, is leaning well forward while his mount makes the ascent. A line drawn from the top of the rider's head to his horse's heels as they leave the ground follows the centre of gravity; the equilibrium of the rider is maintained with ease; also the weight on the horse's back is in a position to be lifted with the least possible expenditure of strength.

At the same page is shown a rider taking a fence with his body held in position by a grip of the legs. With him the centre of gravity is far back of that of the horse; and whereas the balance rider is lifted with the least possible exertion, the grip rider is, so to speak, elevated at arm'slength. In the one case the rider, sitting by balance and entirely independent of the reins, is in the only position where he can give to his mount the freedom of head which is absolutely essential to perfect performance. In the other case the rider, sitting by grip and, thanks to his rigid position, thrown forcibly backward as the horse springs, must depend on the reins for his support.

Can any one imagine a more nearly perfect form, theoretically and practically, for man and beast, than the balanced seat over a jump, or one more uncomfortable for the man or more difficult for the horse under his rider's weight than the rigid seat? To those who think riding by balance 
well enough on the level but impracticable for fencing, let me say it is more essential at this point than anywhere else.

Let us hurry our two riders on over a fence and see them safely landed on the other side. Directly over the fence both riders assume, for an instant, the same position. This instant is the only one, however, between leaving the ground and landing again, where the rider by grip is riding his horse. Before that and after that, as we shall presently show, he is not riding but hanging on. As they begin the decline the man riding by balance gradually leans back until his centre of gravity pulls downward in a line drawn from his head through his body and the horse's fore legs. Can a better position be imagined for the comfort of the rider or for his safety? Can any one place the weight of the rider in a position to be lowered to the ground with less exertion to the horse? What of our grip rider, whose body still remains in the same rigid, unyielding position? Can any one suggest anything he could do to make his position more uncomfortable for himself or his mount? Look at page 98 and see our grip rider descending with his horse's head still in a vice. Could he place himself with hands and seat in better form to make his horse turn a somersault on landing?

In the former case the horse alights and goes forward in the same smooth stride that he had on the level. In the latter, being thrown out of balance by the rider sitting out of balance, he has to put forth as much muscular exertion to land his rider as he had to lift him. It is not too much to estimate that the one horse can take a hundred and seventy-five pounds over a four-foot-six fence with less 


\section{Cross Country with Horse and Hound}

exertion than the other would need to carry over a hundred and twenty-five pounds.

And whatever the difference may be in theory, it is even greater in practice. When we consider that by balance the horse himself must negotiate a fence, and how little a thing upsets even a man on his feet, the trial it must be to a horse to jump with a weight on his back all out of balance from start to finish is apparent. The wonder is that one does not see half a dozen falls in the hunting-field where there is but one. Drag huntsmen will hardly appreciate this discourse on jumping, for they take their fences as they take their ditches, flying. But to men in timber countries it must be apparent, we repeat, that the only one way to ride a horse and do it properly is by balance.

The crying need in riding-schools is some teaching of sitting a horse naturally. "Buffalo Bill's" exhibition in England was a revelation as far as seat was concerned. There is no country in the world where they do so much horseback riding as in England, but nowhere can you find such bad seats. If you wish to see how not to ride, and a fine example of grip riding, pay a visit to Hyde Park. It is bump and co-chunk, with from four to six inches of daylight between their saddles and nineteen riders out of twenty, the horses cantering at that. Grip does it. 


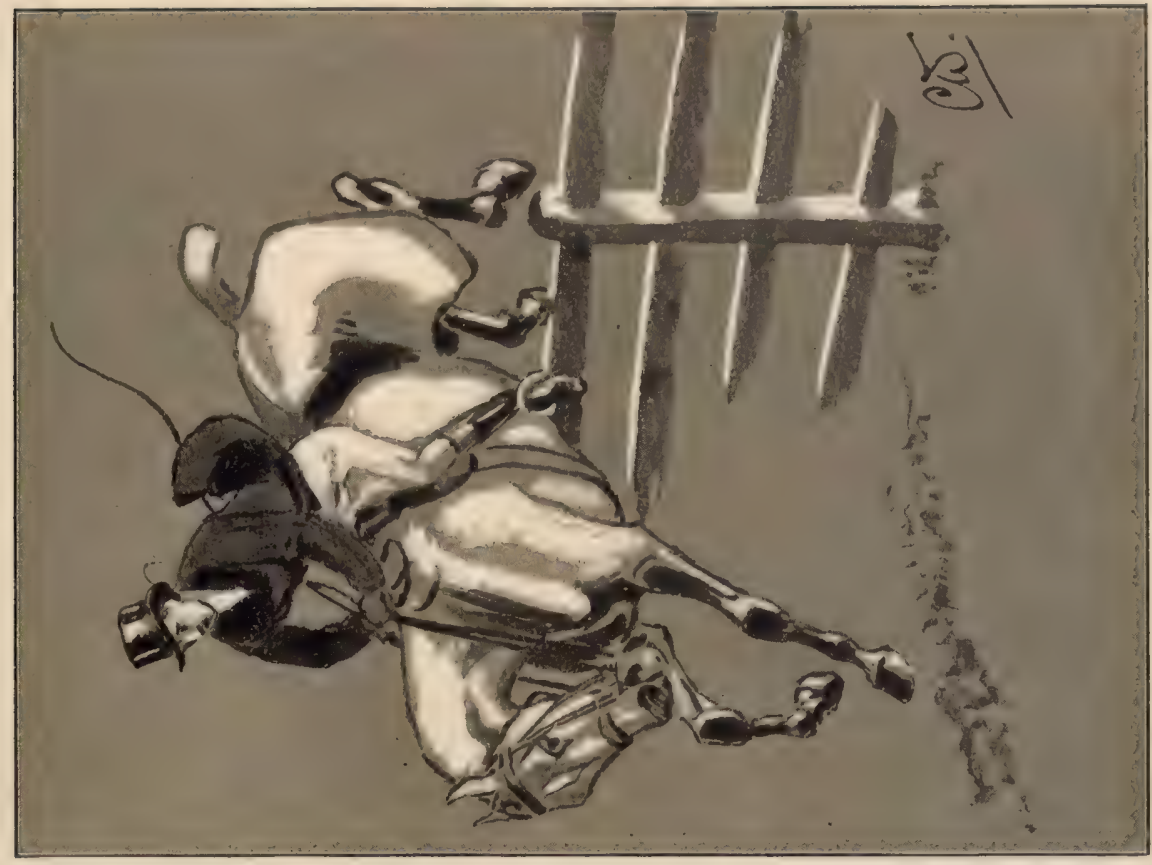

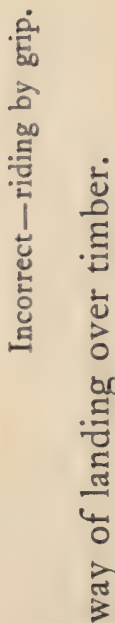

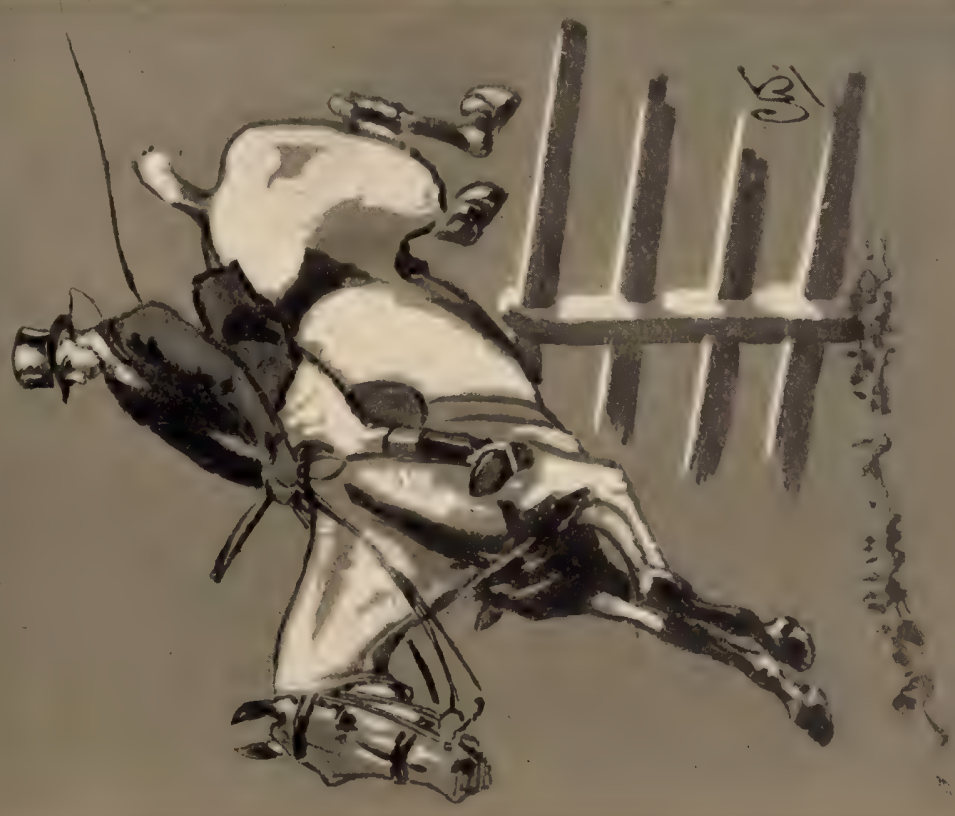

范 

VIII

\section{HANDS}


"Who tugged at his horse and held on to his head With hands like a vice as if loaded with lead. I saw at one glance that he was not the kind To blend with the horse both in body and mind." POEMS IN PINK 


\section{VIII}

\section{HANDS}

PULLERS: HOW THEY ARE MADE - PROPER POSITION OF HANDS HOW TO HOLD THE REINS - HANDS WHEN JUMPING

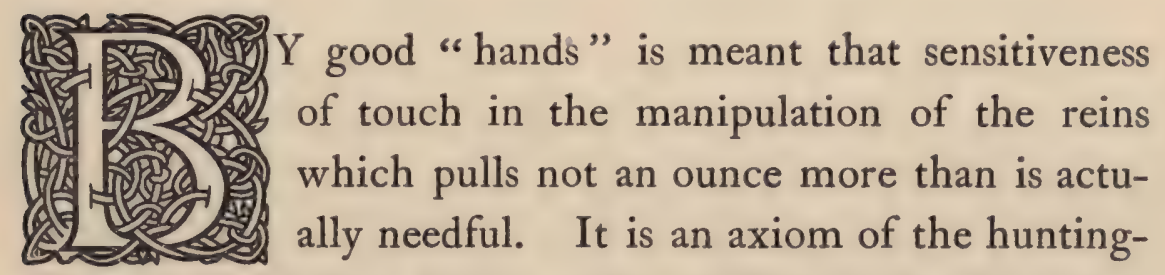
field that "Pulling hands make pulling horses," or "A dull hand makes a dull mouth."

"I never pull at my horse's mouth," says a friend of mine, "but all my horses are pullers. I don't understand it."

The trouble with my friend is that he is dull of touch. When he shakes hands with you he nearly crushes your bones, yet he is entirely unconscious of doing so. I have often remonstrated with him, but, I fear, to no purpose. Ladies shun him rather than endure the ordeal of a grip of his unfeeling paw.

Touch is a question as much for horsemen as for pianists, and almost as difficult to attain in perfection by one as by the other. In horsemanship we can learn from the lady rider a most valuable lesson. Her 


\section{I02 Cross Country with Horse and Hound}

hand is acknowledged everywhere among hunting men as being lighter and more sensitive of touch than a man's. Sensitiveness of touch is a gift, yet probably can be cultivated and improved to some extent. More profit is to be derived from giving our attention to the causes - bad hands and pulling horses, which invariably "hunt in couples" to which its lack is due.

The most fruitful source of bad hands is an incorrect position in holding the reins. It is a point susceptible of the greatest improvement. The proper position of the arms and hands is illustrated at page 92 ; the wrong way at page 104. In the right way notice that the arm from the shoulder to the elbow is perpendicular, the forearm at right angles to the upper, and that the hands are well in the lap of the rider, so that there is no weight whatever on the reins. The wrist is pliable to every step or stride of the mount. The correct position has been attained. A glance at page 1 04, which illustrates the wrong way of holding the reins, will show that with the elbows forward and the forearm in line with the reins or parallel to the direction in which the horse is moving, the weight of the hands and arms rests against the horse's mouth. This weight, moreover, is increased in proportion as the elbow is held forward of the perpendicular. In holding the reins with the arms extended, one causes all the give and take of the reins to come from the shoulder. The whole arm instead of the wrist must be moved, or, as is usually the case, remain rigid. This position of the hands is a constant dead weight against the horse's mouth. The rider is entirely unconscious of pulling the horse's mouth. He is not pull- 
ing in the sense that he is making a distinct muscular effort to do so. But he invariably acquires the habit, when reaching his hands well forward, of resting the weight of his hands and arms on the horse's mouth. This irritates the horse, who either refuses to go up to his bit or begins to pull. A horse pulls, as does the rider, from one of two causes: either because his mouth has been so deadened or calloused as to be no longer sensitive, or because he is being pulled. The former comes from improper bitting and breaking; the latter from the fact that beyond a certain pressure the harder he pulls the less pain he feels, the circulation being cut off and the nerves deadened. Thus it comes about that pulling hands make pulling horses.

This question of hands is much better understood in England than in America. The English are as superior to the Americans in hands as the Americans are superior to the English in seat. In England you will everywhere see good hands - farm-lads, butchers' boys, cabmen. Good hands in England are the rule, while with us they are quite the exception. The great majority of horses in America have had their mouths injured or spoiled altogether by heavy, unyielding hands.

The American and the English styles of holding the reins are illustrated at page I 04. The American style is the result of copying the jockeys in driving trotting horses, a style of hands which may be well enough for track work but is manifestly wrong for ordinary riding or driving. The same sort of thing is noticeable in American harnesses. Trotting horsemen use an overdraw-check in order to extend their horses' noses, for the purpose of giv- 


\section{Cross Country with Horse and Hound}

ing them the greatest freedom in breathing by making a straighter air-passage from the nostrils to the lungs. This style of harness may enable a horse to do a mile in several seconds less time than he could accomplish it in if the harness had an ordinary bearing-rein, or even no check at all, and, so far as speed is concerned, the overdraw has its legitimate use. It has, however, like the jockey's style of holding the reins, become almost universal. You can hardly find in a harness-shop in America a breast-collar harness that has not the overdraw-check on the bridle. It is seen everywhere, among farmers and among liverymen, and from it Americans have copied a style of holding the reins that results in the worst possible position of the hands for ordinary riding and driving; and the very best that could be adopted for making pullers. There is no room for doubt in the matter - the one great drawback to American horsemanship is bad hands; the nation is in this respect just about as bad as it could be made : yet it is the one thing needed to make Americans the most finished riders in the world.

And good as the English riders and drivers are in hands, the Irish horsemen take the prize from them. The Irish are simply perfection. They ride with a light Pelham bit, which is simply a curb-bit without a snaffle. It is a very severe bit, but with their masterly hands they leave it severely alone. By this same token I should think it an excellent thing for any one who wished to cultivate good hands to practise riding with curb-lines. The consciousness of the bit's being so severe would make one very careful how he took hold of it. A bit like this in a tender mouth 


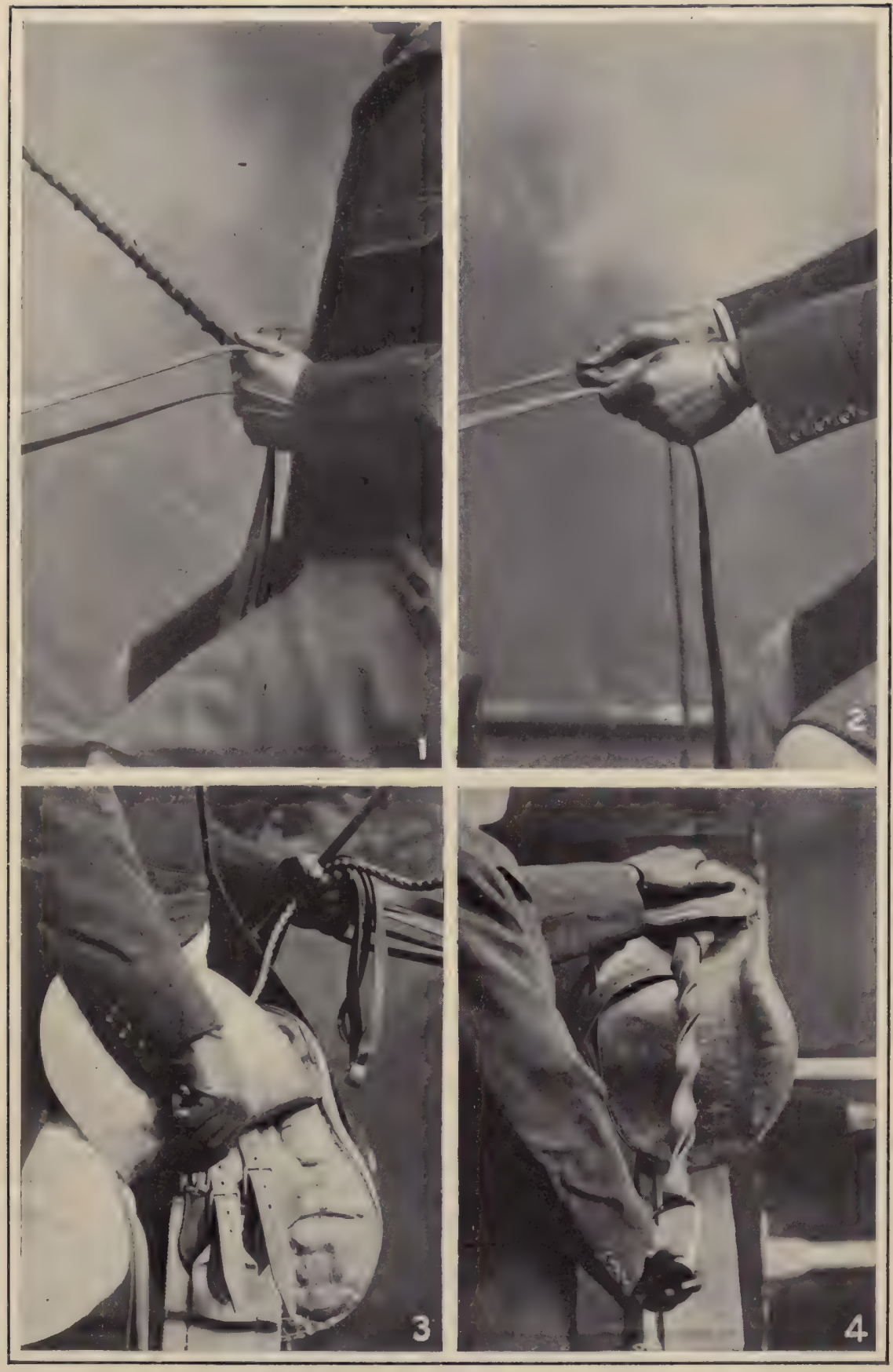

1. Hands in driving, correct.

z. Incorrect.

3. Shortening girths while mounted.

4. Twisting stirrup-leathers. 

would soon teach a man to let it alone. But of course, before he should attempt it, his seat should be so perfect as to be independent of the reins for support under all circumstances. "Handle your reins," says one authority, "as if they were silk threads and liable to break." This is good advice, but it cannot very well be put into practice unless the hands are in their proper position, as illustrated at page II 4 , and if the seat is not perfect. If one wishes to demonstrate how much of a dead weight there is against a horse's mouth when the rider's elbows are extended and the forearm is straight, let him attach a weight to a pair of reins and take hold of them with hands extended, American style; let him keep adding to the weight until the weight of his hands and arms is balanced, then take the reins in his one hand as illustrated by the English style, and note the difference.

It is very discouraging sometimes to undertake to make over a puller. When you begin to think you are making progress, something upsets your work and he gives you another day of it in spite of all that you can do. From a rusher over his fences and a puller between them, good Lord deliver us! Such a horse not only tires his rider but exhausts himself to no purpose. We have shown in the chapter on horsemanship how essential it is to be on good terms with one's horse, but no one can possibly accomplish this when there is a fight going on all the time between himself and his mount.

A horse pulls from two causes - dulness of feeling, or to ease pain. In the first case the chances of recovery are generally hopeless. When, however, the pulling begins 


\section{Cross Country with Horse and Hound}

after you have been riding a way and increases as you go on, you may know it is to relieve pain, and by that same sign that the fault is with yourself. In the first case there is little you can do except to drop the bit well down in a new place and make the best you can of the situation. In the latter case, as the fault is principally with your riding, it is simply a question of cultivating your hands. If it is a congenital want of sensitiveness of touch, I do not know of any help. If it comes, as it usually does, from a faulty position of the hands, the remedy is with yourself.

The habit of pulling, in a great many cases, comes from a bad or improper seat when negotiating a jump. I have already called attention to this point in the chapter on "Seat." The reason a horse gets to pulling, or rushing his fences,- except in cases of funk on the part of horse or rider, - is that when a man sits rigid and is obliged to catch at the bridle-reins for support he punishes the horse's mouth so severely that the moment his feet touch the ground, away he rushes as if he had had as severe a jab with the spurs as he actually has had in the mouth. When a horse has been ridden over a few fences in this style, he associates that awful jab in the mouth with the act of jumping. He knows as he approaches a fence that there will be a pull at his head enough to extract a tooth, and he naturally rushes to get over the agony as quickly as possible or refuses the jump altogether. Nor is this all. When he gets within eight or ten strides of his fence he goes at it with two or three times the amount of force required to clear the obstacle, all of which is only so much more energy consumed to no purpose. So matters go on 


\section{Hands}

from bad to worse until the horse becomes a confirmed puller.

I repeat, if you cannot sit a horse over timber without catching hold of his mouth to support your body, you can assure yourself that you are not qualified to ride a good horse across country to hounds, and that the fault is with your seat more than with your hands. I may be pardoned for repeating again that the most important of all things in cross-country riding is to give your horse perfect freedom and liberty of his head when negotiating a fence, especially timber. If you have so ridden him as in no way to hamper his movements, except so far as your weight is concerned, and he makes a mistake, it is not your fault. And do not deceive yourself: a horse knows enough to place the blame where it belongs. Mr. best English authorities, says that nine falls out of ten in the hunting-field are the fault of the rider, and I think he is not far astray in his reckoning. A friend of mine tells me: "You might say, what would be perfectly true, that nine men out of ten would fall off if deprived of their reins."

It is said of the great Atherton Smith that when he came to a very bad jump, rather than have any question of whose fault it was, his or his horse's, if they went to grass, he would throw the reins down on the horse's neck and say: "Now, then, look out for yourself!" That is the principle on which one should strive to make every jump.

I confess it is much easier to tell how all these things ought to be done than it is to do them. Perfect form in all respects in riding to hounds is rarely seen in one man, 


\section{Io8 Cross Country with Horse and Hound}

and I am conscious of not being an exception to the rule. One thing, however, is certain : if we know how it ought to be done, we can forever keep trying, for one never is too old to learn.

I fancy some of my readers by this time are asking if I mean to say that a horse ridden with hands in the proper position will never pull. He may, of course; but you at least know that so far as in you lies it is not your fault. He may pull for ambition's sake, or desire to go through timber faster than is safe, or faster over soft ground than you, husbanding his staying powers, care to have him. Perhaps he is inclined to be a little hot at his fences because he is more than half a funker. Then take him by the head as sharply as may be necessary, but the instant he answers your pull, let up. Never keep a dead pull against a horse's mouth. It is better to shift the bit from side to side. If you keep on pulling long enough you will deaden sensation and develope a real, not a temporary, puller. After all, how is a horse to associate slackening his pace with the slackening of your pull if you pull all the time? No horse is made a puller by being taken up short the instant he begins to take liberties. The steady dead pull on the flat, the jab in his mouth at his jump, are what do the mischief.

I cannot agree with the notion prevalent among hunting men that hands are a gift, which, if a person is not born with it, he can never attain, however hard he may try. I grant this if it is a mere question of sensitiveness of touch, but not if it comes, as I believe it generally does come, from a faulty position of the hands. In contending this 
point I may be pardoned for again making a personal allusion.

When I began riding to hounds, with no qualifications whatever except seat,- - which I had acquired riding farmhorses, colts, and an Indian pony bareback when I was quite young,- I soon discovered that every horse I rode to hounds took to pulling. I was indebted to Mr. Thomas Hitchcock, Jr., for my first lesson in holding the reins, which, needless to say, had been — in the beginning — after the usual American style. This was the sportsmanlike way in which he went about it. Instead of taking me to account personally, he read a lecture to one of his grooms one day in my presence on the shocking bad hands he had - which were, as a matter of fact, an exact reproduction of my own style of holding the reins. Mr. Hitchcock next showed him how to hold them properly, and gave the reasons. It was a lecture from the shoulder, and I remember feeling rather sorry for the groom, until I remarked that he was taking it all in with something of a knowing smile on his face. That Mr. Hitchcock was never heard to correct a man in the presence of other people, and that the groom in question had been with him several years, came to my knowledge later; but the lesson had the desired effect. It was my first lesson, and, as I look back upon it, I think the most important lesson I have ever had. I mention it to show that I have reason to know whereof I speak in comparing English and American styles of holding the reins.

A year or so later a very practical demonstration of hands was given to me when I learned to drive four and tandem. 


\section{I Cross Country with Horse and Hound}

I had hastily bought a very wonderful "goer," which was driven to a railway-station for my inspection while the train stopped. Upon the completion of the purchase I sent my man for him, and he came into my yard, after his drive of fourteen miles, with the lines wound about his hands, and declaring he had pulled himself and the wagon every step of the way from Pearl Creek, that the traces had not been taut once, and that the "britchen" was tight nearly all the way. I had bought the horse for a tandem leader, but he was, as the groom said, an awful puller. Now it so happened that the order to the stables had been confused and the puller put in the lead. We started. Imagine our surprise when, instead of developing his usual pulling qualities as the distance increased, our puller-leader quit them altogether, and that before the end of the first drive. We kept him at it for a few weeks, and he never pulled after that in any harness. He proved to be the most perfect horse in the lead I ever drove. Since this episode the first thing I do with pullers or heavy-mouthed horses is to put them through this tandem school, and it has never failed to benefit them greatly and in most cases to produce a virtual cure. Many a horse that pulls when at the wheel will go beautifully in the lead. I do not hesitate to say there is nothing better for a heavy-mouthed horse than to be put in the lead tandem, and nothing better for a man with heavy hands than to practise tandemdriving.

There is, further, in all this an important lesson; namely, that in breaking colts to drive we should use long reins. Length of rein in riding certainly adds materially to the 
ease of handling the bit, though I should not go so far as to say, as many do, that ladies, by merely sitting farther back on their horses, and having correspondingly longer reins than men, owe to this alone the wonderful superiority of their hands over men's. We may discuss this point further under the chapter devoted to "The Lady Rider."

In general, riding with loose or slack reins is not only bad form but is bad in theory and in practice. The reins should be so held as always to maintain a slight touch of the bit-no more if you can help it, and never any less. If a person is sensitive enough of touch and will allow his wrists to give and take to the oscillation of the horse's head motion, he will be able to keep on the bit that most desirable, even, steady pressure that best suits a horse and gives to the rider the invaluable distinction of possessing good hands. An excuse may be granted for riding a hardmouthed horse with tight reins, but there is no excuse whatever for riding any horse with a slack rein. Slackrein riding gets a horse into slovenly ways of going. By a continual touch upon the bit, however, a horse may be guided to the right or left by an almost imperceptible touch of the reins.

Hands are never a less important point than they are in jumping. Turn a horse loose in a runway and observe how he handles his head in taking a jump. First he slackens his pace for the last stride or two, as do deer and cattle and dogs before they spring. Then he throws his head up instinctively with the lifting of his fore legs, higher than it is naturally carried, and after the obstacle is cleared, or while he is clearing it, brings his head down again and then 


\section{2 Cross Country with Horse and Hound}

up as his fore feet land. These motions of the head and neck must assist wonderfully in making the jumps, for they show, for one thing, that the horse uses this throw of the head and neck to assist him in preserving his balance. The necessity of giving a horse his head when he is jumping is obvious, and to be able to do this requires two things: first, a perfect seat, and second, a rider that sits his horse by balance. If the rider cannot take a fence with his horse without steadying the weight of his body against the horse's mouth, he may know by this sign that he comes short of the requirements.

As a horse, when brought to his jump in a deliberate way, begins to lift his fore legs from the ground, all the rider has to do is to lean well forward and drop his hands until the reins are slack, * then lean back on the decline of the jump and take his horse well in hand as he strides away on the level. The great trouble with many of us is that we cannot let the reins alone, having the absurd idea that in some way we must assist our mount to rise or to land. The practice of catching hold of a horse's head by a pull on the reins as he begins to rise at a jump, with the idea of lifting him, is one of the most absurd notions that ever entered the mind of a cross-country rider. It is a practice that is altogether too common. Whyte-Melville, to quote again his valuable work "Riding Recollections," tells of a celebrated Yorkshireman who used to say: "Every horse is a hunter if you don't throw him down [at his jumps] with the bridle."

I do not mean to say that every one who rides by balance can ride a horse through a stiff run in a rough timber 


\section{Hands}

country and never need the friendly aid of a pull on the reins or a grip with the legs to assist him in keeping his - balance. He will need them, certainly, but only as the law of self-preservation directs. There are a great many ifs in the way of attaining perfection in cross-country riding, because the requirements of horse and rider are so various. Perfection is rarely found in either man or beast. We find horses that will stop if you slacken the reins as they are about to spring: they have so long been ridden over fences with the rider's weight on their mouths that when they are given their heads they think something has happened. Long custom has taught them to expect it, and if it does not come it is as likely as not to throw them out of gear, and the rider out of the saddle at the same time. What then? Why, ride the horse as he wants to be ridden. That is horsemanship.

The standard of excellence for horse and rider is so high, and, as I say, the requirements are so numerous, that no matter how great our experience has been, there will always be something to strive for, something to learn. This is the great charm of hunting; it is a science within a science. If it were to be mastered quickly or easily the zest for it would not have persisted all these years. It is like billiards, or fencing: you never do so well at either but that you know you might have done better.

Let not the novice be discouraged, however; the best that the best can do is to set before himself a standard of perfection, and work and delve and strive to attain it. The game is pursued with increasing interest only by the men who strive in this persistent way to master it. 
I 4 Cross Country with Horse and Hound

As to holding the reins in the hand or hands, there are numerous ways. Two of these ways, at least, are good, and both have strong advocates. The proper way of holding single and double reins is shown on the facing page. The way to carry the crop, and the way of changing reins from two hands to one are also shown. In handling the four reins in one hand the curb-reins are in the middle, the off or right-hand rein under the forefinger, the nigh or left-hand rein under the little finger. They are thus easily sorted, shortened, or lengthened. 


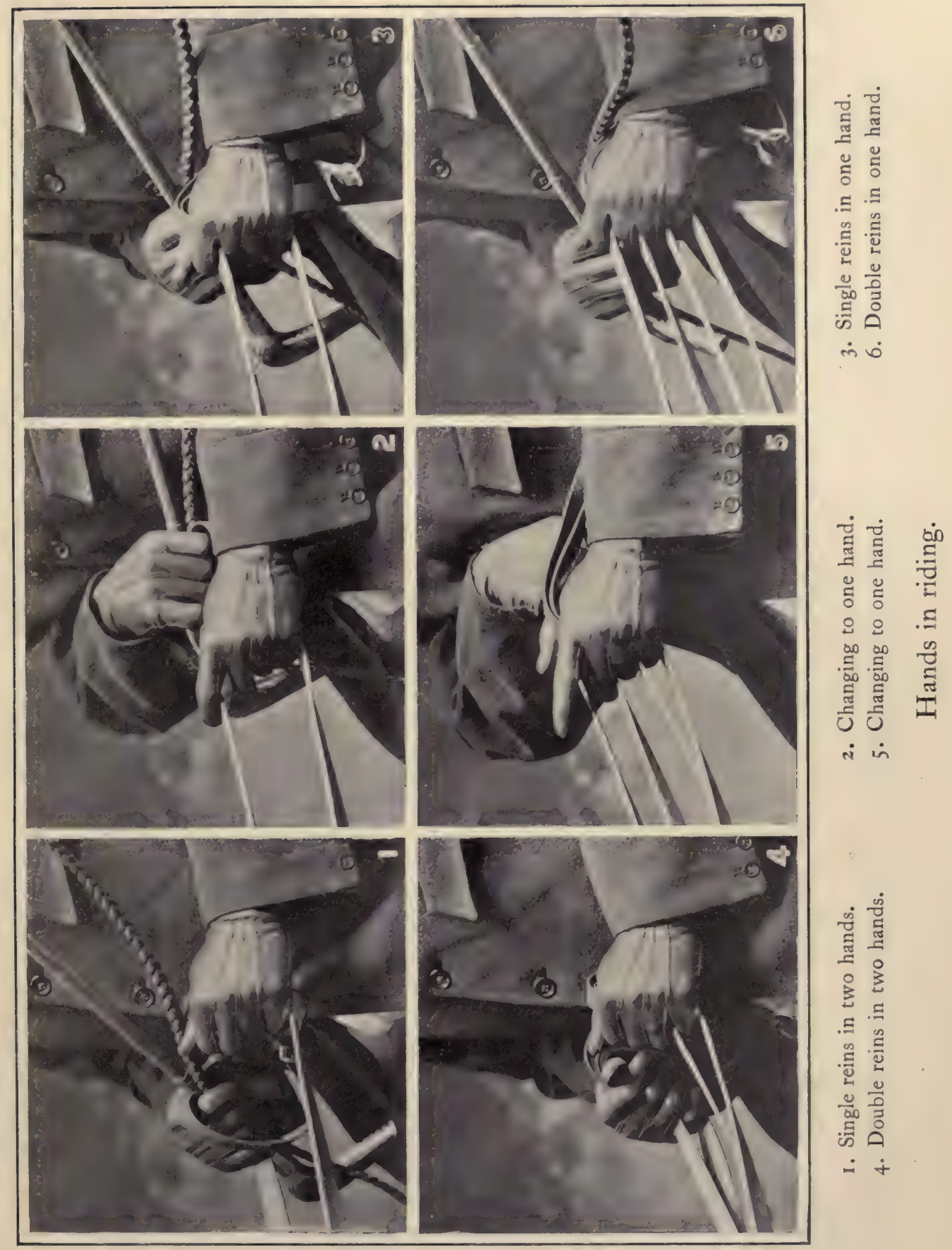



IX

JUMPING FENCES, DITCHES, AND WATER 
" But where was the gemman in pink

Who swore at his tail we should look?

Not in the next parish, I think,

For he never got over the brook."

HUNTING SONG 


\section{IX}

\section{JUMPING FENCES, DITCHES, AND WATER}

THE RIDER - HIS MANAGEMENT OF HIS HORSE - SPEED AT

TIMBER AND WATER

E have taken note of the schooling of the
horse in going over fences; we must now he can help his mount.

To begin with, a horse should be brought to his fences well in hand, with hocks well under him; for nothing is more certain than that the shorter the horse's stride when nearing the fence, the more power he can make use of in the spring. It is self-evident that if your horse is going at a fence full speed in an extended gallop, he will not have his hind legs under him long enough to use the contract force of his muscles to their greatest advantage ; his momentum will be too great. (See page I I 8.)

"Fast at water, slow at timber," is the rule; but I believe more horses go into than over water by too much speed. Besides, a horse at full stride will only occasionally reach the take-off bank just at the right spot. My experience is that the injunction to be fast at water needs 


\section{8 Cross Country with Horse and Hound}

qualifying. That more impetus is required to make a broad than a high jump, it is reasonable to suppose; but a too long or a too fast start is as apt to defeat one's ends as going too slow is. If a horse has speed and impetus enough to carry him over say twenty feet of water, as no doubt he has when racing at it full speed, the trouble may be, nevertheless, that although he has only to lift his feet and let the momentum do the rest, he feels that his muscular force has been spent in running. He has not enough left, or cannot collect what he has forcibly enough, and so refuses or drops aimlessly into the middle of the stream. If, on the contrary, he had but taken a shorter stride, he might have cleared it. Any one who has practised broad jumping will know exactly what I mean by this particular difficulty. There is such a thing as going back too far and coming at the water too fast when one could have done quite as well perhaps from a standstill. There must always be a reserve force in your horse for the spring. When a horse is brought up to within three or four strides of the obstacle, well in hand, he can better judge his distance, whether over a fence or across a bit of water.

There is also at least one exception to the rule that one should go slow at timber; when, namely, there is a ditch on the opposite side.

In "Forty-five Years of Sport" James Henry Corballis says: "A horse can jump bigger and better when ridden at a moderate pace. I have trained many of my horses," he continues, "to jump so big from a stand that they couid accomplish fences which were impossible to fly; and in a close, cramped country such training is most invaluable. 


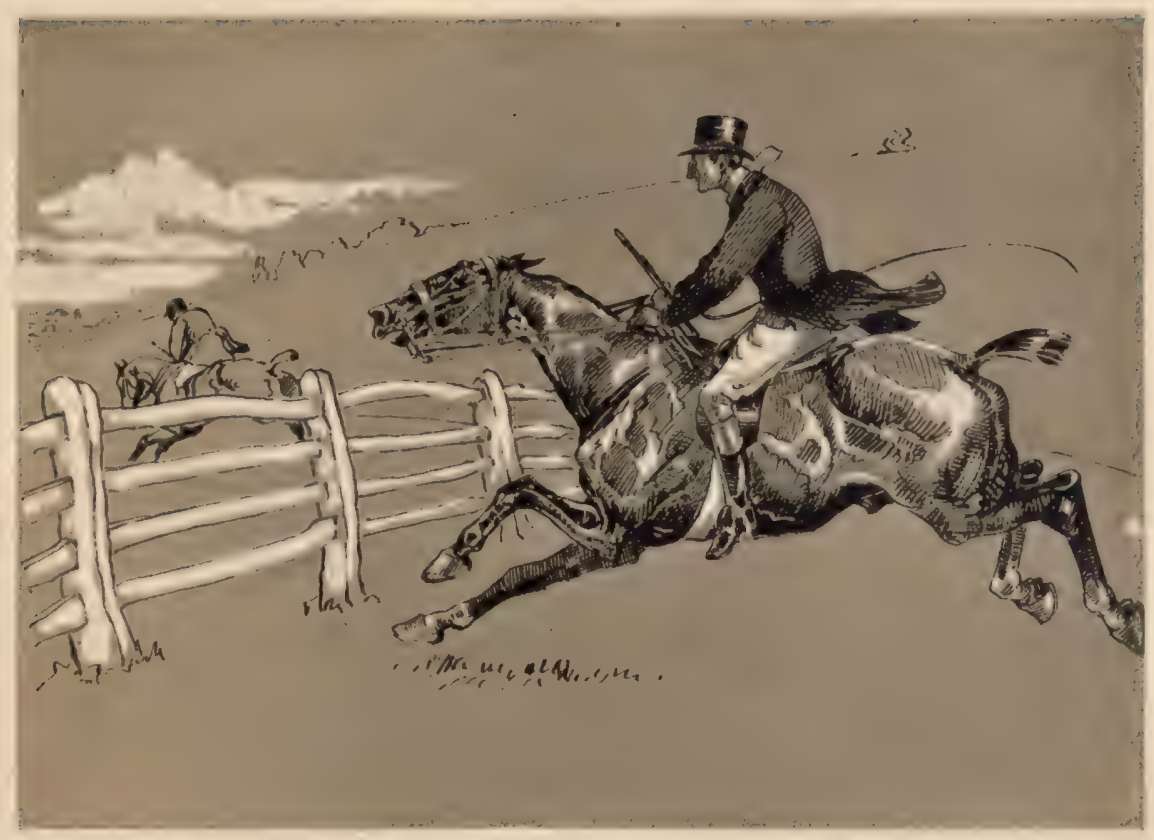

Fast at timber, too extended.

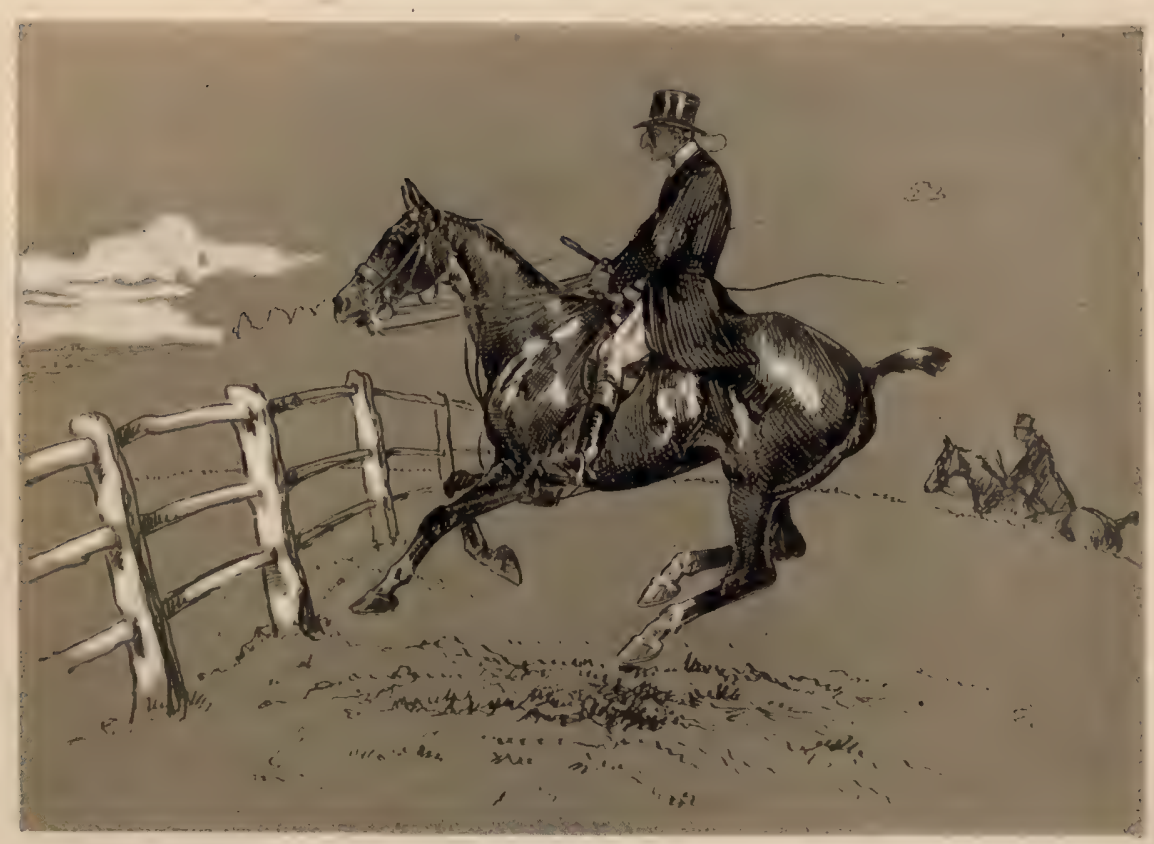

Slow at timber, hocks well under. 



\section{Jumping Fences, Ditches, and Water I 9}

The late Mr. Leonard Morrogh, a well-known Master of the 'Ward,' trained most of his horses to jump the most ugly and impossible-looking fences from a stand, and thus even at the end of a long run his horses were, comparatively speaking, fresh. I took a hint from Mr. Morrogh's system, and in like manner trained my own horses, and produced many a slow-jumping 'wonder,' and in consequence saw the end of many a twenty-five-mile run."

Nearly any horse, if he is given time to collect himself and is not distracted by whip and spur, will, if properly trained, know how best to take off and land safely. It is astonishing how easily a horse will negotiate a most difficult jump if there is nothing to interfere with the free use of his legs, head, or neck, and if the weight on his back is properly adjusted.

It is equally surprising what a little thing upsets him when he is deprived of any part of this freedom. If you doubt this, try a few jumps yourself naturally, and then unnaturally hampered in some way. You will find that the least deviation from the natural way is a very great handicap to your making either a high or a broad jump successfully. 

X

SPURS 
"One spur in the head is worth a dozen in the heel."

" Pompous encumbrance! A magnificence Useless, vexatious!'”

SOMERVILLE 


\title{
$\mathrm{X}$
}

SPURS

THEIR USE AND ABUSE - RELICS OF BARBARISM

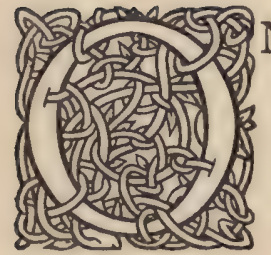

NE spur in the head of either rider or mount is worth a dozen in the heels when chasing the fox. I confess I have a decided prejudice against the use of spurs, except as an ornament to a well-fitting boot. They have, I believe, done ten times as much harm as good. They are used a hundred times uselessly to once of real necessity.

As a matter of fact it will be readily understood to follow from the system of training and schooling herein advised that the spur is a useless instrument. My idea, as I explained in the chapter on Schooling Hunters, is that nothing whatever should be done to flurry, distract, or annoy a horse in the act of jumping, much less to injure him, because he thus associates injury or annoyance with his jumps, and dreads them or refuses altogether. The more you spur or whip, the more you will have to. The principle is wrong and thoroughly inconsistent with the proper education of a hunter. The spur or the whip is a stimulant, and, like liquor, the more it is indulged in, the more the need of it is felt. A horse can be driven through a run




\section{24 Cross Country with Horse and Hound}

and made to jump with wicked rowels piercing his flanks, there is no doubt; but this is not horsemanship: it is torture. We should abhor the thought of thumb-screws or the lash to force a man to any dreaded task, but we do not hesitate, some of us, to rowel the sides of a horse until he is in a state bordering on frenzy. He jumps as a man would jump from a third-storey window with a fire behind him. Do we never stop to think of the state of mind a horse must be in who fears to jump a fence and hesitates until the terror of punishment overbalances even the dread he feels for the jump? That his fear - in your mind - is groundless does not lessen the terror in his own mind. Spurring or whipping would not lessen a child's fear of "the dark." Confidence learned by degrees, however, may. What horses need, too, is confidence, not spurs. What we need ourselves is confidence in ourselves, not stimulants. Confidence of horse and rider in themselves and in each other - anything you can do to promote this will make both parties to the partnership more proficient in cross-country work. Anything you do to your horse, and anything your horse does to you, whatever it may be, in whatever form it may be done, that tends to destroy this confidence, that much is being done toward defeating the end in view. At the harrow or in harness you may use a horse for the sole end in view, as you would a machine; but hunting, as I have said, is a partnership affair. The more intimate the association between rider and horse, the better must be the results.

No one can estimate the difference between riding a horse to hounds whose heart is in the game and whose spur is therefore in his own head, and one who goes through the mo- 


\section{Spurs}

tions like a slave, and has to be rowelled over the fences and quilted between them. That some men regard their horses as nothing more than machines on which to "get there" is apparent to any casual observer. The abuse of the spur in the hunting-field has left a bloody trail over the otherwise clean record of many a sportsman. I believe that spurs are wholly unnecessary to a hunter if they are never used to begin with. You may get a horse over a jump with them, but the after-effects are as bad as spurring yourself on with whisky. It is the abuse of both that I am speaking of. The actual necessity occurs probably once in fifty times, but from this once riders get into the habit of using them indiscriminately. If a horse will not go through a run without this tormenter working in his flanks, one may know he is not a true sportsman or has not had proper schooling, and had better go back to the trainer or be sent to the harrow where he belongs.

"Shall I never wear spurs?" I am asked.

Yes, if you never use them.

"But shall I never have occasion to use them?"

I cannot prophesy for any one's future. I have ridden to hounds more or less for the past twenty years, and never used them since my first two or three seasons. A touch of the crop or cutting whip is quite enough.

Custom seems to have dulled our sensitiveness to the inhumanity of spurs. If we stop to think, how horrible it is to see a comrade thrown over his horse's head, leaving a trail of blood on his horse's neck from the saddle to his ears! Who has not turned aside rather than see the sharp rowels of a spur ploughing across the loins of a horse that has 


\section{26 Cross Country with Horse and Hound}

refused a fence? Who has not felt more sorry for the horse than for the rider when both have fallen? The side of the horse is marked with a great clot of blood. A hundred times the spur is used for the once that it ought to be. A hundred times it is used by accident or unintentionally for every occasion when it is necessary. How many times has one seen riders, in going through woods, stab their mounts in the side as their legs are bumped against trees or saplings, or again when they duck their heads to clear a limb! Is it any wonder that some horses hate hunting, and cringe and shiver when the groom hands them over to the tormenter?

Many of us fail to appreciate what a gulf separates the horse who hunts with an incentive in his own head from the one who is driven on by pricks and stings. They are as wide apart as love and hate. Let me admonish you, my novice reader, whatever you do, take your mount into the game on equal footing with yourself. You may not always think alike. You must expect to be annoyed, discomforted, and perplexed. But keep this in mind: you are the partner, with your greater degree of intelligence, from whom must be expected the greater degree of forbearance. Superior horsemanship, let me repeat, is distinguished from inferior horsemanship by ability to adapt one's self to the horse. It is only novices or the uncultivated in horsemanship who insist on making horses conform to their ways.

"What!" some one protests, "would you put yourself on a level with the brutes?"

Precisely. It is impossible for "the brute" to move to your exalted state of intelligence. Seek, therefore, to 


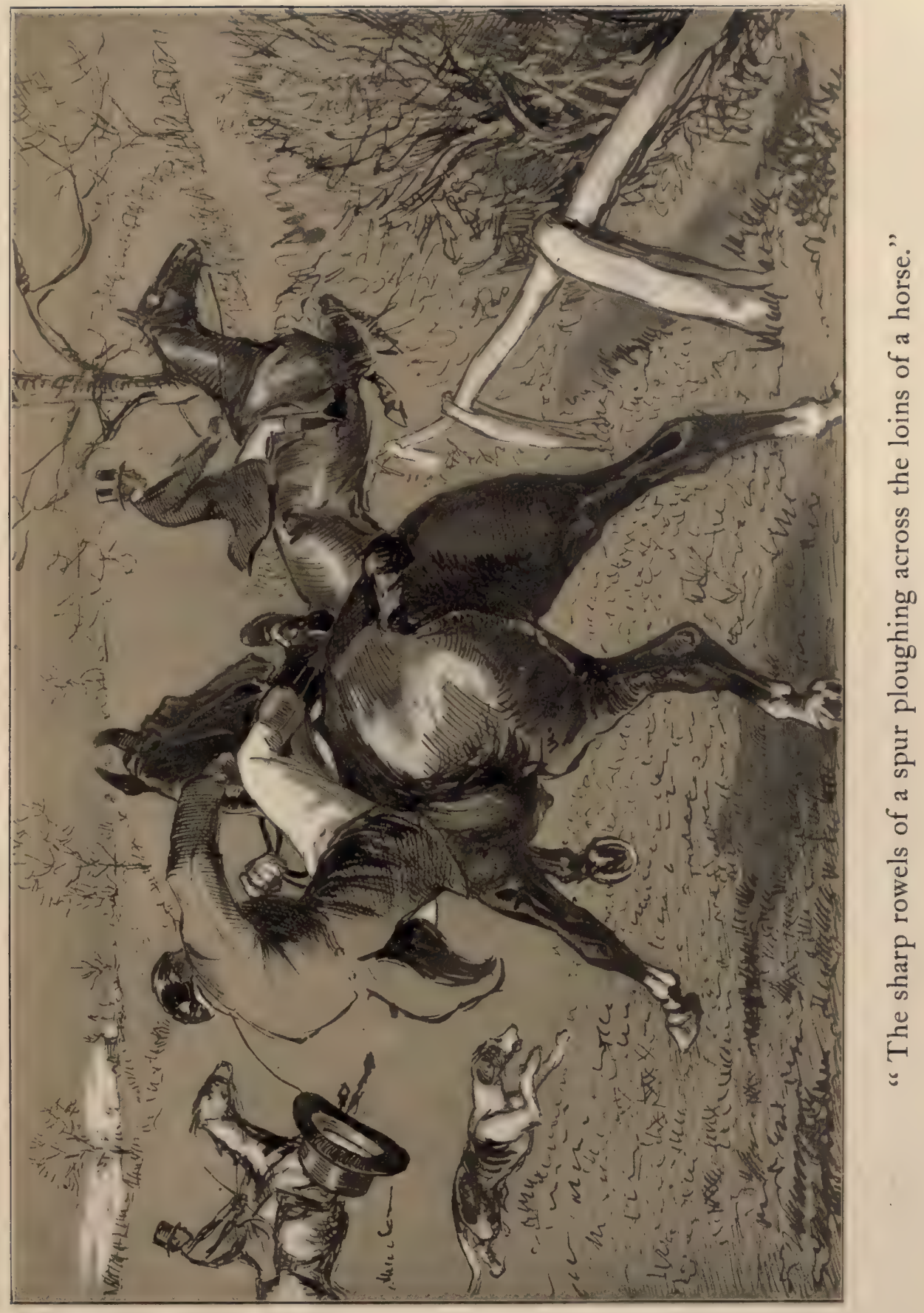



mould and fashion his actions to your way of thinking by association and by example.

A horse learns by absorption, by companionship, not by reason; and as his sense of intuition is many times keener than a man's, one will be surprised to notice how quick and clever he is at divining his rider's thoughts and wishes. The man's is the master mind, and if he is a genuine sportsman in all things he will in no way seek to take advantage of his less fortunate companion. A man is affected by the company he keeps. A horse is so affected, too, only a great deal more so, because intuition is the keenest of all his faculties.

Let your greater strength of mind direct his greater strength of body. Place yourself in the attitude toward him that will best enable his keener instinct to acquire confidence in you. Thus he will learn to lean on you, respect you, consult your wishes, have faith in all you say and do. This once accomplished, every day's sport together only cements that indescribable bond of friendship which is yours for the cultivation, and makes a day to hounds one of the most enjoyable things in life. This sympathetic bond of friendship is what makes English riders the keenest crosscountry men in the world, and it is itself easily explained by their natural love for animals. Without this companionship between rider and mount in England fox-hunting would never have come to be what it is; it is the very essence of the game.

The spur is a relic of barbarism. Here is an ancient prescription for its effective use from "Records of the Chase" by Cecil. It is given as a quotation from a very 


\section{28 Cross Country with Horse and Hound}

old work on hunting, "believed to have been written by a son of Edward III in the fourteenth century":

\section{FOR DEFY OF THE SPUR}

Take and shave him [the horse] the breadth of a saucer on both sides there as you will spur him; then take a lancet and make six issues through the skin the length of a wheat corn, and then take a haundelere and raise the skin from the flesh and then put in a quantity of burned salt, and this will make the sides to wrankle, and keep him three days that he be not ridden and then set on him with spurs and spur him in that place; and then at night wash that same place with urine \& salt and nettles sodden therewith and this shall grieve him sore that he will never abide spurs after; then take half a pint of honey and anoint his sides therewith three times and this shall make the hair to grow and make him whole for evermore.

If you must wear spurs, wear them without rowels, and use them only as a last resort. If you find yourself, like most riders, using them unconsciously in the excitement of the chase, or accidentally when jumping, leave them at home. If your experience is at all like mine, you will say your horse is a far better, far bolder, far safer jumper without them than he was with them.

They are necessary, in military riding, to make a horse dress, or go sidewise to the right or left; but beyond this they are of little value even to the cavalryman. In flat races they simply contract a horse's stride, and have lost more races than they ever won. 
XI

DRESS 
- Buckskin's the only wear fit for the saddle;

Hats for Hyde Park, but a cap for the chase;

In tops of black leather let fishermen paddle,

The calves of a fox-hunter white ones encase."

“A WORD ERE WE START," egerTON WARBURTON 


\section{XI}

\section{DRESS}

THE ETIQUETTE OF THE HUNTING-FIELD - THE OVER-DRESSED THE UNDER-DRESSED - THE SWELL

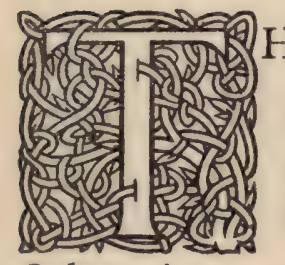

HE laws of dress for the hunting-field are governed by an unwritten code. When the hunting-coat is of pink, then white huntingbreeches, top-boots, and a silk hat are requisite.

Otherwise a grey or dark melton, with or without tops, breeches of any suitable cloth, and a derby or square-crowned derby hat - but never the velvet cap, unless you are an officer or servant of the hunt - are necessary. Do not dress better than you ride. Over-dress marks the swell and the novice, and is decidedly vulgar. At the same time you should be thoroughly well dressed and especially well groomed, keeping rather to the practical and the utilitarian, as if you were out for business, not display. On the other hand, it is equally poor taste to go to the other extreme and ride in shirt-sleeves or without a hat. Such dress, or undress, may be suitable for road riding, for exercise, or for polo, but it is hardly showing proper respect to the Master to present yourself in such attire in the hunting-field, especially when it is a regular meet. On a by-day a little more 


\section{32 Cross Country with Horse and Hound}

liberty may be taken. You had better keep to the safe side, and always be well within the limits of what the Master, by his example, may prescribe.

The hunting-coat should have elastics in the sleeves to shut out the wind. Wear a woollen shirt and a stock tie; the wool absorbs perspiration and prevents discomfort.

Pink is seldom worn in America, except at hunt balls.

As no well-regulated family is quite complete without a black sheep, so no hunt club is quite complete without a swell; and to write a book on hunting and not include this interesting specimen would be a considerable omission. Here he comes now, fresh from his valet, who is likewise fresh from the tailor. You feel like betting ten to one the clothes he wears are not paid for; but no matter: he had to do it. In fact, it was the sight of the latest hunting fashion-plate that decided him to take to hunting. His appearance gives a deal of harmless amusement to the other members. He has choked himself with a stock, and wears a corset, or looks as if he did, in his wasp-waisted huntingcoat. He wears number seven patent-leather boots on a number eight foot. What an unhappy, uncomfortable person he looks! How can he be otherwise with boots too small, coat too snug, stock too tight, and his horse a long-legged, light-waisted, three-cornered animal of the weedy thoroughbred order? Altogether he resembles a gaudy rider in the show-ring. He is, indeed, out to show off. After a good pull or two of jumping-powder from a gold-mounted flask, he is quite fit to make a spectacle of himself. He generally gets a damning from the Master, either mentally or orally, for riding too near 
his hounds, and seems utterly regardless of any rule of hunting.

"Hold hard, there!" shouts the Master. " Can't you see you are driving the hounds off their noses? Hold hard, I say!"

"I wish," he adds mentally, "you and all your kind would take yourselves out of the hunt, and stay out. You do not know the meaning of sport. You are a hindrance and a dead-weight in any hunting-field. For rocking-chair hunting at the club or as an ornament at the hunt ball you do very well, but as a hunting man, never!"

These, or words to this effect, every hunting man has heard the Master say until he knows them by heart. 



\section{XII}

FALLS 
"Rouse ye, my bonny steed, neatly collecting All your strong quarters for a spring;

Thoughts of the danger our senses inflicting, Life may depend upon your stride and your swing." RHYMES IN RED 


\section{XII}

\section{FALLS}

THE ART OF FALLING - LEARNING TO FALL - BAROMETER OF
FEAR - FALLS NOT THE HORSE'S FAULT

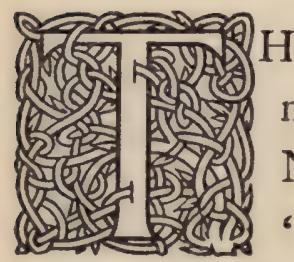

$\mathrm{HE}$ art of falling may be considered as a necessary accomplishment in riding to hounds. Nothing will advance a novice further in the "noble science" than a few harmless falls. It is a singular thing that a man never begins to ride until he has been dumped over his horse's head. From that moment he becomes a rider, whereas before he was only a timid hanger-on, or so hampered by the dread of falling that he could not ride. He finds it is not half so bad as he had imagined. It benefits him in his hands and seat, and, indeed, in every way.

There is a knack about falling, as there is about swimming. No one can tell a beginner how to fall: he must learn by experience. The great thing for the novice is to have had enough practice in riding to save him from losing his head, and then to get spilt often enough to acquire the necessary schooling.

The first few times the novice goes to grass his mind becomes a blank; his head literally is lost. The mo- 


\section{38 Cross Country with Horse and Hound}

ment he finds himself going, fear takes such a hold upon him that he is in a state of catalepsy, and goes through the air and lands in a heap like a dead man. Even the law of self-preservation is gone. Contact with the earth, however, brings him to himself. Some one catches his horse, and he gets up again, none the worse for wear. From that moment he is an altered man. So far from a course of falls making him more timid than ever, he has gained - supposing he is not altogether unacquainted with riding - a great increase of courage when they are done. He rides more easily, more gracefully. His coat, for a few times, may look of the earth earthy, his breeches of the grass grassy, but the dread and horror of being thrown are left behind.

The learner's tuition by means of a series of falls follows a more or less regular course. After the first few tumbles he realises, with varying degrees of surprise or hardihood, that going to grass may be done in divers ways. When, for instance, having recovered from his first state of blankness, he goes again at his fences, he discovers that his horse has picked up the fear his rider left behind, and, thinking another fall is due, refuses to jump. Thereupon out of the saddle goes Novice once more; he was not expecting to fall on the take-off side of the fence. "Good!" comments the experienced spectator, inwardly. " Nothing better could have happened him."

Again the horse is caught, and Novice mounts another time, with courage still rising. The horse, however, has been losing confidence, and feels that his insecurely seated rider is likely to give him another painful jab in the mouth 


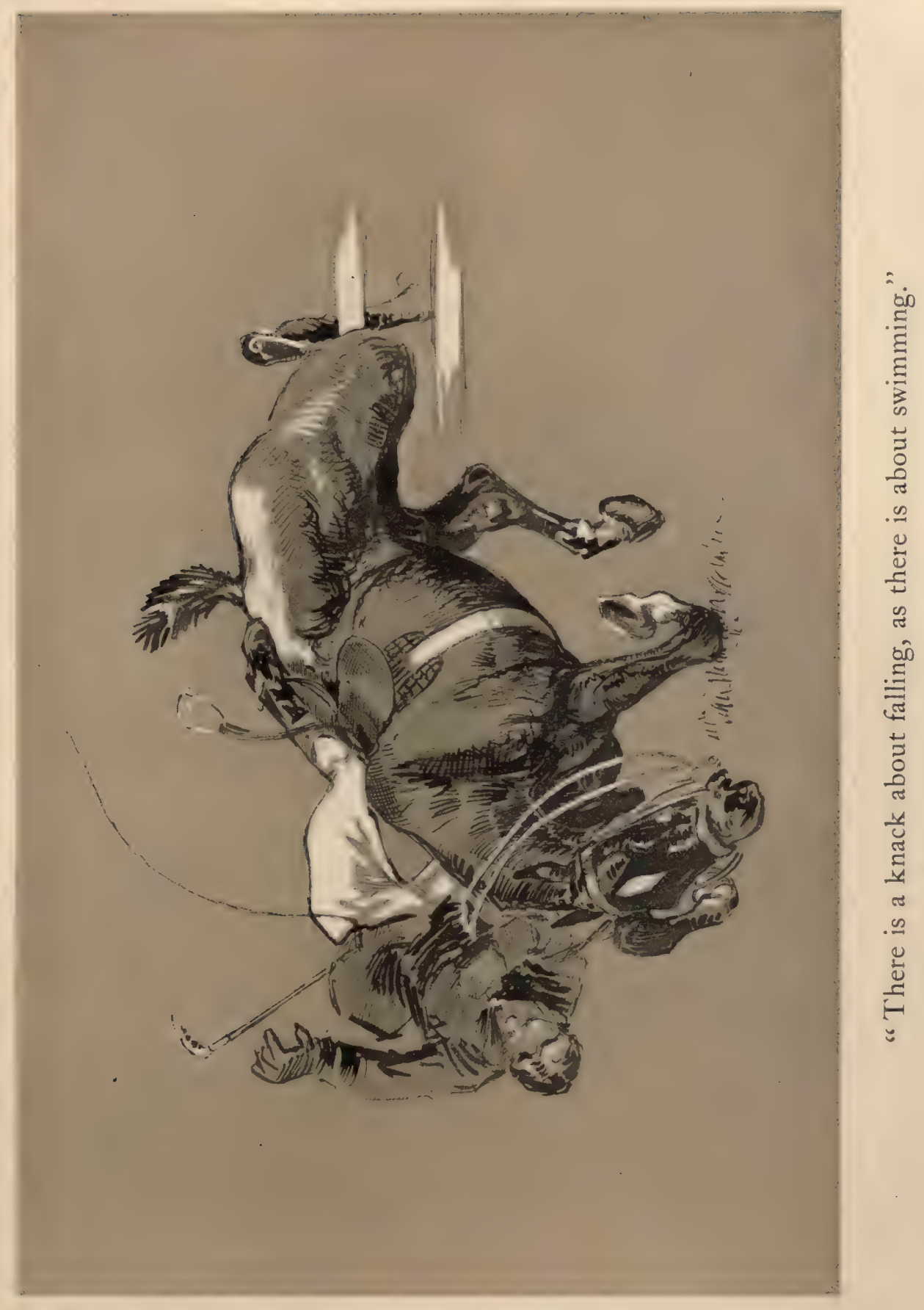



by getting the reins mixed or by holding on by the curb instead of the snaffle; but he is an old hand and does not lose his temper. For a few jumps everything goes beautifully. Novice feels as if his education were complete, and imagines himself startling a field of experienced horsemen with wonder, if not with envy, by his superior horsemanship - sure sign that another cropper is in pickle for him. He grows careless. From riding with timidity, he begins now to keep company with recklessness. "That 's well," says the experienced friend. "One extreme follows another. It 's a natural law." Novice is getting on beautifully. The next header will, in all probability, set him back where he belongs - about half-way between extreme timidity and extreme recklessness, at a place designated cautious-bold or bold-cautious on the cross-country rider's barometer, which may be marked in some such way as this:

(I) Timid extreme ; (2) fearful ; (3) cautious ; (4) cautious-bold.

(4) Bold-cautious; (3) careless; (2) heedless; (I) reckless or "daredevil" extreme.

Presently comes Novice on a new horse. This was not wisdom, but he would have it. The animal, as it happens, has always been a bit hot at his fences, and, like most inexperienced horses, jumps about as high again as is necessary over the first few obstacles. This, Novice is not prepared for, and just manages to scramble back into the saddle from the horse's neck, not without having lost one of his stirrupirons. Novice catches his breath at the unexpected dis- 


\section{40 Cross Country with Horse and Hound}

placement, and his mount, feeling considerably above himself this morning, and taking alarm at this helterskelter scramble on his back and neck, gets the bit in his teeth and rushes away with an idea that there is no one at home. Novice was warned by the groom, but he was riding at "heedless," and what the groom said did not count.

The very first jump, however, sends him back to the "fearful" mark. Now that his mount is running with him, he wishes he had listened. But others are looking on, and he makes no sign. After a turn or two about the field, going at his own sweet will, his mount comes to hand. Novice has lost his hat in the meantime. He looks pale. He does not think so much of crosscountry riding as he did. Somehow his enthusiasm for riding to hounds has nearly oozed out of him. Before this he has talked hunting to every one who would listen, read every author on the subject he could find by day, and dreamed about it by night. He has ordered a new hunting-coat, boots, and breeches. But now he thinks he should prefer yachting.

The groom, bringing him his cap, inquires: "Are n't the stirrups a bit long for you this morning, sir?" - a master stroke of tact. Novice assents as if he had known all the time what the matter was. Meantime there has been a little breathing-spell for the mount, which, having rid himself of the surplus kinks in his back and legs, and feeling somewhat relieved of his supercharge of strength, is now the picture of docility. Novice nevertheless is trying to frame a plausible excuse for sending him to the stable, when some 
one says, "Try him again," and another, "You are not going in, are you?"

“ Not much," replies Novice, in a voice intended to convey a sense of composure and determination.

There is no turning back now. He has burned the bridge behind him. So, with set features, he crams on his cap, takes a good hold of the reins, hardens his heart, and away he goes over.

"Well done!"

"Good boy!"

“Try it again!"

“Beautifully jumped!"

"Perfect form!"

Exclamations of approval greet his half-dazed senses as he comes to a halt before the lookers-on. Now the hand on the barometer points at bold-cautious, and his spirits rise once more. He wishes he had ordered a pink instead of a grey melton for his hunting-coat.

So far his jumping has been confined to timber hurdles between wings built up on a schooling-ground. Another jump or two he negotiates successfully. The colour returns to his face, which is now wreathed in smiles that he can no longer suppress for the tumult of joy going on within him. He proposes to try the bank and ditch, though his groom demurs.

"Why not?" asks our bold rider.

"Well, please yourself, sir. Only send him at it so as to clear the ditch."

It is bad advice too well followed. With too long a start, the mount takes off too soon, Novice thinking he was 


\section{42 Cross Country with Horse and Hound}

going to put in another stride before he jumped. $\mathrm{He}$ is not prepared, is out of balance. His mount catches a knee on the bank, ploughs a hole through the top of it with his hind legs, and horse and rider are both in the ditch.

"Nothing better could have happened," reiterates our experienced rider as he sees the mount racing for the barn and Novice brushing the soil from his clothes before he is fairly on his feet. "Don't give up defeated."

"Not much," says Novice, with chattering teeth.

"At it to within the last few strides," advises the experienced friend, " and mind he does n't refuse with you at the last moment."

It is timely advice again, for refuse he does, and Novice shuts up and opens like a jack-knife while going through the air. He lands, however, on all fours across the ditch, while his horse stands with his feet braced against the bottom of the bank. The law of self-preservation has stood by him, and he saves himself a bad jar, if nothing more, by landing on his hands and feet and scrambling on out of the way of his mount should he be turning a somersault after him.

Novice's history is typical. During the first falls reason and instinct disappear. The ground comes up and hits one in the face. The time between leaving the saddle and landing is a blank. Fear cuts off all the faculties. But after a few croppers without serious injury, fear has less hold. Self-preservation begins to work. One falls semiintelligently, even retaining presence of mind enough to hold on to the reins and take them along over the horse's 
head in a neat and workmanlike manner. And when one can do this he knows how to fall.

I doubt if any one can retain entire presence of mind throughout a fall. As we feel ourselves going, reason deserts us. When we come to our senses again we find that a kind of second mind has acted in the interest of self-preservation, under the influence of which we have clung to the bridle-reins or scrambled the length of ourselves to get from beneath a possible somersault of the horse.

Some say never part company with your horse until the last moment, when he is surely down. I cannot agree with this counsel. I believe it is the better part of valour and of horsemanship to part company with him the moment you feel that the chances are he is going down. Of course your horse may recover and you might have saved yourself the inconvenience of mounting again, but it is better by far to clear out while you have the power of self-preservation to go with you, and land on your hands and feet, than to be an instant too late and so be carried under your mount. You will go to grass oftener perhaps by adopting this plan, but it is better to throw yourself off than to wait until you are thrown off. No one can tell you how this is done; instinct only can direct. Ride by balance, give yourself up wholly to the law of self-preservation, and instinct will do the rest.

It is safe to say not one fall in a thousand is accompanied by injury; and that the greater number of falls are the fault of the rider there can be no doubt. Nine times out of ten a horse goes down because he is thrown by the rider, either 


\section{44 Cross Country with Horse and Hound}

from the rider's being himself out of balance or throwing his horse out. Think, after all, what an easy thing it is to overbalance a person when he is not on both feet. A sudden swerve of the rider's body sideways in mid-jump will be sure to land his horse with a fall or a scramble to regain his footing. Similarly a lurch of the rider's body backward at the take-off retards the action of the horse and makes him jump short, so that even if he clear the obstacle with his fore feet his hind legs are caught on the fence. Again, by an improper seat, if the rider's body lurches heavily forward as the mount lands, the horse is thrown on his head and a somersault is the result. On the other hand, when a horse is given perfect freedom of rein in clearing an obstacle, and his rider sits him by balance, a spill is wellnigh impossible. 


\section{XIII}

COURAGE VS. FUNK 
" At the fall of the year, when fair autumn is here And the glories of summer are fled,

When the evenings are long and the breezes are strong, And the leaves in the covert lie dead-

Then, then is it time to our saddles to climb, And in scarlet ourselves to adorn, To welcome our sport of the old-fashioned sortTo follow the hounds and the horn." 


\section{XIII}

\section{COURAGE VS. FUNK}

TRUE AND FALSE NERVE - CATALEPTIC RIDERS - PREPARATION A CASE OF FUNK THAT REACHED COLLAPSE

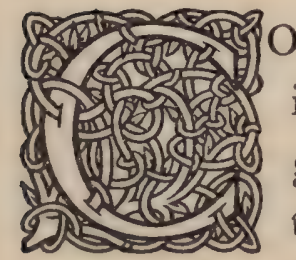

OURAGE is a product of nerve. Nerve is the result of health. Health comes from good nutrition, and nutrition depends upon the stomach. The best way to produce courage is to cultivate good health. The best way to cultivate good health is to take plenty of exercise in the open air. The best way to accomplish this is to ride horseback. A torpid liver makes a mountain of an ant-hill; a stout stomach makes an ant-hill of a mountain; and no matter what the obstacle is, it is only what it looks to be.

The one great thing in the way of a horse's education and of successful cross-country work is fear. The way to subdue fear in a horse is by confidence. The way to overcome fear in a rider is to keep the body in a healthy condition. Weak, shattered nerves are a fruitful source of fear in man, and a horse's natural timidity makes it easy to transmit fear to the horse. Anything the rider can do or not do to strengthen his nerves will likewise strengthen his courage and the horse's. If tobacco irritates his nerves, he 


\section{48 Cross Country with Horse and Hound}

had better stop using it. If spirits excite them to a tension that leaves them more languid and unstrung than before, he may know by that sign that these things also are a hindrance.

A run, sir, will please you far better than wine;

The farther you gallop, the better you 'Il dine.

It is a lamentable sight indeed to see a man with nerves so weak that he must needs get half drunk before he has nerve enough to ride to hounds. I am not going to preach, but simply to caution. Stimulants of any kind,- except exercise, fresh air, wholesome food, and sound sleep,while they may produce a temporary effect, only make a man's nerves weaker than they were before. It is really a nauseating sight to see a man in the hunting-field "getting his spirits up by putting spirits down," open confession as it is of weakness, fear, and funk.

There are all degrees of courage. Bravery and courage have a common ancestry in nerve. Recklessness, heedlessness, and daredevilry, on the contrary, are born of foolhardiness, which is the utter absence of courage. Some men and more women, I believe, perform feats in the hunting-field which pass for nerve or courage, but which, when we come to analyse them, we find due entirely to the absence of these qualities. There can certainly be no courage where no danger is felt or seen; nerves that are insensible to pain are not nerves.

That many men and women ride to hounds with courage and nerve in a sort of cataleptic state, there can be no 


\section{Courage vs. Funk}

question. On the field of battle, it is said, men lose all sense of fear and do things that seem wonderfully brave and courageous, when the truth is that they have passed, for the time being, beyond the effects of fear or courage. Men frequently do things in an apparently cool and natural way while what we call nerve is - instead of being active simply in abeyance. Women do many heroic things the very thought of which, when their nerve and courage return, is enough to make them faint.

Some persons, especially nervous people, ride to hounds in a similar state, particularly when in the act of jumping. They send their horses at a fence " neck or nothing," and are regarded as brave and courageous, when the fact is they could not have taken it coolly if they had tried. In other words, it is a case of fear. The same is true of a cowardly horse. He rushes neck or nothing over his fences as he would rush a steam-roller. The rider rushes his fences as he would rush a crazy man firing a revolver at random. It is fear pure and simple, but it is often called courage. Horses and riders of this sort go into a trance; that is, they sense the danger to a certain point, just as a soldier dreads and fears the bullets until the first round is over and he passes beyond fear. It is well known that a criminal who breaks down utterly at the thought of being hanged will, when the hour comes, walk out upon the scaffold with more composure than any person in sight. We call it courage in the face of death. It is neither, but a provision of a kind Providence to rob him, for the time, of all sense of fear. The really brave man, the truly courageous horse, is one who knows the danger, who realises as clearly and 


\section{50 Cross Country with Horse and Hound}

knows as distinctly what he is doing at the moment as he does afterward in looking back upon it.

Hardly less important than presence of mind are foresight and preparation. A business man, or a person of sedentary habits, who found he did not enjoy last season's hunting until the very last few days, was probably unprepared for it. One ought really to begin a month or more before the season opens to condition one's self and fit one's self out. The sooner a person learns that this and strength of nerve alone enable him thoroughly to enjoy hunting, the longer and keener will be his pleasure. "There is no use," many men have said in the States, giving up hunting after a year or two, "in punishing and goading one's self into a pastime in which a man is tortured with fear." The trouble is that they go to the hunting-field with no preparation beyond closing their offices and packing their kits. It is hardly any wonder that they go in fear and trembling, nerved only by friends and lookers-on.

When you stop to think about it, you would not ask a horse to go through a day's hunting after he had been running about in a farm-yard all winter. It would be absurd. You have him taken up six or eight weeks at least before the opening of the season, and fed and groomed and exercised until he is as hard and fit as possible. Indeed, when you come to mount him you may find him so much above himself that your nerves begin to quake; you have to resort to stimulants. Even then, possibly, you ride him only a few miles and return home completely exhausted. A pack of hounds could not run far with no more physical exercise than you have had for the last eight 
months. They could not catch a fox if he were "hoppled." Certainly not, you say; no one would dream of such a thing. Yet it is what many men do for themselves in their own cases.

The season opens October I. By July \& kennel work begins. It is walk, walk, walk, and trot, trot, trot, every day a little farther. Even the foxes have been bustled about for a month to make them give a good long chase. Your mount is fit. Everything and everybody is ready and thoroughly prepared for the chase, excepting you for whom all this preparation has been made, the one of all the group who should be as fit himself as is the horse he is going to ride or the hounds he expects to follow.

Every season brings to the Genesee Valley and other hunt clubs a score or more of soft, nerve-sick men, who expect to begin riding to hounds the next day, without having lifted a finger toward conditioning themselves. Lamentable sights indeed they are to the natives and the conditioned men who come out to join them. We have seen them at covert-side, when waiting for the whipper's-in cry of "Tally-o, gone away!" and the huntsman's rallying cheer "Edawick, Edawick!" actually speechless and but little short of collapse. Their faces are as pale as ashes; their supercharged horses only add to their unhappiness. I remember one case in particular of a gentleman from Boston who was a guest, for the week, of a Mr. H_and who had that morning arrived, with only time to dress before the hour of the meet came round. His mount had been sent on ahead. The guest was a fine, large, upstanding man, a little on the corpulent side of life. He 


\section{52 Cross Country with Horse and Hound}

had ridden in the valley the year before, and, while he was not a "threshing scoundrel" of a rider, had acquitted himself fairly well. But this morning evidently his nerve was gone. He trembled so he could hardly get into the saddle. His host had mounted him on his old trustworthy Billy Claffy, as honest an old hunter as ever laid a foot to grass, whom nothing could make do wrong. He was as sober-going as a deacon passing the Sunday plate. Now it so happened Billy's rider and I came alongside of each other on the way to the covert. I spoke a few words to him, but he could not answer for a moment. Finally he faltered: "I am going to fall off at the very first fence."

"Nonsense!" said I, reassuringly. "With Billy Claffy you are as safe as if you were in a trundle-bed with your own mother to rock it."

But, sure enough, in jumping over a three-rail fence on the way to the Hartman flats, off went the guest like a quarter of beef. Co-chug! he landed on the grass in a sitting posture, with one foot sticking through his new silk hat. It was about the most laughable sight I ever saw. The fall seemed to daze him for a moment; then, recovering himself, he cried out: "Catch my horse! Here, somebody! I say, there, catch my horse!"

Billy Claffy, all the while, was not the length of himself away, quietly eating grass. This was the end, so far as I ever knew, of this gentleman's riding. It was a case of funk that reached collapse, and all for want of a little preparation.

In another field of sport we see similar cases every year in the woods of Maine and Canada. The typical city man 


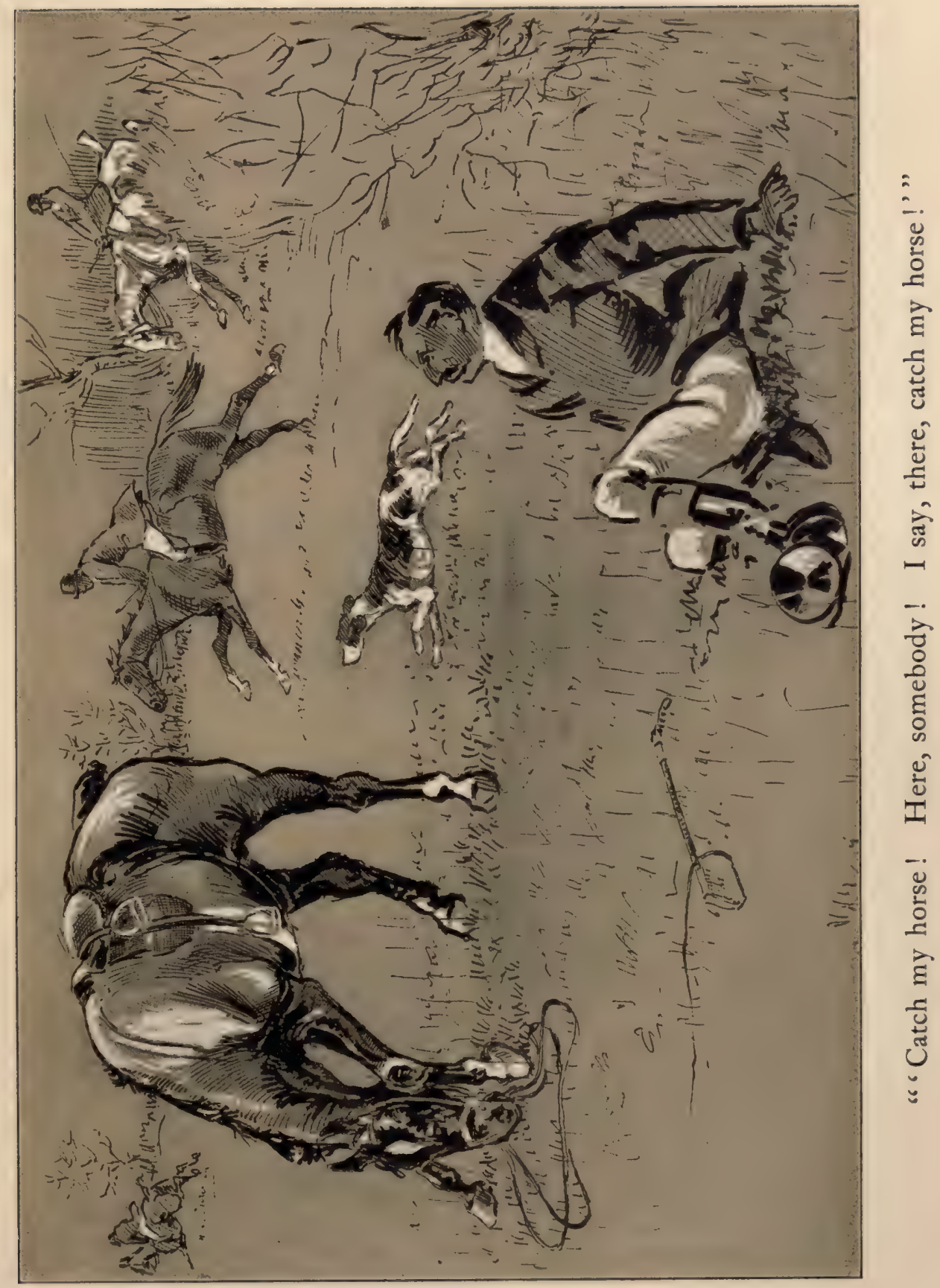



goes shooting, following, or trying to follow, a guide over rough ground, when he has not walked more than quarter or half of a mile a day for a year. When he comes home he has a fit of sickness and is more in need of a vacation than when he started.

How shall you prepare yourself? First shut down a bit, if not altogether, on tobacco and liquors. Take one Turkish bath, or possibly two, a week, if you are carrying too much fat. Begin with Indian clubs or dumb-bells at home, if you cannot go regularly to a gymnasium, and work moderately, say for one hour, with frequent resting and afterward a cold spray before you go to bed. Repeat the exercise and shower next morning before dressing for the day. Increase the exercise until you can do two hours at night and at least one in the morning, and in addition walk to your office, or as much of the way as possible, and back again. For the reasons already given in the chapter on "Seat," in the passages speaking of riding by balance and of the law of self-preservation, fencing or boxing would in all probability be the best possible exercise for you. There is no indoor sport like fencing. It trains the nerves, quickens instinct, and developes every muscle in the body. There is nothing better suited to a man after his college days are over.

Without this preparation, or something like it, your vacation will end just where it should have begun. Fit yourself to be a suitable companion to your mount, and he will give you such a month of sport as will keep your blood tingling for a year to come. I cannot convey to you by any words the great gulf there is fixed between the man 
I 54 Cross Country with Horse and Hound who goes to his vacation fit and the one who is not. Try both ways and see. A horse above himself with "overfit" and a man beneath himself with "under-fit" make about as unsociable a couple as ever come together in the hunting-field. 
THE HOUND 
"So model thou thy pack, if honour touch

Thy gen'rous soul, and the world's just applause.

But above all take heed, nor mix thy hounds

Of diff'rent kinds; discordant sounds shall grate

Thy ears offended, and a lagging line

Of babbling curs disgrace thy broken pack."

SOMERVILLE 
XIV

\section{THE HOUND}

STANDARD OF EXCELLENCE - DRAFTING FOR FAULTS - AMERICAN AND ENGLISH HOUNDS COMPARED

HE foxhound has attained his present degree
of perfection after two hundred years and English masters of hounds, generation after generation, to produce the highest standard of utility, combined with beauty and symmetry of form, colour, and markings, the nicest balancing of tongue and nose, and the utmost uniformity in pace, that these and the dozen other qualities that go to make a perfect hound have been achieved. There is no animal in the world, not even the horse, that has had such attention paid to its breeding as the foxhound has had in England. Few families can show an unbroken pedigree of such length as may be traced in those of thousands of foxhounds, and, when it comes to breeding, equally few in the nation can produce such purity of blood and such an untarnished escutcheon as the foxhounds of the present day in England. Indeed, there is none in the whole list of domestic animals whose standard of excellence 


\section{r $5^{8}$ Cross Country with Horse and Hound}

can be compared with that of a hound. The foxhound is the only animal of which it cannot be said

One genius will but one body fit;

So wide is art, so narrow human wit.

In cattle and horses, as in all other domestic animals, one quality beyond symmetry and beauty is about all one breed can be asked to develope. Occasionally a zealous breeder will set up a claim that his breed of cattle is superior in two points of excellence, as, for instance, in both butter and milk, or in both beef qualities and in milk. Such animals, however, cannot compete with either the trained dairy or the trained beef breeds. Some breeder of sheep may set up a claim that his particular breed of sheep is superior for both wool and mutton. Such sheep, however, are in the one case always beaten at a sheep-shearing contest, and in the other, again, in competition with a mutton breed.

To say of a horse that he is good for speed and draft means that he excels at neither.

One breed of dogs may be noted for its beauty, another for its symmetry, another for its grace or uniformity in colour and markings. The English foxhound is the equal, if not the superior, of any family, however distinguished in any one particular. As to endurance and muscular development, nothing approaches him. The Duke of Rutland's champion stud-hound Belvoir Dexter measures eight and a quarter inches around the forearm, and is muscled throughout in proportion. In general hunting ability a foxhound possesses the fling and drive of a pointer and the speed of a race-horse. He has the keenest of noses and the most musical of tongues. Indeed, there is 
not a single desirable quality to be imagined in a dog that he does not possess; not a single attribute of an ideal hound for hunting hares, foxes, or deer that he has not had bred into him. Yet, wonderful as it is to find so many qualifications in a single animal, they are but the foundation of what an English breeder is satisfied with for his pack. A first-class pack of hounds consists, on an average, of fifty couples. Any man who has had experience in breeding pointers or setters knows what it means to grow a single pair of dogs that work properly together after birds; what, then, must it mean to produce a hundred hounds "with but a single thought"?

For a description of an ideal English foxhound we cannot do better than call on Somerville as follows:

His glossy skin, or yellow-pied, or blue,

In lights or shades by nature's pencil drawn, Reflects the various tints; his ears and legs, Fleckt here and there, in gay enamell'd pride, Rivals the speckled pard; his rush-grown tail O'er his broad back bends in an ample arch; On shoulders clean, upright and firm he stands; His round cat-foot, straight hams, and wide-spread thighs, And his low-dropping chest, confess his speed, His strength, his wind, or on the steepy hill, Or far-extended plain.

The following imperfections would draft a young hound, no matter what his other qualities might be : a coarse head; a head lacking in character; a short neck; a throaty neck; a slackness behind the shoulders; a weak loin; a stern set on too low or not properly carried; a narrow chest; legs lacking bone; crooked legs; weak joints; large flat feet and long toes; defects of colour or markings; a lack of general robustness. 


\section{I60 Cross Country with Horse and Hound}

Any one of these defects is almost certain to draft a hound without even a trial in the field. Passing the examination for these defects is like passing the masonic " first degree." Out of one hundred puppies that come in from their "walks" from thirty-five to forty per cent. are thus drafted, and of these first-draft youngsters some are killed at once. In doing this, to be sure, the huntsman or master may be destroying some of the best working hounds of the pack, or the best in breeding, and it takes a bit of courage to kill a fine upstanding youngster because he is badly formed in some essential. Occasionally a drafted hound of very superior breeding is given a chance of a field trial; but he is half doomed to start with, and unless he should prove himself something above the average in field work, he would be the first to go in the second draft.

It would seem that after hounds had passed such rigid examinations as the above they were entitled to admission without more ado. The hardest examination, the supreme test, however, is still to come. The first draft was by a standard of "Handsome is that perfect is." The second test is "Handsome is that handsome does," and elevates the candidate from a dog to a hound. The hound that is finally found good enough to become a member of this most aristocratic family must be :

Not too tall or too short; *

* Twenty-three or twenty-four inches is the standard. If a hound is over that he is classed as a staghound and is in demand for packs that chase the stag or hunt the wild deer. If below that standard he finds his way into the harrier packs. The beagle hounds are still smaller than the harriers, and are used to hunt the hare or foot. They are nevertheless members of the foxhound family, the difference being principally in size. 
(x) Neither too slow nor too fast;

Not too free in giving tongue.

(x) He must not give too little; a hound that runs mute is killed without further delay, and so is a confirmed babbler.

He must not be a line hunter - one that insists on following with his nose the very track of the fox.

(x) He must not be a skirter, or one that runs too wide and is content to let the other hounds do the hunting; he must be a worker in every respect and not a hanger-on.

He must have a melodious voice, neither too high nor too low; of such a pitch, that is, as makes no discord in the melody of the pack.

(x) He must never tell a lie by giving tonguẹ to a line until he is absolutely certain.

(x) He must not take to running the scent or line of any other animal. A hound that is at all given to running riot has the death-warrant read to him, with little chance of a reprieve.

A cross $(x)$ in the above enumeration means that for a defect in that particular the sentence is death. Hounds that fail in this second test go out in what is called the second draft, and are usually sold for a nominal sum to form the nucleus of some foreign pack, or to some neighbouring pack which wishes to obtain good blood for a little money.

By the time the second draft is completed, fifty per cent. of the year's crop of puppies have been weeded out. This does not take into account the distemper, a malady to which, of course, all are subject and of which many die.

Next comes the third degree. The requirements are 


\section{Cross Country with Horse and Hound}

quite as rigid as in the first and second degrees. The hound must prove himself to be:

Neither quarrelsome nor timid.

Neither slovenly nor too fastidious.

Neither a glutton nor a poor feeder.

Neither sulky nor quick-tempered.

Neither too meek nor disobedient.

Having passed this critical test under the watchful eye of the kennel huntsman, who has little indulgence or inclination to excuse, and being thus duly and truly prepared, the dog is permitted by the master to pass into the inner court, the holy of holies, as master workman, with the enviable distinction of being thereafter styled a thoroughly qualified foxhound.

We have gone in some detail into this question of standard and of drafting for two reasons: first, to show the novice the almost priceless value of a hound; and, second, to set an example that may elevate the standard of houndbreeding in America to the position it holds in England.

In the States the rule is "Handsome is that handsome goes"; and everything goes. Generally speaking, the hound is looked upon as a dog. To speak of a hound in England as a dog would offend quite as much as it would in America to call a well-bred dog a cur. Americans are very clever, as a rule, in "catching on" to any new enterprise; but the art or science of breeding domestic animals for improvement is not, as a rule, one of their accomplishments. There are, however, a few masters of hounds in Canada and the United States who have caught the spirit, the fascination, the great pleasure, there is in the art and science of breeding. Let 
us hope the ambition which Mr. Thomas Hitchcock, Jr., has for his pack of pure-bred American hounds at Aiken, South Carolina, to mark out a line of improvement toward a higher standard, will meet with the unqualified success it deserves. It is a most sportsmanlike undertaking. The most he had to start with was a nose and a musical tongue.

For the most part the so-called American hound is a sort of nondescript dog, without a standard. American hounds, which are all more or less of bloodhound extraction, are certainly very well adapted to hunting the hilly, rough country, the ploughed and sun-baked fields generally, of their native land. They are most methodical, painstaking, and plodding, and seldom fail, if they can follow the trail at all, to account for the fox.

They are well enough, that is, so far as they go; but fox-hunting is not simply the killing of a fox. A homemade snare, a rat-trap, or a bit of "rough-on-rats" would do that much with far more ease and despatch. Whoever has ridden to a nondescript pack of hounds, in which absence of any kind of uniformity is the chief characteristic, and has afterward followed a pack of up-to-date foxhounds in England, will have marked such a contrast as will forever after prevent him from repeating what one so often hears in America: "I don't care what a hound is like, as long as he can hunt!"

An erroneous notion is current among hunting men in America that in some way symmetry and beauty are antagonistic to utility, and that the American hound is better, if anything, than the English. It must be admitted that there is some excuse, if no reason, for this belief. When Ameri- 


\section{I64 Cross Country with Horse and Hound}

cans send abroad for hounds they are invariably selected from the fashionable racing packs of the great grass countries. These hounds have symmetry and beauty and the speed of greyhounds, and for their own particular country are the best in the world. An American hound might well think himself nothing but a cur in such company, and would be left hopelessly behind in the second or third field. The trouble is that in the beautiful grass countries, with their prevailing moist climate, the scent of a fox lies so well that a hound with half a nose can follow it at full speed. Brought to the States and asked to follow a line over sun-parched fields and fallow land, he is more often at fault than an American hound; yet the fault is not with the English hound, but with the locality from whence he came. There are many packs in England where far more suitable selections of hounds for America could be made than those which come from the grass countries. I mean such packs as hunt the more barren and hilly lands, in which conditions as to scent are similar to those of the States.

Whatever is done, Americans should not be content longer with "Handsome is that handsome does." Let them preserve untarnished the sport of the game, and not lower the hunting part of it to the level of a rat-trap. If it is merely a question of getting across a lake, take a ferry. If it is a question of sport, take a sail-boat. You may need more time, but you have the satisfaction of doing the thing in a sportsmanlike way. 
XV

HOUND BREEDING 
"See there, with countenance blithe, And with a courtly grin, the fawning hound

Salutes thee, cowering; his wide-opening nose Upward he curls, and his large sloe-black eyes Melt in soft blandishments, and humble joy." 


\section{HOUND BREEDING}

ORIGIN OF THE BREED - DIFFICULTIES IN THE WAY - THE SKILL OF ENGLISH BREEDERS - MATING AND BIRTH

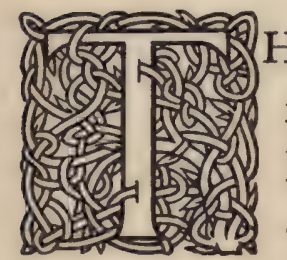

HERE is much discussion among houndfanciers as to the origin of the foxhound, historically speaking a new family, the result of cross-breeding, or out-crossing, from the bloodhound. All authorities agree that the bloodhound is the ancestor on one side. As to the other, opinions differ. Most writers say the out-cross was with the Southern hound, himself an offshoot of the bloodhound. There are many things about the present-day foxhound, as well as the bloodhound, that suggest the greyhound. Both the greyhound and the bloodhound, for instance, are known to be of ancient family. The characteristic of the one family is great speed; of the other, superior olfactory powers. The former pursues its game entirely by sight, the latter depends entirely upon scent. Originally hunting in England was done with hounds that had special individual propensities. Some were used to hunt in cover, while those that hunted by view were used in the opening. "The horn," says Cecil, in "Records of the Chase," "was used indiscriminately to call them together." 


\section{68 Cross Country with Horse and Hound}

Probably the bloodhound and the greyhound were used together, each for the special work in which the other was deficient, as a stalwart blind man might carry a cripple who could see to guide him. It would therefore be a natural step, since one hound could hunt only by sight and the other only by scent, to cross them with a view to combining the superior ability of each. Another bit of evidence to be found in Cecil is the passage in which he says the dogs were "crooked-lean, coarse-haired, with heavy eyes and of a tan colour." This is the description neither of a greyhound nor of a bloodhound, but of some cross-bred animal of the two families, having the "crooked-lean" of the greyhound type, with the "heavy eyes" and "tan colour" of the bloodhound. But even if this evidence, and more of the same sort, were entirely lacking, there are most unmistakable traces in the English foxhound, as he stands to-day, of a strong dash of the greyhound as well as of the bloodhound; compare the pictures opposite.

The greyhound is described in a very old couplet which comes as near being a description of an English foxhound of to-day as would be a description of a contemporary bloodhound. The "neck like a drake's," "back like a beam," the great depth of chest, the shortness of the joints below the knees and hocks, not to mention speed, undoubtedly are points common to the three species. English breeders have not only preserved in the foxhound certain distinguished features of the greyhound, but they have also developed in him certain characteristics of conformation peculiar to him and to no other family or race of dogs. It is sufficient to mention the wonderful increase of bone, the 

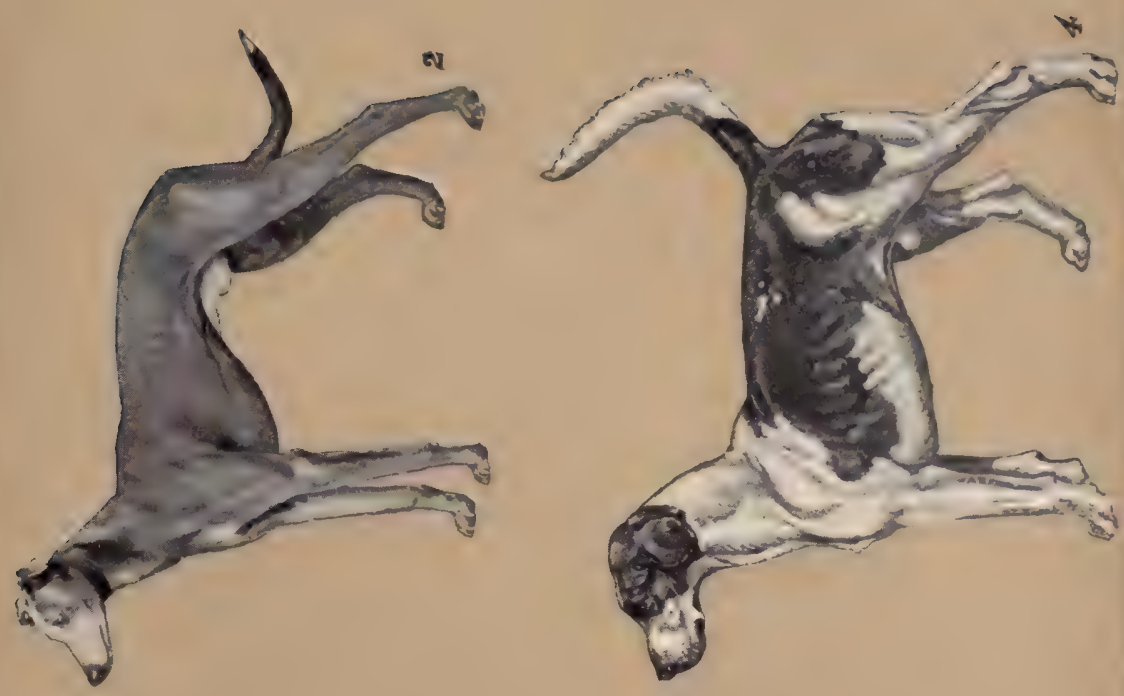

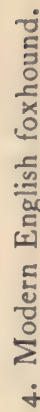

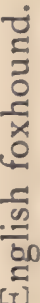

-

ㄴ

ฮี

范

<

$\dot{\pi}$
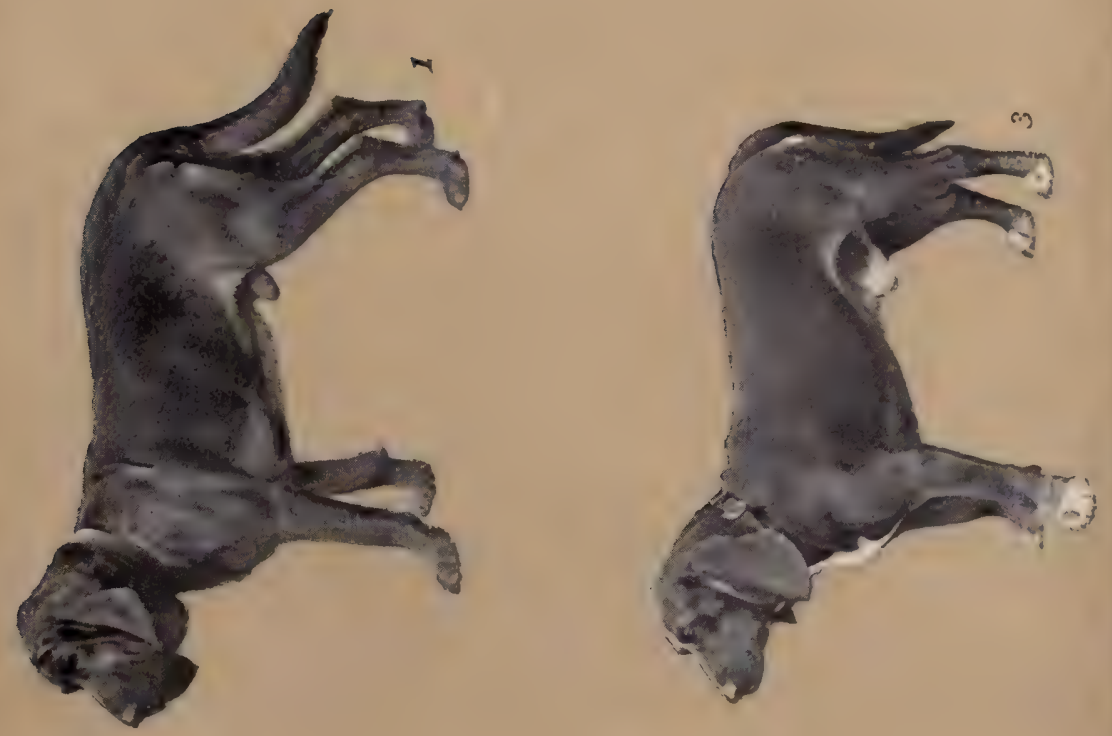

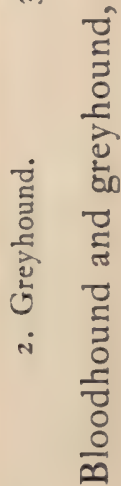

$\frac{0}{5}$
0
$\frac{1}{0}$
0
$\frac{0}{0}$
-0 

straightness of the fore legs, and the shape of the feet. They have succeeded also, as will be seen in the pictures of foxhounds in this volume, in preserving the head-carriage and the neck of the greyhound, the latter as much smaller in proportion to the size of the foxhound's body as the legs, especially the fore legs, are enlarged. This, again, shows to what a wonderful degree of comeliness and utility these animals have attained. Altogether I reaffirm my belief that the English foxhound is the most wonderful example of the art of breeding for improvement anywhere to be observed.

It is by no means easy to produce a new breed of domestic animals, even under the most favourable circumstances. We may cross two families of dairy cattle, or two families of beef cattle, or the thoroughbred with the standard horse, with a view to producing a new family; but it would be considered madness and a waste of time to attempt to form a new breed by crossing a thoroughbred with a clydesdale. In crossing families of similar tendencies, the first cross often produces a very useful animal; after that what the two families have in common will be their original inferiority. The improvements developed in either family through fifty or a hundred or hundreds of years disappear. A clydesdale and a thoroughbred would not mix or blend any more than oil and water would. The greyhound-bloodhound cross must have been quite as rank an out-cross as a thoroughbred-clydesdale cross, and many times more difficult. The greyhound, entirely deficient in nose, and the bloodhound, depending on nothing else, - the slowest and the fastest, the loudest, deepest-mouthed, and the most silent,- 


\section{70 Cross Country with Horse and Hound}

it is impossible to imagine a greater gulf to bridge. Theoretically it sounds most desirable; in practice it must have been the hardest task ever undertaken. How disappointing the results may have been all the way down the line we may never know, but that the English have fought it out is to their highest credit. I say " fought it out," but the battle indeed is not yet finished. It is not at all infrequent, even at the present day, to have a hound cast back with such marked characteristics of the greyhound in one case, or of the bloodhound in another, as to disqualify him as a foxhound entirely; nor are such examples of atavism uniform in certain mothers, for puppies of the same litter often display the opposite characteristics of the original progenitors. One puppy is drafted for being too slow and painstaking, another for being unable to follow the line, another for being too free of tongue, and still another for being mute.

Constant tendency to revert to one parent or the other of course makes all cross-bred breeding most difficult. Mr. Peas, in his excellent work "Hunting Reminiscences," says it probably is within the mark to say that a Master who raises sixty or eighty couples of puppies thinks himself fortunate if out of the number there are ten or twenty couples that come up to the standard at which he aims; and that out of this he can hope only now and again to find a couple fit to win at the Peterborough Hound Show.

Some Americans - usually, I believe, the men who have tried and failed - scoff at what they call "fancy breeding." The trouble is, they have failed almost entirely to grasp the nature of the problem.

For the best stud-sires Americans have paid to English 


\section{Hound Breeding}

breeders millions of dollars, simply for the thing so many of them scoff at - style and beauty. "Fancy breeding" indeed! Five thousand dollars are paid for a bull, ten thousand for a horse, when a bull of equal weight could be bought in the States for fifty dollars and for two hundred dollars a horse that could draw as large a load. A five-dollar dog could bark at a squirrel quite as well as one that cost five hundred dollars in England. The high prices are for style, symmetry, beauty. One may shout, "Handsome is that handsome does," until he is black in the face. Simple utility in anything is a matter of pennies. It costs dollars, and hundreds of them, to buy style and form and beauty. There is no use going to England for the best pack of hounds in that country if a man does not appreciate what it means and has cost to produce them. They would only deteriorate on his hands. England may be slow and behind the times in some respects, but in the art and science of breeding she is two hundred years ahead of America. In the last few centuries there have been developed in England half a dozen or more new and distinct families of horses, cattle, sheep, swine, poultry, and dogs, while in the States there are only the standard bred trotter, produced more by accident than by design, and the "American Dominion" hen, which latter, I am informed, is now well-nigh extinct.

It may sound unpatriotic to say all this of one's own country, but the writer's great desire to see American breeders generally, and American masters of hounds in particular, take hold of this question of breeding for improvement on a plane level with their intelligence must be his 


\section{72 Cross Country with Horse and Hound}

excuse. Any one can breed curs: only an artist can turn out hounds that year after year are more and more symmetrical, beautiful, and fitted to the special purposes for which they are intended. I would hear no more of this "Handsome is that handsome does," but insist upon it that American hounds should be as perfect in build and beauty as their noses are true to the line. The beauty of hunting, what most captivates and keeps one at it, is the manner and style with which the hounds unravel the line. It is the neatness and despatch, the fling and drive with which they follow their game that one most enjoys, especially so if to all these good qualities there is added beauty - uniformity in size, colour, and markings.

In the breeding of hounds the question of right mating is a very interesting one. Most masters take great pains and give special thought to the problem as to which of certain stud-hounds should be used on certain bitches. The question of pedigree has to be gone over carefully to avoid inbreeding. The faults of the bitch must be corrected in the selection of the sire. Forrester is a grand stamp of hound, with the best legs and feet, but he is lacking in freedom of tongue; he is selected to be coupled with Mistress, who, although not a babbler, loves almost too well to hear the music of her own voice. Forrester cannot be used on Bluebells, because his sire, like hers, was, although not a skirter, in the habit of running wide. For Bluebells the best line hunter of the pack is selected to prevent the return in her descendants of the faults of her sire or grandsire. Quickstep, although a model hound herself, was sired by a hound whose puppies turned out weak in the lower 


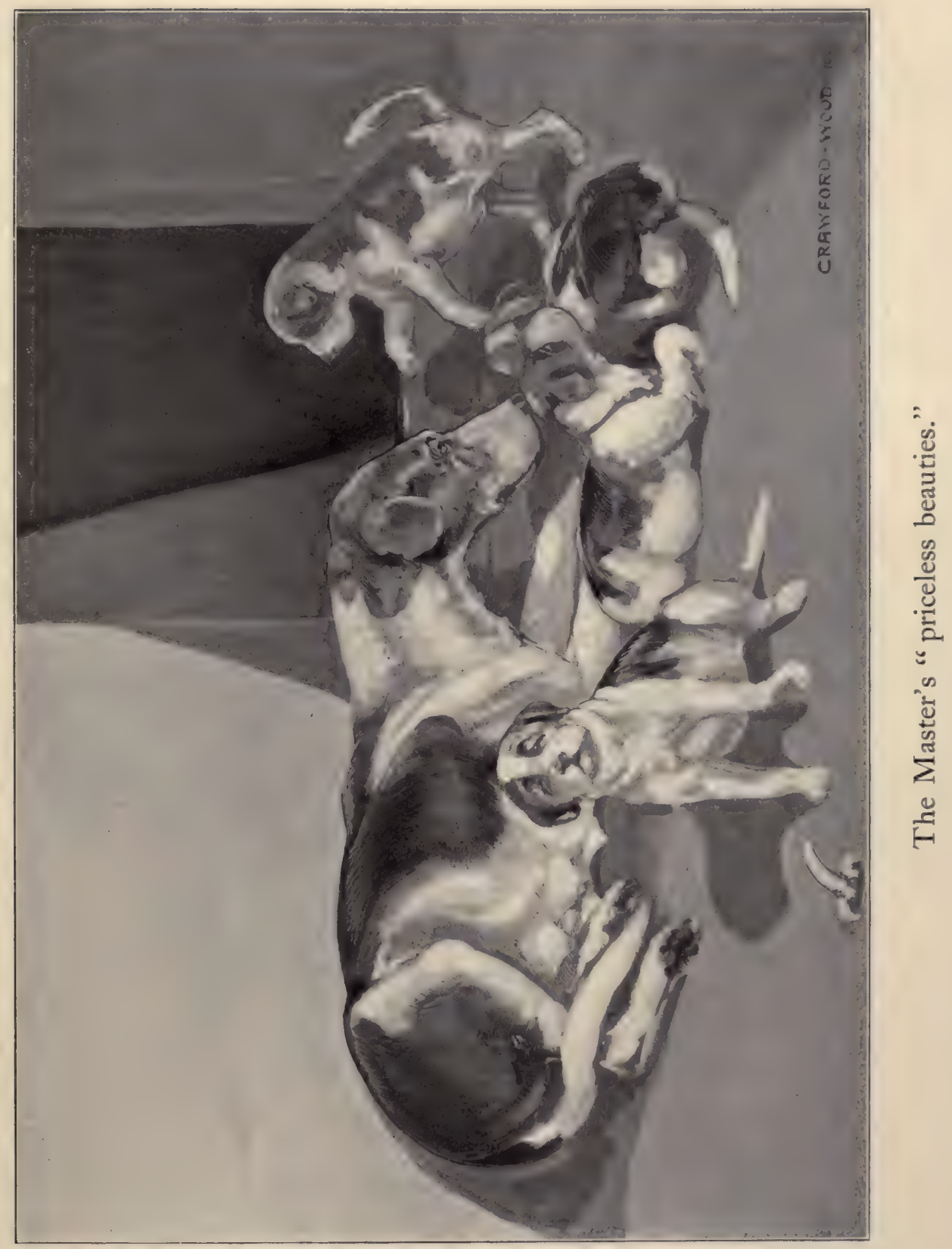




\section{Hound Breeding}

joints. In order to stamp out that serious defect, Sampson, quite a faulty hound in some respects, is selected because in bone and straightness of legs he is nearly perfection. Brightlight cannot be coupled with Overton, who would suit her in every respect except that they both have rather large feet. Thus we might go on enumerating combinations without end.

Then, aside from producing hounds with the straightest legs, the roundest cat-like feet, the deepest chests, the stoutest shoulders and loins, the best of tongues, and the greatest fling and drive, there must also of course be the most delicate noses. The most difficult problem of all is to breed hounds with size and at the same time with quality. The suggestions made in the chapter on breeding horses may be applied here with equal benefit.

Enough has been said to show what it means to produce a perfect hound and to give an idea of the value and interest the Master and huntsman must have in every puppy considered good enough to come out in the yearly entry. I have lingered a bit on this subject in my anxiety to acquaint those unfamiliar with the life of a foxhound with something more concerning his history. I desire that when my supposititious novice finally comes out to hunt he may appreciate the animals he is riding after as well as the one that carries him, and somewhat share the Master's and huntsman's feelings in regard to what they call their " priceless beauties." Besides, it will add much to his interest in the game.

Now let us hark back to the kennels. The whelping season is approaching. The bitches at this time require 


\section{74 Cross Country with Horse and Hound}

special care and attention. They are separated from the pack and put in special lying-in kennels, their diet changed somewhat with the view of diminishing fever and increasing the flow of milk.

When now the third revolving moon appears

With sharpen'd horns above the horizon's brink,

Without Lucina's aid, expect thy hopes

Are amply crown'd; short pangs produce to light

The smoking litter, crawling, helpless, blind;

Nature their guide, they seek the pouting teat.

The puppies are confined with their mothers in the kennels for a time, and later a wire netting gives them a small enclosure. In fact, they are treated very much like a brood of chickens. From four to six puppies is the average number in a litter. Their eyes open when they are about ten days old, and the small enclosure is eventually removed, giving the whelps the freedom of the lawn or paddock. It is a beautiful sight - forty or fifty fat, awkward puppies tumbling about on the green. This goes on for six or eight weeks, during which time they are taught to lap milk preparatory to being weaned. After weaning they live first on milk alone. Later they may find a bit of nicely cooked oatmeal in the bottom of the pan, to which presently is added a bit of cooked meat chopped fine. A little later still, meat is given to them raw. About this time, too, the huntsman goes out to call on farmers or others whom he thinks may take a puppy to walk. Before a puppy is fit to wean, he is carefully tattooed or marked about his ears, and branded on his side, and a care- 


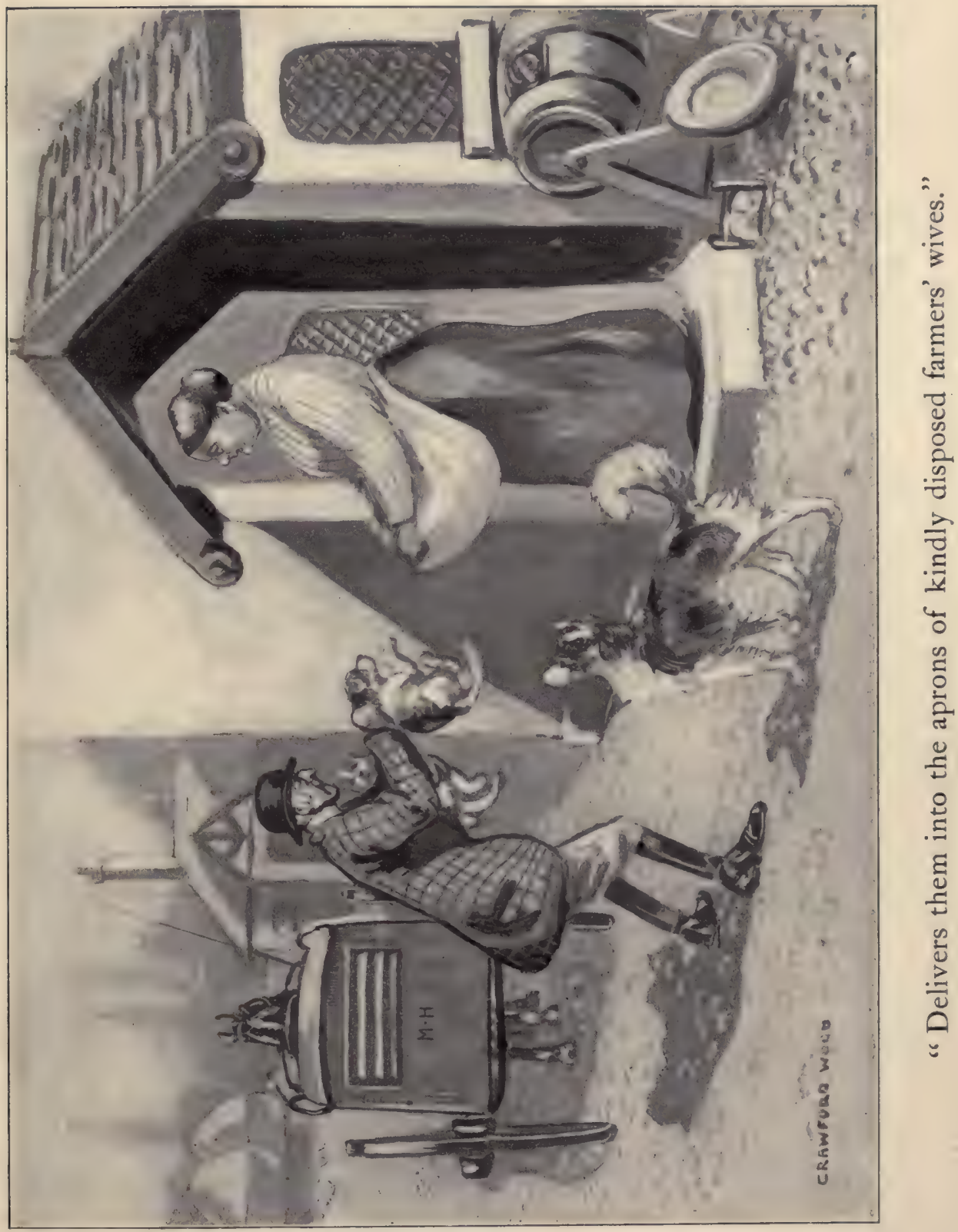





\section{Hound Breeding}

ful record is made of these brands, together with his colour, markings, and breeding. Soon after he is weaned some of the kennel servants, generally some superannuated member of the hunt, goes out with a load of puppies, to deliver them into the aprons of kindly disposed farmers' wives, who for the year to come adopt them into the circle of their domesticated household, to feed and chastise them and bring them up in the way they should go. A look at the puppy while at his walk shall be reserved for the following chapter. 

XVI

THE HOUND PUPPY AT WALK 
"s Then drink, puppy, drink; and let every puppy drink

That is old enough to lap and to swallow;

For he 'll grow into a hound;

So we 'll pass the bottle round,

And merrily we 'll whoop and we 'll holloa."

OLD HUNTING SONG

"And then, after dinner we found him asleep

In the bedroom up-stairs, where he lay in a heap

On the bed, which he covered with patches of dirt, -

His pillow we found was my latest new shirt."

RHYMES IN RED 


\section{XVI}

\section{THE HOUND PUPPY AT WALK}

AN IMPORTANT EVENT - MISCHIEVOUS PROPENSITIES - KENNEL DISCIPLINE - CUB-HUNTING

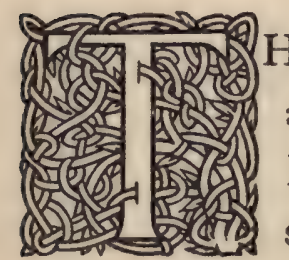

$\mathrm{HE}$ walk is a very important part of the life of a foxhound. He does so much better when he has the range of a whole farm instead simply of the kennels, where distemper and other epidemics are sure to prevail, that it is regularly a part of his education. Of course he is a mischievous brat, and makes no end of trouble. The farmer usually considers it better to take a pair of hounds than one alone, for when they are chewing away at each other they do less harm than one of them would do chewing the farmer's sealskin hat or Mrs. Farmer's fur muff.

The first year of a puppy's life, at walk under the indulgent care of Mrs. Farmer or her daughter, he surely looks back upon as one of the most enjoyable periods of his eventful career. He has nothing to do but eat, grow, and be merry. A litter of pigs to play with in the barn-yard, poultry to chase, cats to worry, perhaps a small boy for a boon companion - he has little left to wish for in life. Of course he makes the farmer swear and Madame Farmer de- 


\section{80 Cross Country with Horse and Hound}

clare she will never again allow another puppy on the place; to which her spouse answers: "Yes, you will; the huntsman will come here again next year, drink our cider, stay to dinner, compliment your coffee, and go away and send us another pair." Although the goodwife denies that she was caught by the huntsman's nice speeches, her husband strictly maintains his ground, and the question is dropped with, from her: "We shall see. This last puppy is the very worst one we ever had." But as she has been saying this for years, it is not considered worthy of a reply.

The farmer and his wife seldom renew the question, but when a neighbour calls, the first topic is the new puppy. The poor woman declares that "everybody's life on the farm is made miserable by the mischievous brute," and then goes on to tell the latest tricks the scamp has played - how he stole a leg of mutton as they were sitting down to dinner; and again, one day when the presiding elder was there to dinner, ate up the custard pudding the girl had set in the summer kitchen to cool. "Steal? They are the most rascally set of thieves out of prison. Why, that puppy kills more chickens and goslings every year than all the skunks and foxes in the county! The idea of growing up a foxhound to hunt foxes and preserve the poultry! Steal! Why, only the other day this puppy here came home lugging a neighbour's door-mat after him. And the butcher's wagon came along one day, and while the butcher was delivering a pound of sausages to the kitchen door the little whelp stole a whole ham out of his wagon. Served him right for gossiping with the hired girl. My land! but he was mad! My husband took him in and gave him a glass 
of cider, and when he came to the door again that puppy came running up with a leg of mutton. 'Look here,' says the butcher, 'is that dog trained to empty my wagon for you?","

The farmer, too, has grievances. He has spent an hour cleaning his overcoat, spongeing the mud-stains off, and hanging it over the chair to dry while he gets ready for church; but when he comes to put it on it is nowhere to be found. He hears a noise in the yard, and there is the puppy dragging it through the mud, shaking and snarling at it as if he were breaking a fox. At such times the farmer is apt to think puppies destroy more straw hats than a whole litter is worth, not to mention boots, shoes, slippers, rubbers, and lap-robes. If anything from an almanac to a bedspread is missing in the house, if anything from a currycomb to a horse-collar is missing from the barn, that puppy did it. It is impossible to keep the children clothed, for they will play with the puppies, whose teeth are as sharp as razors. "The puppies are an awful nuisance," the farmer ends; "but Mr. Master of Hounds is such a nice man! He sends me a brace of partridges or something every year for Christmas. We came near winning the cup he offered last year, too, for the best-walked puppy. The huntsman - and he is a nice man, too - said if we had not kept the puppy quite so well we should have had the cup. Puppy was a little mite too fat, he said."

But although the puppy makes the farmer swear, and sets everybody about the place by the ears, although the neighbours and the butcher threaten to kill him, he thrives under it all. He and the small boy who grow up together at 


\section{82 Cross Country with Horse and Hound}

least understand each other; and indeed all love him perhaps the better for the trouble he has given them. When, in the course of a year, say in April or May, the huntsman comes to take him up, everybody is sorry to see him go.

This departure from the farm is another very important and trying time in the life of a foxhound. When the hounds arrive at the kennels, the master comes out to look them over, and this day drafts all those who show crooked legs, weak joints, coarse heads, throaty necks, weak loins, or any other blemishes. Again pedigrees and memoranda are consulted. Some doubtful puppies may have another trial on account of pedigree or a particular fondness the master may have had for the fathers or mothers. All the lucky ones are kennelled by themselves, and the indolent, happygo-lucky days of puppyhood are at an end. The stern routine of the life of a foxhound has begun. A disconsolate set the puppies are at this time. Some refuse to eat until starvation finally drives them to it. Homesickness actually is so great in some that they pine and die of it. Some grow morose, and quarrel and fight and even kill each other. Such fights never fail to bring the huntsman to the door, and the offenders feel the sting of his double thong in a way they will be a long time forgetting. Altogether their treatment now is a very different thing from what Mrs. Farmer used to give them. The poor brutes wish, no doubt, they had been drafted with the rubbish. With harsh words and continual correction, confined day and night in a small room, obliged to sleep on hard wooden benches - no wonder if they feel like felons. Once a day some one comes to the door and drafts them into the 


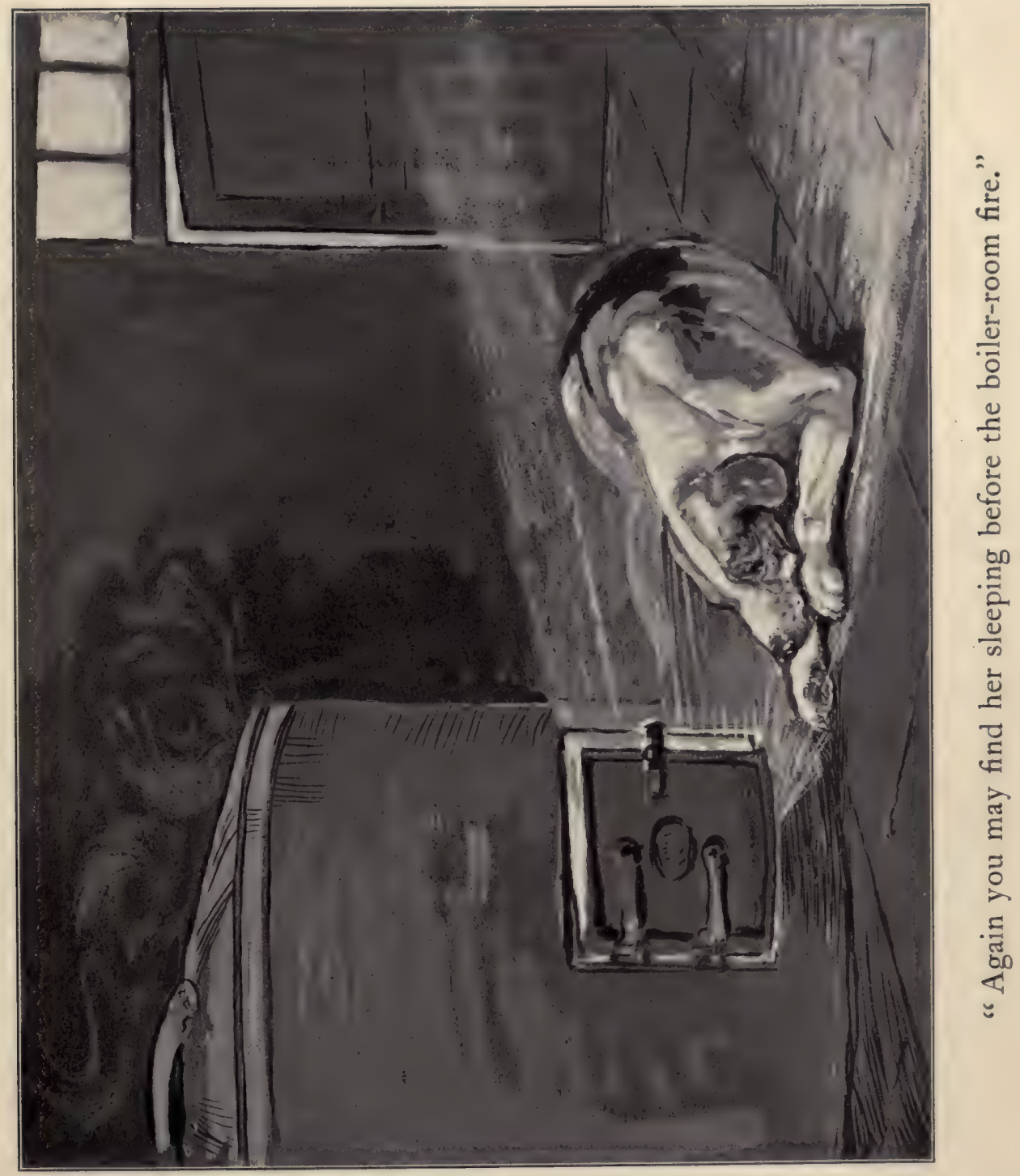





\section{The Hound Puppy at Walk}

feeding-room one at a time, calling each by name. Some one else is there to help a puppy remember what his or her name is. " Barmaid, Barmaid, Barmaid!" each time louder than before, cries the kennel-huntsman. The timid puppy starts, hesitates, runs back, gets a crack of the assistant's lash, and in she goes.

After a week or so each dog-puppy is coupled to a thoroughly trained bitch, and vice versa, and they go out for a walk, the huntsman and whippers-in going with them on foot. In the course of these promenades they are taken through fields in which sheep are grazing. Any tendency on a puppy's part to chase these brings correction of the severest nature. In olden days, if a new-entry hound persisted at all in going after a flock of running sheep he was coupled with a stout ram and dragged about the fields, or had his taste for sheep butted out of him by a ram who would stand his ground. After a few weeks of this exercise and discipline, the coupling is removed, and the huntsman and whips go out mounted. This daily exercise increases in distance until time for cub-hunting.

The life of a foxhound is generally from six to eight years, four or five seasons of work in the hunting-field usually finishing him. The master's heart is destined to be once more saddened when the time comes to dispose of his favourites because of infirmities or old age. Occasionally some favourite, Bluebells for instance, is given the freedom of the place, and hangs about the stables, spending her days basking in the sun or going with the master sometimes when he takes a walk; or again you may find her sleeping before the boiler-room fire, and by the notes that 


\section{84 Cross Country with Horse and Hound}

escape her musical tongue, the convulsive twitchings of her muscles, you know she is running a fox once more in her dreams. "Dear old Bluebells!" says the master, looking fondly down on her, closing the door softly, so as not to disturb her, when he goes out.

Cub-hunting is a particularly interesting period in the life of a foxhound. Many a promising puppy has finished his career with one or two trials. He may be a magnificent hound in every way, but unable to control his tongue, or run mute, or skirt. The master is particularly anxious during these days as to how his new entry will turn out. Cub-hunting itself is most interesting to all lovers of houndwork. Its drawback is that, owing to the dry, hot weather in September, scent evaporates or disappears so early in the day that six in the morning is as late as it can be expected to be followed. This means being called at half-past four. To a real sporting man the reward for such early rising should be quite sufficient, although I confess to a very limited experience.

By the first of September the youngsters have become quite proficient in road manners, and keep well clustered, besides showing great improvement in muscle. Plenty of road-walking has made their feet tough, but as yet they have never been blooded to the game they are to hunt. They have much to learn these cub-hunting days. The inexperienced puppy drops his head to the scent of a rabbit, a squirrel, a skunk, or a coon, and away he goes, full of fire and drive. But the huntsman knows it is not a fox, for the old hounds have hunted the ground over and said nothing about it; and Puppy is rebuked. Next a rabbit 
jumps up in front of him, and he takes after it like a shot. But the whipper-in takes after him, and "Ware rabbit! Ware rabbit!" he shouts, the thong of his hunting-crop sinking into the puppy's very flesh. Puppy, humiliated, sneaks back to join his fellows, with a look of reproach at the huntsman. He was trying so hard to do his best! The instinct for hunting has been bred in him for the last two hundred years, and now when he is brought into the woods he is flogged unmercifully. He sulks along while the cut smarts, but presently a reliable hound hits off the line.

“ Hark to Pedro! Hark to Pedro! On, Barman! On, my beauty!"

Thus addressed by the cheery cry of the huntsman, Puppy's spirit revives. He joins the others, gets a whiff of the fox's line, and away goes his tongue in a joyous shout as he drives at it with might and main.

Soon the sagacious brute, his curling tail

Flourish'd in air, low-bending plies around

His busy nose, the steaming vapour snuffs

Inquisitive, nor leaves one turf untried,

Till, conscious of the recent stains, his heart

Beats quick; his snuffling nose, his active tail,

Attest his joy; then with deep-opening mouth,

That makes the welkin tremble, he proclaims

Th' audacious felon; foot by foot he marks

His winding way, while all the list'ning crowd Applaud his reas'nings.

On the outside another young entry catches the stronger line of a rabbit, and goes after it with clamourous tongue, 


\section{86 Cross Country with Horse and Hound}

taking three or four youngsters with him. But he has not gone a rod before crack! crack! goes the whipper-in's crop, like the report of a gun, straight at the false leader's side. "Ware rabbit, Puppy! Ware rabbit!" A few strides of the spur-pricked mount places the whipper-in in position to head the puppies off, and the tooting horn of the huntsman calls them back to the line of the hunted fox.

So the day is spent breaking in the new entry, permitting them to kill two or three cubs, to get the young hounds well blooded. But this is only half the object of cubhunting. The young foxes need educating as well as the hounds. The first covert drawn is one where there is sure to be a litter, and one object, so far as the young foxes are concerned, is to bustle them about, so that when the regular season opens and they hear hounds coming, they will break covert quickly. No sportsman likes to hear of hounds " chopping" a fox in covert. They desire to give him plenty of law, a very generous start, and then catch him if they can. It is not sport to take game at a disadvantage. To the genuine sportsman it is something shocking to see a man hunting rabbits with a ferret. The ferret is sent into the burrow, out bolts the rabbit, and the gunner with a shotgun at the mouth of the hole blows the top of bunny's head off. Or he gets some blank cartridges and a hundred feet of fuse, fastens the fuse to a cartridge, and with a piece of wire rams the cartridge in a burrow. Bang! goes the cartridge, and out bolts the rabbit or fox to certain death. Shame on the men who call this sport! They are not sportsmen, but butchers. Sportsmen of this calibre ought to go home, rope an ox, draw him on the barn floor, and 


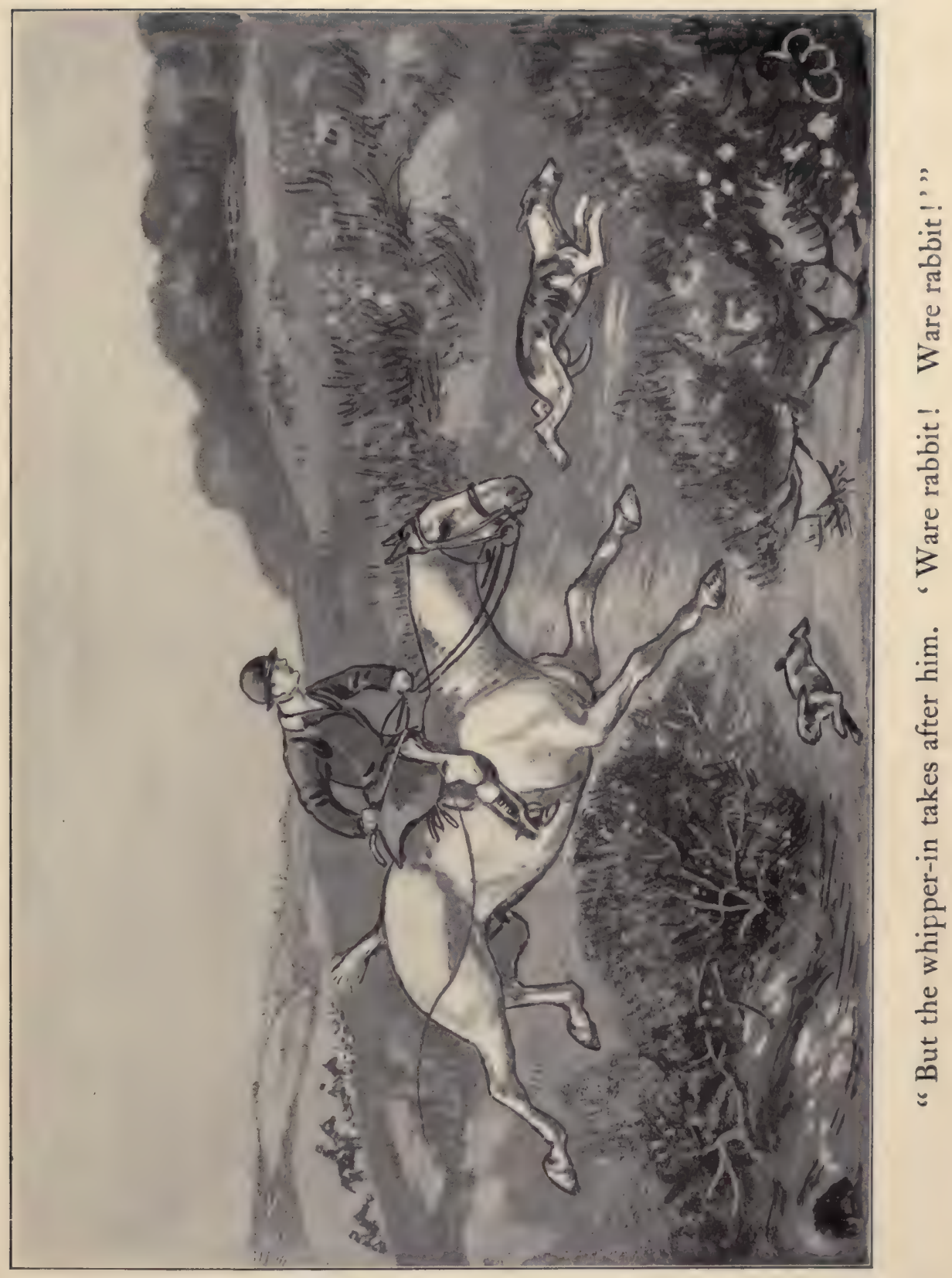





\section{The Hound Puppy at Walk}

knock him on the head with an axe. It would be the same kind of thing. "Was the bird flying from you, or across or toward you, when you hit it?" asks the father of his son who comes running to him with his first partridge. "He was sitting on the ground," replies the delighted boy. "Sitting on the ground!" roars his father. "Sitting on the ground! Never let me hear of your doing such an unsportsmanlike thing again. Always give the bird a chance, my boy. If he does n't get up, frighten him up. Then, if you are clever enough to drop him, there is some credit in the shot." Such should be one of any boy's first lessons. But a great deal of this butcher business goes on in America, for one reason or another. A man is not satisfied to catch fish by the skilful throwing of a fly, but must buy a net or explode a charge of dynamite in the bottom of the pool, and pick up the murdered fish as they float to the surface. And they call this sport!

But ware fish, author, ware fish! and get on with your fox. As I was saying, no fox-hunter likes mobbing a fox in covert, and so it is necessary to give the youngsters a lesson in breaking away. They start one fox out, give him a good scare with hounds after him, and when he is well out of covert they call off the hounds to bustle out some more.

No one has better described cub-hunting than Somerville in "The Chase," that epic of the hunt from which we have already borrowed more than once to enrich our own pictures:

Easy the lessons of the youthful train

When instinct prompts and when example guides.

If the too forward younker, at the head, 


\section{88 Cross Country with Horse and Hound}

Press boldly on, in wanton, sportive mood, Correct his haste, and let him feel, abash'd, The ruling whip. But if he stoop behind, In wary modest guise, to his own nose Confiding sure, give him full scope to work His winding way, and with thy voice applaud His patience and his care; soon shalt thou view The hopeful pupil leader of his tribe, While all the listening pack attend his call. 
XVII

THE FOX 
"The wily fox,

Safe in the increasing number of his foes,

Kens well the great advantage; shrinks behind, And slily creeps through the same beaten track, And hunts them step by step; then views, escaped, With inward ecstasy, the panting throng In their own footsteps puzzled, foiled, and lost." SOMERVILLE 


\section{XVII}

\section{THE FOX}

THE FOX COMPARED WITH OTHER GAME - HUNTING THE WILD RED DEER - A PATHETIC END - RENARD'S CRAFTY NATURE

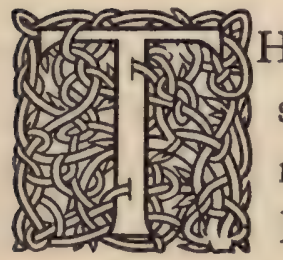

$\mathrm{HE}$ drag is but a mimicry of hunting, the crated stag is but little better, the bag-fox an abomination savouring too much of the butcher. Hare and otter-hunting are good, clean sport. The hunting of the wild red deer in Devon and of the wild stag and the wild boar in France are thoroughly honourable and sportsmanlike. The woodcraft of the harbourer, the rare skill of the huntsman in singling out a warrantable stag or hind, are a display of natural wit and cunning beautiful to see. It is a glorious thing, riding to staghounds, to note the wonderful instinct of the huntsman in lifting them smartly on to the line when they are at fault. But for every-day hunting there is nothing that quite comes up to the chase of the wild fox.

There is never, in the chase after Renard, the feeling that you are pursuing to its death a harmless and innocent creature. The fox is a vagabond. If he was not at work stealing your chickens last night, it was because he was stealing your neighbour's, or came across a rabbit that diverted 


\section{Gross Country with Horse and Hound}

him on the way to your coop. There is something of retribution in his being killed. On the other hand, I shall never recall without a shudder the death of the first hind I saw taken by the Devon and Somerset staghounds.

She had given us a glorious run of fourteen or fifteen miles to Bristol Channel, to which waters her instinct had led her as the best way of escape from her pursuers. When we arrived on the coast, at the point where the hind had jumped over a steep precipice and taken to the sea, there was a heavy fog resting on the waters, and the chase seemed ended.

Presently, however, the fog lifted, and there, standing on a rock a quarter of a mile or more to sea, was the hind, the most beautiful picture I ever beheld. Over her hung a canopy of mist; the surf of an incoming tide was breaking into the whitest foam at her feet. Steadily the tide crept up on the rock where she stood, every succeeding breaker increasing the depth of water about her. There she stood like a stranded mariner, awaiting the death that must ultimately overtake her. She began to look longingly toward the shore and the frowning peaks of the Quantock Hills, her home, to which she was never to return. For a time her attention was called to the passing of a ship not a quarter of a mile from where she stood, curiosity for a moment absorbing her as she watched it with forgetful interest. What a picture! More than an hour we waited and watched, during which time the hounds were taken out of sight. It was hoped she would come to shore and make for the hills; but still she lingered, with the incoming tide rising all about her, and huntsmen 
waiting for her on the banks. Now the waves reached her body, and she looked startled and seemed to read her doom in every succeeding billow. She made a move irresolutely toward the shore, halted, and moved again. Carefully she felt her way down the slippery rock till finally the sea closed over her back and she could be descried swimming for shore. Reaching the beach, she walked out again a bit to free herself from the breakers, and rested there for ten or fifteen minutes longer. The huntsmen meanwhile, with five or six couples of the most trusty hounds, went down to the water some distance above her, with a view to getting between her and the sea. She saw them coming, but the cold March wind had evidently chilled her to the marrow; she moved with stiffened gait along the shore until she came to a great boulder, behind which she stole cautiously, and lay down in a pool of water left by the last tide in a hollow of the rocks. A moment later the hounds hit off her trail, and in another instant the lot of them were upon her.

To me, unaccustomed as I was, it gave a sickening feeling, despite its novelty and interest. I can best express myself in the characteristic language of an American girl after her first ride down the great toboggan slide at Montreal. "'I would n't have missed it for a thousand dollars," she said, " but I would n't go through it again for two thousand." Perhaps there is nothing like getting used to a thing; perhaps if I hunted year after year with these famous hounds I should become hardened to such spectacles; perhaps the wild red deer, killed by these hounds to the number of one hundred every season, become at last, 


\section{94 Cross Country with Horse and Hound}

like the old lady's eels, accustomed to being skinned. But I have had several days with these hounds since that first one, and somehow I doubt it.

Let us hark back to our fox, that cunning, evasive thief of the night. Any one can see him broken with little feeling of compassion, knowing that the untimely death of Mrs. Farmer's goslings has been avenged. As he hunts the hare and the rabbit, he has no reason to complain if he is hunted too. What is more, he is not a good sportsman. He pounces upon his prey by stealth, while for him hounds are kept back to give him a good start, and the music of their cries, the shouts of the huntsmen, the clatter of the galloping steeds, all leave him less and less excuse to say that he has not been fairly dealt with. He usually gets away on an even footing, and has about even chances of saving his brush for another day. There are, indeed, always a few old ringers in every hunt country that seem to welcome the coming of the clamourous pack as if it were a game of hide-and-seek or blindman's-buff. But most of them are sly. When you see one sneaking along a fence after playing a clever trick on the hounds, you have an eager desire to run the rascal down. No, there is an indescribable something about the pursuit of a fox that fires the blood of a hunting man as does that of no other game. Shooting partridge, quail, or pheasants over a couple of well-trained pointers is very keen sport, I allow. Wild-turkey shooting in Michigan, going after wild ducks and geese in New Brunswick, stalking deer in Maine or caribou and moose in Nova Scotia, are most thrilling. But none of these animals make you want to get at them so badly, or rather I might 


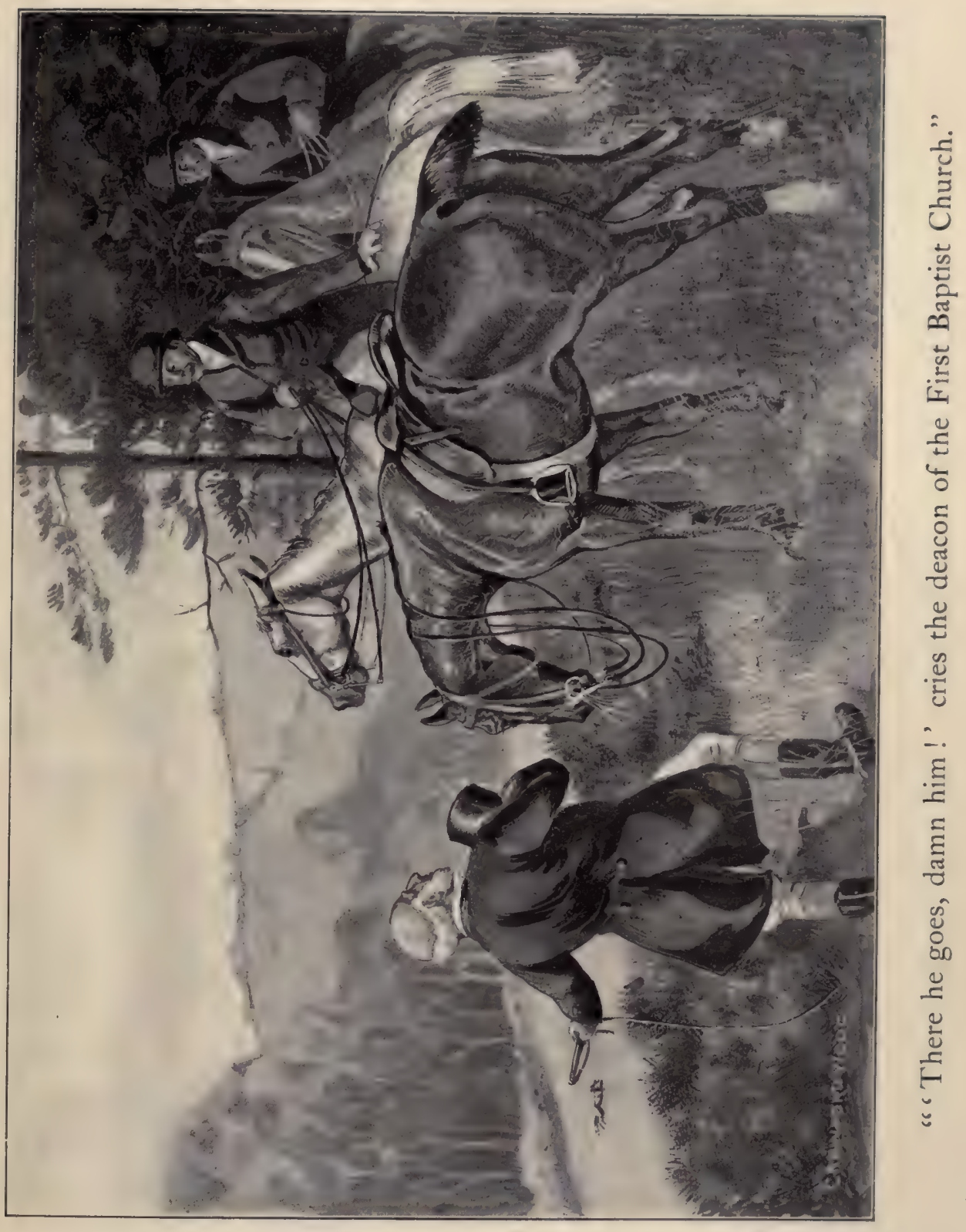



better say so madly, as the fox. Every hunting man feels this, but words to express the feeling fully are yet to be invented. Some men who are as steady as a church at bird or big game shooting fairly lose themselves at the sight of a travelling fox. There is something about his stealthy way of going, as if he were a thief, something about his whole carriage, that proclaims the rogue and makes men shout themselves hoarse and ache to throw their hunting-crops or hats at him. They will ride their best hunter nearly to death to keep in sight of him. All this, however, is lost with a bag-fox; and, as some one has pointed out, none of it at all would arise at the sight of a fox chained to a stake in some one's yard. But directly hounds give tongue in a genuine hunt, your spirits are up and your interest grows apace in the game. For every card the rascal plays you know, so to speak, he has still an ace or a king up his sleeve. A glimpse is had of the sly little devil as he moves along in a furrow, casting his eyes behind him with the cold, calculating glance of a moneylender. "There he goes, damn him!" cries the deacon of the First Baptist Church, who was never known to swear before,- and did not know he did then,- as he puts spurs to his horse and races after as if he were running down a desperado.

It is undoubtedly true that the greatest zeal for foxhunting, as in other kinds of hunting, comes from a knowledge of the animal hunted, and is increased by a study of his ways. It always seems to me that men who hunt to ride miss this point and the spirit of the chase altogether. Their pleasure consists in outriding the field, 


\section{96 Cross Country with Horse and Hound}

and if they fail in this they go home disappointed. Not so the hunting man. His heart is in the game. Those who hunt to ride may as well follow a drag or ride a steeplechase. The hunting man has all this pleasure, and the enjoyment of the hunting as well. Pardon my recurring so often to this point. I am only anxious to give the novice a start right, which is not likely to be the case unless he is quite familiar with the game. It will not be amiss, therefore, to devote a little more space in the next chapter to "The Fox and his Ways." 


\section{XVIII}

\section{THE FOX AND HIS WAYS}


s The farmer, who beholds his mortal foe

Stretch'd at his feet, applauds the glorious deed, And, grateful, calls us to a short repast:

In the full glass the liquid amber smiles,

Our native product; and his good old mate

With choicest viands heaps the liberal board."

SOMERVILLE 


\section{XVIII \\ THE FOX AND HIS WAYS}

BREEDING SEASON - FIRST LESSONS IN CRAFT CUNNING - WHAT THE EARTH-STOPPER SAYS - WHAT THE FARMER

AND HIS WIFE SAY

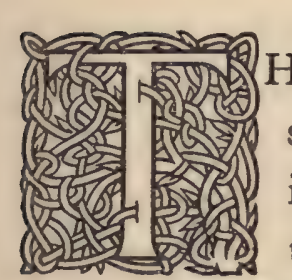

HE fox's mating season in America varies somewhat according to latitude. January is in most regions the month for courting. In these days the dog-foxes travel great distances with a view to finding a vixen in every way worthy to become the mother of the most crafty foxes that ever lived. The general belle and favourite, no doubt, is she who has the best record for fooling the hounds. The most successful chicken-thief comes next, perhaps, in popularity.

Simpson, the earth-stopper, says the cry of the vixen at this season is something to make even " an old stager like me creep all over, so weird and human-like is the sound." It is sure to remind Simpson, as does everything else you may mention, of the battle of Gettysburg.

The vixen is with cub only nine weeks, and has but one litter a year. About the first of April there is many a happy fox-mother. April Fools' Day is the appropriate day when cubs are apt to come into the world, which 
200 Cross Country with Horse and Hound

perhaps accounts for the fooling proclivities of the Renard family.

If hounds break cover with a vixen during these domestic affairs of the fox family after, say, the middle of January, they are called off, and madame from that time on is shown every consideration. She gets a bit of an ousting now and then until her sex is discovered, and this is no doubt very good for the future generation, for their mothers may thus be able to transmit a bit of instinctive knowledge about foxhounds that the foxes of an earlier generation had to learn by hard experience. There has been considerable discussion among hunting men as to whether foxes are keener game now than they were forty or fifty years ago. A comparison of the number killed and of the length of runs would indicate that they are not. We must consider, however, that foxhounds have steadily improved, and horses as well, so that it need not follow from statistics that foxes have lost their cunning. On the contrary, they, as well as the hounds, are likely to have grown in stoutness and stamina.

Now come the planning and arrangement of the new home. In the course of time a suitable lying-in room is arranged on the ground floor, which apartment madame arranges to suit herself. It is said that a vixen gives birth to her cubs outside of the earth, and then moves in, bag and baggage. Her lord and master basks in the sun on a southern exposure of the covert by day, but at night goes forth to replenish the larder, leaving madame to devote her time to her household duties and prepare for the coming event. 
Hounds are said not to follow a vixen heavy with cub. Perhaps it is a certain sportsmanlike instinct among wild animals that prevents their killing their prey under such circumstances. One explanation is that the scent left by expectant mothers is too weak to be followed, or changes so as to be no longer recognisable. In either case a wise provision of nature seems to interfere in their behalf. I believe I have seen it somewhere recorded that hounds, if they come upon a vixen heavy with cub, will, of their own free will, not break her. I have either been told or have read of instances where hounds, having overtaken and killed their fox, but finding it a vixen heavy with cub, have left it alone, and have been found lying about the corpse with no apparent eagerness to taste her blood. I quote also the following from Thomas Smith's charming book "The Life of a Fox as Told by a Fox": "I heard the hounds running a fox close to me, which they very soon lost, as they could not or would not hunt it. I thought this very strange, as by the use of my nose I knew it was a good scenting day; but it turned out that the fox was a vixen who had just laid up her cubs, the effect of which generally is to make the scent so different that hounds, old ones particularly, appear to know it as if by instinct and will not hunt it."

One fine day madame sends her husband to a human neighbour's where, she tells him, he will find a nice fat turkey that Mrs. Farmer has neglected to lock up for the night. This is simply a joke, and the unsuspicious husband, when he returns, finds a surprise for him. Four, six, or even eight cubs have come to "bless the union" of himself and 


\section{Cross Country with Horse and Hound}

his spouse, as the old-time biographers would say. They have been left in the earth by a passing angel, madame explains. Her husband forgets the scolding he had prepared for her for sending him on a fool's errand, and goes off and kills a farmer's lamb to celebrate the event. The good Lord keeps the cubbies' eyes darkened for ten days, or they might wander away from the fireside and perish, and madame has stored up a good supply of fat on her own body, from whence her babies may draw should the larder run low. The same over-ruling Providence, as Mr. Thomas Smith's fox points out, brings the family into the world at a season of the year when their favourite food, young rabbits and beetles, is most abundant. Not only is no vixen ever hunted in these days, but some huntsmen maintain that no dog-fox should be hunted after the first of April, as madame needs him to do odd chores about the house and assist in keeping the supply of food sufficient for the increasing wants of the family.

It is generally believed that the dog-fox may be distinguished from the vixen by the white tip on the end of his brush. The fox above quoted says this is not an infallible sign, however. "I, a dog-fox," he says, "and one of my brothers, and also one of my sisters, had it [the white tip], whilst the other sister and the other brother were altogether without it, not having a single white hair. $\mathrm{My}$ brother has been known to profit by the exception when on being viewed in the spring of the year the hounds have been stopped with the remark, "It is a vixen; there is no white in her brush.' I have since observed that old male foxes are of a much lighter colour on the back than are 
the old females, which are commonly of a dark reddish brown."

The white tip on a vixen, I believe, is the exception to the rule, but, however that may be, the ladies are easily distinguished - if you can get near enough to note - by their size and especially by their more sharply pointed noses. The question of colour, especially of shade, is a very uncertain one; it not only varies in the same litter, but, to some extent, with the change of coat and season.

Soon after the cubs' eyes open, they are brought to the mouth of the earth and given their first lessons in diving back into this harbour of safety at the slightest noise. Later, if the earth is in any way disturbed, they are moved usually some distance away, and after that are kennelled out of doors. They are carried by the mother just as a domestic cat moves her kittens, one at a time, lifted by the nape of the neck. In this way a vixen will sometimes move a whole family several miles during a single night. Beetles and mice and later a young rabbit are brought in, which mother proceeds to break in truly workmanlike manner, dividing quite fairly. Simpson, the earth-stopper, tells me madame is very particular in these divisions of her spoil, never taking a mouthful of it herself, but devoting all her time and energy to teaching etiquette to her family. Such a meal is generally consumed at some little distance from the home. The cubs, who have been waiting and playing about the earth until their mother's return, at a call from her rush away to meet her, and are then, perhaps, taken still farther away to some secluded spot that she knows of, before the fare is served. On no account must a 


\section{Cross Country with Horse and Hound}

bit of fur or feather be found about the earth. Gypsies are not more careful of observing this rule than a vixenfox. After a meal of this sort the brood go back to the mouth of the earth, and top off their dinner with a dessert from the maternal store, madame looking proudly on while they frolic and play about her, darting into the earth now and again at some real or imaginary noise.

The amount of assistance madame gets from her husband these days is a matter much disputed. Some earthstoppers maintain that he gives none whatever; others, like Simpson, that she is much assisted by the "old man"; and if vixen is killed, Simpson declares, he takes up her household duties as well as he can.

Cannon, an earth-stopper to the Quorn Hunt, with whom I once had a night tramp, says foxes are not so wicked as they are painted. "It is," he says, "only when the master of a family has been killed, and madame is unfortunate in hunting rabbits, and becomes desperate and reckless of her own safety, that she resorts to stealing poultry and young lambs." This view seems rather extreme. But possibly the diversity of opinion among earth-stoppers and hunting men is owing to the fact that there are foxes and foxes. One thing is certain: sometimes they will take away a single lamb or hen, and again they will kill twenty hens in a single night, hardly tasting their flesh. This, the earth-stopper says, is the work of a dog-fox who is out for a lark and not to satisfy hunger. Simpson declares that a fox never steals a chicken or a lamb from the farmer on whose farm the earth is laid, but will go a long distance from home to the neighbourhood of some other fox, who 
he is quite willing should be trapped or shot for the offence. Some things one hears from earth-stoppers are quite suggestive of fairy-tales, but the cunning of a fox is so well understood that it is quite easy to believe almost anything.

That the fox tracks rabbits by scent, as he himself is tracked by the hounds, is shown by following both their tracks over wet and muddy fallows or on snow. It is from the rabbit, perhaps, that the fox learns many a trick, for a rabbit can give even a fox points in dodging. If you wish to see the prettiest exhibition of hound work in the world, you should watch a pack of harriers or beagles following the line of puss. The proverbial Chinese puzzle is easy in comparison.

Of course no farmer with any self-respect would shoot or trap a fox in a hunting country; on the contrary, farmers are very proud of having a litter of cubs laid upon their farms, and do all they can to protect them and see that they are not disturbed. Every earth in a hunting district is known to the earth-stopper, and if a litter of foxes known to have been laid on a certain farm is not found there at cub-hunting time, it is a humiliating state of things to the farmer who values the good opinion of the county. When such things do happen in England, the owner of the covert not at all infrequently sends to London and buys a fox or two to turn loose in his covert just before they are to be drawn. Nothing could cause a farmer more chagrin than the finding of a trap on his farm. Altogether the fox is the most favoured and pampered wild animal on the farm. 


\section{Cross Country with Horse and Hound}

Once when I was visiting my friend Mr. R. Kirkham in Lincolnshire, he took me one day back on his farm to see a litter of cubs that he was very proud of. He was afraid, however, the vixen was not a good milker, for the cubs did not seem to be doing as well as he thought they should. Perhaps, he added, Mrs. Fox may have been left a widow; so we took with us a basin of chicken bones and scraps of meat, and left them at the poor vixen's door.

"I don't want to do this sort of thing too much," he said apologetically, probably because the pan was not full. "It won't do to encourage idleness, you know. Foxes, to be kept in good health, must have work. Besides, I want them to be very fit when the hunting season opens, so as to give us the run of the season."

Such are the sentiments of an English tenant-farmer, who seldom rides to hounds himself but who is the right sort nevertheless. Mr. Kirkham gives a most interesting account of the habits of foxes; he has evidently spent considerable time in looking after the widows.

"I often come up here to see how they are getting on," he says, "and sometimes I am able to steal up and get a sight of them playing about the earth like a lot of kittens. One will pretend to be dead. He lies stretched out, apparently cold and stiff as a corpse, and with his eyes closed, though I think he keeps them a wee crack open. The breeze plays with his hair, and altogether there never was an act done truer to life, or, I should say, death. Seeing this, another cub approaches cautiously, when up springs the dead one, and the pair clinch and roll over in a goodnatured wrestling match. This is only the rehearsal of the 


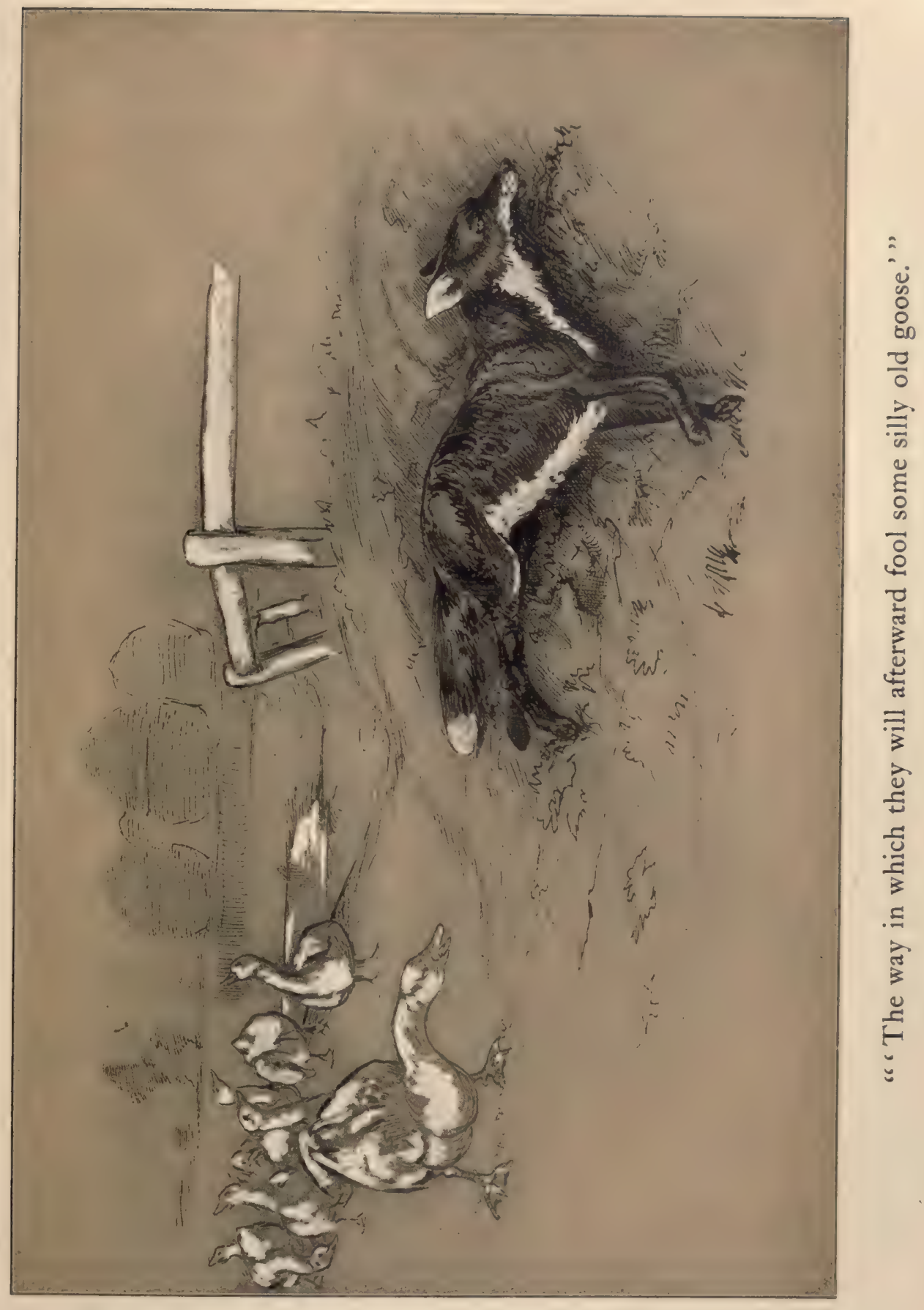





\section{The Fox and his Ways}

way in which they will afterward fool some silly old goose whose curiosity gets the better of her judgment. Then they will chase each other. The leader, springing to one side, lies flat until the other, unprepared for the dodge, rushes past, and the pursued rushes back to the earth. This is their trump trick, and the one that more than any other saves their lives when pressed by hounds. As the cubs get a little older, Madame Fox takes one or two at a time with her on a hunting expedition. She seems to think her years of practical experience are necessary to the young things, and doubtless they are of great value."

In such ways the cubs grow more and more wily and schooled in all the tricks and craft in which as a family no other quadruped is their equal. It would require pages to record all their cunning in pursuit of their game. Later we shall attempt to show other examples of their cleverness in the tricks they play upon the hounds and the stratagem of the huntsmen in circumventing them. Like chess, hunting the fox is a deep game, and it requires a clear head and years of experience in woodcraft to play it well.

Discoursing of the fox and his ways, Mr. Kirkham and I returned to the house late to dinner. Upon my host's apologising and madame's learning what had detained us, I was amused by the good-natured sparring match that sprang up between them on the same old subject.

"Well," began Mrs. Kirkham, "if I wasted as much time as you do looking after that vixen and her cubs, I should never expect to get any dinner. Here 's dinner now, nearly spoiled."

Her husband turned to me with a sly look in his eyes. 
208 Cross Country with Horse and Hound

"But if you will raise foxhound puppies," he replied, "I must provide them with something to do when they are grown. You know it costs more to raise a couple of foxhound puppies than half a dozen Lincoln sheep, and if you take into account what they destroy I might say a dozen. Now, foxes," declared my host, "are not nearly so expensive a luxury."

"Are n't they, though? As I get the proceeds of the poultry, perhaps I ought to know. Don't you mind how they killed my best prize-winning silver dorking cock last year, that I refused five pounds for at the Royal Show?" “'That was n't the fox's fault. What can you expect when you don't properly lock up your cocks for the night? Besides, I don't believe a fox killed your bird at all. It must have been a skunk or a weasel did it. My feeding the cubs occasionally is only a safeguard against their stealing your chickens."

"Well," retorted madame, whom her husband in courtesy, like the sportsman he is, permitted to have the last word, " if you rear foxes on the farm, I must grow the hounds to kill them."

This brought the argument to a standstill, with honours easy and neither party to the dispute perhaps essentially dissatisfied. 
XIX

SCENT 
"To ev'ry shrub the warm effluvia cling,

Hang on the grass, impregnate earth and skies.

With nostrils op'ning wide, o'er hill, o'er dale,

The vig'rous hounds pursue, with ev'ry breath

Inhale the grateful steam; quick pleasures sting

Their tingling nerves, while they their thanks repay,

And in triumphant melody confess

The titillating joy." 


\section{XIX}

SCENT

SOME THEORIES COMPARED - FONDNESS OF HOUNDS FOR THE TRAIL - HOUND MUSIC AND A NOVICE

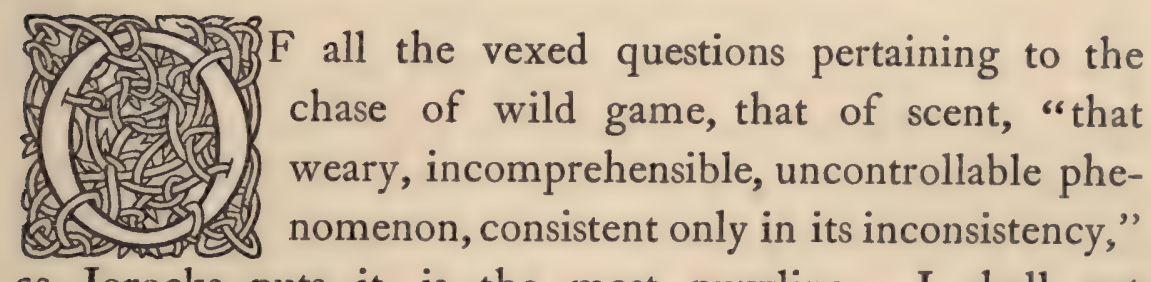
as Jorocks puts it, is the most puzzling. I shall not attempt to enter into a full discussion of this most interesting problem, but content myself with stating a few wellestablished facts, and leave the reader to work out the riddle as best he can. It will be found a good subject to occupy his mind during a long ride home. But I give him fair warning that the hypothesis he sets up to-day to his entire satisfaction is likely to fall like a card house at the very next run or before the attack of some one who is further along in the study.

I believe, however, all theorists sooner or later come to acknowledge that certain conditions of the atmosphere seem to favour the lasting qualities of the scent, though in some way that makes barometers or thermometers unsatisfactory guides. The breaking of a frost, the evaporation 


\section{I 2 Cross Country with Horse and Hound}

of the dew, is thought to take with it the line of the hunted game. A porous or sandy soil is believed to absorb it. The scent itself is thought by some theorists to be left by the feet, by others to come principally from the body, while still another school says it comes from both.

All agree, also, I believe, that a sleeping fox gives little or no scent, that if he keeps still in covert, as he sometimes does, hounds can and do run over and all about him without detecting his presence. Again, if he has gone in a leisurely way out of covert just before hounds arrive, it is with difficulty that they are able to own the line, even on a good scenting day. It is during this first part of nearly every run that a clever huntsman urges on his pack as fast as ever he can and still keep their noses down; that is to say, as fast as he can just short of lifting them forward. His idea is to get them on good terms with their fox and that particular one as quickly as possible.

That under favourable conditions scent improves or grows stronger as the chase of the heated fox progresses, and dies down or weakens when the fox becomes exhausted, is also clear. Many a sinking fox but a few yards ahead of the hounds saves his brush because hounds are no longer able to follow the line. It has, indeed, been noticed that some of the older hounds begin driving to the front the moment they detect this weakening of the scent. Experience has taught them that the end is near, while younger hounds lose interest because the sensation is now less stimulating to their olfactory nerves. This is so established that when old experienced hounds from going in the middle or rear of the pack make a dive to the front, it is taken 
as a signal that the game is almost up, and knowing riders put on more steam to be the first in at the death.

Particular foxes have particular odours of their own, stronger in some than in others, probably owing to their physical condition or the state of their health. If this were not so, hounds would be always changing foxes. The more experienced hounds have learned that it is best to stick to the fox they started with, whether his scent be strong or weak, and the huntsman uses the greatest care to see that the pack does not change. The younger members have this to learn. When they are seen to drive ahead while the older hounds check, the huntsman knows for a certainty almost that they have changed foxes. The whipper-in rushes to the heads of the youngsters to turn them back, while the elders stick to the original fox. This they are able to do even if the latter's line crosses a dozen fresh lines, some of them much stronger, perhaps, than the one first followed. That it is desirable to keep to the one fox is obvious.

That scent is good or bad largely owing to the condition of the atmosphere is a point on which nearly every one agrees. At the same time, it seems due not to any condition registered by barometer or thermometer, but to some element pervading all ether, else a passing current of air would dispel it. One often sees hounds racing to a line that has half a gale of wind blowing across it, or, on a still day when hardly a leaf is stirring, unable to follow when the fox is not ten rods away. That the coarser particles which make the scent may be blown away on the air, no one can doubt; there must nevertheless be some property 


\section{I 4 Cross Country with Horse and Hound}

of them which remains. Of course a dry, hot day, a parched pasture, a hot sun, is bad for scent. In a way, the action of scent is not unlike that of smoke or steam. On certain days a locomotive leaves a trail of steam or smoke that ascends quickly to the upper air; again, one that descends as quickly to the earth, or hangs evenly in mid-air just above its point of issue. On some days steam vanishes from view directly upon leaving the mouth of the stack; again, it leaves a white path a quarter of a mile long in the wake of the train. All these different aspects are doubtless owing to some atmospheric influence, and just so it seems to be with the scent of a fox - sometimes rising quickly, as it does, sometimes clinging to the grass and bushes for yards on either side of the line, or hanging slightly above the earth so that the hounds instead of stooping to it race away with heads up and sterns down, running, as the saying is, with "scent breast-high." Sometimes it is spread so wide to right or left of a line that every hound in the pack, although running rods to either side of the line, can "feel" it.

That scent does not come from pads alone is evident from the ability of hounds to follow it a long distance in watersoaked ground where the fox has had to wade, or across a wide stream which the fox has had to swim, the water through which he swam having moved downward with the current. It happens that scent will be good in one field and bad in the next, one being sheltered by a piece of wood, the other not. Conditions of the atmosphere of one field may not exist in the next. That bare ground and fallow land are not usually so good as grass and stubble is accounted 
for by the fact that the particles of effluvia left behind by the fox, if they settle, have not so much to cling to. The "working," as the farmers call it, of a newly ploughed field may cause chemical action there that absorbs or dispels scent, and yet again such land sometimes carries the scent beautifully, even across a dusty highway. Others believe a sandy soil absorbs scent, but I have little faith in this theory. The scent more likely goes the other way, on heat waves caused by rapid radiation, for if absorbed by sandy or porous soil the particles would adhere to the soil, and make the line, if anything, plainer than it is on a hard clay, in which as a matter of fact scent is generally better. Clay ground is believed to hold a scent longer than sand or loam, and probably does, because evaporation is less than on sand. But enough of this: I meant only to advance a few theories to set one thinking upon this ever-interesting topic.

Still another peculiarity of scent is the hounds' extraordinary fondness for it. Disagreeable as the odour is to man, hounds seem ever more keen to follow a fox's line than to break the fox himself. The huntsman has generally little trouble to secure a fox from the hounds after they have killed him; at least, hounds never seem so eager to make away with him as one would expect from the greediness with which they pursued his line. Judging from their actions in covert, the first nostrilful of the scent fairly intoxicates them. Their sterns lash, and each particular hair on their backs stands on end. They raise their heads and throw their tongues with a clamourous yell of delight that fairly sets them back on their haunches. If 


\section{I 6 Cross Country with Horse and Hound}

the line is faint they can hardly contain themselves, and whimper and cry like children with disappointment. Here indeed is one of the severest tests of a hound's truthfulness. Sometimes his imagination runs away with his judgment, and away goes his tongue. The other hounds leave their work and rush to the babbler's side, but fail to confirm him. The disgusted expression a hound shows at such a false alarm is something almost human. He comes on a run, cropping his head for a taste; but when the mistake is discovered, his whole countenance changes and he stalks away disgusted. The huntsman meanwhile has his eye on the babbler. Once or twice more of this sort of lying, and the deceiver's days are numbered.

The other hounds, fooled once or twice, pay no further attention to him, even if he speak the truth. But let one of the old hounds proclaim the news, and instantly every hound is at his side.

"That 's old Bluebells!" cries the major, as he and his knowing old horse Friar both eagerly listen for a whimper. "That 's old Bluebells! There is a fox on foot, that 's sure. I 'd take that old bitch's word for a million." And he charges on around the covert where his black-and$\tan$ beauties have set their fox on foot.

It is a beautiful and stirring sight to watch twenty-odd couple of well-bred, perfectly schooled foxhounds when drawing a covert. How they fling themselves here, rush there, now in a bunch with heads down and sterns waving wildly as if a tornado had struck them, now scattered, one running straight ahead for a rod, to stop suddenly and cast 


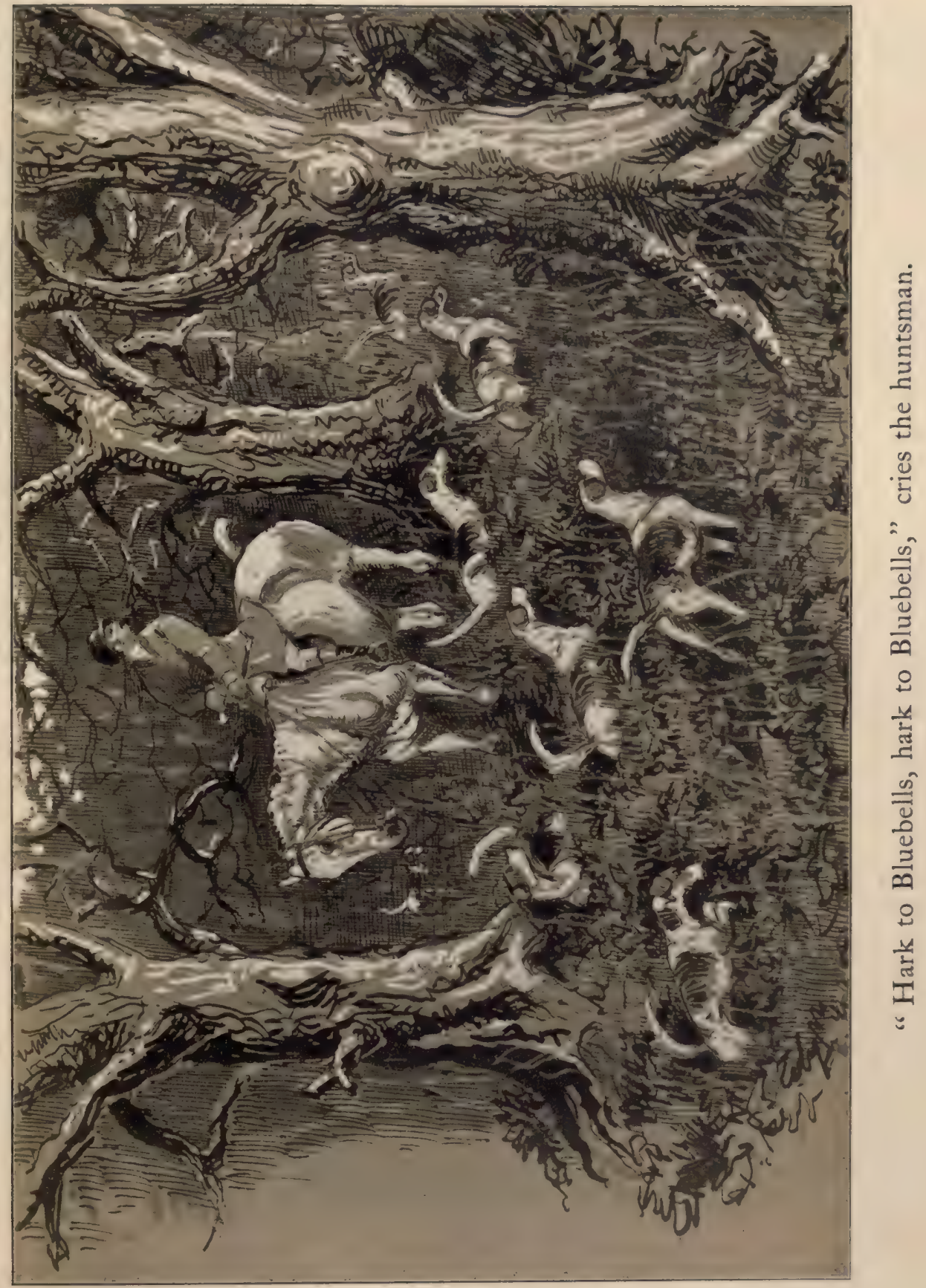



back! "Edawick, Edawick!" shouts the huntsman, or, to encourage them to draw, seeing some of them inclined to speak, he cheers them on with "Rout him out! Rout him out! Rouse him, my beauties! Out with him, everybody!" And at it they go, more desperate than ever.

Forrester charges at a clump of bushes, and begins waving his stern like a soldier at signal drill. The huntsman keeps his eye on him, for he is a very clever hound at finding. $\mathrm{He}$ gives a whimper; his hackles are up. "Speak to it, Forrester! Speak to it, good boy." But Forrester will not lie, even to please the huntsman. In the meantime Bluebells, seeing Forrester about to speak, rushes past him, stoops to the line to make doubly sure, braces herself, lifts her head, and with one exultant cry of joy proclaims the find. The huntsman, cap in hand, cheers on the pack again with "Hark to Bluebells, hark to Bluebells," as she bounds away, joined by all the pack, who confirm her proclamation in one joyous chorus that makes the forest ring for miles around.

Yes, it is a stirring sight, one to make a hunting man's blood tingle to his finger-tips. Your true hunting man wonders how through it all some men can sit their horses and yawn and look bored, as wooden as a cigar-shop Indian with the whole block on fire behind him. Is our civilisation making women of us, that we no longer feel the sportsman's fire?

I pity a man who can look upon a sight like this and see nothing, or hear such thrilling music and ask, as I heard a man ask of a member of the Genesee Valley 
2 I 8 Cross Country with Horse and Hound

Hunt: "Ah, what are the dogs barking at, do you think?" - to which the member, whose ready tongue never misses fire, replied :

"Got a squirrel up a tree; you will see him come down in a minute."

"Ah, fancy! How can they ever expect to catch a fox if the dogs make such a noise about it?" 


\section{XX}

FARMERS AND CITY MEN 
“The farmer in front on a bonny grey mare

Is sailing along in the van;

He tackles his fences with plenty to spare, And trusts to the mettle that comes from Kildare, This sportsman who rides like a man."

POEMS IN PINK 


\section{XX}

\section{FARMERS AND CITY MEN}

OBLIGATIONS OF HUNTING MEN TO FARMERS - FARMERS' COMPENSATION AND DAMAGES - CITY MEN IN THE COUNTRY - SNOBS

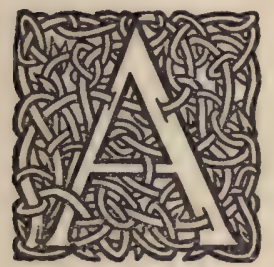

MAN may have the best hunter money can buy, the latest thing in hunting-togs and saddle equipments, hounds with the best noses in the world and the most "heavenly music"; but he cannot ride across a farmer's field except with the farmer's consent, given or implied.

Hunting men, especially city men, seldom appreciate the obligations the hunt is under to the farmers whose land they ride over. In the city signs of "Keep off the grass" or "No trespassing" are instinctively obeyed ; but let a man come down into the Genesee Valley, not alone and on foot, but with forty, fifty, or seventy men on horses, and go galloping across a farmer's meadows, and it is taken as a matter of course. The sportsmen think, perhaps, if they think at all: "Oh, the farmer sells his oats and hay and raises hunters which we buy at long prices. He ought not to complain." Surely one has heard some hunting man say this. They should be advised, however, never to repeat it ; for one thing, because the supposed compensation to the 


\section{Cross Country with Horse and Hound}

farmers does not amount to enough in a year to be worth mentioning. It is a basin of very old chaff; - small wonder the farmer only smiles sceptically but is never really appeased by such veritable nonsense.

So many writers on hunting have repeated this sort of thing so often that they have come to believe it. Their wishes are fathers to their theories. Yet it is a false doctrine which one should wish to see set right.

Can they mean to say that if hunting men did not move into a country the farmer would have no market for his crops?

"Of course not; but there is the sale of his hunters," they contend.

And are there no other animals he can raise? Is there no other market for hunters? Is theirs the only club on earth? They talk as if the farmer would starve if it were not for the sale of his products to hunting men. When they say the farmer ought to welcome the hunting men across his fields for what he gets out of the hunt, they insult his intelligence. Where do the hunting men buy their hay? Nine out of ten buy of the dealer in town. Their oats are ordered by telephone, and may never have seen the farmer's lands which the buyers hunt over. Nor is the hunting season the only time when the farmer can sell oats. As for hunters, nine out of ten are picked up by the dealers, who buy them, perhaps, for scarcely fifty dollars more than they would have had to pay for a farm-horse, no more than they would have to pay for a good coach or standard bred horse. No; all this talk about the farmers' compensation is only another instance of the parrot talk with 
which we become familiar in the course of a hunting career.

It is not for any imagined increase of revenue that the farmer allows the hunt to cross his lands, protects a litter of foxes in his fields, or takes mischievous puppies to walk. The foxes or the puppies alone cost him more every year than what he gets out of the hunting men over and above the regular price of farm products. A fox will kill perhaps twenty head of poultry in a single night. A hound puppy may destroy a twenty-dollar lap-robe in twenty minutes. The huntsmen smash his fence and leave his gates open, so that he and his men have to spend the rest of the day and half of the night, perhaps, looking for stray cattle or sheep. What compensation is it, what consolation, for the farmer to be told that he may get a cent or two more a bushel for a hundred bushels of oats, when the riders racing across his meadows frighten his cows so that the shrinkage in the flow of milk amounts to dollars? What is to pay him for the premature birth of the calf from his best cow, or of the lambs from the ewe that was raced into the corner of the pasture? It is his big heart, not his hope of small pennies, that makes him endure all this.

To be sure, there is supposed to be compensation for damages from the hunt; but not one farmer in ten, in America at least, ever demands it. No one outside of the farmer's family or the visiting neighbour ever knows of the damage. The Master himself, who knows a good deal, never hears the half, because farmers do not like to complain of amounts that are trifling, and keep still even when they may feel aggrieved and have met with serious 
224 Cross Country with Horse and Hound

injury to property. Mr. Austin Wadsworth, M.F.H., of the Genesee Valley Hunt, once told me that during the number of years he had been Master there he had paid out only a small sum, all told, for damages. No; hunting men are permitted to ride over farms because the farmer likes to see them enjoy themselves; even if he cannot afford to keep a hunter or take a half-holiday himself, he bids them welcome.

Few city men appreciate this welcome. Reverse the case and it would be another story. Suppose the owner of a furniture-shop in town had forty or fifty roughshod farmers periodically rushing through his shop, kicking over chairs, breaking mirrors, leaving the door of the varnishroom open till a cloud of dust made the new work to do all over again - how much comforted would he be to have them say they might buy a rocking-chair or two, and tell him he ought to welcome such good patrons and not be grumbling? The debt the hunters owe the farmers whose land they ride over is one of gratitude, and can never be reduced to figures. They pay a thousand dollars apiece for their hunters, a hundred for their hunting-suits, three cents a mile to the railway company to journey to the valley, and dollars or pennies to hotels, servants, or grooms. Every bill they owe, little or big, they pay to the last penny, or ought to; but none pays the farmer, directly or indirectly, for riding roughshod across his fields. It is really too bad to spout that musty speech about the farmer's pecuniary advantage from the hunt. One should rather speak out like a sportsman and own the debt; for, although he cannot square accounts, he can at least have a care. 
If not in coin of the realm, at least in courtesy the debt may be recognised. It is surprising to see how chary of thanks some city men are to their country creditors. Some of these are members of the hunt, they or their sons or both; yet how does the city man treat them when he meets them in the hunting-field? Many times as if they were beneath his notice. Such discourtesy is intolerable. City men who go into the country should do their best to prevent such snobbishness. Even if they do not care a toss of their heads for the feelings of the farmers or their own reputation among them, they should think of the Master, and for his sake make an effort to treat the country members of the hunt with gentlemanly consideration. Nothing they could do would please him better, unless it were refraining from riding on top of his hounds. A true sportsman, however unskilled at a game, is first of all a gentleman; the two terms should be synonymous. Your true sportsman and gentleman observes the golden rule. Youthful members of the hunt especially should look to it that they admire the proficiency of a fellow-hunter rather than his dress. They will often find that some of the best and keenest sportsmen wear old clothes, that some of the best horsemen ride longtailed horses and wear slouched hats, that a man with the best seat and the best hands sometimes goes with a toggled bridle and rusty saddle-irons, but is

A rider unequalled, a sportsman complete,

A rum one to follow, and a bad one to beat.

They should remember, in short, that as a rule farmers and farmers' sons know more about the art and science of 


\section{Cross Country with Horse and Hound}

fox-hunting than many of the men who dress and feel above them.

I must confess, too, there is more snobbishness displayed in the hunting-field in America than among the most fashionable packs in England. One great charm of hunting in England is the entire absence of snobbishness. Dukes and farmers, lords and merchants, meet for the day on one common level. Riding to covert you will see a former prime minister talking pleasantly to a tenant-farmer, a wealthy duke chatting with a horse-dealer, an illustrious knight asking the village cobbler for a match. I believe some townsmen in America would faint away if a farmer should ask them the time o' day. But an English gentleman sportsman is the most gentlemanly gentleman in the world, and perfect absence of snobbishness is one of his characteristics.

Edward VII, the present King of England, is, and as Prince of Wales was, a lesson and example in this respect to all snobs. If ever there was a genuine sportsman, His Majesty is one. He goes in for breeding pure-bred cattle and sheep, and his stock is seen at all the leading shows and fairs in England, competing for prizes against the country tenant-farmers. Neither King Edward nor the late Queen, who was also a keen breeder and exhibitor, ever exhibited anything except what was bred and reared on their own farms. They could have sent about the country to buy up a lot of prize-winners if they had wished, but their sportsmanship forbade such taking advantage of their competitors. The King's stock, sent to any fair, receives the same treatment as that of the farmer : is kept in the same stalls; and in 
the same ring, under the same conditions, wins or loses. It is no infrequent sight to see the King, as I saw him at the Royal Agricultural Show at York, go into an enclosure where fifty shepherds and farmers stand holding as many rams for his inspection, nor find it beneath his dignity to shake hands with tenant-farmers, to give a smile and a nod to a lad who has his hands full keeping a refractory ram in position, or a "thank you" to some old weather-beaten shepherd who holds a sheep while the King parts the wool to inspect the quality. It is said, and I can well believe, that His Royal Highness, as he was till recently, never looked so much a man as the day he placed himself on a level with the humblest competitors in the contest for prizes, and walked among them afterward, not as a prince, but as a farmer. One need not marvel at his great popularity, or seek long to discover what makes him one of the best-liked men in England. It is because the instincts of true sportsmanship direct every act

Lastly, I might add that the talented author of " Poems in Pink" agrees with me on this score of snobbishness, for he writes:

Leave us the chase, where, in harmony blending,

Men of all classes ride on to the end.

Men become brothers, each brother contending;

Every true sportsman is counted a friend. 



\section{XXI}

\section{THE LADY RIDER}


" Methinks I can see them - the mare she was riding, As bold as a lion, as meek as a dove;

The hunter so tame in the hand that was guiding

Its movements with kindness, its mettle with love."

POEMS IN PINK 


\title{
XXI
}

\section{THE LADY RIDER}

\author{
HER POSITION IN THE FIELD - HER HORSEMANSHIP - HER \\ COURAGE AND RESOLUTION - A FAMOUS RIDER
}

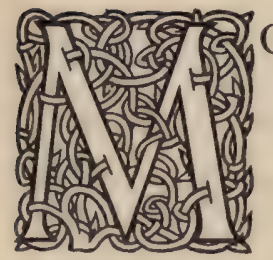

OST men, and at any rate all true sportsmen, agree in paying to the women of their race a chivalrous respect, constituting themselves at all times helping hands in little things and champions in great. There can be no rule without an exception, however, and the exception to the rule of romantic chivalry occurs when men and women meet in the way of business or on the hunting-field. When a woman enters business as a competitor with man, she puts herself on his level, and should, and in many cases does, expect him to treat her with neither more nor less consideration than he would show another man. She is in the game and takes her chances. It would be unsportsmanlike not to treat her in every way as an equal. If she loses at cards, a man should not, because she is a woman, count only three points against her when she has lost five; if she backs the wrong horse she should pay every farthing; and when she rides out to take her chances with men in the chase, she plays a game as truly as if she played bil- 


\section{Cross Country with Horse and Hound}

liards or cards. She understands that she is on the same footing with the other members, regardless of sex, and if she is the thorough sportsman which she often is in these days, she expects no favours, and men need not feel under obligations to give her any more attention or assistance than if she were one of themselves.

Precisely the difficulty with ladies in the hunting-field, however, is that men cannot seem to rid themselves of this notion of their devoirs. If a lady is just behind at a gap, for instance, they must halt and let her pass first. This is wrong in the end. They wrong themselves, and make her feel at last that she is a burden. If a gale of wind is likely to slam a gate against her, it should be let to slam. A man is under no obligation to put his horse in a temper or lose his position on this account. If she cannot manage the gate as he had to, let her be caught by it. This may seem a heartless, cold-blooded thing to say, but it is the attitude which, in the long run, conduces most to a fair rider's sport and pleasure.

One hears the unkind comment not infrequently, of course, that men are agreeable and generous in the drawing-room, but selfish the moment hounds begin running, and the fault is more with the men really than with the women. Men seem to feel they simply must be gallant. This is especially true of Americans.

Yet, in one sense, this is only to be expected, for a woman in the field is a constant object of wonderment or admiration. There is nothing that sets off a nice hunter as her figure does, nothing that adds more to the beauty and interest of the game than the presence of a goodly number 


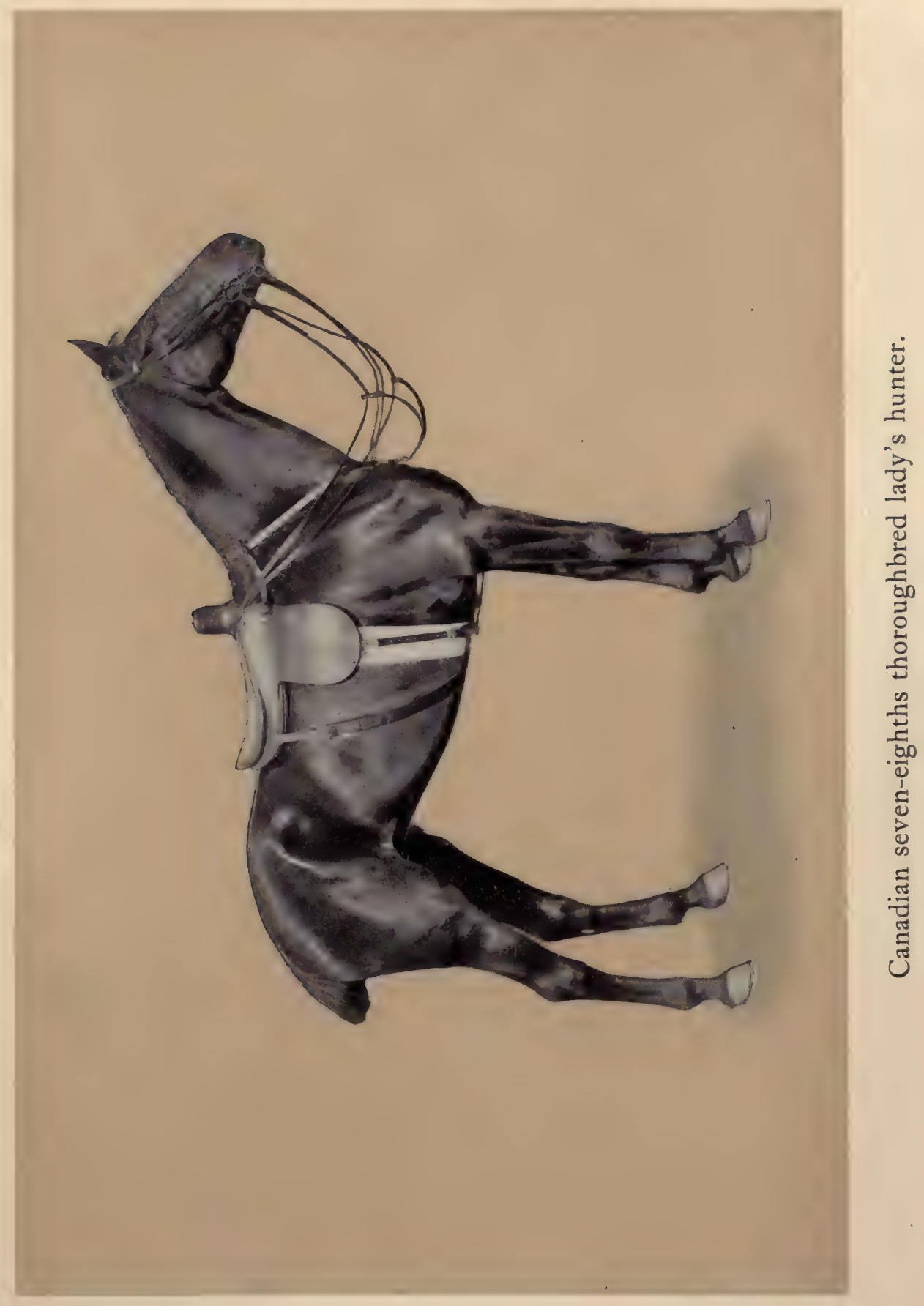



of ladies. They are totally unaccountable. They do the most reckless things, entirely oblivious of circumstances. Look at this Amazon with loose rein and horse rushing without let or hindrance through a piece of woods, her hair down and streaming out behind. You expect to see her skirts cling to some projecting prong of a tree, or her hair catch on some limb overhead. Away she goes, happy in the ecstasy of the chase. A check you think ought to find her face blanched; but you reckon without your host. Not she! She simply throws the reins down on the neck of her horse, which is quite willing to stand, being pumped to a turn, and begins with both hands to arrange her back hair, having previously filled her mouth with hair-pins. Her face struggles with smiles she cannot repress. And as the last hair-pin is released from between her ruby lips, she says to any one who may happen to be standing near, "Was it not glorious, that ride through the woods?"

Horsemanship is not a woman's forte, yet with those wonderful hands of hers she can manage many a horse with ease that a man would discard as a brute for pulling. Away she sails through footing good or bad, with the same free hand, leaving her horse to manage for himself. The lines are in her hands, it is true, but she seldom interferes with the bit.

Another beautiful thing about her riding is that her mount seems to be in perfect harmony with her ways. A sort of mystic understanding seems to exist between them; she seems to govern by some subtle power like hypnotism. She never irritates or worries or punishes him in any way. This, by the way, is one very important lesson to be learned 


\section{Cross Country with Horse and Hound}

from her. A man who rode in her style would be called a reckless daredevil, and probably be run away with every day he came out. The chances she takes successfully seem to suggest a charmed life, or strengthen one's faith in the good old doctrine of predestination.

Occasionally a lady rider exhibits a bit of horsemanship, but as a rule she is conspicuous for her lack of it, although, amusingly enough, she does not know it, nor does her mount seem to find it out.

"Some day," once said a young hunting man to me, "there will be a most horrible accident to a lady rider in the hunting-field, though may I never be present to witness it. She courts danger as she does admiration."

"I have been expecting it for the last sixty years," said an old hunting man to me in England, "but it never comes."

"She takes my breath away," remarked a friend of mine one day as we saw Miss F__ a most welcome addition to the Genesee Valley Hunt, send her faithful grey at a fence with a miry take-off and a big drop on the landing side. It was an awful scramble, but the blood of Wa-wazanda was in the old mare's veins. She had her own way, entirely unhampered, and in time we regained our normal respiration.

The same woman who would jump upon a chair in fright if a mouse ran across the room, or who would rather die than bait a hook with a squirming angleworm, will sail with apparently no concern at a stake-and-rider fence with a ditch on the landing side that makes us shut our eyes. They are enigmas, certainly. Their riding to 


\section{The Lady Rider}

hounds is an object-lesson, but their boldness springs not from bravery or pluck or nerve, but simply resolution. They have made up their minds to go, and whatever it is that stands for their nerve or courage is screwed to the sticking-point until the end of the run. I say all this with the greatest respect, of course, and mean no slur whatever. I remember once, upon my ship's arriving in the Bay of Fayal, Azores, passengers were obliged to go ashore in lifeboats in a sea that was running very high, and among them was a woman whose destination was Fayal. She was a peculiarly nervous type, just short, indeed, of the hysterical. During the voyage, if the great ship gave an unusual lurch or roll, she would scream in terror, and every one wondered how in the world she was to get down the narrow gangway and into the small boat, bounding up and down as it was, with no assisting hand. A person descending the ladder had to stop on the last round and wait until a wave of the right height placed the small boat on a level with the step an instant before it dropped again ten or fifteen feet into the trough of the sea. The captain, a Portuguese, in a comical state of anxiety to know how to manage this particular passenger, finally turned and walked away, fearing a scene. The key of the situation, however, was in her woman's head. A firm look of resolution settled over her face. She glanced once over the rail; then, with a toss of her head, walked to the ladder and, spurning all assistance, made the descent with less apparent concern than any man who had preceded her. Such was her woman's way. It was simply resolution, that set like a time-lock and carried her through. No doubt she fainted at the landing. 


\section{Cross Country with Horse and Hound}

At least one hunt in America has probably a dozen most accomplished horsewomen - the Toronto Hunt Club of Ontario, Canada. Nowhere have I ever seen so many brilliant lady riders to hounds. And, by the way, there is no prettier hunt club in America than this same Toronto Club. The club-house, in the natural forest, on a steep bluff on the shores of Lake Ontario, is one of the most delightful spots, planned and managed in the best of taste. The great charm of the place is that nature has been left severely alone. The paths are simply trails through the wood. The club-house itself is a model of convenience, and the arrangement and management of the kennels are superior to anything I have ever seen on the same side of the Atlantic.

One of the most enjoyable days to hounds I ever had in England was in the wake of an accomplished horsewoman. I had been spending a week in the Quorn country, and on the train for Warwick fell in with some hunting men, of whom I enquired with what pack they hunted and where the meet was. They hunted with the North Warwickshire hounds, it seemed, and the meet was that day at Kenilworth Castle. As I should be passing Kenilworth, I thought I would drop off there and look at the castle, which I had never seen, and also, perhaps, get a glimpse of my new acquaintances again at the meet at eleven. Though with little time to spare, I was so fortunate as to secure an excellent mount at a livery, a clean-bred thoroughbred whose rider had telegraphed at the last moment that he could not come. I slipped into my hunting-clothes, and was at the meet in the nick of time. It was a glorious day, and there 
were nearly two hundred riders present, whose pink coats lent an exhilarating colour to the picture. It so happened when we got off that I found myself striding along in the wake of the most artistic and accomplished lady rider I had ever seen. Besides a perfect figure, her seat and carriage were faultless, and she seemed to have an unusual amount of horse-sense or horsemanship, that most pleasing because one of the least frequent gifts among women who ride to hounds. Do what I would, I had to be content with a view of her back. We had a glorious gallop of twenty minutes or more straight away over beautiful meadows, as thrilling and brilliant a charge as one could wish, hunters to right of us, hunters to left of us. On rode my pilot, and well; bullfinch and ditch, timber and brook - I never had such a lead in my life. A check came none too soon, for our horses were done to a turn.

"Who is that lady?" I asked a farmer-looking chap, pointing to my pilot. He looked at me from head to foot.

"Don't you know who that is?"

"No; I am a stranger here."

"Bless you, sir! But every one in England knows that lady, or ought to. That 's the Countess of Warwick." Whose face, I must confess, was as beautiful as her figure, which was, in turn, as perfect as her riding.

I pulled out of the run to take the three-o'clock train for Warwick, and had a charming visit of sight-seeing at the castle. As the guide was showing me through, I asked to see some relics of Richard, Earl of Warwick, of whom I had read in Bulwer Lytton's "Last of the Barons."

"They are in the living-rooms," he replied. "If the 


\section{Cross Country with Horse and Hound}

family are away I may possibly take you in." He returned to inform me the countess was hunting.

"Yes," said I; "I have reason to know she is hunting. I had twenty minutes in her wake this very afternoon, and it was the greatest twenty minutes of my life in the saddle."

My praise of his lady so touched his heart that he showed me all through the house. It was an unexpected day, but one in which my cup was right side up from start to finish. I take the liberty to relate this little adventure freely by way of thanks for courtesies received and in tribute to perfect riding.

One thing that spoils many riding men and particularly makes miserable many riding women is that the moment they are accomplished enough to keep to the front, jealousy of the accomplishments of others springs up in them. They begin to talk about how they cut down So-and-so, and fish generally for compliments. The women, at any rate, get them, of course, which only intensifies their spirit of emulation, and sooner or later will mark the end of their riding. Yet, with all the lady rider's faults, we love her still. May she never cease to grace the hunting-field with her presence. She certainly has a charmed as well as a charming life in the saddle, and I, for one, welcome her ever if she knows that every woman is a man in the hunting-field, and that it is every man for himself, with his Satanic Majesty to look after the hindmost. 


\section{XXII}

\section{MIND-POWER HORSEMANSHIP}


"I said to myself, it is hard to believe, But yet as I look I can plainly perceive, In the dash of the horse that is leading the van,

The workings that come from the mind of the man." POEMS IN PINK 


\title{
XXII
}

\section{MIND-POWER HORSEMANSHIP}

\author{
"AN INDEFTnable SOMETHing" - PERSONAL MAgNeTISM - \\ CONSENT TO BE GOVERNED - CULTIVATION OF \\ MIND-POWER CONTROL
}

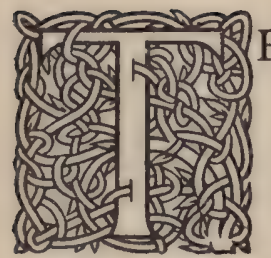

HERE seems to exist between man and beast a certain force by which the former is able to exert over the latter some subtle influence to which various names such as "bond of sympathy," "an indefinable something," are occasionally given. So far as I am aware, no writer on hunting has attempted to advance any hypothesis which may reasonably account for the source of this power or define its scope and limitations.

We hear it said that dogs and horses love certain people because these people love them, and that this love itself explains their control over horses or dogs. "All dogs take to me," one person says; "I don't know why it is, but I can make them do almost anything." And, indeed, some persons easily teach a dog or a cat or a bird a trick which another would require weeks to instruct them in, if he did not fail altogether. Yet, while it is true that a person who loves animals is more likely to train them easily, 


\section{Cross Country with Horse and Hound}

the power cannot be attributed to love, for often an entire stranger can make an animal do things which the owner, who loves the creature dearly and is in turn dearly loved, fails to accomplish. One man will take a horse that he has never seen or ridden before through a cross-country run to hounds, and bring him in at the death without exhausting him as much as his owner would, although the latter may be as good a horseman and lighter in weight. Every hunting-field affords examples of this, which cannot be accounted for by difference of horsemanship. Writers on hunting all agree that some men can make a horse do most incredible things, and attribute this wonderful power of control to "better hands," "better seat," or what not. It must be admitted that a person with very bad hands or a bad seat, or both, may irritate a horse and take more out of him in a run than a man with perfect hands and seat; but an explanation on this basis does not account for the fact that a better rider and a lighter can come through a run with the better-conditioned horse pumped to a turn, while another man who has ridden the same line brings his horse in comparatively fresh; or that two such men may change horses in the next run and find the results change too. The fact has been demonstrated so often in every hunting-field that I need not enlarge upon it, except to say we must look further than any theory as to hands and seat, or of the power of love, in explanation of such phenomena.

Most of my readers have doubtless seen, at exhibitions throughout the country, examples of the wonderful control some men have over animals, the wild becoming tame, the 


\section{Mind-power Horsemanship}

nervous quiet, and the vicious tractable under their magic influence. Such things are sometimes explained by the sceptics as the results of "doping." From personal knowledge, however, as a pupil of Rarus, and from personal acquaintance with the late Professor Norris, and since with his son Mr. Stuart Norris, who is following in the footsteps of his illustrious father in the training and exhibition of trick horses, I am positive in saying that there is absolutely no foundation in attributing to this " doping" theory the wonderful power of control which these men display.

Let us see if an attempt to puzzle out or analyse this power will not result in establishing its source. We may start with the assumption that the numerous terms in common use to define this power - "charm," "gift," " personal magnetism," "will power," " natural instinct " - go to show that its existence is recognised beyond doubt or question. An analogous power of control existing between man and man is familiar under the names of hypnotism, magnetism, mesmerism, or kindred mind-power manifestations. All mind-power manifestation, under whatever name, is, I believe, subject to one universal condition, namely, consent. The resemblance between the terms generally adopted in attempting to describe the power that some men have over their mounts, and the terms by which we try to describe hypnotism and other mind-power manifestations between men and men, is significant. One set of words applies just as fairly to the power some men are capable of exerting over some other men as they do to the powers which great animaltamers or our peculiarly gifted horsemen have over the animals they bend to their wills. That some men possess 


\section{Cross Country with Horse and Hound}

this power over animals and are unconscious of exerting it is no proof that the power does not exist. Hypnotism, though old in essence, is in practice very lately out of its infancy, yet making vast progress. Several physicians of my acquaintance are making use of it with most satisfactory results, even employing it in place of antiseptics when performing dental and surgical operations. So rapidly has this subject developed of late in the medical world that one of the most successful physicians of to-day says: "Within ten years from now no student of medicine will be considered master of the profession unless he is able to command this power." If this mind power between man and man is the same as that between man and beast, we have probably what may be termed a working hypothesis covering the whole field and reasonably accounting for many otherwise unaccountable things in the way of horsemanship.

We noticed, under the subject of mind-power manifestations as between man and man, that the one common factor prevailing in all is consent, which has its parallel in the relation between man and beast, called by whatever name. In all hunting countries there is a saying that in order to be successful in horsemanship one must first get on good terms with one's mount. Getting on good terms with a horse is merely obtaining his consent to be governed. If these things be true, it brings us to the conclusion that this power emanates from the same source, whether exercised between man and man or between man and beast, and the working hypothesis we have set out to establish may be summed up as follows: (I) there exists a mind-power control between man and man; (2) there exists a mind-power control 


\section{Mind-power Horsemanship}

between man and beast; and (3) the power of control is the same in both cases.

This brings us to another point purposely omitted until now, namely, that while a person or a horse may be willing to be acted upon, the person seeking to control him must be desirous of doing so. In all hypnotic demonstrations there must be harmony, accord, or what the French term rapport. Further, this power, or desire, (I) exists in every person to a greater or less degree; (2) it is, like other faculties of the mind or body, subject to cultivation or development, and, like them, increases with use ; $(3)$ its manifestation is in a degree proportionate to the will of the one or the faith or confidence of the other.

I shall not attempt to advance any evidence to sustain the theory of mind power in the case of man and man, as that is universally admitted. As to the power of control of man over animals, I may be pardoned for stating a few facts that have come under my observation. I once had for a stud-groom a North-of-Ireland man, Peters by name. $\mathrm{He}$ had very heavy hands and his seat was something shocking, on account of which I seldom permitted him to mount a colt or hunter. When, however, he did go out, I was always struck with the fact that he brought his horse home in better condition than any other groom I ever had. During all the years he was in my employ, I doubt if he ever struck one of the twelve stallions which during that time were under his entire charge. One of them, Macbeth, a thoroughbred, was, as I learned after he came into my possession, a man-killer. He had killed one stable-man, and several others had had very narrow escapes from his 


\section{Cross Country with Horse and Hound}

vicious temper. I had an experience of my own to show that Macbeth had not improved in temper, when I was driving one day, with another man than Peters leading him behind a two-wheeled top-cart, to a stallion show at Geneseo. The vicious beast suddenly reared and struck both fore feet through the leather top of the cart, which was up at the time, evidently with most wicked intent, tipping over the trap and throwing us both into the road. The whole top of the cart was torn off, the stallion's feet fast tangled in the bows of the top. That we were not killed was no fault of the stallion. When, however, Peters arrived upon the scene, the savage beast, seemingly at a word, became as quiet as a lamb, allowing himself to be handled and led away by his groom under perfect control. Probably every one who has had much to do with horses can cite similar experiences from his own observation. Whence comes this power, this magic influence?

This interesting subject was first forcibly suggested to me by the actions of an old favourite driving-mare. She had been in my family many years, and, it is safe to say, had been in harness or under saddle on an average of once a day during all that time. A few years ago we began to notice that when Sunday came the old mare would turn of her own accord toward church, and that if I was going to a train she invariably turned in the direction of the station. Her usual errand to town was to the post-office, where she probably went nine times out of ten. The station required a turn to the left, the church a turn to the right, while the post-office was farther on in a direct road. We have assigned many reasons for this seeming intelligence on 


\section{Mind-power Horsemanship}

the part of the old mare, but none of them except that of the mind of the rider or driver's having some influence over her action fits all the circumstances. With this suggestion, I began one day to go over my experience in the saddle, and the education of colts and the schooling of hunters, and I came to the conclusion that this mind-power theory gives the only satisfactory answer to many knotty problems concerning horses and horsemanship. For instance, in hunting it is everywhere noticeable that, when ridden by some men, horses that are only soft green things or colts come out of a run in remarkably fresh condition as compared with some old seasoned hunters that are, as they say in England, "as hard as nails." Some heavy men, those who, for example, ride at a hundred and eighty or two hundred pounds, bring their horses in comparatively fresher than those ridden by lighter men and better riders. I am persuaded that this better condition after a hard run cannot be accounted for by hands or seat. Again, it is the experience of some riders that they can ride a horse through a severe run with the least possible fatigue to themselves. I have always been rather shy about saying it, because it seemed contrary to reason; but I am going to say it now : I can ride a horse fifty, sixty, or even seventy miles in a day, which shall include a run to hounds, and not feel more fatigued at the end than from a ride of ten, twelve, or eighteen miles in a carriage; and I find now and then a person who reports a similar experience. I believe this is owing to a mutual compensation between rider and horse. I have also remarked that when I watch a run from a carriage I go home quite worn out. I help, in imagina- 


\section{Cross Country with Horse and Hound}

tion, every horse I see jumping, that is to say, ride each one, mentally, just as if I were on his back. After an hour of this sort of riding I am quite fatigued. I believe that it is due to the fact that I have not actually had a horse under me from whom to receive the necessary compensation.

May it not be this very power we have been discussing, more than " hands," that makes a horse stop pulling as soon as a person has been up long enough to obtain the animal's consent to be governed? This is not, of course, to say that a man who has a bad seat and is all the time nagging at his horse's mouth can by the mere exercise of his will make his horse cease pulling. We hear everywhere "hands" called a gift, truly enough; but may good hands not owe their existence more to a gift of mind power than to mere skill in handling? May it not be owing to this mind-power control over animals that many lady riders have over their mounts what, in the absence of horsemanship, we call a "charmed life" in the saddle?

We hear everywhere among hunting men a great deal about lifting one's horse at a jump, the expression, which is a common one, conveying the idea that this is done by an actual pull at the bit. Never was a more absurd notion entertained. One might as well say a man could climb a pole and pull the pole up after him. If the phrase, however, means that by the mind power of control a man can assist a horse, I do not dispute it, for it seems to me that, from the very use of the expression so frequently, riders are conscious of rendering great assistance to a horse at the moment of going over a fence. It is by a lift, to be sure, 


\section{Mind-power Horsemanship}

but by a lift of the will, or by the mind's power of control. In the case of the heavy-weights who in every hunt club get across country with more ease to themselves and to their mounts, and with less fatigue to both, than many of the lighter men, in spite of all sorts of reasons assigned, may not the truth be that such riders, conscious of their weight, in some way aid their horses by their mind's power of control?

I never yet met a hunting man, or any man who had much to do with horses, who did not believe that a rider, by losing his nerve at a fence, almost invariably caused his horse to refuse the jump. Conversely, if it is admitted that a horse can be influenced by fear in the mind of his rider, why should not the animal feel the effects of the opposite mental state, namely, confidence or courage on the part of his master? What means can a horse possibly possess of feeling the state of his rider's mind which do not equally apply to the interpretation of any of the other power manifestations we have mentioned?

The great T. Assheton Smith came very near hitting the nail on the head when he said: "'Throw your heart over the fence, and your horse will follow it." I would respectfully beg to amend that saying, in the light of mind-power control, by making it run: "Throw your horse over the fence, and stay with him the best way you can in the flight."

We have attempted to show that there must be not only consent on the part of the mount, but will on the part of the rider, to insure control; that some men can ride a horse as if he were an engine, the horse, in such a case, 


\section{$25^{\circ}$ Cross Country with Horse and Hound}

having no assistance whatever, since none can be had without the desire to give it. The next point is, how can one train a horse so as to have over him the power of control to which I refer? I reply in two words - by confidence. Confidence presupposes consent. To obtain that end, there must be an entire absence of fear on the horse's part. I have not struck a horse or colt with a whip in fifteen years, except, perhaps, a crack of the crop when he was going at his fence in a shifty gait that showed he was in a changeable state of mind.

In schooling a horse, there is nothing, as I said in the chapter on training, like throwing him down. It does not hurt him or frighten him, and from that moment he has the greatest respect for you, and begins to believe in you. $\mathrm{He}$ has seen a practical demonstration of your power. You are, in other words, obtaining his consent to be governed.

In advancing a theory of mind-power horsemanship, I have given free rein to what is not, I am convinced, altogether fanciful speculation, in the hope that readers, once their attention is directed to the subject, may be induced to experiment on their own account. If the hypothesis stands the necessary tests, it may teach horsemen practical lessons, to the mutual advantage of themselves and their mounts. For myself, I believe that such a mind power of control does exist, in greater or less degree, in nearly every one, and is undoubtedly susceptible of cultivation. At any rate, when one considers its efficacy, as powerful as it is subtle in given instances, the least that can be said of it is that it is worth trying for. 
XXIII

DRIVING TO HOUNDS 
" Oh, bear me, some kind power invisible, To that extended lawn where the gay court

View the swift racers stretching to the goal!" SOMERVILLE 


\section{XXIII}

\section{DRIVING TO HOUNDS}

AN INTERESTING PASTIME - THE DOCTOR AND THE LITTLE MARE - A REMARKABLE SPILL

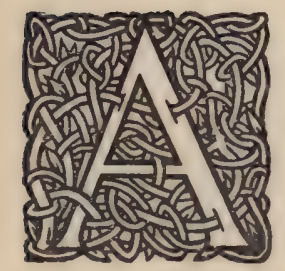

BOOK of this kind would hardly be complete if it failed to mention an interesting if not an exciting feature of hunting; that is, the viewing of the chase, or as much of it as may be possible, from carriages driven along the highway. As most persons' introduction to hunting is accomplished in this way, I venture to take a drive with my readers through such a first run, and I cannot better do this than by giving an account of my own first acquaintance with the sport.

Early in the eighties it was my good fortune to move into that beautiful and fertile section of country known as the Genesee Valley, and to see soon after a hunt for the first time in my life - the famous Genesee Valley Hunt, riding cross country to hounds. My ideas of fox-hunting had hitherto been of the vaguest. I remember thinking that all other ways than going after foxes with a gun must be unbecoming to a sportsman.

My good friend the Doctor invited me one day to ride 


\section{Cross Country with Horse and Hound}

out with him to see a fox-hunt. The thought of going hunting in a buggy was quite foreign to my ideas of sport, and I had less than half a heart in accepting the invitation. The Doctor, on the other hand, was brimful of enjoyment. He was not a riding man himself, the large rotundity of his figure forbidding any activity in the saddle, but a keener sportsman or a more enthusiastic one it would have been hard to find. The meet was at the Hermitage, and we were, unfortunately, too late to see the assembly. Hounds had gone on to draw the Hermitage Wood. The doctor was in a great state of agitation to think we had missed the meet. However, we drove down the farm lane behind the Fitzhugh manor-house, with a mere chance of their coming north. In the meantime the good Doctor expatiated to me on the subject of this "grand pack of hounds," this " oldest hunt," " best horses," and " best cross-country riders in America," working himself up to a higher and higher pitch because I responded only in the most indifferent manner. He tried harder and harder to make me appreciate the splendid opportunity I was enjoying. All at once he brought his little black mare Kitty to a standstill and listened.

"I hear them!" he shouted, and stood up in his buggy - a little side-bar spider-like trap. I remember thinking what would the Doctor do on a runway after deer or wild turkey in the great forests of Michigan, if he made all this fuss over a fox.

"I do believe they are coming this way!" cried the Doctor. "Don't you hear them ?"

"Sit down!" I cried, "or you will be out on your head." 
I hoped no one would see us, for surely the Doctor would have been thought crazy or drunk, he was so completely transformed from his usual dignified manner. When he entered a patient's house or walked the streets he carried himself like a churchwarden taking the Sunday collection; yet, to see him now, one might have thought him a boy of eight waiting for his father to come home with fire-crackers and punk for a Fourth-of-July celebration.

"I believe they are coming this way!" And again the Doctor stood up, and I looked round to see if any one could see us.

"I hear them!" he cried at last; and then he clutched me by the collar for support, and stood up on the cushion. I expected every moment to see him lose his balance and go headlong. It was a sight to make one tremble - two hundred and twenty-five pounds and six feet balancing itself on the cushions of a side-bar buggy and gesticulating wildly.

"Sit down!" I cried. "Your mare will start and pitch you out."

He stepped down at last, and called to his great pointer Sancho to jump into the waggon. There stood the little mare, with ears sharp ahead, and the pointer with his fore feet on the dash-board, looking first into the Doctor's face and then in the direction indicated by his extended finger.

"Here they come! Here they come!" shouted the Doctor, as a dozen hounds came tumbling over the fence on the far side of a great level meadow. "Here they 


\section{Cross Country with Horse and Hound}

come!" And twenty couples or more came charging across the field, followed by thirty-five or forty riders.

Instantly, I must confess, I was carried away with delight. There could not be a prettier picture of a hunt. On came the hounds, heads down, working like pointers along the line across the field directly toward us. They were upon us in a moment, jumping from the field into the lane and out of the lane into another field within a few rods of where we stood. The Doctor put about, and away we raced little Kitty out of the lane, into the highway, and down the road on a dead run. The mud flew like sparks from a pinwheel twenty feet in every direction, plastering our backs. "No matter; rub it off when it gets dry!" cried the Doctor. "We must have another view."

Presently up behind us came Miss F- with a friend, a lady, driving a pair of thoroughbreds harnessed to a buckboard, the horses running as fast as they could lay foot to the mud. The sight of these young ladies as they passed us, the lines lying loose on the backs of the charging steeds, was enough to electrify a stone.

"That 's the sort!" shouted the Doçtor. "Go on!"

A smile and a nod, and away they flew again. The Doctor let out another link in the little mare's speed, and, be it said to the credit of the gamest bit of horse-flesh of her inches I ever saw, the little mare raced on for half a mile to the turn in the road to Mount Morris, setting the pace for Miss F__'s thoroughbreds.

A dozen carriages were waiting at this turn. The hounds were at fault only a moment, however, and finally crossed the Mount Morris road and went straight along 


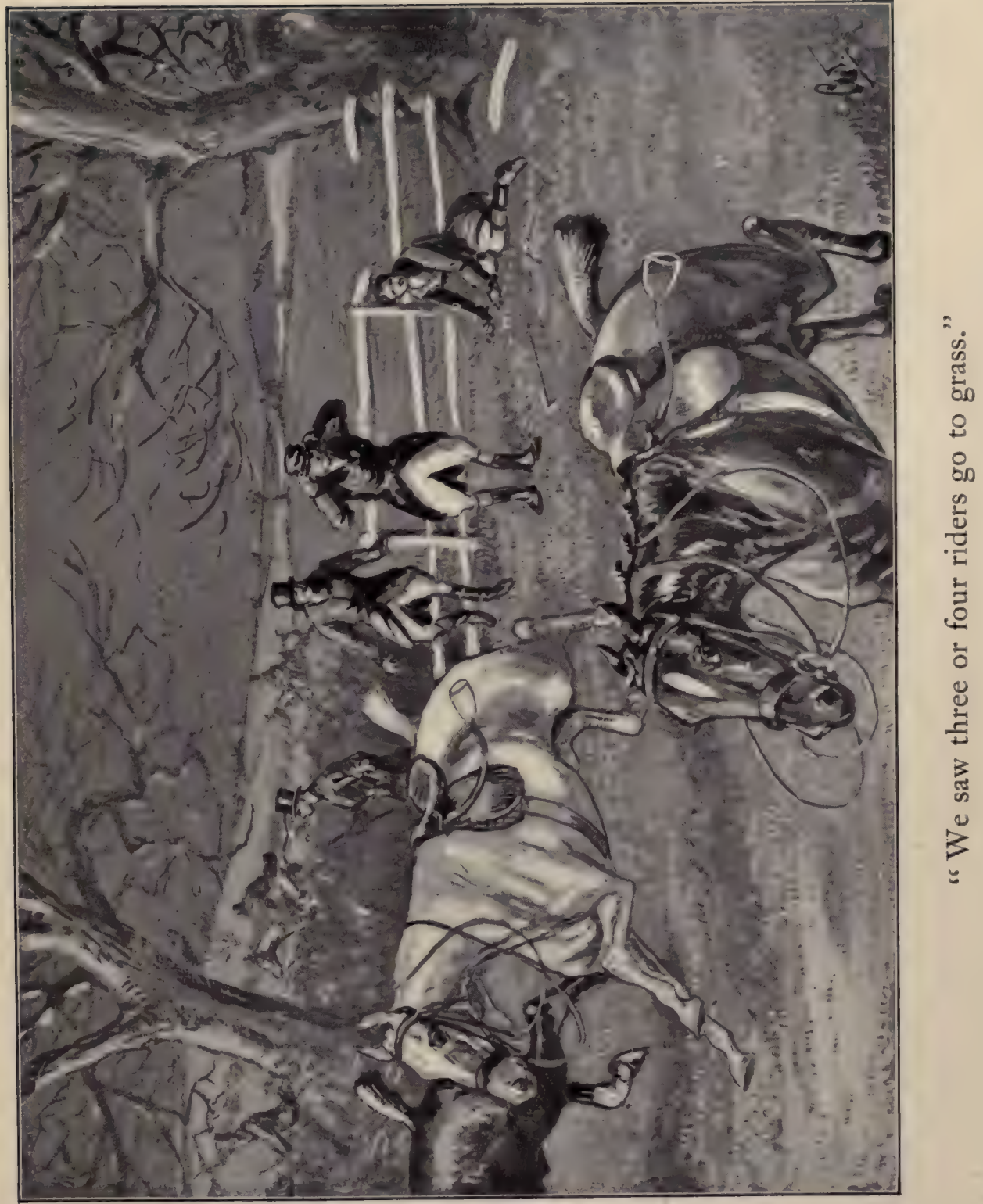



the east side of the river toward Geneseo. On rushed the Doctor, the pointer, with his fore feet still on the dashboard, barking at every one we passed. Crossing the highway on to the Able farm, we saw three or four riders go to grass. On went the huntsmen. On went the carriages, strung out like a funeral procession for length, but all with horses galloping madly. And on raced the Doctor, until he headed the procession. I have been run away with several times, but I never again travelled so fast in a buggy as I did on this wild occasion. In jumping into the highway crossing the Geneseo road, some one with his horse's nose drawn down into his chest caught his mount's knees on the top rail and turned a complete somersault; and incidentally I learned the most useful lesson to be taught in the hunting-field. It was plain even to my inexperienced eyes that the horse was thrown by its rider.

On a little farther we assisted at an extraordinary performance, and brought our race to an end. A pair of farm-horses which were attached to a lumber-waggon with an empty box became frightened at all the hue and cry, and ran away toward Geneseo. They were flying along the edge of the beaten track just ahead of us, when suddenly, the right fore wheel striking a large stump on the side of the road, up went the box free of the waggon, described a somersault through the air, and landed on the ground with the farmer under it. The horses never halted. The Doctor and I, when we arrived at the overturned box, could hear the farmer underneath yelling like an Indian. We jumped out of our waggon, and on tipping up the box out came the farmer on his hands and knees, white as a 


\section{Cross Country with Horse and Hound}

sheet but not injured in the least. I record this as the most extraordinary thing I ever beheld, and as an exaggerated instance of what one may see driving to the hunt.

As for the Doctor and me, we were a rare sight. We dug the mud out of our necks and ears and eyes, and started for home, telling each other over and over again the events of the day. The gamy little mare that drew us came in for no small share of our comments. There would come a pause, when the Doctor's face would kindle and he would break out laughing again with: "But how the little mare did go!"”

Thus ended my first drive to hounds. Needless to say, it was not long before I had out a saddle and began practising jumping on my own account. I got a saddle on a driving-horse back on the farm, and had my first jumping lessons out of sight. My early training at bareback riding stood me in good stead, and before I was much older I was by way of becoming a hunting man myself. I practised with more and more enthusiasm till my good wife heard of my doings and interposed.

"Now you must promise," she protested, "you will never ride in the hunts."

A hand clinched each lapel of my coat persuadingly, and after some hedging I found I had no alternative but to promise.

I took her to see a run herself one day not long after, and my lady was enthusiastic. "What beautiful horses!" she exclaimed. "I wish you had one for me to ride." I promised readily to get one. Fortunately we had seen no falls. "Ah, if I were a man," she declared, "I should have to ride." 


\section{Driving to Hounds}

I suggested warily that although she was not a man I was, and that -

"Now stop," she interrupted. "I believe this is all a trap just to get my consent."

"It's a trap, maybe, but you 've walked into it unassisted, Madame," I had the pleasure of retorting. May every married man succeed as easily as I did in getting his wife's consent to his hunting!

I never forgot, however, the excitement and interest of driving to hounds, which can be recommended as rare sport and diversion for all who for any reason cannot ride. It affords one an abundance of exciting spectacle and, if one keeps an eye alert, not a little instruction in the points, both major and minor, of cross-country riding. 



\section{XXIV}

\section{OFFICERS AND HUNT ASSISTANTS}


"The huntsman in front on the bay

Flies on like a boy at his play.

$\mathrm{He}$ counts the good pack speeding over the plain,

And grins as he looks for a skirter in vain.

He says to the whip, "They are at it again,

Hark forrard, hark forrard away.'

POEMS IN PINK 


\section{XXIV \\ OFFICERS AND HUNT ASSISTANTS}

THE M.F.H. - THE HUNTSMAN - THE WHIPPERS-IN - THE KENNEL HUNTSMAN - THE EARTH-STOPPER

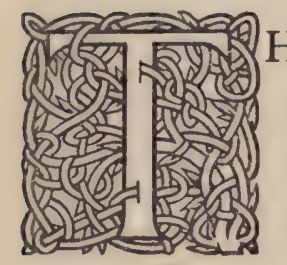

HE office of Master of Foxhounds has never reached the exalted rank in America that it has in England, but the duties of the office are for the most part the same in both countries. Few people, even a large number of those who ride to hounds, have more than a confused idea of what these duties are. Enough has already been said on the question of the breeding and management of hounds to show that in this field alone they are no trifling matter. In addition there is the oversight of the breeding of horses, invariably accompanying an established hunt, as well as many social duties and a large correspondence. There are also the various executive duties involved in the administration of hunt affairs. The enormous expenses of at least one hunt in America are borne by the M.F.H., who not only owns the hounds, but pays all the bills involved in running the stud and kennels, the members of the hunt paying only a dollar a year each. The expense of a hunt club cannot come far short of five hundred dollars for every day that hounds hunt. 


\section{Cross Country with Horse and Hound}

Enough has also been said about horse-breeding to show that although it is in no way to be compared with houndbreeding it is no small item in the account where the Master undertakes not only to provide himself but also the huntsman and whippers-in with mounts - three or four each - and have half a dozen extra horses for bye-days and for friends and guests. No one who has seen an M.F.H. in the full discharge of his social and official capacities, or recalls what he has done in the breeding and development of the hound and the management of the pack, can fail to appreciate ' his labours or help being stimulated to make them as light as possible. We shall see the Master in his official capacity at the consultation of war and at the covert-side, and at the meet as well as at the hunt dinner in his social aspects.

Of the huntsman it has been said that "from the fox he learns cunning, from the hounds sagacity," which indicates the combination of qualities necessary in him. Occasionally a Master hunts his own hounds, but more often a salaried huntsman is employed, one whose long years of experience as whipper-in make him a past master in the art. His qualifications, like those of the hounds that assist him and the horse that carries him, are of a high order. He plays against the craftiest and longest-headed animal of field or forest. Every plot of cunning Renard to elude his pursuers the huntsman must meet with a counter-plot. He must have the woodcraft, the ear and nose, of an Indian.

Most huntsmen, we believe, prefer to approach covert " down-wind," for two reasons: first, since no sportsman wishes to have a fox "chopped" in covert, to give the fox timely warning; second, because, while a fox is a very 


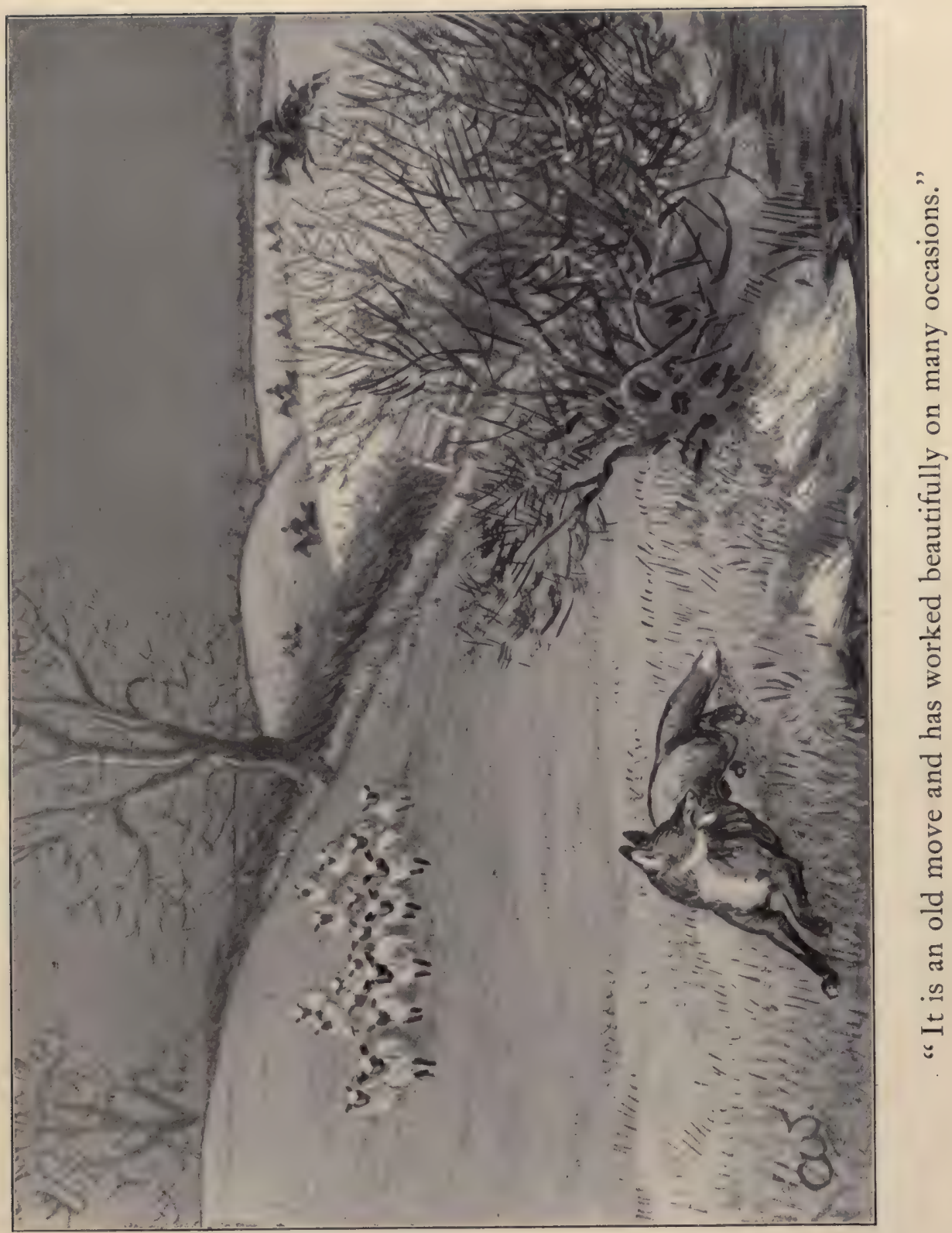





\section{Officers and Hunt Assistants}

timid animal and almost anything turns his course once he is on the way, he hates to break covert, and will often return to it even if he has to run among the riders and the hounds themselves to accomplish his purpose. In the former case, of course our huntsman has sent the first whipper-in ahead to take up a position on the opposite side of the covert in the best position attainable to view a fox away when he breaks. Approaching covert downwind also affords him an opportunity to go away in the other direction,- - up-wind, - which, giving him more timely warning of approaching danger, is his natural way of travelling. Leaving very little scent behind him when he begins to travel and when sleeping quietly, the fox seems to know that hounds may fairly run over him without detecting him, and the huntsman finds it very important to make the best of a light scent on a day when scent is likely to be poor. In such cases the covert is drawn upwind, to get the hounds as close on their fox as possible. It is considered justifiable by most huntsmen, when the first whipper-in or a rider views away a fox under such conditions, to "lift" the hounds on, out of covert, as quickly, and lay them to the line as far ahead, as possible. The fox may have broken covert up-wind, but it is only a matter of time when he turns short down-wind, probably owing to his being persuaded that since he really is pursued, it is the better part of valour to trust to luck for what may be ahead and put himself sharp down-wind in order to keep the longest ear to the hounds and what is coming after. A fox is crafty in this also, that he dislikes being made to do anything not in his first matured plan. This 


\section{Cross Country with Horse and Hound}

usually is to reach security in the nearest earth or covert, and therefore in changing his course down-wind he runs at a distance determined by the extreme limit of his hearing powers. Then when hounds check he can generally stop running, and if not pressed turn at last to make the point he had in mind when he left covert. It is for this reason knowing riders when they arrive at covert take up a position, if possible, on the down-wind side, especially if Renard went away at all across the wind; - all of which goes to show that a huntsman must form quickly an idea of the plans working in the mind of his hunted fox. The conclusions to be drawn from the way he left covert; from the scent in the first few fields; from his age, sex, and condition for running; from a hundred and one things a novice would never think of looking for, must be to him an open book.

A keen huntsman, from the characteristics of every hound in the pack, learns in the first half-hour much as to the special tactics he will have to deal with in his fox. Perhaps the fox is a "ringer," one the huntsman thinks he has chased before, since his plan is identical with the last one they chased from this same covert and lost; and he is ready, from experience, with his counter-plot. Thomas Smith gives an account of a huntsman who, on finding he was for a second or third time after a ringer, stopped the hounds, went the other way around, and met Mr. Renard face to face. They viewed him away, and in due time he was sent to the land of his fathers. An experienced huntsman seems to know instinctively when the hounds are at fault. 
After the manner of chess-players, Renard and the huntsman first try the ordinary moves of the game, such as, on Renard's part, running in rings, or trying for some open earth he knows. In this case the earth-stopper also knows about them, and, directed by the huntsman, has been there during the night - while Renard prowled the country -and stopped them. Again, if Renard runs to and finds an open earth, especially in the beginning of a run, he may not really enter it to stay: he would like, of all things, to have the hunt stop and dig him out when he is miles away. In this case the huntsman's move is a wide, careful cast about the earth till the hounds discover the line again and are off. These are preliminary moves. Later in the game he will break straight away for some distant covert where he knows for a certainty a particular fox, a friend of his, always kennels in the day. With a wink of "the other eye," he flourishes his brush at the hounds and sails straight for that particular covert. Awaking his friend from a sound sleep, he gives him an account of a thousand hounds that are coming after, says he just dropped in to give a timely warning to run for life, and away also goes his friend, the first hunted fox slipping quietly to one side and lying down to rest. It is an old move and has worked beautifully on many occasions. But the huntsman also knows a thing or two; he has noted that the older hounds hesitated at a certain point, while the younger ones took up the line. This can have only one interpretation. "Toot-toot!" he goes on his horn, and the whippers-in are off like shot out of a gun to head off the pack and turn them back to where the huntsman calls them. 


\section{Cross Country with Horse and Hound}

"Get back, Browso! Back, Smuggler!" shout the whippers-in, with much cracking of their double thongs.

The instant the hounds are collected, the huntsman takes them back to the point where the older hounds hesitated. Sure enough! Tinbush hits off the line of the hunted fox with a cry of joy that brings every hound to her side. Away they go again, making the forest echo with the clamour of their musical tongues.

Meanwhile Renard has been having a rest, enjoying his laugh at the hounds and his good joke on his friend. Now he hears the pack returning, and begins to realise his scheme has failed. Yet he has caused a check and recovered his second wind. With another flourish of his brush, another knowing look, he steals away along the furrow of a halfploughed field. On goes the chase. Again the hounds are getting too near for comfort. Renard now stops, jumps as wide as he can to the right, runs on a little way, and lies down again; or runs back in the very tracks he came in. The hounds coming on at a fearful pace go a hundred yards or more over the end of the line. Their heads go up, their music ceases. Again they are at a check. But the huntsman, not checkmated yet by any means, recalls that a little way back Bluebells made a sharp fling to the right. He said "I thought so" perhaps, at the time, but always lets his hounds make their own cast first to see what they can do without his assistance. He blows his horn again, and, with a wide cast back to where Bluebells made her drive to the right, the pack again hits off the line. Again Mr. Renard says, "Good day, gentlemen; I see I must be moving," and trots off in a leisurely way until he hears the pack once more upon his line in full cry. 


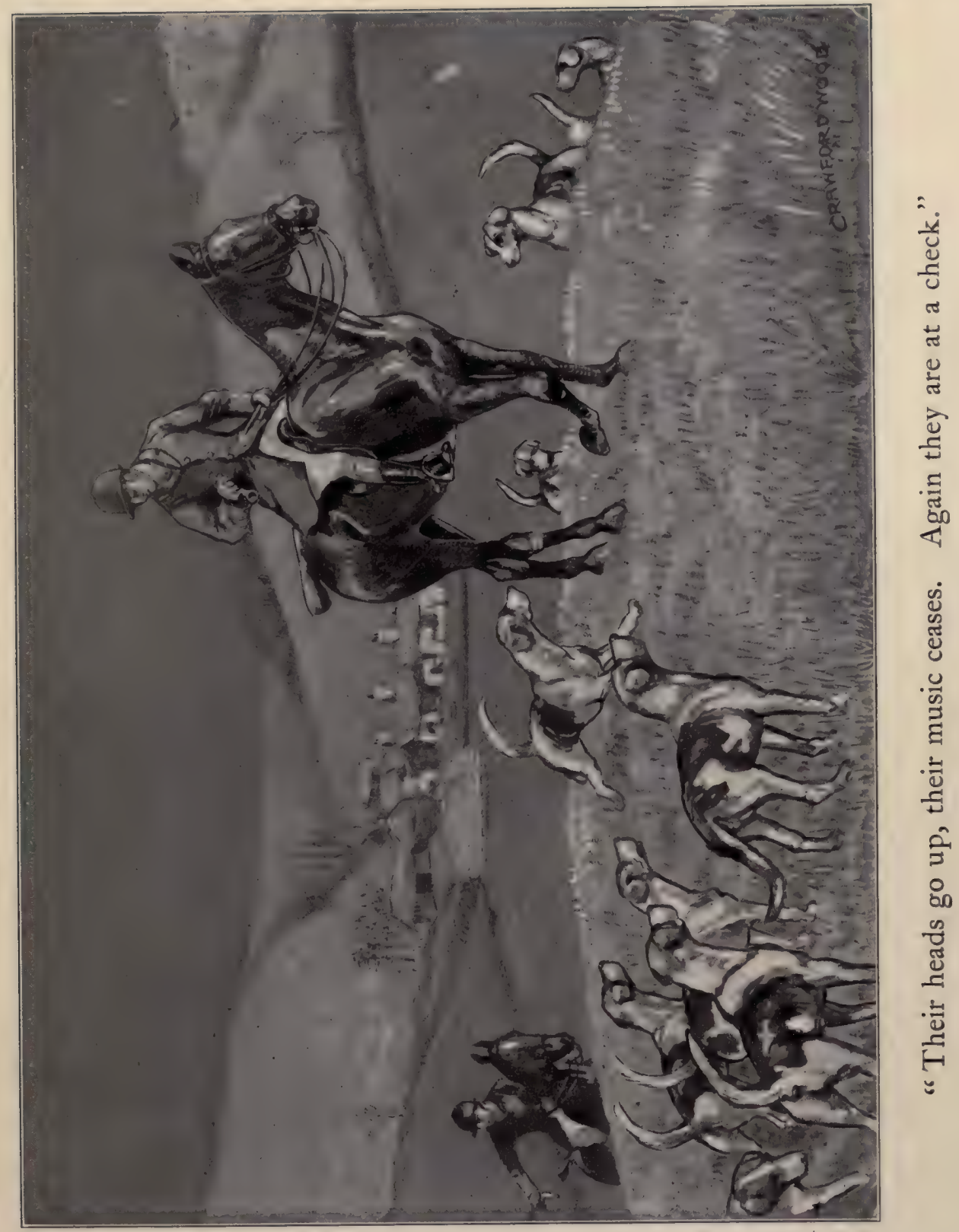



Now he runs through a field where cattle or sheep are feeding, to destroy his line by entangling it with the scent of the tramping beasts. When a check occurs under such circumstances as this the huntsman is considered justified in lifting his hounds smartly forward. It is only another trial of his judgment. In all the confusion, which way has the fox gone? Thanks to experience and the quick hint of instinct, the huntsman in most cases knows to a certainty. Once more he brings order out of chaos, and hounds are again settled to the line. Now the moves in the game are made more rapidly, and Renard, growing more tired, has less choice where to turn. He takes to water, swimming the brook with the hounds close behind him. Ten minutes more of riding, and then Bluebells, Forrester, Bunco, Tinbush, the oldest and trustiest noses in the pack, who, like the wise old hound in Somerville's Chase, have until now been hanging in the rear, " niggards of their strength," are seen charging to the front with renewed energy. The huntsman knows the end is near. The fox's strength is sinking. The scent grows weaker, and only the older hounds can follow it - eagerly, to be sure, since they know by experience what its weakness portends.

Now, if never before during the game, must the huntsman have his wits about him. More foxes are lost when they are dead tired, especially with a fast pack of hounds, than are captured. At such times Renard makes his last trick move against the hounds under their very noses, and if it were not for the woodcraft of the huntsman would get away nine times in ten. There is another check of all the hounds, save old Bluebells and Forrester. The huntsman plunges ahead, for not an instant is to be lost with 


\section{Cross Country with Horse and Hound}

a sinking fox. He leaves the whippers-in to bring on the pack the best they know how, and rides on madly, cheering to his two faithful hounds. A check again : as they come out of a bit of woodland into more open country, even Bluebells and Forrester can follow no farther. Where is Renard gone? West? No; a man is ploughing over there. East? No; a man and a dog are quietly crossing a field in that direction, or a timber-waggon is passing along the highway. Whatever our huntsman does, he takes in the whole situation at one sweeping glance, and his mind is made up instantly. Ah! He hears a jay-bird making an unusual tumult in yonder piece of wood: his fox is passing near it. Or the crows are seen a quarter of a mile away making a swoop toward the earth : they are mobbing the tired fox. Or, again, in a still more distant field a flock of sheep are standing with heads up and faces all in one direction: Mr. Renard is no doubt just passing there.

So the game goes on, plot against counter-plot, cunning against woodcraft, until the crafty fox wins at last or the hounds have accounted for him by tracking him to earth. It needs little more, certainly, to show the reader how important the huntsman is in the game. What we have seen him do, however, is not the half of what he is expected to do and know. It goes without saying, too, that he must be a very superior horseman and an accomplished rider, and know every nook, corner, ditch, and ravine of every farm for twenty miles around.

The duties of whippers-in are, speaking in a general way, to assist the huntsman in the management of the 
hounds. The special duties of the first whipper-in are hardly less important than those of the huntsman. Indeed, some Masters declare that if they could have but one highclass man with hounds they would prefer that man to be the first whipper-in rather than the huntsman.

The first whipper-in must needs be everywhere, nor spare himself or his mount. He must keep to hounds, and this necessity alone requires him to follow them over almost impossible obstacles. $\mathrm{He}$ is obliged to ride many more miles during a run than any other man in the hunt, and altogether must be a most efficient rider and without fear. His function at the covert-side is to go ahead and station himself in such a position as will enable him to view the fox away. The second whipper-in usually accompanies the huntsman into covert to keep the hounds together, prevent their running riot, and see when the fox finally breaks that they are all brought on to the line. The correcting of hounds falls principally to him, the huntsman himself being a sort of shelter to which a hound turns instantly he is chastised. The second whipper-in must be not only a fearless rider, but a thorough horseman, too, riding always to save his horse.

Another important officer of a hunt is the kennel huntsman, usually the huntsman himself or some one grown old in the service of the hunt. On the kennel huntsman rests a responsibility scarcely less grave than that of the huntsman or the Master. We treat of him here as a distinct and separate officer.

The Master directs the selecting and breeding of hounds, but kennel management depends upon the kennel hunts- 


\section{Cross Country with Horse and Hound}

man's ability to carry out the Master's plans. The feeding of thirty or fifty couples of hounds is no small matter. To keep them all healthy, to doctor the ailing, nurse the invalids, bandage the wounded, care for the bitches in whelp, for the puppies at birth and in the trying age of distemper, requires a man particularly fitted and qualified. There are, further, the conditioning of hounds as the hunting season approaches, special supervision while they are hunting, and the keeping of the peace among them at all times - no light matter.

According to Badminton, in hunting five days in a week, as many packs do in England, seventy-five couples of hounds are required; for four days a week, fifty-two couples; two days a week, twenty-eight couples. The annual consumption of food for seventy-five couples is "forty tons of oatmeal, three tons of dog-biscuits, and a hundred and fifty horses." These figures may go to show further the responsibility of the officer in charge of kennels and their inmates. The right apportionment of food is a delicate business. Overtraining may develope temper and jealousy and other disagreeable traits. Altogether hounds need as much watching and care as a lot of children would. Tinbush and Rollicker hate each other; an old feud exists between them. Tinbush snaps at a puppy, and Rollicker comes in, thinking now is his time to pay off an old grudge. Bradshaw, the peacemaker, attempts to correct them both, and in half a minute a dozen hounds are fighting to the death. These battles are sometimes very desperate, and it takes a courageous man to go among the combatants. More than one kennel huntsman has nearly lost his life in attempting to 
settle these disputes when once the blood of the pack is up.

The earth-stopper is usually some old faithful hunt servant who has seen better days, possibly an assistant about the kennels. In England he is generally a superannuated gamekeeper. He is invariably something of a "character," and knows, or has the air of knowing, more about foxes and their ways and about hunting generally than most of the men who ride to hounds. During the summer months he and his pony tramp the country for miles around. $\mathrm{He}$ knows every earth and every litter of foxes within a radius of twenty miles or more of the kennels, and will tell you which farmers preserve the litters and which trap them.

When, on the evening before a meet, the huntsman and the Master have held a council of war and decided on what particular covert they will draw, the earth-stopper is instructed accordingly; and soon after midnight, when the foxes are prowling about in search of food, he mounts his pony, and, with a lantern on his arm and a shovel in his hand or slung on his back, goes the rounds of all the earths in the neighbourhood of the covert proposed to be drawn on the morrow. Arriving at an earth, he collects, or has collected on the way, a bundle of sticks two feet or more in length. These he binds together with a withe, and crowds them into the earth, usually throwing upon them a light covering of loam, his task sometimes requiring half the night and a ride of twenty-five or thirty miles. After the hunt he goes out and unstops them again, unless for some reason it is thought best to keep them closed. 


\section{Cross Country with Horse and Hound}

These nocturnal reconnoitrings of an old earth-stopper are the cause of his reflective turn of mind, probably, and help to fill his brain with the lore and opinions that make him so interesting a person, in winter nights or other leisure times, with whom to talk it all over. 
XXV

\section{HORSE COMPANIONSHIP}


"A nature so noble, so generous and kind, Can only be meant for a man with a mind; A nature like this is intended to blend With minds that are high, and be counted a friend." 


\section{XXV}

\section{HORSE COMPANIONSHIP}
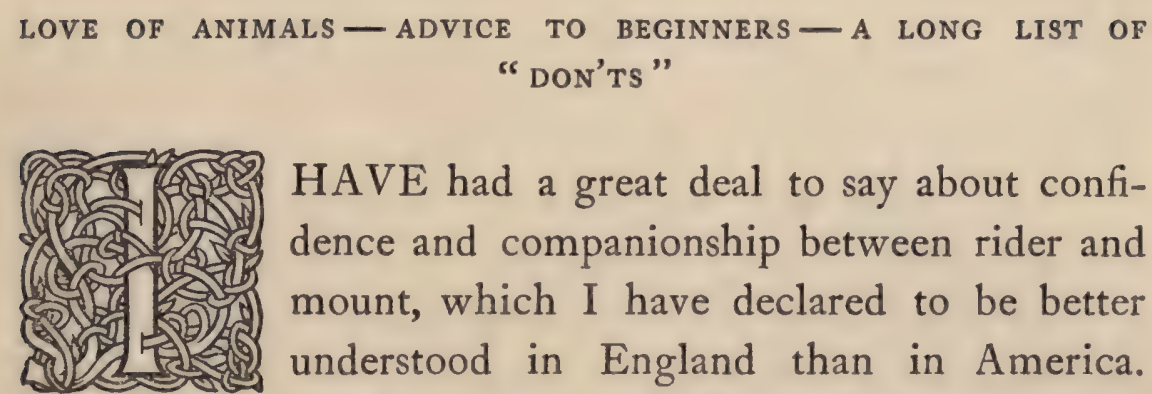

HAVE had a great deal to say about confidence and companionship between rider and mount, which I have declared to be better understood in England than in America. The average American seems to look upon a horse as simply a convenience, like the bicycle or the trolley cars, a means by which he may reach his destination sooner and with less fatigue than by walking. He presses a button and the horse is brought to the door, and when he is through with him a groom takes him away again. The horse does not attain to the confidence of his master as he does in England, where he becomes part of the family. There is nothing degrading in the idea of companionship with a horse. When one comes to think of it, many men and some women not infrequently have about them less edifying associates of their own kind. No man, woman, or child was ever the worse for an intimate association with a well-bred horse or dog.

It cannot be too much insisted on that this companion- 


\section{Cross Country with Horse and Hound}

ship between horse and rider is the very essence of crosscountry riding. Whoever has failed to secure the confidence of his mount and his mount's in himself has failed of enjoying the best half of the game. The right sort of man, even if he may hardly be feeling well enough for a day's hunting, will go out rather than deprive his horse of the pleasure - a bit of self-sacrifice which sometimes happens in England, unusual as it may be on the other side of the Atlantic. The love of animals, especially of horses, is born and bred in the English people. Unlike some Americans, they one and all care enough for a horse that has given them a most glorious day's sport to stay at the stable and see him done up properly and fed before they dine themselves. In England the children are brought up from infancy to consider the feelings of all domestic animals. An old favourite mare soon to have a foal is talked over again and again, and the expectant mother has the best of care. Love and respect increase as the eventful time approaches. She is turned out on the lawn in front of the house, where the grasses are tenderest and sweetest, and the best of everything is none too good for her. The children divide with her their candy; the baby is held up and taught to caress and love her. The dear old mare's matronly appearance is never a cause of shame, but of pride, and when at last she has produced her foal, the entire family, down to nurse and the baby, must all go down to the stable to see it. With such instincts, is it any wonder that Englishmen and Englishwomen love a horse? Is it any wonder that there exists between an English rider and his mount a potent feeling of companionship? Is it any cause 


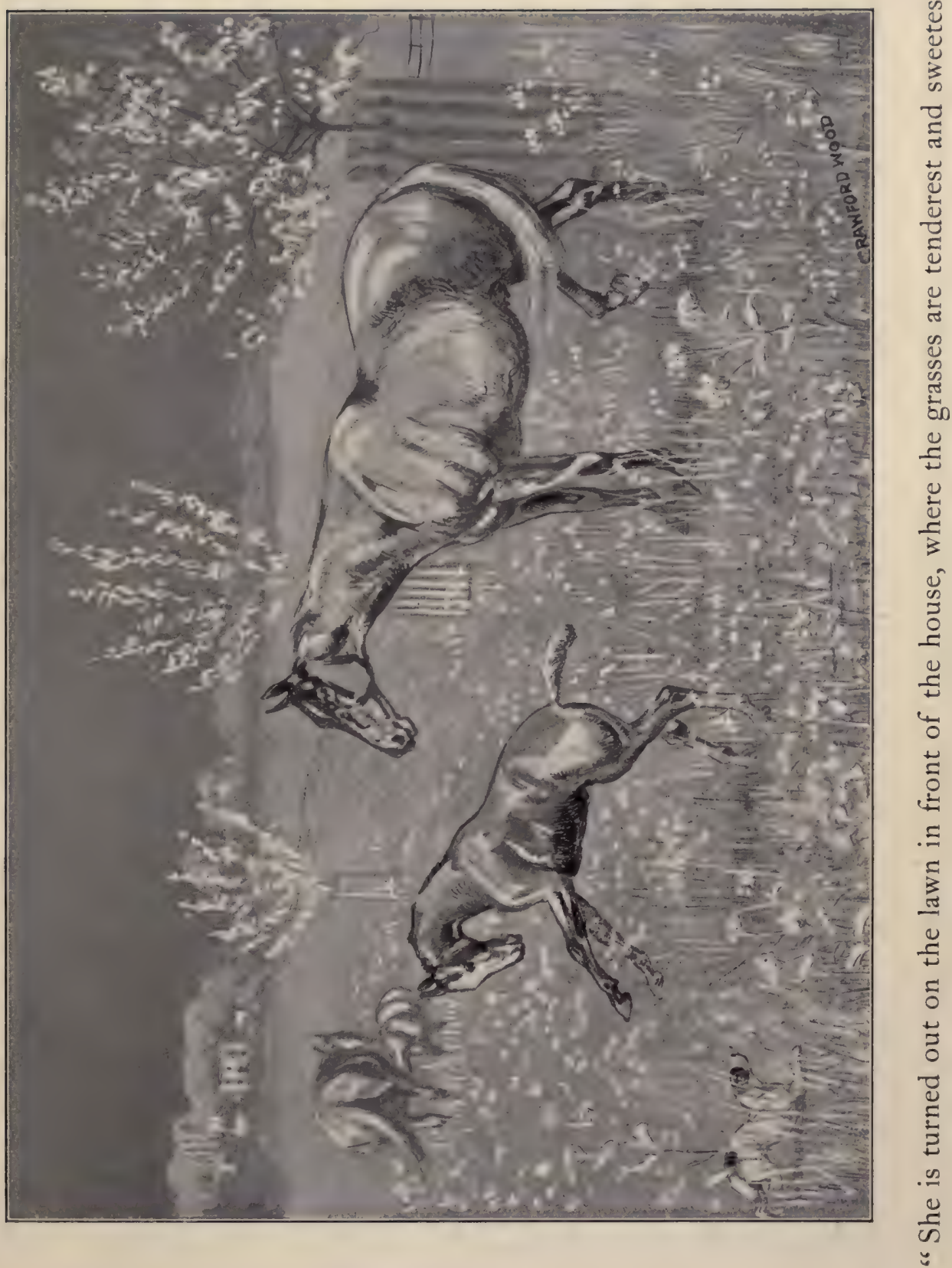





\section{Horse Companionship}

for question why in England and Scotland there are a hundred and thirty-eight packs of hounds? Need one long inquire why this sport has such a powerful hold that it is followed unceasingly through youth, manhood, and old age ?

I recur to this favourite text by way, in this chapter, of advice to beginners and a little confidential talk with the novice reader. Suppose he is to ride to hounds to-morrow for the first time; there will be some things he ought to do, and more that he ought not. Some of the things I have reminded him of already in a general way are considered of sufficient importance to be repeated here. The chapter by no means comprises the whole list of things he ought or ought not to do, but only the mistakes a beginner is most likely to fall into.

Of course he will dress well. An affected disregard for dress on such occasions is even more vulgar than foppishness. If he must wear spurs, let him use them only in case of emergency. The better a man's horsemanship, the less use he has for spurs. If his experience is mine he will find his horse going much better, jumping much more collectedly, more intelligently, and with less fatigue if spurs never touch him, especially at a jump. Also I should say to him, don't wear a new pair of gloves, and don't carry a new hunting-crop. The former is uncomfortable, and, with the latter, makes one look too specially "gotten up." His dress, however neat or expensive, should have the stamp of utility.

Don't ask the Master, the huntsman, or the whippers-in, at the meet, what covert they are going to draw. They never 


\section{Cross Country with Horse and Hound}

like to be questioned on this subject or any other pertaining to the hunt.

Don't ride through any coverts or fields at all in going to the meet. A day's sport may be spoiled by setting the foxes on foot in the very wood the Master intends to have drawn.

Don't call a hound a dog. There could hardly be a worse offence in the opinion of the Master or huntsman. "What a pretty lot of dogs!" said a novice from Boston to our Master, one day at the meet. "They are"-looking them over critically - " the best lot I have ever seen together; ought to send them to the Show."

"What dogs do you refer to?" asked the Master, who was at the moment standing by his mount, with twentyodd couple of his best hounds about him, preparatory to going to covert.

"Why, these dogs; the ones you chase the fox with."

"Oh, you mean the hounds," replied the M.F.H., with a coldness that would have frozen ice-cream, and with a strong emphasis on the word hounds. "Hounds hunt the fox. The chasing is done by the riders." Most masters are very touchy on this point.

Neither speak of a hound as being pretty. $\mathrm{He}$ is beautiful, if you like, but only ladies are permitted to call him pretty - and such ladies only as can lay claim to that distinction themselves.

Don't ride near the hounds. Shun them when you are on horseback as you would Satan himself. If they overtake you riding to covert, go quickly to one side and let them pass. Remember that this is the greatest offence a 


\section{Horse Companionship}

rider to hounds can commit. I have heard such offenders given the severest verbal drubbings I ever listened to. I remember hearing a perfect climax of rage and fury in this respect once at a meet in England, when one of these jealous hard-riding scoundrels actually ran his horse into a hound at the covert-side. The Master jumped off his horse. He could evidently deliver himself better standing. "Take yourself out of the hunt!" he cried. "You did this same thing once before. I ought to throw you into the river. Hounds running? You are a liar, sir!" (The fox had been viewed away, but hounds were not yet on the line.) "You fool! You don't know enough to be out hunting. You don't know enough to know when hounds are running. Pay for the hound? You insulting puppy, you have n't money enough to compensate for the injury to that poor hound." (Two men were carrying the howling hound to a friend's carriage.) "Get out of my sight, you miserable good-for-nothing, and all your kind. Go hire a race-track and ride your fill. You don't know the A B C of hunting, and you never will. Leave my sight and this field instantly, sir, or the hounds go straight back to kennels. This is your second offence, sir, inside of a fortnight. You can't hold your horse? Then shoot him, sir! Such brutes ought never to be permitted to come hunting. Any one but a fool would have had sense enough to know it. Go home and shoot him. And then shoot yourself rather than again be seen in a hunting-field. You are disgraced for life. You and all your kind are the curse of hunting. You kill sport. You know neither how to hunt nor how to ride." - It was quite the worst talk- 


\section{Cross Country with Horse and Hound}

ing to a man ever got, but the Master was perfectly justified. There were probably a dozen more " threshing scoundrels" who were getting the lecture second-hand. A story is told of an M.F.H. who used to ask his second whipper-in to ride up close to some rider who had offended against this " holy law," whereupon the Master would give the whipper-in a stiff scolding for having done what the rider could not then fail to see he had done himself. When a man rides near hounds he runs them "off their noses." They are looking behind to keep out of his way.

The value of hounds in the eyes of the Master and huntsman cannot be estimated in dollars and cents. The loss of a hound in this way is most discouraging to a Master who, as is often the case, owns the hounds and feeds and cares for them at his own expense. The expenses of a first-class hunt establishment in England amount to something like two thousand dollars a hunt week.* Picture, then, the feelings of an M.F.H. who sees a thoughtless, heedless rider spoiling sport. Is it any wonder he loses patience and his temper as well? The one great drawback to hunting, the one thing above all others that gives the Master annoyance, is the jealous riding man. Men who are out to cut down the field are the principal offenders in this respect.

Don't ride up to the huntsman or whippers-in on the way to covert unless you are asked. Keep away.

Don't call the whipper-in a whip. It is as bad as to call Mr. Soper Soap. -

* The Master of the Grafton hounds receives in subscriptions $\mathcal{E}^{8000 \text {, and has to }}$ add to this sum out of his own pocket $£ 3000$ annually to make up the deficit. 


\section{Horse Companionship}

"Hello, Whip; where are you bound for?" No answer. “I say, Whip, where are you going next?" “I beg pardon, sir; I thought you were addressing your remarks to your hunting-crop," comes the reply at last.

Don't ask questions as to what is to be done next. You are out not to chase a ball across a field, but to hunt. It is passing strange that some men never see the thing in this light. It is as rude to ask a huntsman what he is going to do next as it would be to lean over the shoulder of a professional chess-player and ask him what move he is going to make next. The probabilities are the huntsman does not know himself; if he did, he would not be hesitating. He may be waiting for some hounds that are left in covert, and if he should answer the question he might be asked next how it happened the hounds were left. How many times has one seen a huntsman move out of a rider's way whom he saw approaching with questions in his eye! "Won't you have a cigar, huntsman?" said a novice once in my hearing. The huntsman of course does n't like to be rude, but such a thing can annoy him wonderfully. Fancy a huntsman smoking a cigar while hunting a fox!

Don't take any man who is out for the ride for your pilot, nor the huntsman nor whippers-in. The first sees little and cares less for the hunting, being there only to outride some other hard rider; and the huntsman or whippers-in would be seriously annoyed. Let the pack be your pilot; keep the hounds in sight. If they turn right or left you are in the best possible position to cut corners, fences permitting. You will see everything and be in at the death with a single horse, while the hard-riding men 


\section{Cross Country with Horse and Hound}

have seen little or nothing of the game and have done their second horse to a turn.

Ride always to save your horse. That is horsemanship. It is far more to your credit to come in to the death with a comparatively fresh horse, having ridden the line, than to do the first flight or steeplechase act. Riding a steeplechase between the fags is one thing. Fox-hunting is another thing altogether. If you have no interest in anything but the galloping part of the game, join a drag-hunt or hire a race-course and have done with it. You can hardly please the Master or huntsman more than to keep out of the game altogether. You might as well, in playing base-ball, take no interest in the game apart from racing the other fellows round the bases for the home plate. The principle would be precisely the same.

Don't take it upon yourself to advise a huntsman, even if you feel sure he is going wrong. Let him manage the hounds to suit himself. When the game is over, look him up and ask him why he drew one covert up-wind and the next one down, or any other question you like. You will be surprised at his wonderful fund of woodcraft, and will find that he is as ready to talk to you now as you are to listen. You will probably see that had he done what you thought he ought to have done, he would have lost his fox. He generally knows all that you do and a great deal more. Never presume to advise in the field; even the Master of Hounds himself never meddles with the game after hounds throw off. "I think the huntsman is wrong this time," you may say to the Master. "I think so myself," says the Master, "but he is hunting the hounds, and we 
must let him and the hounds cipher it out in their own way."

Don't lark your horse over fences in the presence of the hunting-field. It is the work of a horse-dealer, or a very swell-headed rider who wishes to display himself.

Don't ride about on a steaming horse anywhere near hounds when at a check. The perspiring horse will foil the line for rods about. Jump off, if only for a minute, and rest your horse. Think how it would be with yourself, carrying even a very light parcel, if you could not change it to the other hand or set it down a moment. It may seem strange to some of my readers that I should mention so evident a fact, but city men as a rule are great offenders in just these nice points of horsemanship.

Don't allow your horse to. rush his fences if it is within your power to control him. If you cannot hold him, sell him, or send him to the plough. Such a horse has no business in the hunting-field. It is a sure sign of funk in yourself or your horse, or both. Perhaps he is not properly ridden, as I suggested before, and his rushing comes from the punishment you give him by pulling at his mouth or spurring him at every jump. In any case, it is probably the rider's fault.

Don't follow some daredevil rider over barbed-wire fences or any other unreasonable obstacles. He has done it to show off. Either his hunting-flask put him up to it, or he is one of those empty-headed fellows who court admiration. It is as vulgar as it is unhorsemanlike. You had better be called a coward by all such fellows than an "empty-headed ass" by the Master. I have said so much 


\section{Gross Country with Horse and Hound}

about giving your horse his head at his jumps that I need only remind you here that it is the highest accomplishment in the art of cross-country riding to have so perfect a seat that you can give your horse freedom of his head at his jumps. Don't be discouraged. Keep at it, and ever at it, until you succeed. No man can ever hope to become thoroughly proficient in cross-country riding until he can ride a horse over jumps entirely independent of the bridle-reins. If you forget everything else this book contains, remember this.

Don't forget to bring your best manners with you into the hunting-field. No matter what your station in life may be, when you are playing the game put yourself on a level with the humblest member. Among sportsmen play a sportsman's game. Snobbishness in the hunting-field is disgusting.

Don't neglect to say a kind word to the farmers. Take off your hat to any man in the game who shows a better seat, better hands, or better horsemanship than your own. You need not be surprised to find such a man riding in a rusty coat, a sportsman indeed, and your superior at the game. If you are a true sportsman too, you will be the first to acknowledge his superiority. Let not the novice follow the snob's too common example in the huntingfield. After once visiting a neighbouring hunt club he should desire to be thoroughly welcomed by every member when he comes again.

Don't be seen pulling at your flask : it causes uncomplimentary remarks, especially if you get a fall afterward.

Don't offer it to a brother sportsman; it may mean a 
drop too much. Jumping-powder makes the reckless foolhardy. The worst accident I ever saw in the huntingfield was the result of one flask rider daring a rider with an empty flask to jump a picket fence on the road home after a severe run to hounds. "Good! I'll go you for a fiver. Go ahead." Over went the leader, his mount rapping the fence heavily with every leg. After him went Empty-flask, against every one's remonstrance, setting both rowels into his horse's sides as he reached the fence. We held our breath till he should be over. But no! Empty-flask's stimulus had done its work, and its effects were on the wane. With a sluggish swerve of the body forward and a violent pull at the bridle-reins to regain his position, the wicked spurs fairly doubled and shut his horse up instead of extending him. Smash! went the fence, the horse taking it breast-high. Smash! went Empty-flask headlong to the ground in a soggy, senseless heap, and there lay till his mount turned a complete somersault upon him, and began threshing wildly with his legs, the unconscious rider's spurs digging into him at every move.

"The spurs did it," said one.

"His horse was done," said another. "Reaction against too much stimulants," was what they thought.

"I 'll never offer a flask to a man in the hunting-field again as long as I live," said the fallen rider's friend.

"You don't mean to say he was drunk?"

"No; only the stimulant had shot its bolt. It was a broken leg for a drop too much." -

Don't scold a groom in the presence of a third person. Don't lose your temper with any horse, no matter what 


\section{Cross Country with Horse and Hound}

he does. If he gets out of patience, it is nine to one the fault is with yourself. If he does n't know how, send him to school. If he can't or won't learn, send him to the plough.

Don't take the least advantage of your mount. There must never be any question of your right to govern, but the man that governs least is best obeyed.

Don't ask a horse to do fractions until he can add and subtract.

Don't mount any horse, for any purpose, until you have examined the set of his bridle and bits. Grooms are careless about not altering bridles to fit different horses. See that the snaffle is just low enough not to wrinkle the lips, and that the curb hangs easily and naturally below it. Look to the curb-chain and keep it well let out. Nine grooms out of ten get it too short. Look to the throatlatch; let it out so that there is no question of its not being perfectly loose; and treat the nose-band in the same way. These are little things, but they annoy a sensitive high-bred horse and make him irritable and cross with you. It is too bad to spoil a good day's sport for a good man and a good horse simply because the bridle does n't fit. With a cold-blooded draught-horse it may make little difference, but a high-bred horse, especially if he is a little over-fit, is as sensitive as a baby to pain or discomfort. You would not be comfortable yourself with a collar-button rasping your neck.

Don't have your girths too tight at first. This is another point where grooms are commonly at fault. A tight girth irritates some horses, and you upset their tempers and get 


\section{Horse Companionship}

into a fight with them before you are fairly started. If the horse is light-waisted, ride him with a hunting breaststrap. When you reach the covert-side, take your girths up a hole, if necessary, while sitting in the saddle.* If your mount has the proper conformation you need have little fear of a saddle turning.

Don't choke yourself with a stock, a tight-fitting coat or boots. These things make the man cross, and the horse generally has to suffer for it.

Don't neglect to give your stirrup-leathers a good twisting before you mount, so that the stirrup, when in position, instead of hanging flat against the horse's side, hangs at right angles to it, with a straight opening for your foot. It looks better, feels and is better. (See page 109.)

Don't ride in a knee-padded saddle, or one with a flask- or sandwich-case fastened to it. They are more or less in the way, and the pad and flask prevent an easy return to your seat if you are thrown on to your horse's neck. The flapping sandwich-case also cannot but be a source of annoyance to the horse.

Don't buy a thick padded saddle that sits high up on your horse. Get one as thin as possible, and stuffed with real hair. The nearer you can get your seat to the horse, the better. You will be surprised, if you have always ridden on a thick saddle, to note how much easier you ride on a thin one, especially if you ride by balance. There should be little or no padding whatever under the flaps of the saddle; a thick piece of pigskin under the girth-buckles is quite sufficient. Half or three quarters of an inch makes a wonderful difference. 


\section{Cross Country with Horse and Hound}

We have left one of the most important "don'ts" to the last: Don't ride a horse a rod with a perfectly slack rein, no matter if you are tired and the horse is too. This is a very common error. Instead keep always a light touch on his mouth. In this way, after you have ridden even a tough-mouthed horse at a walk as well as at a trot, you will be surprised to note that he will soon begin to answer to a very light pull, and finally that an almost imperceptible touch of the reins will guide him. Horses get the notion, if you ride them with a slack rein at a walk or slow trot and take them by the head when going fast, that the slack rein means to go slow and the pull back to go aheadjust the contrary of what you really intend. This style of riding is of course, therefore, the best way to turn horses into pullers, and is one of the worst habits a rider can get into. For the same reason don't let your hands drop stationary in your lap. Give your wrists perfect freedom to enable you to keep a uniform touch, which, of all things, a horse seems to prefer you to do. If you have been in the habit of riding with your hands rigid you will be surprised to notice what a give and take your hands must make to follow the natural oscillation of a horse's head. Nothing you can do will improve your own hands more than to ride horses when at walk, and at all times, for that matter, in this style. Practise on the way to the meet and covert, especially when walking a horse; try with the least amount of effort possible to make him cross to the other side of the road and back, or move from the road to a side-path. You will find in time you have made a most 


\section{Horse Companionship $29 \mathrm{I}$}

wonderful change both in the horse's mouth and in your hands.

Any one of these " don'ts," taken separately, sounds insignificant; but the neglect of them in the aggregate ruins a horse. Attention to these little things makes the finished rider. 


\section{XXVI}

\section{THE CONSULTATION OF WAR}


"s And now, brother sportsman, go home to your rest, And dream of the chase till the morn; Ride on in your sleep o'er the fields of the west, The vale that puts rider and horse to the test, And follow the hound and the horn." POEMS IN PINK 


\section{XXVI \\ THE CONSULTATION OF WAR}

ARRANGING FOR A DAY'S HUNTING-AN ELABORATE PREPARATION - OLD SIMPSON AT WORK

"UNTING," says the immortal Jorocks, “is
the image of war without its guilt." Few neglect of which would soon bring the hunt to the end of its popularity. The idea that a fox-chase consists simply in the coming together of a lot of riders who go to a covert, start a fox, and race him to death, is one that any real acquaintance with the sport speedily dispels. I have attempted, perhaps with some success, to show what is involved in the establishment and maintenance of a wellorganised hunt. I come now to the preparation for a day's sport, in which the general and his aide lay plans and plots for the ensuing engagements.

It is the evening before the day of a meet. Weeks earlier it has been determined where the meets shall be for the month, and printed notices to that effect have been sent to all the members and farmers and patrons in the county. The Hall, where the Master resides, is of course filled with guests, 


\section{Cross Country with Horse and Hound}

themselves full of merriment and expectation. After dinner the Master excuses himself, and is soon closeted with the huntsman, who has come in to discuss plans for the morrow. The county map is taken down, and also a map which the Master has had specially made, on which is marked every farm, lane, woodland, ravine, or brook in the neighbourhood. With these spread before them, and the Master's note-book at hand for reference, the two proceed to work. The note-book is a complete chronicle of past events, giving a history of every run, and a record of the participants in it, and of every covert drawn for years past - a regular log-book, in fact, and most indispensable it is, too. The Master opens the consultation.

"Well, Huntsman," he says, "what do you think of drawing the Maple Ravine? Or shall we try the Peters gully? We had a capital run from there last year."

"Please yourself," replies the huntsman, who has reasons of his own for not drawing either place, but is politic enough not to advance his own preferences. He will let the Master draw these out of him to suit himself.

"On some accounts," says the Master, "I prefer the Springer woods to either. You see, we shall have some followers out with us to-morrow from the Blanck Hunt, and they 're said to be devils to ride. I should like to give them a ride across some of our great grass meadows. We might draw the woods behind Parker's. Or what about Johnston's ravine, with a chance of a run over Burden Flats?"

"The flats have been planted with beans this year," says the huntsman, "and the recent rains will make the going awfully slow." 


\section{The Consultation of War}

"It would serve some of those jealous riders right if they had to go slow for once," comments the Master; "only they would kill their poor horses."

"How about the ridge road at Fur Forks?" asks the huntsman, now coming forward with his own plans. "Old Simpson " - our old friend the earth-stopper - " says there are two litters of foxes up there, and the farmers are anxious for you to give them a dusting."

"That 's a fact," agrees the Master. "We ought to go there. Mrs. Jenks wrote me yesterday that she had lost some of her chickens. They were struck by lightning, most likely. Foxes don't kill chickens, you know; at least, not in their own neighbourhood."

"The going will be good up there on the high ground," suggests the huntsman, who probably has seen the farmer and knows that the litter has been carefully preserved for the hunting season.

"That 's a fact," says the Master. "The trouble is, Mrs. Whirler is coming out to-morrow with a four-in-hand and a party of friends. She and a dozen more have written to say they are bringing friends, and hope they will be able to see some of the run from the highway. The ridge is altogether too rough for four-in-hands, or for any other kind of driving, for that matter."

So every covert for three miles about the place of meeting is gone over, pros and cons carefully compared. Finally it is decided to draw the Benson Wood, and, failing that, the Peler ravine. By this time, thinks the Master, the coaches will have turned back, and, if there is still time, the hounds may be taken to the ridge road. 


\section{Cross Country with Horse and Hound}

After this much of the programme has been decided upon, the best ways of drawing each covert are discussed. The Master next goes over his list of hounds, making selections with a view to uniformity of size especially, for he wishes to display his beauties to the best possible advantage before the visitors next day. Then they decide which horse the Master shall ride, and which for his second mount. The huntsman also makes his selection, and decides upon the mounts for the whippers-in. There are, further, three or four mounts to be provided for guests - ladies, perhaps, as well as men. These selections must be carefully based on what the Master knows of the riding of each guest. All this takes time, the list being changed and changed again. In addition, two or three carriages are to be provided for ladies and guests who do not ride, together with the incidental question of who is to drive them.

Already the consultation has consumed an hour or possibly two, and the business is only begun. The huntsman has yet to go to the kennels, and wake up old Simpson the earth-stopper, and explain the programme to him; and to see the kennel huntsman and give him the list of hounds that are to go out to-morrow. This must be known the night before, so that their next morning's feeding may be regulated accordingly, either very light or none at all, depending on the time of the meet and the distance from the meet to the covert. From the kennels the huntsman must turn to the stables, and go carefully over the programme of horses with the head coachman. The whole train must be carefully laid.

By the time the Master and his guests are saying their 


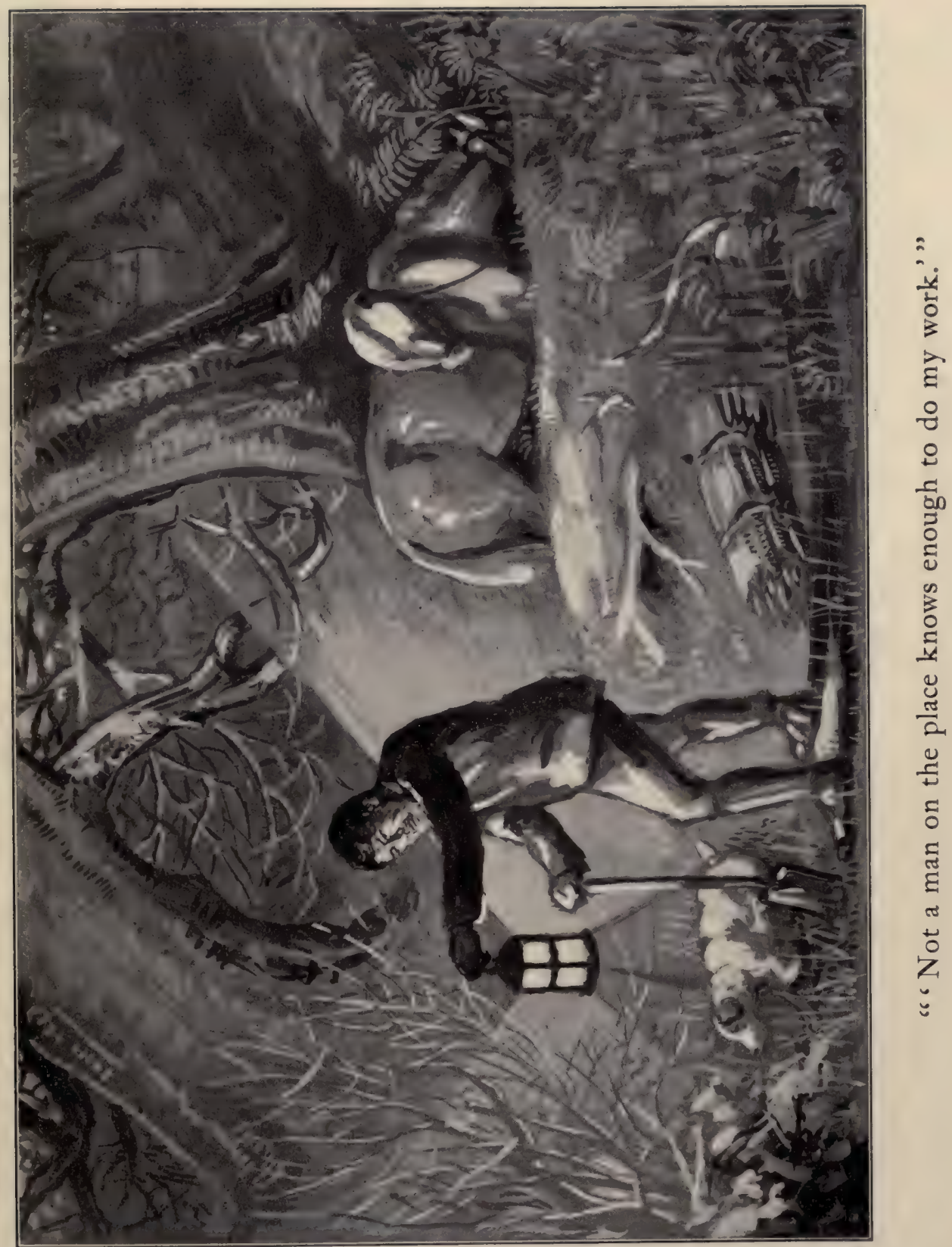





\section{The Consultation of War}

good nights, old Simpson the earth-stopper, last but not least, is saddling his pony, and before they are asleep is grumbling to himself along the highway, his lantern on his arm and shovel strapped to his back, while his faithful little terrier Skip trots along behind him for company. "Why do they want to draw the Benson Wood and then go 'way off to the ridge road?" he grumbles. "Just to make me as much work as they possibly can, I suppose. And after it is all done they may never go nigh the ridge. Foxhunting ain't what it used to be when I was a boy."

So he goes along, scolding to himself. Sometimes he tells his troubles to the pony and Skip, who, though they may both sympathise with him, are powerless to change the general's commands. "I have a mind not to go a step," he says to the pony.

Yet if you should meet him two hours later, going along some dreary bye-road in the dark windy night, and say, " Hello, Simpson; is n't this rather rough on a man of your age?" he would not agree at all.

"Oh, nonsense!" he would retort. "I could give any of the boys a hard day yet if they tried to follow me"; and then he begins to tell some appallingly long story about his prowess at the battle of Gettysburg. Or if you should say, meeting him some cold, rainy night crossing your farm on his white pony like a ghost, “Well, uncle, have n't they some younger man to do this work?"

"Not a man on the place knows enough to do my work," would be the quick reply.

To hear him grumble and growl before he gets under way, you might suppose him the most abused man on the 


\section{Cross Country with Horse and Hound}

place; but if you should utter one protesting word against the Master you would think the old man again in the battle of Gettysburg, in the thickest of the fight, so hot would be his defence. Good old Simpson! When he dies every true sportsman will mourn his loss. 
XXVII

THE MEET 
"What a fine hunting day! as balmy as May, And the hounds to the village will come.

Every friend will be there, and all trouble and care Will be left behind them at home.

"See the servants and steeds on the way, And sportsmen their scarlet display.

Let us join the glad throng that goes marching along, And we all will go hunting to-day."

HUNTING SONG 


\section{XXVII}

\section{THE MEET}

THE M.F.H. AS HOST - IN DISCHARGE OF HIS SOCIAL DUTIESINTRODUCING A FEW FRIENDS

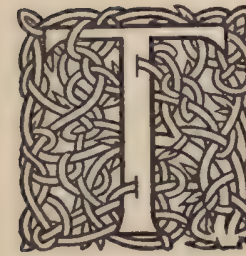

HE meet to-day is at, say, the Master's house; time, half-past ten; the hour for going to covert, eleven.

During the preliminary minutes the guests saunter about the grounds or visit the stables to look to the condition of their mounts. The great dining-hall is open to all who come, its hospitable board laden with choice joints of cold meats, salads, and fruits, and decorated with rare plants and flowers. The sideboard is a forest of bottles; beer, wine, champagne, sodas, or milk are there for one's choice.

Before long the members begin to arrive, leaving their horses in the first empty stall or box they come to, from which the Master has had his own horses removed to make room for them. You may see their riders presently going in couples across the beautiful lawn toward the house to pay their respects to the Master, and have, as the Scotch say, "a wee nip" before going to covert. Soon a steady procession of carriages and pedestrians is moving up the drives 


\section{Cross Country with Horse and Hound}

and walks. Lest any of the country members perhaps hesitate to enter the house, either the Master himself, or a friend or guest assigned to the duty, goes about among them, making hospitably sure that no shy stranger goes away unbidden. Mrs. Whirler drives up with her coach and four, loaded to its utmost capacity with visiting friends. $\mathrm{Mr}$. $\mathrm{H}-$ comes surging around the curve of the drive with a six-in-hand to his old mail-coach, at the same time that a sporty young man lands a smart tandem across the green. It is all a most engaging medley - four-in-hands and farm-waggons, tandems and butchers' carts, spider phaëtons and buckboards, friends, neighbours, tenant-farmers, visitors, villagers, and a dozen families or more, with their guests, who have moved into the valley for the hunting season.

Having welcomed the guests who have come to the house, the Master, some little time before eleven, hurries out for a word with any who are unable or disinclined to leave their mounts or carriages. The first one to greet him is Daisy Mulford, mounted on her half-bred pony. Miss Daisy lives some seven miles away.

"Oh, Miss Daisy," says the Master, affably, "pleased to see you out to-day! How are your father and mother? Your old pony looks keen as ever."

Daisy, who has been going over and over again in her mind just how she shall say something she has meant to say, summons up her courage, as the Master is about to pass on, and ventures a query.

"When are you going to have a meet at our farm?" she asks.

"Well, I hardly know. Are there any foxes down there? We have had some capital runs from your place." 


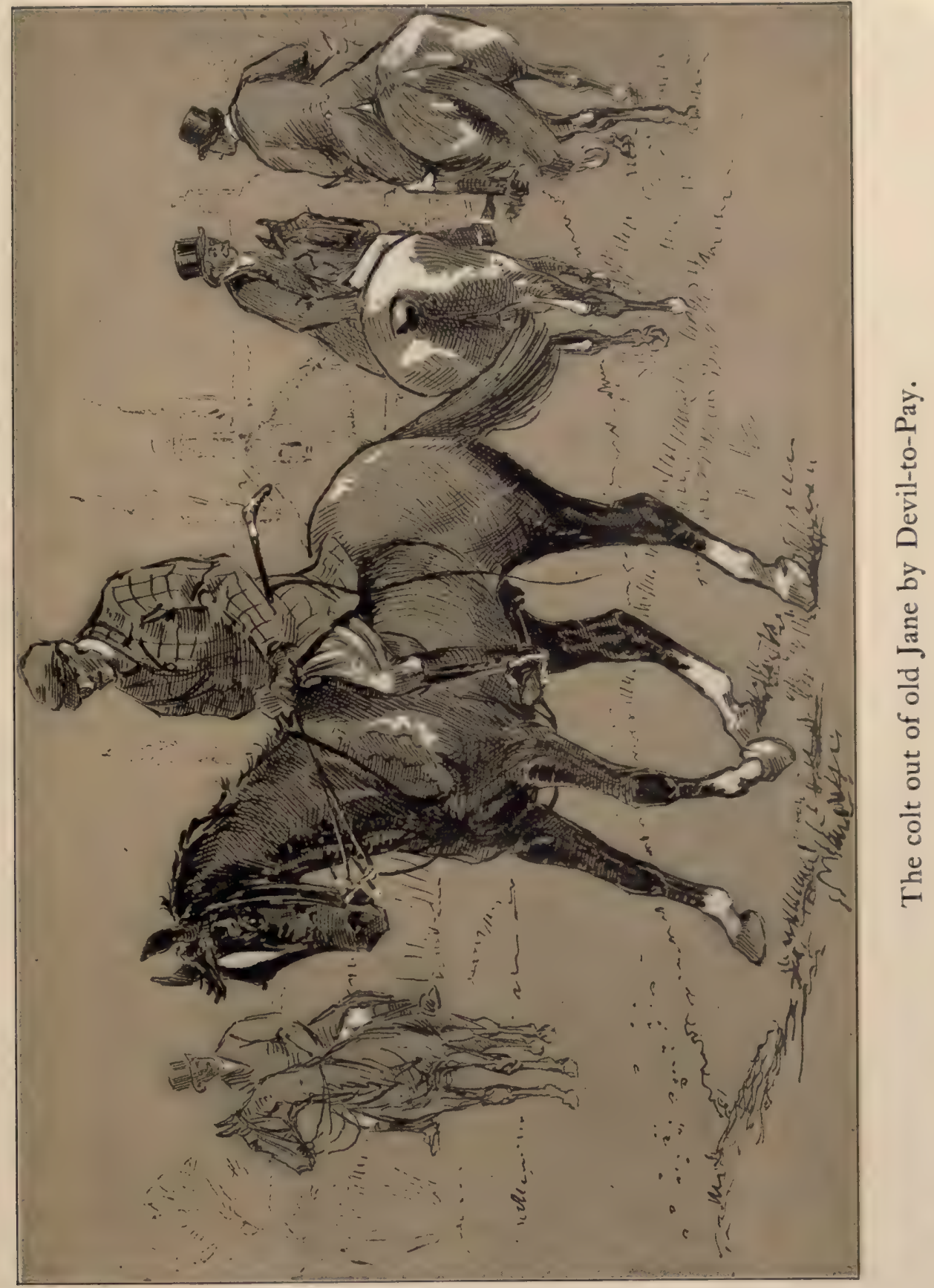


"Yes," answers Daisy; "Mamma says she thinks there are, because our hens have been going lately." Then, for fear the Master may think perhaps she is hinting for compensation, she hastens to add: "We 're not sure that any fox has taken them. Papa says it 's probably a skunk, or perhaps the Italians working in the gravel-pit near our farm."

"Give my compliments to your father and mother, Miss Daisy," says the Master. "I will send the huntsman over there to look into the matter. Meantime you might ride your pony about the coverts and see if you can locate an open earth. If you can't we shall have to turn the pack on the Italians. You shall be my whipper-in or the huntsman, whichever you prefer!" - with which the Master lifts his hat and passes on. Mrs. W- with her four-inhand enjoys not even a taste of the pleasure that fills Miss Daisy's heart this day.

"Good morning, William," says the Master, next, to a farmer's son on a long-tailed four-year-old colt. "What's that you are riding to-day, my lad?"

"Oh, that's the colt."

The Master does not seem to understand.

" The colt out of old Jane," adds the boy.

“You don't say so!" The Master looks him hastily over. "Surely he is the right stamp. What was his sire?"

"Why, your thoroughbred stallion Devil-to-Pay."

"Is that a fact? Well, he can't help being the right sort, can he? And he is in good hands, no mistake. You always give him his head at his jumps, don't you, and bring him to his fences well in hand, with his hocks well under 


\section{Cross Country with Horse and Hound}

him? Right, my boy." Then he leans forward and whispers, "Don't you think your curb-chain is rather tight?" And then aloud, "What 's the name of your colt ?"

“Devil-to-Pay Second," comes the quick reply.

The Master turns away laughing. "Smart lad, that," he thinks. "He has the making of a sportsman." And the boy, on his part, has received a valuable lesson in horsemanship. Delivered in a tactful and sportsmanlike manner, it sinks deep into his mind.

Up comes Miss Frances in a two-wheeled pony-trap, a sweet girl of sixteen from Rochester. "Oh, Miss Frances! Delighted! How smart you look in that new hunting-frock! Dear me, you will be breaking the hearts of all my young men. How can they chase foxes when you are in sight?"

“Oh, but you 're a taffy-giver!" laughs Miss Frances.

"That hard-riding boy Arthur, they tell me," continues the Master, imperturbably, "has already cut the other fellows out."

"Now don't you make any mistake, Mr. Master" with a great show of indignation. "He is too shy a rider to catch anything - I mean - "

"What, ho, there!" laughs the Master. "Has his fox slipped covert or have you come to a check? My word for it, Arthur is a fine chap. Give the boy a chance to view you away. The trouble is, the other fellows have foiled your line."

"I should like to beat you!" cries Miss Frances, reddening and shaking her pretty fist with a great exhibition 


\section{The Meet}

of earnestness. What she really means, as one may see by the look of her eyes, is something quite different.

Follow the Master, and you will see him next taking off his cap to an old dame and her two daughters on the back seat of Farmer Sykes's democrat. Farmer Sykes is on the front seat with a couple of sturdy boys, also of the Sykes persuasion.

"Good morning, Mrs. Sykes. And how are you, James? Any foxes up your way?"

"Oh, yes," says Farmer Sykes. "A vixen has laid up her cubs in that old earth in the spring lot by the thornapple tree. They must be very fit, too, I 'm a-thinking, for my misses declares the mother has been feeding on her prize Plymouth Rock pullets all summer. If you don't come up and bustle them about a bit pretty soon, they 'll be so fat they can't run."

"I 'll be up there," says the Master,- -and he makes a memorandum in his note-book, - " and give them such a dusting as a fox never had before in his life. I suppose you 've no objection to our hunting over your farm, Mr. Sykes?"

"Not a bit. Come as often as you like. Kill your fox in the parlour if you want to. A little blood would do the old carpet good. My misses was saying only the other day it was getting awfully faded."

"All right, James; but," with a sly look at the two Miss Sykeses on the back seat, "I think I had better send some of these two-legged hounds to do the hunting in the parlour." And the troubles of the Sykes family - bad crops, an overdue bank-note, the drought, and the grasshoppers 


\section{Cross Country with Horse and Hound}

- are forgotten for the rest of the day, thanks to a pleasant word.

"Who would n't take a puppy," says Mrs. S., "for such a nice gentleman ?"

“Who would n't protect an earth with a litter of foxes for such a man?" says her worthy spouse.

A young man from Boston, the hard-riding lad Arthur, of whom the Master spoke, catches his eye.

"Hello, Arthur; what 's the matter? You look sober. Did the boys do you at cards last night? Why the deuce are you not looking after Miss Frances, you rascal! Last week, if I wanted to find you, I simply had to look for her."

"Oh, pshaw! It 's all up with me," Arthur answers, hardly.

"The deuce it is! I know a thing or two. By the way, I'm asking her mother to bring Frances over to dinner on Wednesday. You are going to be my guest that day."

"But I - "

"Not a word, sir. I 'll entertain mamma, and you shall have everything your own way, old boy! There! Ride to your own line, and don't forget your failings. Hold hard! Hold hard! And may the Lord have mercy on your soul!'

The Master notes that the hour of eleven is at hand, and prepares to mount his faithful old hunter, the Sheik. Just then, however, he spies, standing aloof from the others and half hidden by the great clump of evergreens, looking quite sad and unhappy, a villager who for a good many years has ridden to hounds as often as he can leave his business in town. Gossip says Villager's wife has been flirting with 


\section{The Meet}

a married man from a neighbouring town for several years, and he has had more than one good word of advice and comfort from the Master. Mrs. V. has lately taken her departure from home, and suspicion is great. Only the Master of all those present knows Villager's secret. The two men shake hands.

"Any news, Villager?"

"No," comes the sad reply.

"I am sorry for you!" says the Master, still holding him by the hand. With another warm pressure of the hand, he hurries on.

Villager bites hard against his lip. His face hardens, and he reins his horse farther back into the evergreens, brushing away a tear with the back of his hand.

But by now it is almost eleven, and every one not yet mounted prepares to mount. Toot-toot! goes the horn, and soon a long cavalcade is getting into shape to jog along to covert. 


\section{XXVIII}

RIDING TO COVERT 
"See, the pack are game and sprightly,

Oh, they tread the road so lightly!

O'er each wilful face uplifted

Thoughts of sport have sweetly drifted,

And I hear the rustling music of their feet upon the way."

RHYMES IN RED 


\section{XXVIII}

\section{RIDING TO COVERT}

MOUNTING FOR THE START-A RIDER IN A FIGHT WITH HIS HORSE - MRS. SO-AND-SO AND OUR HUNTSMAN - POSITION

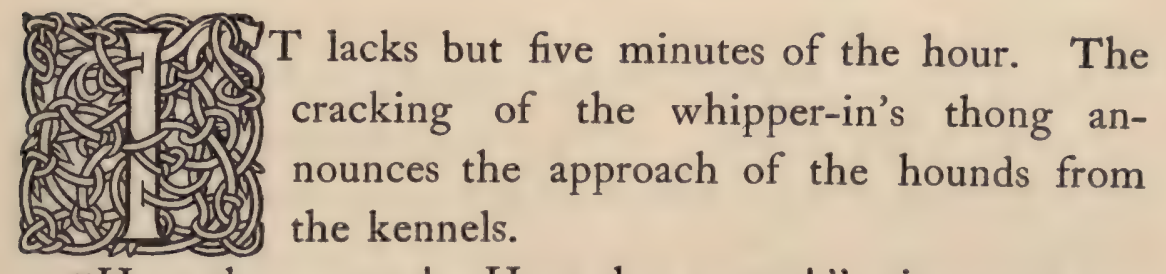

"Here they come! Here they come!" cries every one to his neighbour, and the whole company turn like the minor actors in a play to see the star of the performance making his entrance upon the stage. "Here they come!"

The huntsman, with twenty-odd couples of hounds trotting beside his horse, rounds the bend in the drive, and the admiring crowd stand back to admit them to the lawn. Bowing to right and left, he greets everybody with a face brimful of smiles and cheerfulness. The whippers-in are looking very smart in their velvet caps, hunting-coats, top-boots, and white breeches. Their saddle- and bridleirons are polished to the last degree, and everything about them is scrupulously neat, yet at the same time most businesslike. Their horses, like themselves, are well groomed, and as fit and well-mannered as feeding and train- 


\section{I 4 Cross Country with Horse and Hound}

ing can make them. You can tell with half an eye they are very well bred and very fast. The hounds also, you cannot but notice, in size, colour, and markings show evidence of the carefulness of their selection. Altogether they are the pride and admiration of all the hunt.

When the huntsman comes to a halt the crowd has formed in a wide circle about him. Hunting men and hound-fanciers are already discussing the points of the hounds, and farmers and their wives and children are pointing out what hounds they have had at their own farms at walk, recounting their deviltries with real delight. Occasionally a young hound recognises his country friends, and trots over to them at the sound of their voices or upon hearing them call his name. They may have come miles, some of these people, just to have a word with the puppy they "walked," and to see how he looks as a hound in such grand company.

“Of all things!" cries Mrs. Farmer. "Why, Puppy, how you have changed! When he left our place," she will explain to whoever is standing near, "he was as fat as butter, and now look at him. You can count every rib in his body. Dear me! he must have been homesick. He has more muscle and I dare say he minds better, and all that. But fancy his going out for a hard day's work with no breakfast!"

Villagers old and young fill out the circle, while firsttime visitors to the hunt look on in open-mouthed wonderment.

Meanwhile the hounds are walking about the huntsman's horse, sitting on their haunches, rolling on the grass, 


\section{Riding to Covert}

or lying at full length on the velvety turf. Some of the younger hounds already are trotting about with noses down and sterns waving, not having yet learned to husband their strength.

"Back, Songstress; go back!" A crack of the whipper-in's thong within an inch of her side sends one of these triflers to the ranks with stern down, very crestfallen.

"Do you see that hound by the huntsman's stirrup?" asks a hunting friend of a stranger he has taken in hand. “That 's Bluebells, the Master's favourite. Is n't she great? Her fling and drive in covert are something wonderful. That big upstanding hound is Trumpeter, the bestnosed hound in the pack. When he fails to follow a line no other hound need make the attempt. That black-andtan bitch rolling on the grass is Quickstep - the most musical tongue you ever heard. Her voice is as clear as a bell.",

"What hound is this?" asks a farmer of the huntsman.

“That 's Vagabond, by Vampire out of Quickstep."

"And this one?"

“That 's Barmaid, by Villager out of Bonnie Maid."

“I want to know!" replies Mr. Farmer. "Looks just like her old dad, don't she?"

"Very much indeed," replies the huntsman, who might have added that she also has inherited the vice of her mother in giving tongue only as long as she can lead the pack - a very jealous hound; the moment she drops behind she has no interest in the game.

So the talk and admiring comment run about the circle, while snap shots without number are aimed at the picture.

It lacks two minutes of the hour. Toot-toot! goes 


\section{Cross Country with Horse and Hound}

the huntsman's horn, as a signal to mount. The stable doors are thrown open, and a row of horses that have been saddled and bridled and backed into their stalls are liberated with a rattle and led smartly out upon the lawn. All is bustle and confusion. Village boys and grooms, who have been leading riders' horses aimlessly about, now bring them forward. Riders are hurrying hither and thither across the lawn in search of their mounts.

"What 's become of that blamed boy, I wonder?" queries one nervous man; but no one is there to answer him. Presently, however, the boy is spied, dragging his feet along as if they were lead, and tugging at the bridle of a highly bred horse that seems ashamed of being seen in such uncouth company.

Another rider, in the excitement of the moment, fails to recognise his own horse, which is standing just at his elbow, and he calls like a cow that has lost her first-born among a herd of strange cattle.

"Micawber! I say, Micawber! Where the-"

"Here, sir," says Micawber, giving the rider a touch on the elbow.

"Oh, well, where the deuce have you been keeping yourself all day?" And without even a glance at bridle, throat-latch, or girth, he hurriedly mounts. One might have expected as much. The excited and blustering way in which the gentleman mounts is of itself enough to put the horse on his mettle. The rider is trying vainly to put on his gloves; the horse is eager to go on with the moving hounds; and a fight begins then and there between the two. Which of the two is at fault? It will be interest- 


\section{Riding to Covert}

ing to watch them, for, if we mistake not, there is trouble brewing for both.

The carriages manœuvre to get into line. Expectancy, animation, joy, light every face, excepting only our novice rider, who looks very serious and a trifle bewildered. Fortunately, however, he has mounted in time to avoid a misunderstanding with his horse, though one must confess he went about it in a mechanical sort of way, impelled rather by some force outside of himself than by any obvious free will.

The Master is most punctual; there is no five minutes' grace for late-comers. "Give them five and they will want ten. No, sir ; not a minute," he declares.

The town clock strikes the last stroke of eleven. Again the huntsman's horn is blown. It is the signal to move on to covert.

Crack! The second whipper-in's thong rounds up the scattering hounds to the huntsman's horse. Slowly the cavalcade, headed by the huntsman and hounds, moves forward, the first whipper-in riding ahead to the right, the second whipper-in to the rear and left of the pack, or in any place where he may be wanted to keep a lagging or skulking hound in his place.

All round is gay, - men, horses, dogs,-

And in each smiling countenance appear

Fresh-blooming health and universal joy.

Following the hounds rides the Master, and to the right and left, and following on behind, the riders by twos and fours. Some drop back, others go forward to say a word 


\section{3 i 8 Cross Country with Horse and Hound}

to a friend, all rising and falling, falling and rising in their stirrups to the trot-toe-trot, trot-toe-trot, of their well-mannered steeds.

One pathetic exception is our friend who put his horse in a temper as he was mounting. He goes waltzing past the crowd with his horse in a lather less than a hundred rods from the meet. Pulling and sawing, tugging and pulling his poor horse only makes a bad matter worse; and all for the want of being one minute calmer in mounting.

More comfortable riders take this opportunity for looking about and counting up the riders - seventy-two in all, including several ladies - or gossiping a bit on the way.

Who is that driving past the riders with her horses in a gallop?

"Oh, that 's Mrs. So-and-So. She knows the country, and from the direction the hounds are taking she guesses the covert they are headed for. She always waits until the crowd is well on the way, then rushes past."

As a matter of fact, the lady asked the Master what covert he was going to draw first. It was a little comedy which did not escape a few of the knowing ones at the start.

"Well, really," replied the Master, in his politest manner, "you had better ask the huntsman."

Diverting her to the huntsman's track was a clever trick indeed, in which he was justified, because he knew the huntsman could cope with Mrs. So-and-So and her babbling tongue. She is particularly fond of being the first to whisper a matter to her intimates, and he is aware that by the time hounds reach the covert to be drawn, if she car- 


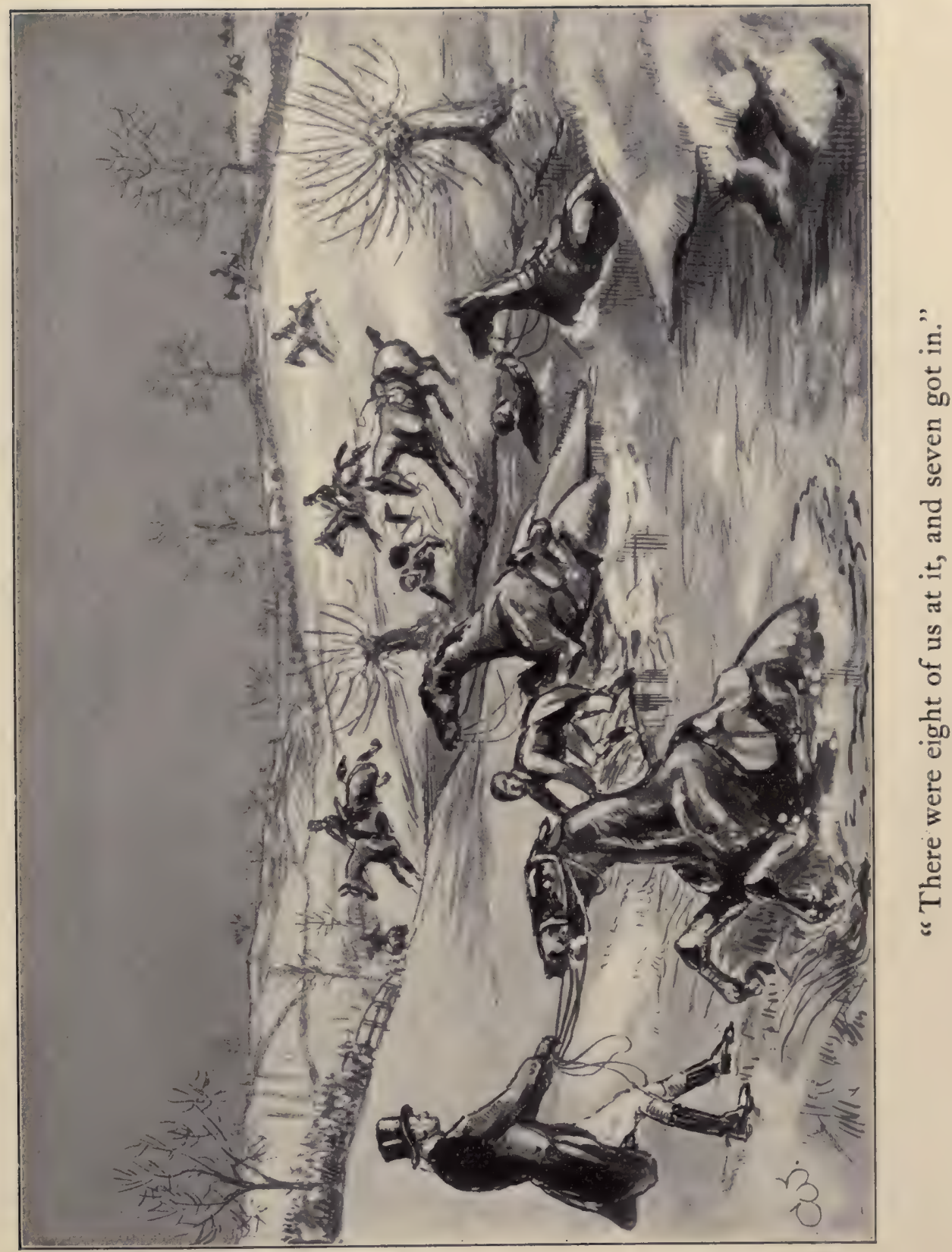



ries her point, half a dozen carriages and as many roadriders will have surrounded the wood in the best possible positions, as they think, to see the find and start, and will be sure to make the fox break covert before hounds reach there or can station themselves in a position to head him back.

Mrs. So-and-So, not being able herself to go to the huntsman, asked an unsophisticated gentleman, eager enough for a commission from the fashionable lady.

"Oh, Mr. Unsophisticated," she called to him. "You are just the man I 'm looking for. Would you mind doing me a favour?"

"Most happy, I assure you," answered the delighted gentleman. "Nothing could afford me-"

"Just go out and say to the huntsman, Mrs. So-and-So wishes to know as a special favour - as a special favour, mind - what covert is to be drawn first. There 's a good man. Never mind your hat."

“ Delighted to obey your orders, Madame," said Mr. U., with an impressive bow. Then, later, to a farmer on the edge of the circle, he said timidly, afraid to go in among the hounds, "I should like to speak to the huntsman."

"Go right up to him, stranger. The hounds won't hurt you," advised the farmer, knowing well what would happen.

The messenger ventured in, but no sooner had he entered an opening than the hounds surrounded him. First one and then another poked a cold nose against his hand, which jerked back as if it had touched a red-hot coal. Other hounds, seeing a man throwing up his hands, thought they 


\section{Cross Country with Horse and Hound}

were all to be rewarded with bread-crumbs, as the custom is at the kennels when visitors call. Poor Mr. Unsophisticated, unable either to go forward or go back, began to dance and jump and gesticulate like one shooing a flock of chickens. Everybody was soon laughing at the strange figure he cut. Finally, upon the whippers-in coming to his rescue, the hounds broke away, and the poor fellow managed to work his way out, though his mission was yet unaccomplished. He now made bold to deliver his message to the huntsman from the circle, to the renewed amusement of everybody.

"Really," was all the satisfaction he got out of the huntsman, who had been caught with such chaff before, "I have not consulted the Master about it yet this morning."

Thereupon the unsuccessful mercury rushed away to the house amid shouts of laughter from the country people, whose enjoyment of the city fellow's experience was unconcealed. The huntsman's "yet this morning" saved his reputation for the truth and pleased them hugely. It was indeed a close shave, as one who was present at the consultation of war will recall.

So Mrs. So-and-So, foiled again, waits until she sees the direction hounds are taking, and rushes away past all the riders, her horses on a run. Seeing this, the Master rides alongside of the huntsman and says: "Try no covert where drivers or townspeople are assembled."

This may upset all the well-laid plans of the night before. Fox-hunting, as we have shown, is a game of plot and counter-plot. The huntsman, a passed master in his art, decides on a ruse that sends Mrs. So-and-So, and a dozen 


\section{Riding to Covert}

others who follow her supposed leadership, to the Maple Grove covert; then, like a fox, he turns short back to the Benson wood, and draws the covert as originally planned. Master and huntsman exchange knowing smiles as they meet again.

A little before the Benson wood is reached, the huntsman nods to the first whipper-in, who by a circuitous route rushes off to take up his position on the side of the covert opposite that on which it is to be drawn. His duty there, as we have already shown, is to view the fox away.

At this point we can easily imagine the novice, who has doubtless heard a deal of talk among riding men about taking up the best position at the covert-side, asking where he had better station himself. We have already shown that foxes seek their food at night and sleep during the day. They usually kennel early in the morning, selecting the south or sunny exposure of the covert. But, since circumstances alter cases, should there be a breeze stirring at the time, they are likely to lie up for the day on the windward side, especially if they have reason to suspect danger from that direction. Their personal comfort, in other words, gives way to personal safety. Again, they may ignore both wind and comfort, and kennel on the side of the covert which is toward a farm-house where a dog is owned. Foxes must do their own picket duty, and seem to manage things so they may do this as much as possible while they sleep, relying more on their wits and cunning to get them out of harm's way, when they are warned of it, than on seeking some secure and secluded spot in the heart of a forest. If there is reason to believe a fox is to be found on the 


\section{Cross Country with Horse and Hound}

south side of a covert, most huntsmen prefer to cast the hounds in from the east or north or west, and hunt up to him, giving him the least opportunity to dodge or hang about before taking to the open. All this is a matter of woodcraft, and the problem, one of the interesting moves of the game, must be studied out by each rider for himself.

In approaching our covert to-day we notice that we do so from the east, and that the wind is south. We are, that is to say, starting with the general rule that the fox will be found on the sunny side of the covert, and that since his nature is to travel up-wind he will in this case break toward the southward if the hounds are in the east to help him decide. We cannot stop now to discuss the numerous other complications which may arise. The Master may prefer, for instance, on account of the condition of the fields to the south of the covert, to send the fox the other way out. Assuming that everything is favourable, however, to the fox's breaking south, our best station to get away with a good start will be at the southeast corner. At the same time we must be careful not to go beyond the corner, or we may head the fox back into the covert again, which is a thing no hunting man should ever be guilty of. Novice had better not make too great an advance in that direction, for the Master, who is himself setting the example of holding back, has an eye on all the forward riders, and a step too far is sure to bring a reprimand. "Hold hard there, Bayhorse! Hold hard! Do you want to head the fox back to the covert ?"

We had better keep back, taking a position a very little in advance of the Master himself; we must remember, as he 


\section{Riding to Covert}

does, that foxes do not always kennel on the south side or go away up-wind. Sometimes, indeed, it seems as if they knew the general theory of hunting men in this regard and kennelled for the day in a position to upset all their well-laid plans. Position is really something that concerns the hard riders more than it does the genuine hunting men. When you get it right it is considered a great stroke of luck, and when, as is often the case, you don't it is very hard indeed.

The question of right position is an easier one after the fox has broken. After the first burst of speed, lasting, according to the condition of the fox, for five or twenty-five or even forty minutes, there is sure to be a check, and then, as we have shown, he turns down-wind. For instance, he goes away east and the wind is south. Then he is almost certain to turn to the north, so as to run down-wind, and if you wish to take advantage of him, your best position will be to the north of his line. For my own part, I prefer to take no position in advance of the Master at the covert-side, and to follow the hounds, if I can, regardless of wind. Should they get out of sight or hearing when going east, for instance, the wind being south, I keep to the north country, so as to have a ready view of them if they make a turn that way themselves. For a hunting man this is quite enough manœuvring. A great many times, too, riding men would be better off if they did not undertake to anticipate the fox. But here we are at the covert-side. 


\section{XXIX}

THE GAME ITSELF 
"see, where they spread And range around, and dash the glitt'ring dew. If some stanch hound, with his authentic voice, Avow the recent trail, the jostling tribe Attend his call, then with one mutual cry The welcome news confirm, and echoing hills Repeat the pleasing tale." 


\section{XXIX}

\section{THE GAME ITSELF}

\section{BREAKING COVERT - FULL CRY - THE CHECK - THE RIDERS - THE DEATH}

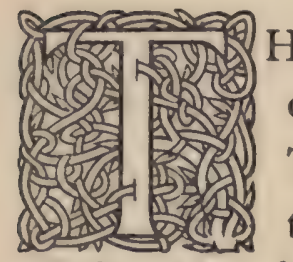

HE huntsman, without a moment's delay, casts the hounds into the covert with a cheer. The whipper-in goes over the fence beside them, and the huntsman follows, whereupon all the riders halt or begin to move to the south, the east, or the northeast corner of the covert, according to their several judgments of the way the fox is likely to break, or their knowledge of the country. The thong of the whipper-in keeps up a lively cracking to prevent hounds from spreading too wide. The huntsman is cheering on the pack, encouraging it to draw.

"Edawick! Edawick! Edawick! Oust him! Away with him! Rouse him! Rouse him, my beauties!"

How the hounds fling and drive, now halting in a cluster with noses down and sterns waving, now scattering, now on again, making good every yard of the way! Your blood cannot help but tingle. Cigars and cigarettes are thrown away. Another hasty glance at curb-chain and throat- 


\section{Cross Country with Horse and Hound}

latch, a feeling of saddle-girths. Each horse has caught the spirit and is as eager as the riders for the challenge.

See, the chestnut veins are swelling;

In her neck the blood is welling!

Of what peculiar stuff must a man be made who is not stirred at such sights and sounds as these? It must be something of the nature of putty. Yet there sits a chap on a slab-sided, three-cornered rake of a thoroughbred, lighting another cigarette and looking, or assuming to look, as if the whole proceedings were a bore. $\mathrm{He}$ is talking to another "chappy," telling him the latest morsel of gossip from the club, probably, to show his indifference to the game. One likes to believe that such a mien generally is assumed, but it is not always. There are men who merely act this rôle, and there are others for whom the part of a drone is natural. The vacant, listless stare in the presence of such stirring sights and sounds as these makes a man look the idiot truly, creatures in whom our " higher" civilisation has bred out all the sporting instinct of their fathers, fellows who are out to ride, and "if it were not for the d- dogs could have some fun."

All the hunting types are here. Look at that man on the roan, shamelessly spurring his mount to make him jump and rear just to show off; and the "swell" on a chestnut, riding about among the crowd on the same errand. These are the peacocks of the hunt. Again, that alert, nervous chap on the black, edging his way to the southeast corner, is out to cut down the field; the horse he rides is a new 


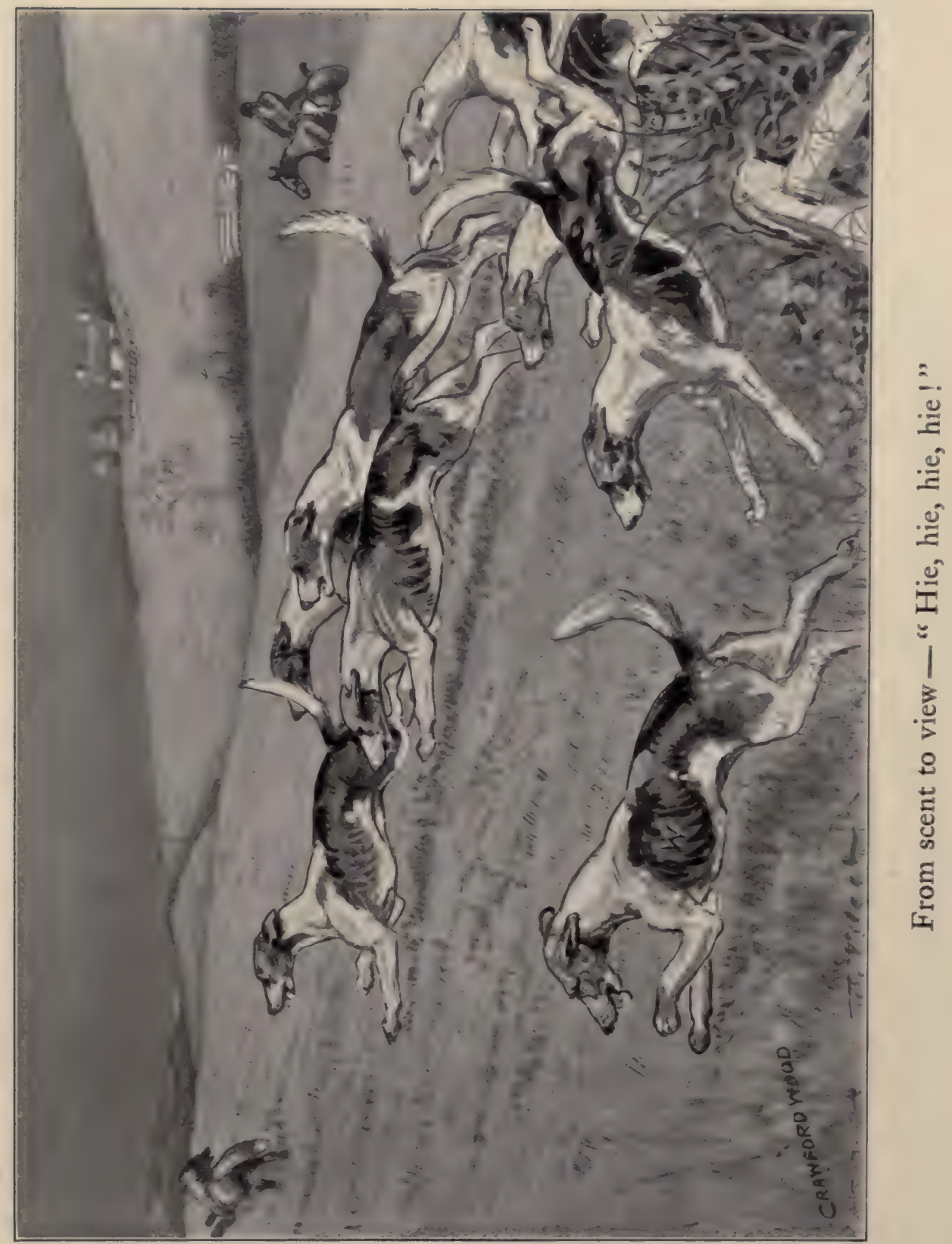





\section{The Game Itself}

one, a steeplechaser, just fast enough to be beaten between the flags; and he has it in for two or three fellow-riders, no doubt, who have been leading the field. They are what the Master calls "threshing scoundrels." Blackhorse keeps on, and as he moves forward others follow - there are always plenty to follow a foolish lead - till, just as we expected, out comes a scolding from the Master: "Hold hard there, Blackhorse! Hold hard, I say! I beg of you, gentlemen, give the fox a chance." They stop where they are. Now our Master, whom we saw all smiles and good cheer at the meet, is getting red in the face. He wishes to the bottom of his heart the fox would break north and leave these fellows hopelessly behind. Between you and me, dear reader, I think this is one reason why the huntsman does what he can to make foxes break in the direction unexpected by the hunting-to-ride men.

A third-rate horse-dealer who has timed himself just right comes dashing up. He has not come by way of the lane as all the other riders have, but jumps his horse into it, and, with a loud shout to some other rider, succeeds in calling every one's attention to his arrival. "What do you think of this one?" he inquires, loud enough for all to hear. "The best one I ever owned!"

Some late-comers and farmers join the group, the latter on "green uns" for their first introduction to hounds. They follow for a few miles where the leaders have knocked the top rails off, and then retire.

Meantime the hounds have hunted through the covert and are heard returning. Hark! A challenge!

$\mathrm{No}$; it is only a new-entry hound giving tongue to 


\section{Cross Country with Horse and Hound}

a rabbit and now getting a sound rating for his mistake from the whipper-in. He goes ki-yi-ing back, with a stinger from the whipper-in's crop that raises his hair.

The hunters shout;

The clanging horns swell their sweet-winding notes;

The pack, wide op'ning, load the trembling air

With various melody ; from tree to tree

The propagated cry redoubling bounds,

And wingèd zephyrs waft the floating joy

Thro' all the regions near.

Listen! A whimper.

"Speak to it!" cries the huntsman, as he sees his favourite feathering wildly. "Speak to it, Quickstep!"

But Quickstep will not tell a lie, no matter how much the huntsman encourages her. Hearing this cheer to Quickstep, several hounds rush to her side, Trumpeter among the others; but even that great-nosed hound cannot hit it off. They are most likely on the "drag" of the fox, that is, the line he took when he entered covert early in the morning on his way to kennel.

Then, cross-examining with curious nose

Each likely haunt - hark! on the drag I hear

Their doleful notes, preluding to the cry.

They push, they drive, while from his kennel there

The conscious villain, see, he sulks along.

Another whimper. "Speak to it, Bluebells! Speak to it!" cries the huntsman.

"Tally-ho, tally-ho! Gone away, gone away, gone 


\section{The Game Itself}

away!" shouts the first whipper-in from the west side of the covert. The great forest to the north repeats it in echo - "gone away, gone away - away!"

Hats are rammed down a degree tighter. Horses, like their riders, are hardly to be controlled. They rear and break away like race-horses at the starting-post.

"Hold hard, I say, gentlemen! You must hold hard!" bawls the Master. "Give the hounds a chance. I say, Blackhorse, look where you are going. Hounds are not running yet." The Master loses his temper, and a lecture is in pickle for some one. Have the blessed hounds gone to sleep, we wonder? How the minutes drag between the tally-ho gone away and the find!

Hark! a whimper - a challenge by Trumpeter, as we know by the deep guttural voice, confirmed by Bluebells. Half a dozen hounds rush to their sides. The huntsman, with cap in hand, leans over his horse's withers, cheering the hounds. "On, Bluebells! On, good bitch!" A little farther, and Quickstep, who has rushed ahead, as she always does, hits off the line, and, with one grand chorus that fills the forest with its melody, the whole pack goes streaming away like a flock of birds.

How low they stoop, And seem to plough the ground! Then, all at once, With greedy nostrils, snuff the fuming steam

That glads their flutt'ring hearts. As winds let loose Frorn the dark caverns of the blust'ring god, They burst away and sweep the dewy lawn.

The welkin rings; men, dogs, hills, rocks, and woods In the full concert join. 


\section{Cross Country with Horse and Hound}

The chase is on. "Now, lads, ride!"

Is n't it glorious, this first burst of speed on a horse that is just a little above himself? No pen can ever hope to describe it. It is as if the gods had given you wings. Hear the clamorous pack leading on, your horse scarcely touching the turf as he races away, eager in pursuit. The first few fences make us catch our breath, for our mounts will take them flying, clearing them with feet instead of inches to spare. Yet we must not, even in this moment of exultation, forget our horsemanship. Allow no horse to take liberties after the first fence or two. It is all very well to let him rid himself of the superfluous kinks in his legs and back and his surcharge of energy, rather than set up a fight or ruffle his temper, but on no account must he be permitted to shoot his bolt.

"What, a check so soon?"

Yes, and very welcome. Let us stop where we are. If it be a short turn back we are well enough where we stand, or if the fox has already turned down-wind we could not be in a better position. In that case the hounds have only overshot the line and must come back to find it. Let us dismount after the hounds have been permitted to make their own cast and have failed. We must keep an eye to them, however, and at the first symptoms of a whimper be ready to mount.

Now the huntsman, seeing that the hounds do not find the scent again by their own cast, lifts them smartly upwind, and, failing there, wheels them around down-wind with a wide cast back; and, sure enough, the leading hounds begin to raise their hackles and wave their sterns. The 
deep-tongued Vagabond hits off the line, raises his head, and gives a great shout. A dozen hounds rush past him, and once more the distant woods reëcho the joyous notes of horn and hound. Away we go again. Now we have settled down to business. There must be no more nonsense now; not an ounce more of exertion than is absolutely necessary must be taken from our horses. Steady, now, to this first fence! Take him well in hand from now on. It is a question not so much of fast riding as of horsemanship. That's it! Slow him down nearly to a trot. It's a high fence, and he no longer jumps higher than is necessary. Good! Well over, Novice. Yet not so with every one. There is a great smashing of top rails, and four riderless horses go racing away in the next field. Nobody is hurt, luckily. One fellow has his silk hat knocked into an accordion down over his ears and eyes, and is trying with both hands to extricate himself from under it. Another is chasing along across the field afoot, feeling very cheap indeed, like a fellow running after an express-train. Another, whose white hunting-breeches have turned green, is staring wildly about as if he were just recovering his senses, not knowing whether he is awake or dreaming. Another has crawled up on the fence, and sits there, digging the grass and dirt out of his neck and ears, while he trusts to some one else to catch his horse for him.

Four horses were seen in a terrible plight;

Four riders were all more or less in a fright.

At this juncture comes a check again. Now Renard has in all probability turned, after a rest, and is headed for 


\section{Cross Country with Horse and Hound}

the point he first planned to make before he broke covert. In this case the check may be short, and we had better remain mounted until we see how the hounds act. The huntsman is hardly giving them time to make their own cast; he is certainly in possession of some knowledge as to Renard's game. Directly back he lifts them, and away they go again over some good-scenting grass-fields.

The chorus swells; less various, less sweet

The thrilling notes when in those very groves

The feather'd choristers salute the spring,

And every bush in concert joins, or when

The master hand in modulated awe

Bids the loud organ breathe, and all the pow'rs

Of music in one instrument combine,

An universal minstrelsy.

So steady your horse again, and keep as much in reserve as you possibly can. Only keep the hounds in sight. They are the only pilot - unless you are a stranger in the country - worth looking after. What, a brook? Now, then, Novice, not too fast! Steady to within the last few strides, and hold him well in hand for a swerve or refusal. Good enough! You see, the energy you have been saving in your horse stood him in well, and he cleared it with ease.

Check again. Splash! Splash! Co-souze! - go half a dozen riders into the brook. Every man of them raced at it from twenty or thirty rods back.

There were eight of us at it, and seven got in.

What a sight! One fellow is standing on the landing-side, trying to pull his horse up by the bridle-reins. Another 
rider stands dripping on the bank, while his horse is going back the way he came. Another is off his horse and up to his shoulders, wading in the stream, his hat floating away on the current. Still another's horse braced his feet and bolted on the bank, sending his rider head first into the brook, like a boy from a spring-board.

In the meantime hounds have hit off the line again, and away we go down-wind. Renard has come to the conclusion that, plan or no plan, the thing for him to do is to save his brush. Now he will go down-wind only so far as to keep the hounds in hearing. The end is nearing. The older hounds are driving to the front. Now is the time for one to ride. Now comes the trying time, for when Renard is nearly beaten then his cunning and craft are brightest.

A check? No-yes! All but three hounds. Not a moment is to be lost. Now must the huntsman ride! A sinking fox and a dying scent are before him. He urges forward, leaving the whippers-in to come on with the pack. Check again. The pack overtake the huntsman. Trumpeter - where is Trumpeter? Bless that hound! He has hit off the line with a short turn to the right. There goes our fox, trailing his brush across yonder knoll. Now, lads, ride! One more field! "Hie! Hie! Hie!" shouts every one, galloping over the knoll and down a gradual slope. The fox is in one field, the hounds in the next, and the riders that are left in the third. "Hie! Hie! Hie!"

Can Renard make his point, which seems to be a covert several fields farther on? On, hounds! That covert contains an open earth. Our horses can no longer answer to 


\section{Cross Country with Horse and Hound}

whip or spur. Still we are gaining. Quickstep is not a rod behind Renard's brush. "Hie! Hie! Hie!" shouts every rider, in one mighty effort and final rally to hounds and horse. "Whoop! whoop!" as the prowling chickenthief rolls over in the opening.

The huntsman jumps off his horse, takes the fox from the hounds, and pockets the masks, pads, and brush. Then, with a tooting of his horn, he calls the stray hounds and riders in, and with " He was a jolly good fellow!" Renard's carcass is thrown high in the air, to light in the centre of the snapping, snarling pack. "Break him, my beauties, break him!"

Meantime riders have dismounted. Some have thrown themselves full length on the grass. Like their horses, they are done to a turn. For you and me, Novice, let us ease our saddle-girths and lead our mounts to a knoll where they can get the refreshing air, while we tell them they are the best in the stable, or at least give them some worthy compliment on their endurance.

A lady rider, Miss Frances, whom we met at the meet, is presented with the brush. Mr. Arthur, among others, rides up to congratulate her, and the two ride off together. The mask goes to a visiting gentleman from Boston. Novice receives a pad. His friends surround him and "blood" his face with it in due and ancient form.

And now we trot toward home in the wake of the hounds, tired, but as happy as we are tired - all except the jealous riders who have been cut out by Blackhorse. The steeplechaser lately imported on the quiet from Canada has done the job. Blackhorse, to be sure, is very fond of 


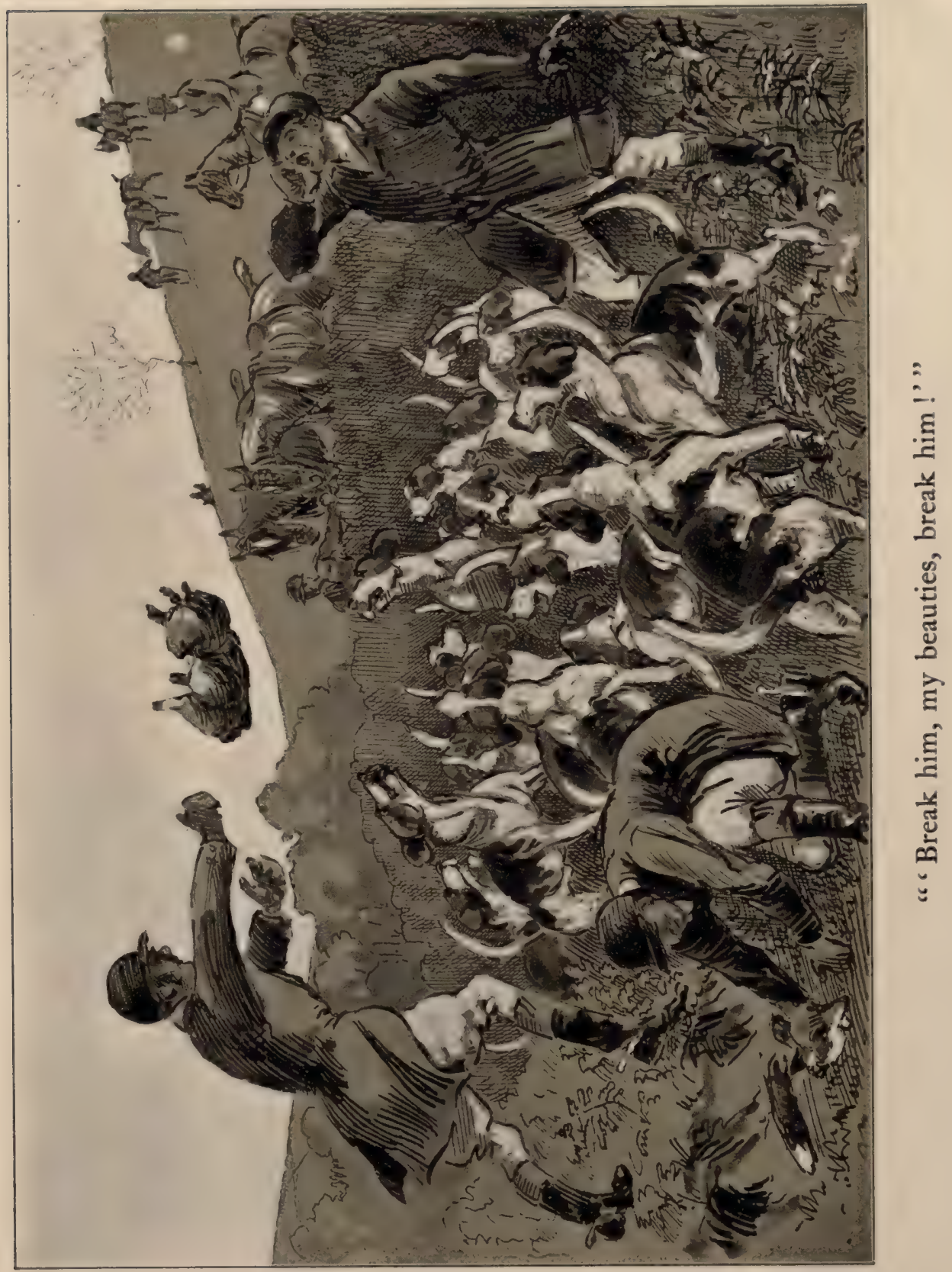





\section{The Game Itself}

himself, but the four or five others whom he left behind are wretched. So much to heart has one of them taken his defeat that he declares " if he carn't buy something to beat Blackhorse he will never come hunting again." On the way home there is little to talk about; only the horsedealer seems able to keep his tongue going. Home at last, our horse has a pail of warm oatmeal gruel, which we give him with our own hands. We see him done up for the night to our liking before we hasten in to dress for the dinner the Master is giving at the club in honour of the huntsman, whose birthday it is, and some other visiting knights of the pigskin. We must not miss it, for it is sure to hold something good in store. 



\section{XXX}

\section{THE HUNT DINNER}


" Whatever our fate, may every one say

There is nothing like hunting on a good scenting day." TO FOX-HUNTING 


\title{
XXX
}

\section{THE HUNT DINNER}

THE HUNTSMAN'S TOAST - "TO FOX-HUNTING IN GENERAL" THE DOCTOR TELLS A STORY

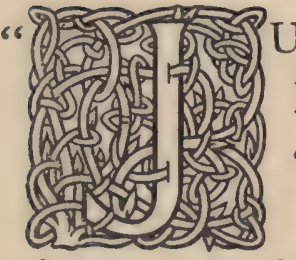

a few congenial spirits," says our Master, on the way home from covert; "no formality."

Hunting men at dinner, like hounds when the pace is fastest, give little or no tongue. But by the time cigars and cigarettes are passed they become such a set of babblers as would "draft" the lot of them without more ado. Over and over again they discuss the run of the day, straight, crossways, and then "catacorner," as the farmers say they cultivate their corn. Like the corn, that grows taller and broader for each cultivation, so grow the fences higher and the brook wider at least a foot at every telling. The brook is no longer a creek, but a canal, to those who have tasted it, a river to those who forded it. Each hunter's vices have become trivial faults, his faults mere eccentricities which only amuse and delight. His mistakes we gladly take upon ourselves, where, in all probability, they belong. So the babblers babble on till finally there is a stir at the Master's end of the table.
\end{abstract}




\section{Cross Country with Horse and Hound}

"Gentlemen!" says the Master, rising, "gentlemen, this is our huntsman's birthday. I suppose he has forgotten the fact entirely. I have asked you to come this evening to remind him of it."

Then, after some complimentary remarks on our huntsman's skill, his health is drunk to the tune of " $\mathrm{He}$ 's a jolly good fellow!"

Here 's to our huntsman, so cheery and keen!

To all of his breed, whether scarlet or green!

To the hounds! And may never their progeny fail

To go like their sires of to-day in the vale.

Our huntsman, looking as shy as a new-entry puppy, stands up, and, after a few words of thanks to the Master and of general compliment to the hunt, he proposes the following toast:

TO FOX-HUNTING IN GENERAL

May we find a good horse who is fond of the play;

May our foxes be straight-necked and show hounds the way;

May every one of us hear the glad gone away

As he stands near the covert on the best hunting day!

May the fences never stop us, nor the brooks cause dismay;

May our hounds never weary or their noses delay;

May hound music never cease through eternity to roll,

Cheering on every heart that is tuned to its toll.

Whatever our fate, may every one say

There is nothing like hunting on a good scenting day! 
At the end of this poem the Master rises again. "Gentlemen," he says, "we have with us to-night our old friend the Doctor, who takes his hunting in a carriage, but, for all that, usually sees as much of the game or more than the riders themselves.

To the poor he advice gives away;

For the rich he prescribes and takes pay.

But to each one he 's said,

'You will surely be dead

If you don't go a-hunting to-day!'

We saw him out to-day with a new entry whom he was introducing to hounds."

The Doctor is a very popular attaché of our hunt, as the reader may have surmised who followed him through the chapter on "Driving to Hounds." It is therefore amid a great tumult of applause and clinking of glasses that he stands up to reply. His full rounded form and face are so full of good humour that one of his friends declares the sight of him does his patients more good than all the pills and herbs of his medicinal stores.

He pauses a moment for the applause to subside, then drops his head to survey the company over the top of his eye-glasses, while the crow's-feet begin to pucker at the corners of his eyes and his mouth begins to draw. His friends break out again in anticipated relish of what they feel sure is to come. After a few complimentary remarks befitting the celebration, and a sly allusion to Mrs. So-andSo's drive to the Maple Grove covert,- the occasion of another wild demonstration from the members and blushes 


\section{Cross Country with Horse and Hound}

of the deepest dye on the face of the huntsman,- the Doctor begins an account of what happened that day to the person whom the Master was pleased to call his " new entry":

"My friend, Mr. Bankclerk, whom most of you met or ran against to-day, was, as the Master has said, out to-day for the first time to hounds. I had prescribed hunting for him, as I do in most cases ["Hear, hear!"], especially for insomnia and nervous prostration. It has been rather hard medicine for young Bankclerk, but if he perseveres it will cure him; that is, providing, of course, it does not kill him.

"It was only yesterday morning that we were discussing the matter in my office when our liveryman dropped in to collect his bill. Without mentioning names, I may say, to distinguish him from the other liverymen of our town, that he occasionally rides to hounds. I have never seen him off a highway or out of a lane, myself, if there was a fence between it and him. He generally has a horse or two to sell or trade-he is never at all particular which, though of the two he prefers a trade; and to swop horses with a gypsy is his special delight. You all know whom I mean. He wears a waistcoat of a horse-blanket pattern, a leather watch-guard, a horse's head for a scarf-pin, and cuffbuttons to match. He wears boots and riding-breeches seven days in the week, and is without exception the horsiest man in the county. Indeed, he looks like a horse and smells like a horse-stable.

“'Well, Doctor,' began our liveryman, striking his favourite attitude - his legs spread, his back to the wall, and his thumbs in the arm-holes of his vest, the better to 
display the same, 'you say you were not out last Thursday. You missed a sight. I was on Rory O'More; and what a clipper he is, to be sure! Not a better hunter ever looked through a bridle. Well, sir, Rory and I left the whole field as if they were standing. The first I knew, I was alone with the hounds. The huntsman was shouting at me from several fields behind; but I had no time to bother with him or the Master or the rest of them chappies trailing on after. I was doing my darnedest to ease up a bit, like any other good Christian, but, my sakes! don't you make a mistake; when hounds run, Rory O'More is going with them. A fence stood up in front of us. Gee whiz! but it was a regular church. Yet Rory would have it, and, as I live, he cleared it without a tick; six foot three and three quarter inches, by actual measure. I see we were in for a real buster, and, oh, Lord! another fence with a drop of ten feet on the landing-side. I roasted Rory one with my crop, and darn my eyes if he did n't take it in his stride. Well, that fence stopped the field, and when I had gone on and killed our fox, and done the obsequies in the best of style, who should come riding up but the Master and huntsman. The way they stared at me, you would have thought they had seen a ghost. What a wonder that Rory O'More is! I say, Doctor, you don't know of any one that wants to buy the best hunter in the United States cheap as bullock beef, do you ?'

"Well," continued the Doctor, "I saw there was going to be no end of it, and as our liveryman had forgotten to say what he came after, I said I must go. Imagine my surprise when I met Bankclerk, that evening, to learn that 


\section{Cross Country with Horse and Hound}

he had bought Rory O'More and was going to come out to-day for the first time. 'Well,' said I to my wife this morning, 'my patients must die or get well as best they can to-day without me. I 'm going to see the fun.' So I hung the slate on the door and started. Bankclerk sent his horse on by a groom, and rode over with me. 'Was n't it a fortunate occurrence that I happened to secure Rory O'More?' said he. 'I am going to rename him Romeo, after one of Shakespeare's characters; or would you call him something else? I lay awake half the night thinking up a name.' 'Perhaps one will suggest itself somehow before the day is over,' I replied; and so it did. 'Is he sound?' I asked.

"“Sound! Why, the dealer said he had n't a pimple on him.'

" And his wind?"

" "Well, I did say I thought he breathed rather hard, but the dealer seemed very honest about it; he said that showed the strength of his lungs.'

"“What did he say about his fencing?"

"“ "Well, you heard yourself what he said about how he could jump. "Jump! He will jump anything," said he, " that I would ever ask him to." Of course I don't expect,' added Bankclerk, 'that I shall take any such jumps as the dealer did until I am a little more accustomed to riding. However, you can understand I did n't want a green horse to begin with, and I hope to learn some things from Rory. The dealer said I surely would, as the horse knew it all.'

" "How did the dealer say he happened to be able to sell such a remarkable horse so cheap?' I inquired. 
"'He was owned by a gentleman who was going abroad. Sold for no fault of his own.' This I knew to be quite true, as the liveryman had taken the horse in a trade from a gypsy. 'Gentleman going abroad' - that point at least was not to be disputed.

" 'Sold for no fault of his own.'

"“Whose own?' I asked. 'The horse's or the former owner's?' But this seemed to make my good friend huffy, and I desisted.

"Well, I had to laugh to see Bankclerk admiring himself in the shop-windows as you rode through town to covert. " 'Why don't you carry a looking-glass in front of you?" shouted a boot-black at him as he passed. 'It would save the trouble of turning your head.'

"Before we reached the covert, Bankclerk was quilting away at his nag to make him keep up.

" 'Not much on the trot,' I suggested, ' is he? Give him the spurs.' This Bankclerk did, but Rory simply switched his tail and plodded on.

“" Come up, my beauty,' said Bankclerk, trying to get his old stager into a canter; for I could see my friend's back teeth were being loosened from the jolting of the old fellow's trot.

“'Come up, my beauty! Come along, my pet!' he cried, pushing on the lines and then pulling back as a signal for Rory to go ahead. And then, losing patience, he drove both spurs home with 'Get out of this, you lumbering idiot?' Thus addressed, Rory O'More broke into a bone-setting canter. The ring of his feet on the stone pavement could be heard for a mile. 


\section{Cross Country with Horse and Hound}

"Arriving at covert, I lost sight of my friend; but seeing the way hounds were running, I drove on. The next thing I saw of him he was about to jump a fence not over three feet high. He was leading the field, to be sure. Rory O'More got both fore feet over, and there he stuck. Forty riders behind were waiting their turn to go through the only gap.

" 'Have you a lease of the place for a term of years, or only for the day?' asked some one.

“" 'Build a fire under him,' cried another.

“' 'Pour water in his ears,' etc., until finally Rory O'More, having secured his second wind while resting on the fence, answered to my friend's quilting and went away with surprising speed.

"Later in the afternoon, whom should I see but Bankclerk come walking along toward the road. I waited for him. He was the picture of woe. His hat was knocked in so he looked like a Bowery tough; his new hunting-breeches were green as grass could make them on one knee, and torn to shreds on the other; his hunting-coat was a mixture of grass- and fallow-stains; and altogether he was the most forlorn-looking object I ever beheld.

"“Where is your horse? What has become of Romeo?" $I$ inquired.

"'Gone to the devil, I hope,' said Bankclerk.

" 'And your hunting-crop?' I asked.

"My friend, now that he was reminded of it, just missed it. He looked first at one hand, then at the other; then he felt on the outside of his pockets.

" 'Your hunting-crop,' I said. 'Have you lost it?' 


\section{The Hunt Dinner}

" 'The Lord only knows,' was the melancholy answer. " "Are n't you going to look for your horse?" I asked next, but still with no answer.

“ Ignoring the apparent absence of my patient's mind, I hastened to inquire if he had had an enjoyable day's sport. 'You certainly bear evidence,' said I, ' of having had a glorious day.'

" 'I never met such a beastly lot of blackguards in all my life.'

“' Come, get into my waggon and tell me all about it,' I said soothingly.

“" Well, to begin with,' said my friend, 'the Master swore at me awfully. I was n't doing anything, either. He rode up to me and said, "Why don't you hold hard when I ask you?" "Well, now, really," said I, "were you talking to me? My name is Bankclerk." And he wheeled his horse about and rode away saying he had no time to make me a set of brains. I thought when I heard him yelling "Hold hard, there, Greyhorse," what a funny name that was for a man. It seemed to make every one laugh that heard it. The next ruffian to ride up to me with another bucket of abuse was the huntsman. "What in - are you hollering at?" said he. "At the fox," said I; "just saw him run back in the woods, there. I thought you would be glad to know of it, and I hollered." With that he ripped out a torrent of abuse. "What are you doing here, anyway?" he asked.

“"“My name is Bankclerk," said I. "Dr. Nadvised me to go hunting for my health." "He should have given you rough-on-rats," said the huntsman. "Bank- 


\section{$35^{\circ}$ Cross Country with Horse and Hound}

clerk, did you say your name was?" “Yes, sir, from Rochester," said I. "May I give you my card ?” “Don't trouble yourself," said he. "You take my advice, young man: go home and have the cashier lock you in a safe and give him a dollar to lose the key." Nice way to treat a stranger, was n't it? Well, we came to a check, as you call it,' continued my friend, getting more and more indignant at the recollection of the treatment he had received, 'when I noticed a fellow standing apart from the rest of the company, looking about as lonesome as I was. So I rode up behind him, and by way of being civil I was about to ask him if it was customary for certain members of the hunt to tie red ribbons in their horses' tails, when his brute of a horse let fly with both hind legs and caught me on the knee. Look how he tore my breeches. Then the rider, too, turned on me and began to swear. "Can't you see where you are going?" he cried.'

"I explained to my friend that the red ribbon in a horse's tail was a sign he was a kicker.

“' Well,' said Bankclerk, 'why did n't he say so? Look here, Doctor,' he went on, 'you advised me to go hunting for my health. I have been within an ace of being killed at least half a dozen times in the last two hours. Your treatment is too heroic for me.'

"“ Well, what next?' I inquired, for I wanted to know how it happened he had lost his horse.

" "Let me see. Oh, yes; the next thing that happened, I got hung up on the fence, as you saw, and heard insulting remarks from the field. Then a fellow I was following my horse goes better, I find, if he has a lead-well, the 
horse ahead of me refused, and of course I bumped into him, and the rider fell off. When he got up he also began to abuse me like a pirate. "What do you mean by riding in my pocket?" he roared. "How did I know your old bloke of a horse was going to refuse?" said I.

" "Then I thought I would keep away from every one as a sure guarantee of not getting into any more rows, for you may be sure I had experienced quite enough of it by this time; so I went through a gate, and was crossing a field all by myself when I heard some galoot shouting, "Ware wheat, ware wheat!" and I saw an old hayseed of a farmer running after me. This was a little too much. I pulled up. " Now see here," said I. "What the — do you mean by shouting at me like this? What the are you hollering at, you fool? Go lock yourself in the barn and hire some one to lose the key," said I, just to give this impudent fellow the same treatment every one had been giving me. I had been insulted by everybody, from Master to stable-boys, and my monkey was up, I can assure you. "Ware wheat!" shouted the hayseed. "Wear it yourself," I replied.

" " "Get off the wheat!" he shouted. This jarred me, for I was in a ploughed field and not on the wheat at all. "I 'll not go until I get ready," said I. Then the old cuss came for me with a pitchfork. I turned my horse to go out of the field, with the farmer after me, clubbing and prodding my horse with the pitchfork. The going was deep, and my old nag had to take it at every jump. In clearing the fence into the woods he jumped so high that I was caught by a limb and knocked off. "Good 


\section{Cross Country with Horse and Hound}

enough for you!" said the farmer. "If you ever step foot on my land again I 'll prosecute you." I must have left my crop by his fence.'

" ' Go and look for it.'

" "Not much! And where the deuce that old plug of a horse has gone to I don't know, and, what 's more, I don't care. I paid twenty-five dollars down on the brute. I 'll forget that, and telegraph the liveryman his horse is somewhere in the woods and at his risk.'

"We drove along a little farther," continued the Doctor, "to look for him. "Romeo, Romeo! wherefore art thou, Romeo?' Presently we came upon some of the riders. A boy was leading Romeo about, waiting for some one to claim him. I have heard since I came here to-night that the horse, although a clumsy old brute, is very clever at his fences, and that my friend could not make him go on because he was riding him on the curb instead of the snaffle. But he will make a sportsman yet," said the Doctor, "and I want to ask you all, gentlemen, as a special favour, to help put the young man right. You never can tell by the looks of a toad how far he can jump." 






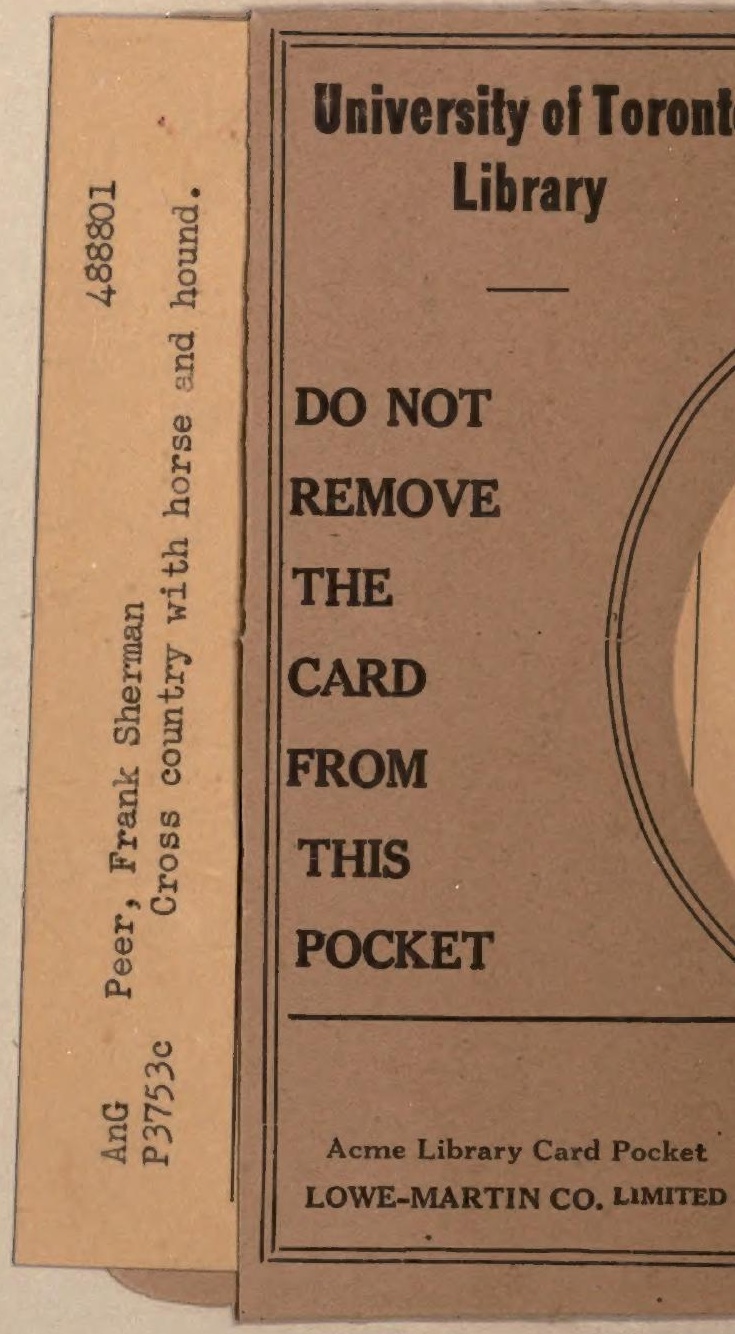


